\title{
Aspectos da transmissão de leishmanioses no Assentamento Guaicurus, Planalto da Bodoquena, Estado de Mato Grosso do Sul, Brasil, 2002-03. Infecção natural em animais domésticos e vetores.
}

\author{
Elisa San Martin Mouriz Savani
}

Tese apresentada ao Programa de Pós-Graduação em Saúde Pública da Faculdade de Saúde Pública da Universidade de São Paulo, para obtenção do título de Doutor em Saúde Pública.

Área de Concentração: Epidemiologia Orientadora: Prof ${ }^{\mathrm{a}}$ Dra. Eunice Aparecida Bianchi Galati

São Paulo
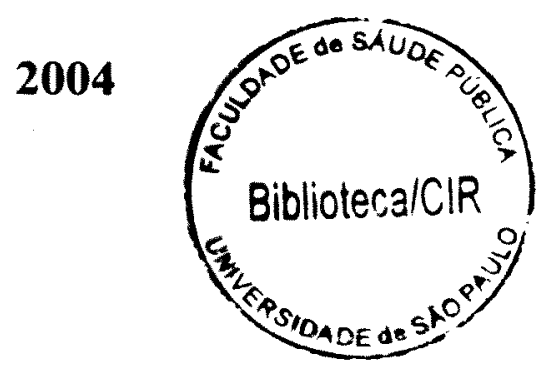


$$
45454 \mid 2005 \text { doe }
$$

Autorizo, exclusivamente para fins acadêmicos e científicos, a reprodução total ou parcial desta tese, por processos fotocopiadores. Ao usá-lo, cite a fonte.

Assin. .. э:

Data: 30 de agosto de 2004 
"Eu é que sei que pensamentos tenho a vosso respeito, diz o Senhor, pensamentos de paz, e não de mal, para vos dar o fim que desejais.

Então me invocareis, passareis a orar a mim, e eu vos ouvirei. Buscar-meeis, e me achareis, quando me buscardes de todo o vosso coração".

Jeremias 29: 11- 13 


\section{AGRADECIMENTOS}

Ao Senhor Jesus Cristo que abriu as portas, me capacitou, fortaleceu e me deu bom êxito em todas as etapas. Se não fora a Sua intervenção esta obra não teria sido realizada.

A Dra. Eunice Aparecida Bianchi Galati, pela orientação, amizade, colaboração e auxilio em todas as etapas do projeto.

A Dra. Vânia Lúcia Brandão Nunes da Universidade para o Desenvolvimento do Estado e da Região do Pantanal (UNIDERP), pela oportunidade de realizar este trabalho, pela execução dos trabalhos de campo e de laboratório de parasitologia, pela amizade e carinho.

A Dra. Lucile M. Flöeter Winter do ICB/USP pela orientação e colaboração, aos colegas Isabel Cristina Alves e Thiago M. Castilho pela supervisão e auxílio na execução das técnicas moleculares e ao Ricardo Andrade Zampieri, que sempre esclareceu dúvidas.

Ass amigas Marilene Fernandes de Almeida, Sandra Regina Nicoletti D'Auria, Maria Cecilia Gibrail de Oliveira Camargo pelo apoio, compreensão e colaboração em todas as etapas e ao Vagner Batista Alves pelo auxilio na preparação de todo material utilizado no campo e laboratório.

A amiga Maria Lúcia de Oliveira pela laboriosa montagem do banco de dados em computador para registro dos dados entomológicos e auxílio na confecção de tabelas e gráficos referentes a estes.

A todos os colegas do Laboratório de Zoonoses e Doenças transmitidas por Vetores que colaboraram direta ou indiretamente para realização deste trabalho.

Ao pesquisador Emilson Domingos da Silva do Instituto Bio-Manguinhos da Fundação Oswaldo Cruz pela doação de kits de ensaio imunoenzimático para leishmaniose canina.

Aos pesquisadores do Instituto Evandro Chagas em Belém - PA, Dr. Adelson de Souza pela doação de fêmeas de Lutzomyia longipalpis infectadas com Leishmania (L.) amazonensis e Dra. Edna Ishikawa pela identificação de cepa de protozoário. 
Aos moradores do Assentamento Guaicurus pela receptividade, colaboração e confiança. Em especial aos moradores dos lotes $02,19,20,35,59,60$, $102,110,115,124$ pela permissão para instalação de armadilhas para captura de insetos em suas propriedades.

Aos moradores e colaboradores do Assentamento Guaicurus na execução dos trabalhos de campo: Edna Maria da Silva, "Demo", Marilza e Jucilene Granjeiro Dias, Vivaldo Pedro Dias, Antenor Pedro da Silva, Ider e Iver da Silva.

Ao acadèmico de Medicina Veterinária da UNIDERP, Fernando Shiruma, pelos trabalhos de campo com os animais domésticos.

Ao meu amado esposo Júlio César e nossa família pela compreensão, companheirismo, auxilio, apoio e incentivo em todas as etapas do projeto.

A todos da familia Renascer em Cristo, em especial a presbítera Eliana, pelas oraçōes, apoio e compreensão. 


\section{RESUMO}

Savani ESMM. Aspectos da transmissão de leishmanioses no Assentamento Guaicurus, Planalto da Bodoquena, Estado de Mato Grosso do Sul, Brasil, 2002-2003. Infecção natural em animais domésticos e vetores. São Paulo; 2004. [Tese de Doutorado - Faculdade de Saúde Pública da USP].

Objetivo. No Estado de Mato Grosso do Sul (MS), como em outros estados brasileiros, a leishmaniose tegumentar americana (LTA) e a leishmaniose visceral americana (LVA) apresentam ampla distribuição geográfica. Estudos entomológicos e epidemiológicos realizados no Assentamento Guaicurus, municipio de Bonito, MS identificaram a presença de vetores de leishmanioses e a ocorrência de casos humanos de LTA e casos de LVA em cães. O presente trabalho, inserido em um projeto mais amplo que dá continuidade a esses estudos, teve por objetivo identificar a infecção natural por Leishmania em animais domésticos e vetores e ampliar o conhecimento sobre o comportamento da fauna flebotomínea, em ecossistemas do Assentamento Guaicurus e analisar esses encontros à luz dos fatores ambientais. Métodos. Foram examinados 53 eqüinos e 129 cães, dos quais se obtiveram amostras de sangue para a realização da reação de imunofluorescência indireta. As amostras de cães também foram submetidas ao ensaio imunoenzimático. Dos animais reagentes, foram colhidas amostras de aspirado medular para confecção de lâminas, tentativa de isolamento em meio de cultura, inoculação em hamster e realização da reação em cadeia da polimerase (PCR). Nesta última, também foram utilizadas amostras de creme leucocitário destes animais. A fauna flebotomínea foi pesquisada no período de outubro de 2002 a outubro de 
2003, realizando-se capturas quinzenais com armadilhas automáticas luminosas dotadas de inseticidas, instaladas em 25 pontos, distribuidos em áreas de mata, de cultivo, peridomiciliares e intradomiciliares e em uma gruta. Para a obtenção de fêmeas a serem dissecadas para a investigação da infecção natural por flagelados, mensalmente, eram feitas capturas com armadilhas de Shannon por dois ou três dias consecutivos, das 18h:00 às 22h:00 em alguns dos peridomicilios e foram instaladas armadilhas automáticas luminosas, sem inseticida, em vários ambientes do Assentamento Guaicurus. As fêmeas dissecadas, após identificação do flebotomíneo e investigação de flagelados sob microscopia, foram mantidas em álcool $70 \%$. Posteriormente, essas fêmeas foram submetidas à PCR para detecção de DNA do parasita e sua identificação por seqüenciamento. Resultados. Todos os eqüinos pesquisados apresentaram-se não reagentes. Entre os cães foi observado pela reação de imunofluorescência indireta, uma soro-prevalência de $15,5 \%(20 / 129)$ e $31,0 \%(40 / 129)$ pelo ensaio imunoenzimático. Dentre os cães reagentes, foi possível colher nova amostra de sangue de 28 animais e aspirado de medula óssea de 24 , sendo encontrados cães infectados por Leishmania (Leishmania) chagasi, Leishmania (Viannia) sp e Leishmania (L.) amazonensis. Em relação à fauna de flebotomíneos, foram capturados 19538 espécimes pertencentes a 15 espécies. Nas capturas quinzenais com armadilhas automáticas luminosas, com exceção da gruta, único ambiente onde Lutzomyia longipalpis não foi capturada e Lutzomyia almerioi predominou absolutamente, a primeira teve as suas freqüências mais elevadas em todos os ambientes, em ordem 
decrescente, mata, ambiente de cultivo, peridomicílio e intradomicilio, sempre seguida de Lu. almerioi e Nyssomyia whitmani. Lu. longipalpis e Ny. whitmani apresentaram densidades mais elevadas no verão e em julho e $L u$. almerioi somente no verão. Entre as 1395 fêmeas dissecadas, foram observadas ao microscópio, três de Lu. almerioi infectadas por flagelados. Pools de fêmeas dissecadas de Lu. almerioi, Lu. longipalpis e Ny. whitmani foram pesquisados por PCR, com 15 amostras positivas. Detectou-se a presença de DNA das três Leishmania, acima descritas em Lu. longipalpis e de Leishmania (L.) chagasi e de Leishmania (Viannia) sp em fêmeas de Lu. almerioi. Conclusões. A presença de cães e de fêmeas de flebotomíneos infectadas por L. (L.) chagasi, L. (L.) amazonensis e L. (Viannia) sp, são indicativos da transmissão de ambas as formas de leishmaniose, LTA e LVA na população canina, no Assentamento Guaicurus. Possivelmente, Lu. longipalpis e $L u$. almerioi atuem como vetoras, sendo o verão o período de maior risco para a transmissão, em virtude das densidades mais elevadas observadas nesta estação.

Descritores: Leishmanioses. Cães. Flebotomineos. PCR. Sorologia. 


\section{SUMMARY}

Savani ESMM. Aspects of leishmaniasis transmission in the Guaicurus Settlement, Bodoquena Planalto, Mato Grosso do Sul State, Brazil, 2002-2003. Natural infection in domestic animals and in sand fly vectors. São Paulo; 2004. [Doctoral thesis - Faculdade de Saúde Pública da USP].

Objective. In Mato Grosso do Sul State, as in other Brazilian States, American cutaneous leishmaniasis (ACL) and American Visceral leishmaniasis (AVL) are widespread. Entomological and epidemiological studies undertaken in the Guaicurus Settlement, Bonito county, have identified the presence of vectors and human cutaneous leishmaniasis and canine visceral leishmaniasis. This present project continuous those studies and has as its objectives the identification of natural infection by Leishmania in domestic animals and sand fly vectors, enhancement of our knowledge of the sand fly fauna of the ecosystems of the Guaicurus Settlement and analysis of the epidemiology of these parasite diseases in the light of the factors under investigation. Methods. Samples of blood were obtained from horses and dogs for analysis by the indirect immunofluorescent antibody test (IFAT). The dog samples were also submitted to the enzyme-linked immunosorbent assay (ELISA). Of the reagent dogs, samples of bone marrow aspirate were obtained for the preparation of slides, isolation in a culture medium, inoculation in hamsters and testing by the polymerase chain reaction (PCR). In this last, samples of the buffy coat of the animals were also used. The phlebotomine fauna was studied during the period from October 2002 to October 2003. Captures were undertaken fortnightly, with 
automatic light traps with insecticide in 25 points distributed in forested and cultivated areas, peridomiciliary and intradomiciliary environments and in a cave. Monthly captures were carried out with Shannon traps installed in some of the peridomiciles and automatic light traps, without insecticide, in several environments of the Guaicurus settlement for the investigation of natural infection by flagellates in sand fly females. The dissected females, after examined under the microscope to search for flagellates and identification of the phlebotomine, were conserved in alcohol $70 \%$ and submitted to the PCR to detect the presence of parasite DNA and identify it by sequencing. Results. None of the horses was reagent. For the dogs observed by IFAT, a seroprevalence of $15.5 \%(20 / 129)$ and $31,0 \%(40 / 129)$ was found by ELISA. Among the reagent dogs, a further sample of blood was taken from 28 animals and bone marrow aspirate from 24 of these, among the dogs some were found to be infected by Leishmania (Leishmania) chagasi, Leishmania (Viannia) sp and Leishmania (L.) amazonensis. As regards the phlebotomine fauna, 19,538 specimens belonging to 15 species were captured. In fortnightly captures with automatic light trap, except in the cave, the only environment in which no Lutzomyia longipalpis was captured and Lutzomyia almerioi predominated overwhelmingly, the former had higher frequencies in all the environments sampled, in decreasing order: forest, the cultivate areas, peridomicile and intradomicile, always followed by $L U$. almerioi and Nyssomyia whitmani. Lu. longipalpis and $\mathrm{Ny}$. whitmani present high densities during summer and in July and Lu. almerioi only in the summer. Of the 1,395 females dissected, three $\mathrm{Lu}$. almerioi were found 
under the microscope to be infected by flagellates. Pools of dissected females of Lu. almerioi, Lu. longipalpis and Ny. whitmani were investigated by PCR, presenting 15 positive samples. The presence of the DNA of the three above mentioned Leishmania was detected in Lu. longipalpis and Leishmania (L.) chagasi and Leishmania (Viannia) sp in females of Lu. almerioi. Conclusions. The presence of dogs and phlebotomine females infected by L. (L.) chagasi, L. (L.) amazonensis and L. (Viannia) sp, indicates the transmission of both forms of leishmaniasis, $A C L$ and $A V L$, in the canine population of the Guaicurus Settlement. Lu. Iongipalpis and Lu. almerioi possibly, act as vectors, summer being the periods of greatest of risk of transmission, in view of the higher densities presented in that season.

Key-words: Leishmaniasis. Dogs. Phlebotomine. PCR. Serology. 


\section{ÍNDICE}

1. INTRODUÇÃO

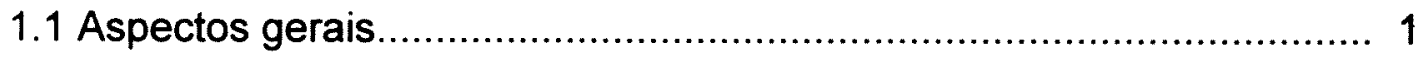

1.2 Leishmanioses no Brasil ................................................................. 4

1.3 As leishmanioses em Mato Grosso do Sul...................................... 9

1.4 Diagnostico das leishmanioses ..........................................................16

1.5 Infecção natural por Leishmania nos flebotomíneos ......................... 20

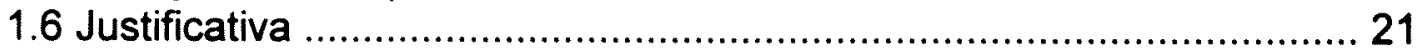

2. OBJETIVOS

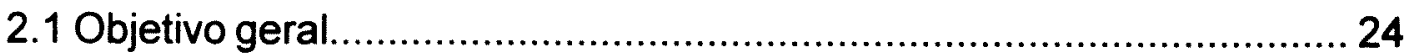

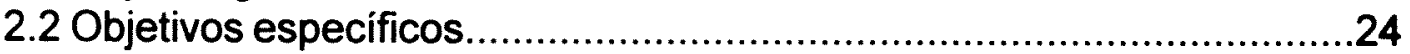

3. MATERIAL E MÉTODOS

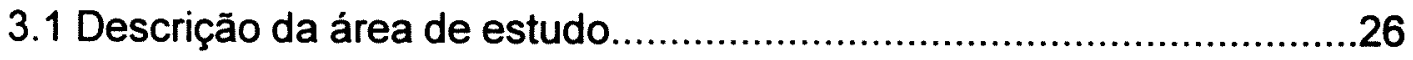

3.1.1 Aspectos gerais do Planalto da Bodoquena.............................. 26

3.1.2 Características locais do Assentamento Guaicurus..................... 28

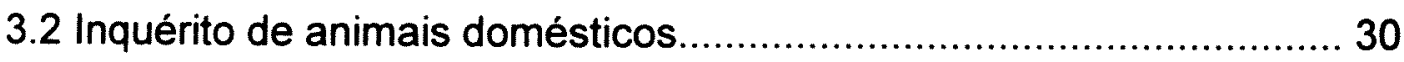

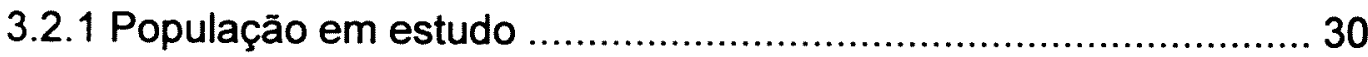

3.2.2 Colheita de sangue - primeira amostra ..................................... 31

3.2.3 Colheita de aspirado medular e segunda amostra de sangue .....32

3.2.4 Pesquisa de anticorpos anti-Leishmania .....................................33

3.2.4.1 Reação de imunofluorescência indireta ..................................33

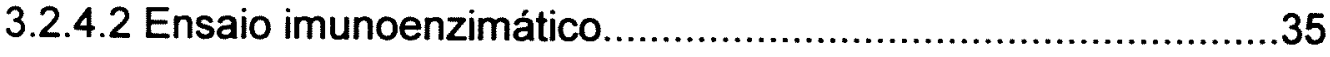

3.2.5 Pesquisa parasitológica de Leishmania .......................................36

3.2.6 Deteç̧ão molecular de Leishmania .......................................... 37

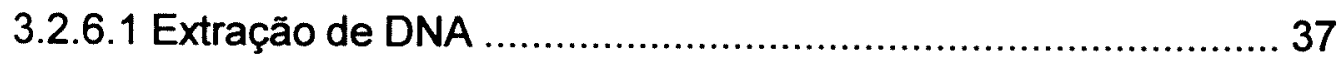


3.2.6.2 Reação em cadeia da polimerase.

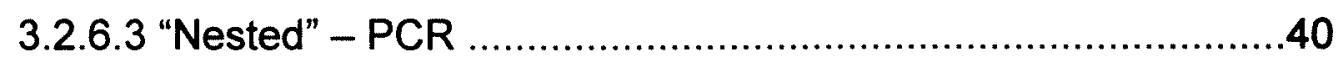

3.2.6.4 Purificação de produto de PCR ………………....................41

3.2.6.5 Seqüenciamento de DNA ...................................................

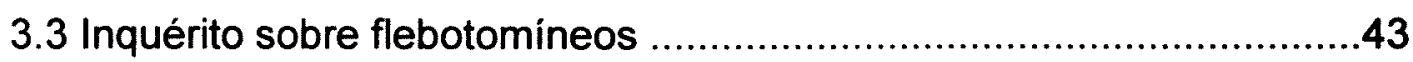

3.3.1 Capturas com armadilhas luminosas, tipo CDC, com inseticida ..43

3.3.2 Capturas com armadilhas tipo Shannon ....................................47

3.3.3 Capturas com armadilhas luminosas automáticas modificadas,

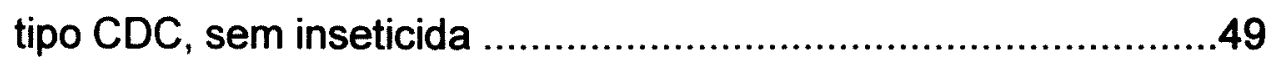

3.3.4 Investigação de infecção natural por Leishmania .........................52

3.3.5 Análise dos resultados entomológicos .....................................53

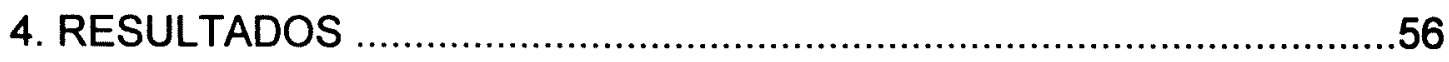

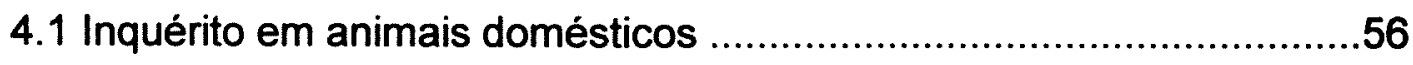

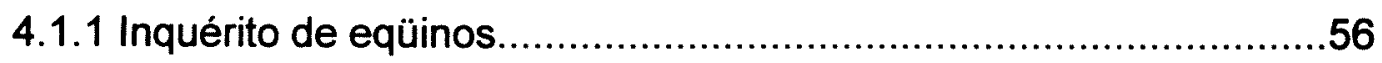

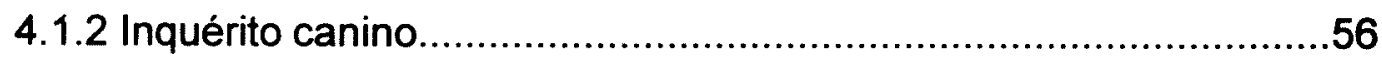

4.1.2.1 Prevalência de anticorpos anti-Leishmania ........................ 56

4.1.2.2 Investigação dos cães reagentes e inconclusivos .................59

4.1.2.2.1 Segunda amostra de soro e eluato sanguíneo ...............62

4.1.2.2.2 Ocorrência de co-infecção .............................................64

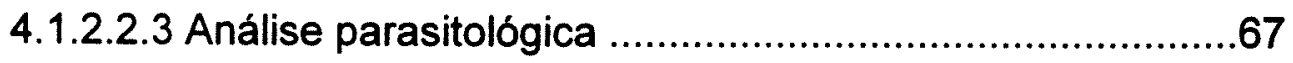

4.1.2.2.4 Análise molecular .....................................................67

4.1.2.2.5 Sintomatologia e reatividade dos cães infectados ..........71

4.2.Inquérito sobre a fauna flebotominea............................................... 73

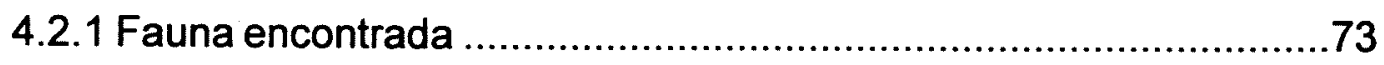

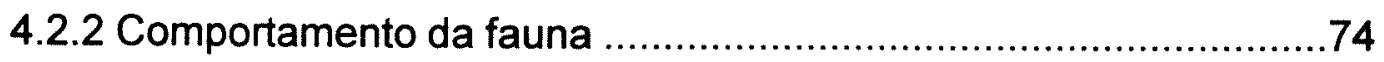




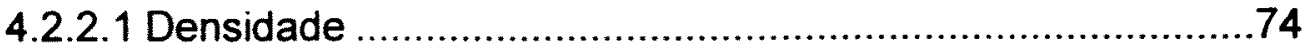

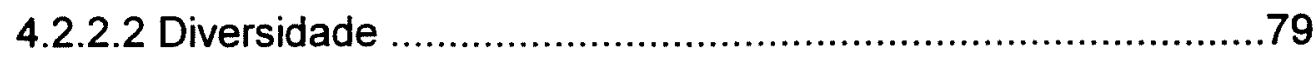

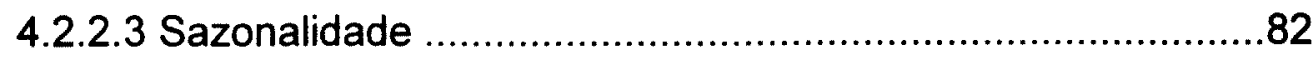

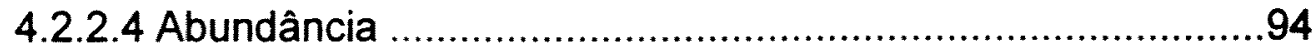

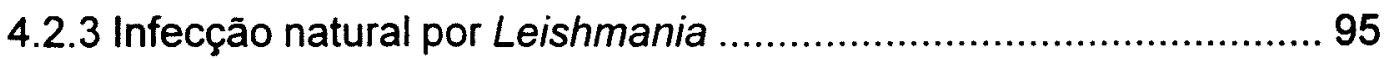

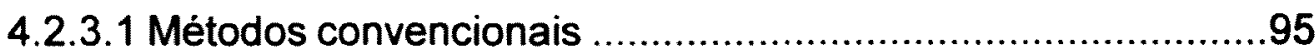

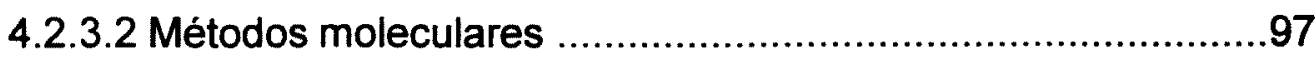

5. DISCUSSÃO

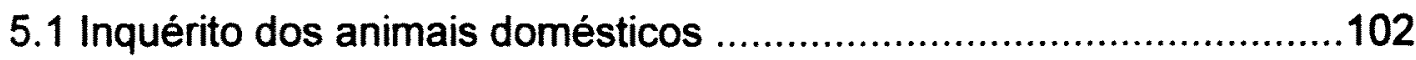

5.2 Inquérito sobre a fauna flebotomínea .......................................... 111

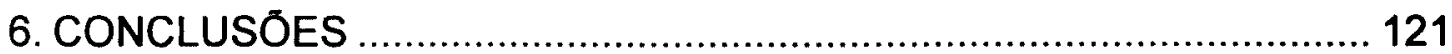

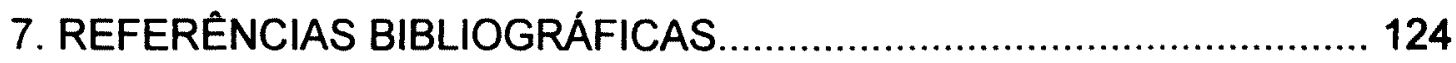

\begin{abstract}
ANEXOS
Anexo 1 - Parecer do Comitê de Ética em Pesquisa da Faculdade de Saúde Pública da Universidade de São Paulo sobre o protocolo de pesquisa.
\end{abstract}

Anexo 2 - Resultados da reação de imunofluorescência indireta (RIFI) e ensaio imunoenzimático (EIE) em amostras de soro e sangue em papel filtro dos cães do Assentamento Guaicurus, fevereiro e março de 2003.

Anexo 3 - Resultados da reação de imunofluorescência indireta (RIFI) e ensaio imunoenzimático (EIE) na segunda amostra de soro e sangue em papel filtro e manifestações clínicas dos cães do Assentamento Guaicurus, junho de 2003.

Anexo 4 - Resultados das PCR em aspirado de medula óssea e creme leucocitário e seqüenciamento, em cães do Assentamento Guaicurus, junho de 2003. 
Anexo 5 - Distribuição mensal das chuvas no Município de Bonito-MS, de abril de 2002 a outubro de 2003 , e da média mensal do período de 1981 a 2003.

Anexo 6 - Média de Williams para fêmeas de Lu. longipalpis por local da captura no Assentamento Guaicurus, novembro de 2002 a outubro de 2003.

Anexo 7 - Média de Williams para machos de Lu. longipalpis por local da captura no Assentamento Guaicurus, novembro de 2002 a outubro de 2003.

Anexo 8 - Média de Williams para fêmeas de Lu. almerioi por local da captura no Assentamento Guaicurus, novembro de 2002 a outubro de 2003.

Anexo 9 - Média de Williams para machos de Lu. almerioi por local da captura no Assentamento Guaicurus, novembro de 2002 a outubro de 2003.

Anexo 10 - Média de Williams para fêmeas de $N y$. whitmani por local da captura no Assentamento Guaicurus, novembro de 2002 a outubro de 2003.

Anexo 11 - Média de Williams para machos de Ny. whitmani por local da captura no Assentamento Guaicurus, novembro de 2002 a outubro de 2003. 


\section{RELAÇĀO DAS FIGURAS}

Figura 1 - Localização do Assentamento Guaicurus no Planalto da Bodoquena.. 27

Figura 2 - Mapa do Assentamento Guaicurus, Bonito - MS. ............................ 29

Figura 3 - Vista frontal do domicilio do lote 20 ............................................44

Figura 4 - Vista lateral de parte do domicilio e anexos do lote $20 . \ldots \ldots \ldots \ldots \ldots \ldots \ldots . . . . . . . . . .44$

Figura 5 - Aspecto do galinheiro existente no peridomicílio do lote 20. ............... 45

Figura 6 - Aspecto da gruta (Gruta do Olimpio) próxima ao lote 56. ..................46

Figura 7 - CDC com inseticida colocada próxima ao galinheiro do lote 02 .......... 47

Figura 8 - Armadilha de Shannon colocada próximo ao galinheiro do lote 20 ...... 48

Figura 9 - Armadilha automática luminosa com manguito colocada na mata. ....... 50

Figura 10 - Mapa do Assentamento Guaicurus, Bonito - MS com a distribuição dos lotes, assinalados em amarelo, onde ocorreram capturas de flebotomíneos.......... 51

Figura 11 - Distribuição dos lotes onde foi pesquisada a presença de anticorpos anti-Leishmania em cães, por meio da RIFI, no Assentamento Guaicurus, Bonito MS. Naqueles assinalados em amarelo, os cães foram não reagentes e em rosa, reagentes.

Figura 12 - Cão com emagrecimento e crescimento de unhas. ..........................60

Figura 13 - Cão com emagrecimento acentuado e onicogrifose. ....................... 60

Figura 14 - Cão com alopecia e lesões no tegumento. .....................................61

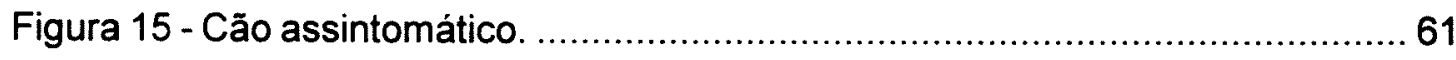

Figura 16 - Várias amastigotas de Leishmania encontradas no esfregaço de aspirado de medula óssea do cão Xebinha (A). Uma forma amastigota e uma tripomastigota no esfregaço de medula óssea (B). Diversas formas tripomastigotas de Trypanosoma evansi observadas em toda a extensão da lâmina desta amostra (C). 65

Figura 17 - Seqüências de nucleotídeos determinadas para o produto da PCR de DNA da amostra do cão Xebinha, alinhadas com as seqüências de cepas de referência do SSU rDNA, conforme descrito por ULIANA et al. (1994), permitindo a identificação dos parasitas deste animal. Produto da PCR com S4 e S12 (1) e "nested"-PCR com S17 e S18 (2) demonstrou infecção por Trypanosoma evansi e Leishmania (L.) chagasi, respectivamente. Os pontos representam bases idênticas a sequência de $L$. (L.) amazonensis e o til representa a posição de inserções na seqüência de $T$. evansi para alinhar as seqüências das espécies de Leishmania com as do Trypanosoma. 
Figura 18 - Eletroforese em gel de agarose do produto da PCR obtido com os oligonucleotideos S4 e S12. M = marcador molecular lambda/Hind III; canaletas de 1 a 5 = DNA de amostras de creme leucocitário ou aspirado de medula óssea dos cães; 6 = DNA de promastigotas de Leishmania (L.) amazonensis (controle positivo); 7 = controle negativo sem DNA. 68

Figura 19 - Eletroforese em gel de agarose do produto da PCR obtido com os oligonucleotideos $\mathbf{S 1 7}$ e $\mathbf{S 1 8}$. $M=$ marcador molecular $1 \mathrm{~kb}$ DNA; canaletas de 1 a 22 = DNA de amostras de creme leucocitário ou aspirado de medula óssea dos cães; 23 = DNA de promastigotas de Leishmania (L.) amazonensis (controle positivo); 24 = controle negativo sem DNA. 69

Figura 20 - Seqüências de nucleotideos determinadas para o produto da "nested"PCR de DNA das amostras alinhadas com as seqüências de cepas de referéncia do SSU rDNA, conforme descrito por ULIANA et al. (1994), permitindo a identificação da espécie de Leishmania. Cão Pitoco está infectado por L. (L.) chagasi, cão Trovão por L. (L.) amazonensis e cão Camoio por L. (Viannia). Os pontos representam bases idênticas a sequência de $L$. (L.) amazonensis. .......... 70

Figura 21 - Total de flebotomineos capturados, mensalmente, em armadilha CDC com veneno e precipitação mensal no Município de Bonito - MS, novembro/02 a outubro/03.

Figura 22 - Média de Williams mensal de Lu. longipalpis, Ny. whitmani e Lu. almerioi, Assentamento Guaicurus e precipitação mensal no Municipio de Bonito, novembro/2002 a outubro/2003. 86

Figura 23 - Média de Williams para machos e fêmeas de Lu. longipalpis para alguns ecótopos, novembro de 2002 a outubro de 2003.

Figura 24 - Média de Williams para machos e fêmeas de Lu. almerioi para alguns ecótopos, novembro de 2002 a outubro de 2003.

Figura 25 - Média de Williams para machos e fêmeas de $\mathrm{Ny}$. whitmani para alguns ecótopos, novembro de 2002 a outubro de 2003. 


\section{RELAÇÃO DAS TABELAS}

Tabela 1 - Resultados obtidos pela reação de imunofluorescência indireta (RIFI) e o ensaio imunoenzimático (EIE) nas amostras de soro dos cães.

Tabela 2 - Resultados obtidos pela reação de imunofluorescência indireta e o ensaio imunoenzimático nas amostras de sangue em papel filtro dos cães.

Tabela 3 - Resultados obtidos pela reação de imunofluorescência indireta entre a primeira e segunda amostras de soro dos 28 cães pesquisados.

Tabela 4 - Resultados obtidos entre a primeira e a segunda amostras de sangue em papel filtro por meio da reação de imunofluorescência indireta.

Tabela 5 - Resultados obtidos pelo ensaio imunoenzimático entre a primeira e segunda amostras de soro dos 28 cães pesquisados.

Tabela 6 - Resultados obtidos entre a primeira e a segunda amostras de sangue em papel filtro por meio do ensaio imunoenzimático.

Tabela 7: Resultados das PCR com os pares de oligonucleotídeos S4/S12 e S17/S18 utilizando amostras de DNA extraidas de creme leucocitário e aspirado de medula óssea de cães do Assentamento Guaicurus, município de Bonito, MS. .... 68

Tabela 8 - Distribuição dos 27 cães com PCR (S17/S18) positiva para Leishmania e destes, os reagentes pela RIFI ou EIE na segunda amostra de soro, segundo os sinais clínicos.

Tabela 9 - Distribuição dos cães reagentes na segunda amostra de soro pela RIFI ou EIE, segundo os sinais clinicos sugestivos de leishmanioses, dentre os 27 cães infectados por Leishmania detectados pela PCR (S17/S18).

Tabela 10 - Distribuição dos cães reagentes na primeira amostra de soro pela RIFI ou EIE, segundo os sinais clinicos sugestivos de leishmanioses, dentre os 27 cães infectados por Leishmania detectados pela PCR (S17/S18).

Tabela 11 - Flebotomíneos capturados em armadilhas de Shannon e CDC com e sem inseticida no Assentamento Guaicurus, outubro de 2002 a outubro de 2003, segundo sexo, espécie e lote de captura.

Tabela 12 - Flebotomíneos capturados em armadilhas de Shannon e CDC com e sem inseticida, segundo sexo, espécie e ambiente de captura, Assentamento Guaicurus, outubio/2002 a outubro/2003.

Tabela 13 - Flebotomíneos capturados em armadilha automática luminosa com inseticida, segundo os sítios de captura e as espécies, Índice de Diversidade e Média de captura, novembro/02 a outubro/03.

Tabela 14 - Média de Williams para as três espécies de flebotomineos mais freqüentes do Assentamento Guaicurus, segundo os ambientes de captura com armadilhas automáticas luminosas com inseticida, novembro de 2002 a outubro de 2003. 
Tabela 15 - Média de Williams mensal de Lu. longipalpis, Ny. whitmani e Lu. almerioi no Assentamento Guaicurus, no período de novembro de 2002 a outubro de 2003.

Tabela 16 - Média de Williams para machos e fêmeas de Lu. longipalpis para alguns ecótopos, novembro de 2002 a outubro de 2003.

Tabela 17 - Média de Williams para machos e fêmeas de Lu. almerioi para alguns ecótopos, novembro de 2002 a outubro de 2003.

Tabela 18 - Média de Williams para machos e fêmeas de Ny. whitmani para alguns ecótopos, novembro de 2002 a outubro de 2003.

Tabela 19 - Indice de Abundância da Espécie Padronizado (IAEP) dos flebotomíneos capturados em CDC com veneno, Assentamento Guaicurus, novembro/02 a outubro/03

Tabela 20 - Número de fêmeas de flebotomineos dissecadas e infectadas por flagelados, conforme observação microscópica, segundo espécie e o lote de captura, Assentamento Guaicurus, outubro/02 a outubro/03.

Tabela 21 - Número de fêmeas dissecadas e encontradas infectadas pela PCR com oligonucleotideos $\$ 17$ e $\mathrm{S18}$, segundo local de captura no Assentamento Guaicurus, 2002-2003.

Tabela 22 - Taxas de infecção natural por Leishmania em fêmeas de flebotomíneos pesquisadas por meio da PCR com oligonucleotideos S17 e S18, segundo local de captura no Assentamento Guaicurus, 2002-2003.

Tabela 23 - Taxas de infecção natural em fêmeas de flebotomíneos pesquisadas por meio da PCR com oligonucleotídeos S17/S18, conforme a espécie de Leishmania e local de captura no Assentamento Guaicurus, 2002-2003. 100 


\section{ABREVIATURAS}

DNA: Ácido desoxirribonucléico

EDTA: Ácido etilenodiaminotetracético

EIE: Ensaio Imunoenzimático

FSP/USP: Faculdade de Saúde Pública da Universidade de São Paulo

G6PD: Glicose - 6 - fosfato dehidrogenase

IAEP: Índice de Abundância de Espécies Padronizado

ICB/USP: Instituto de Ciências Biomédicas da Universidade de São Paulo

INCRA: Instituto Nacional de Colonização e Reforma Agrária

LabZoo-VIS: Laboratório de Zoonoses e Doenças Transmitidas por Vetores da

Vigilância em Saúde da Prefeitura do Município de São Paulo

LTA: Leishmaniose Tegumentar Americana

LVA: Leishmaniose Visceral Americana

MS: Estado de Mato Grosso do Sul

OMS: Organização Mundial da Saúde

PCR: Reação em Cadeia da Polimerase

rDNA: DNA ribossômico

RIFI: Reação de Imunofluorescência Indireta

SSU: Subunidade menor do ribossomo (18S)

TE: Tris - EDTA

Tris: Tris(hidroximetil)aminometano

UNIDERP: Universidade para o Desenvolvimento do Estado e da Região do Pantanal 


\section{INTRODUÇÃO}

\subsection{Aspectos gerais}

As leishmanioses são zoonoses conseqüentes do parasitismo por protozoários da ordem Kinetoplastida, família Trypanosomatidae, gênero Leishmania, em hospedeiros vertebrados (DEDET 1993).

São reconhecidas cerca de 25 espécies de Leishmania que podem causar a doença no homem (LAINSON e SHAW 1987; JACOBSON 2003). Embora, morfologicamente muito parecidas, produzem distintas patologias (ASHFORD 2000), cuja feição comum a todas, é a cronicidade da doença. A infecção pode ser predominantemente visceral, restrita à pele ou disseminar-se para as mucosas, causando a leishmaniose cutâneo-mucosa (ROSE et al. 2004).

Amplamente distribuída no mundo, inside de forma endêmica em 88 paises, distribuídos nos cinco continentes, África, Ásia, Europa, América do Norte e América do Sul (JACOBSON 2003). Na Oceania, considerada livre da endemia (HERWALDT 1999; HANDMAN 2001), constatou-se, recentemente, a ocorrência da leishmaniose cutânea em cangurus vermelhos da Austrália (ROSE et al. 2004).

Segundo estimativas da Organização Mundial da Saúde - OMS (1990), cerca de 350 milhōes de pessoas no mundo estão sob o risco de adquirir a doença, existem, aproximadamente, 12 milhões de infectados e cerca de 1,5 milhão de novos casos são registrados a cada ano. O Brasil 
encontra-se entre os cinco países do mundo que respondem por cerca de $90 \%$ dos casos de leishmaniose nas formas visceral e tegumentar.

As espécies do gênero Leishmania circulam em ampla variedade de mamiferos silvestres e menos freqüentemente, em animais domésticos.

Na América, os reservatórios são mamiferos silvestres ou domésticos pertencentes às ordens Marsupialia, Xenarthra, Primatas não humanos, Carnivora, Perissodactyla e Rodentia (DEDET 1993), nos quais se alimentam os vetores.

Os vetores são dípteros da familia Psychodidae, subfamília Phlebotominae, sendo conhecidas, nas Américas, cerca de 470 espécies, das quais, aproximadamente, 60 estão envolvidas na transmissão das leishmanioses (KILLICK-KENDRICK 1990; DEDET 1993; SANTOS et al. 1998; GALATI et al. 2003b). Dessas espécies, algumas são vetores comprovados, ou seja, apresentam distribuição geográfica coincidente com a da doença, alta densidade, demonstração de que se infectam e transmitem experimentalmente o parasita que causa a doença no homem, são antropofilicas e apresentam estreito grau de relacionamento com os reservatórios na natureza (KILLICK-KENDRICK 1990), outras por evidências epidemiológicas, acrescidas ou não da identificação da infecção natural pelos parasitas (DEDET 1993).

Os flebotomíneos têm seus criadouros em solo úmido e rico em matéria orgânica, entre ou embaixo de rochas, entre raízes e folhas caídas e em tocas de animais, geralmente ao abrigo da incidência direta da luz solar. Estes microhabitats, bem como tronco de árvores e arbustos, são utilizados 
como locais de repouso para os adultos. Somente as fêmeas são hematófagas (FORATTINI 1973).

A maior diversidade das espécies de flebotomíneos encontra-se nas florestas tropicais, mas também estão presentes em ambientes modificados pelo homem, tais como áreas de cultivo e urbanizadas. Os adultos afastamse pouco dos locais de abrigo, geralmente, até 200 metros (YOUNG e DUNCAN 1994).

$\mathrm{Na}$ América, o protozoário associado à leishmaniose visceral é Leishmania (Leishmania) chagasi, e nas formas dermatrópicas, diversas espécies pertencentes aos subgêneros Leishmania e Viannia (THOMAZSOCCOL et al. 1993).

No continente americano, as leishmanioses estão presentes em 21 paises (DEDET 1993).

Casos autóctones de leishmaniose visceral americana (LVA) têm sido assinalados no Brasil, Argentina, Paraguai, Peru, Bolivia, Colombia, Venezuela, Equador, El Salvador, Guatemala, Honduras, México, Nicarágua, Suriname, Estados Unidos e nas ilhas de Guadalupe e Martinica (DEDET 1993; GRIMALDI e TESH 1993).

A leishmaniose tegumentar americana (LTA) ocorre na maioria dos países da América, com exceção do Canadá, algumas ilhas do Caribe, Chile e Uruguai (GRIMALDI e TESH 1993; YOUNG e DUNCAN 1994). 


\subsection{Leishmanioses no Brasil}

No Brasil, as leishmanioses têm grande relevância na Saúde Pública, em virtude da larga distribuição geográfica e severidade das manifestações clínicas. Nos últimos anos, essa importância vem crescendo devido ao aumento das incidências, ocorrência de algumas formas da doença em novas áreas geográficas e tendências à urbanização. Enfatiza-se também as dificuldades no diagnóstico, tratamento e controle, a complexidade dos quadros epidemiológicos e a variedade de ambientes em que ocorrem (GOMES 1992, 1994; MARZOCHI 1992; MARZOCHI e MARZOCHI 1994; GOMES et al. 1996; MINISTÉRIO DA SAÚDE 2002a).

A leishmaniose visceral americana tem ocorrido em todos os estados da Região Nordeste, Centro-Oeste e Sudeste do país, além dos Estados do Pará, Tocantins e Roraima, sendo que o território brasileiro contribui com mais de $90 \%$ dos casos humanos que ocorrem nas Américas (GRIMALDI et al. 1987; DEDET 1993; MINISTÉRIO DA SAÚDE 2002a).

Na epidemiologia desta zoonose, o cão (Canis familiaris) exerce importante papel como reservatório doméstico de Leishmania (L.) chagasi (DEANE 1956; ARIAS et al. 1996; GOMES et al. 1996), enquanto canideos silvestres, como as raposas Lycalopex vetulus e Cerdocyon thous, representam reservatórios primários do parasita (DEANE 1956; DEDET 1993). Didelfídeos, na Colômbia, têm sido apontados como importantes reservatórios (TRAVI et al. 1994), no Brasil, a infecção foi identificada em Didelphis albiventris (SHERLOCK et al. 1984) e na Venezuela em Didelphis 
marsupialis (ZULUETA et al. 1999). A possibilidade de outros animais, como os eqüinos, atuarem como reservatórios domésticos do parasita tem sido investigada (CERQUEIRA et al. 1999).

O vetor incriminado na maioria das áreas de transmissão de LVA tem sido Lutzomyia (Lutzomyia) longipalpis (DEDET 1993; SHERLOCK 1994; FERRO et al. 1995). Todavia, nos municipios brasileiros de Ladário e Corumbá no Mato Grosso do Sul, Lutzomyia (L.) cruzi parece exercer este papel (GALATI et al. 1997; SANTOS et al. 1998), assim como Pintomyia (Pifanomyia) evansi, em um foco, na Colômbia (TRAVI et al. 1996).

No passado, a LVA ocorria basicamente em área rural com transmissão doméstica ou peridoméstica. Após a década de 70 , tem-se observado uma crescente urbanização ou uma crescente "ruralização" da periferia de áreas urbanas. Assim, a transmissão tem ocorrido em cidades do interior e em capitais de estados da Região Nordeste, Sudeste e CentroOeste do pais como Natal, São Luís, Belo Horizonte, Rio de Janeiro e Campo Grande (NUNES et al. 1988; MARZOCHI et al. 1994; SHERLOCK 1994; CUNHA et al. 1995; GOMES et al. 1996; SILVA et al. 1997; SANTOS et al. 1998; GALIMBERTTI et al. 1999; TOLEZANO et al. 1999; PALATNIKDE-SOUSA et al. 2001; MINISTÉRIO DA SAÚDE 2002a).

A Leishmaniose Tegumentar Americana (LTA) atinge todos os estados do território nacional (COUTINHO et al. 1981; MARZOCHI 1992; MINISTÉRIO DA SAÚDE 2002b) e com maior freqüência, causam a infecção no homem, as espécies Leishmania (Viannia) braziliensis, 
Leishmania (Viannia) guyanensis e Leishmania (Leishmania) amazonensis (GOMES 1992; LAINSON et al. 1994).

Os principais vetores pertencem aos subgêneros Nyssomyia e Psychodopygus do gênero Lutzomyia (DEDET 1993), que segundo GALATI (1995) são representantes dos gêneros Bichromomyia, Nyssomyia e Psychodopygus.

As espécies do protozoário apresentam diferente distribuição geográfica no território brasileiro. Leishmania (L.) amazonensis encontra-se nos Estados do Amazonas, Bahia, Ceará, Goiás, Maranhão, Mato Grosso, Minas Gerais, São Paulo, Pará, Paraná e Santa Catarina, Leishmania (V.) guyanensis nos Estados do Amapá, Amazonas, Mato Grosso, Pará e Roraima, enquanto que Leishmania (V.) braziliensis apresenta distribuição mais ampla, abrangendo os Estados do Amapá, Amazonas, Pará, Rondônia, Maranhão, Bahia, Ceará, Paraíba, Goiás, Mato Grosso, Mato Grosso do Sul, Espírito Santo, Minas Gerais, Rio de Janeiro, São Paulo, Paraná, Rio Grande do Sul e Santa Catarina (GRIMALDI et al. 1987; SILVEIRA et al. 1990; MARZOCHI 1992; DEDET 1993; LAINSON et al. 1994; TOLEZANO 1994, 2000; NUNES et al. 1995; DIAS et al. 1997; GRISARD et al. 2000).

Casos humanos de LTA associados a outras espécies de Leishmania, têm sido relatados, como Leishmania (V.) naiffi nos Estados do Pará e Amazonas, Leishmania (V.) lainsoni, Leishmania (V.) shawi e, a recentemente descrita, Leishmania (Viannia) lindenberg, no Estado do Pará (SILVEIRA et al. 1987, 2002; LAINSON et al. 1990; SHAW et al. 1991). 
Leishmania (V.) guyanensis, associada à floresta primitiva, é transmitida, principalmente, pelo vetor Nyssomyia umbratilis e tem os edentados Choloepus didactylus e Tamandua tetradactyla como reservatórios comprovados (GOMES 1992; GRIMALDI e TESH 1993; LAINSON et al. 1994).

Leishmania (L.) amazonensis é o agente associado aos casos de leishmaniose cutâneo-difusa, forma da doença de mais difícil cura ou incurável. O principal vetor é Bichromomyia flaviscutellata e tem como principais reservatórios os roedores Proechimys guyanensis e Oryzomys sp, ocorrendo em ambientes de floresta úmida, várzeas e margens de rios (GOMES 1992; GRIMALDI e TESH 1993; LAINSON et al. 1994).

O ciclo epidemiológico de Leishmania (V.) braziliensis - espécie responsável pelos casos mucocutâneos - fora da região norte do país, permanece ainda não esclarecido, existindo várias espécies de flebotomíneos incriminados e os reservatórios silvestres não foram determinados de forma definitiva. Porém, esse parasita já foi observado em diversos animais domésticos, como cães (HERRER e CHRISTENSEN 1976; DIAS et al. 1977; ARAUJO FILHO et al. 1981b; MARZOCHI et al. 1982; AGUILAR et al. 1984, 1989; BARRETTO et al. 1984; COUTINHO et al. 1985; FALQUETO et al. 1986; PIRMEZ et al. 1988; ROSA et al. 1988; GOMES et al. 1990; YOSHIDA et al. 1990; LONARDONI et al. 1993; VASCONCELOS et al. 1994; MADEIRA et al. 2003), eqüinos (AGUILAR et al. 1989; YOSHIDA et al. 1990; BARBOSA-SANTOS et al. 1994), asnos (AGUILAR et al. 1984; ROSA et al. 1988) e roedores sinantrópicos 
(ARAUJO FILHO et al. 1981a; MAGALHÃES ROCHA et al. 1988; PETERSON et al. 1988). Inclusive o homem tem sido considerado como fonte de infecção para o vetor (MARZOCHI 1992). Recentemente, foram encontrados infectados pela Leishmania (V.) braziliensis, no Estado de São Paulo, duas espécies de roedores silvestres, Oxymicterus quaestor e Bollomys lasiurus (TOLEZANO 2000) e, em Pernambuco, esta última espécie, assim como o roedor sinantrópico, Rattus rattus (BRANDÃO-FILHO et al. 2003).

A infecção humana, no passado, estava relacionada com a penetração do homem em ambientes florestais primitivos - onde ocorre o ciclo silvestre do parasita - para derrubada de matas, abertura de estradas e implantação de povoados em áreas pioneiras, sendo que os indivíduos acometidos eram, basicamente, adultos do sexo masculino (GOMES et al. 1990; MINISTÉRIO DA SAÚDE 1994).

Atualmente, além desse padrão de transmissão da LTA, observa-se que nas áreas de colonização antiga, com grande devastação das matas, os focos de leishmaniose estão restritos a alguns resíduos da cobertura vegetal primitiva (GOMES 1992; TOLEZANO 1994).

Esses resíduos, em franco processo de degradação, obrigam as populações de reservatórios silvestres a procurarem o ambiente extraflorestal (peridomiciliar e domiciliar) em busca de alimentos. Processo semelhante ocorre com os vetores, que buscam no homem e animais domésticos a fonte alimentar para sobrevivência (GOMES 1992). 
Assim, parece que as espécies de Leishmania estão se adaptando a ambientes alterados, principalmente, a $L$. (V.) braziliensis, que vem apresentando características sinantrópicas, levando à infecção do homem em seu domicilio, atingindo indistintamente, ambos os sexos e faixas etárias, a exemplo do que ocorre nas áreas florestais remanescentes da mata Atlântica da Região Sudeste, nos Estados do Espírito Santo, Rio de Janeiro e São Paulo, onde Nyssomyia intermedia s. lat. representa o principal vetor (RANGEL et al. 1984; GOMES 1992, 1994; MARZOCHI e MARZOCHI 1994).

\subsection{As leishmanioses em Mato Grosso do Sul}

Casos humanos autóctones de leishmaniose tegumentar americana têm sido notificados desde 1983 em Mato Grosso do Sul (MS) (MINISTÉRIO DA SAÚDE 2002b).

A penetração do homem em ambiente silvestre, para implantação de projetos agropecuários, aberturas de estradas e assentamentos de trabalhadores rurais sem terra, pelo Instituto Nacional de Colonização e Reforma Agrária (INCRA), como já observado em outras regiões do Brasil (PESSÓA e BARRETO 1948; BARBOSA et al. 1965; PESSOA e MARTINS 1982; NASCIMENTO 1986) tem propiciado o surgimento de casos da doença.

A LTA tem sido registrada em 72 dos 77 municípios, acometendo mais os indivíduos do sexo masculino e faixa etária acima de 15 anos, 
ocorrendo transmissão em ambiente rural (NUNES 2001; GALATI et al. 2003b).

Estudos epidemiológicos sobre esta zoonose em MS são escassos, até o momento, apesar da ampla dispersão e do crescente número de casos da doença.

NUNES et al. (1995) em pesquisa realizada no periodo de 1991 a 1994, encontraram 32 pessoas reagentes à intradermoreação de Montenegro e 8 casos de doença em atividade dentre 150 moradores de Boa Sorte, Município de Corguinho. Sete pacientes apresentaram a forma cutânea e um a forma mucosa, com destruição de septo nasal. As lesões ativas e ou cicatriciais localizavam-se, mais em áreas descobertas do corpo.

Os casos ocorreram em adultos acima de 20 anos, de ambos os sexos, predominantemente nos homens. Os pacientes executavam atividades de desmatamentos nas matas ciliares e cerrados, onde também, caçavam durante as primeiras horas da noite. As mulheres acometidas realizavam atividades domésticas ao entardecer, como lavar roupa em córrego circundado por mata nativa ou cortar lenha em área de cerrado.

Esses fatos, associados ao insignificante número de flebotomineos capturados no interior do domicílio (GALATI et al. 1996) e ao não encontro de animais domésticos infectados (NUNES et al. 1994), sugeriram que a transmissão da parasitose ocorreu em ambiente extradomiciliar.

Nyssomyia whitmani (ANTUNES e COUTINHO 1939) foi a espécie de flebotomíneo dominante entre as 26 espécies assinaladas nos diferentes ambientes estudados da fazenda Boa Sorte. Esta espécie foi indicada como 
vetora de leishmaniose tegumentar naquela região, devido ao seu grau de antropofilia, atividade predominante entre 17 e 21 horas, e o encontro de um espécime com flagelados no intestino posterior e médio, em uma área em que o parasita foi identificado como L. (V.) braziliensis (GALATI et al. 1996).

Em trabalho desenvolvido junto ao Assentamento Guaicurus, municipio de Bonito, NUNES (2001), constatou que, entre janeiro de 1998 a dezembro de 1999, foram notificados sete casos de LTA em moradores do Assentamento e um caso em indio Kadwéo residente em uma área adjacente conhecida como Campo dos Índios, no município de Porto Murtinho.

Todos os pacientes tiveram a forma cutânea da parasitose, com úlceras únicas ou múltiplas. $O$ parasita foi identificado como L. (V.) braziliensis.

A observação de que todos os casos ocorreram em adultos do sexo masculino, que trabalhavam em matas ou caçavam à noite em área de cerradão, onde $N y$. whitmani foi a espécie de flebotomíneo predominante (Galati, 2000), aliada ao não encontro de LTA em mulheres, crianças e animais domésticos, sugeriu que a transmissão não ocorreu no domicilio ou peridomicilio (NUNES 2001).

Portanto, a transmissão de LTA, tanto em Boa Sorte, município de Corguinho, centro de MS, como no Assentamento Guaicurus, município de Bonito, sudoeste do Estado pôde ser enquadrada no padrão epidemiológico de doença ocupacional, em que aos determinantes biológicos se somaram e 
interagiram os ecológicos, os econômicos, os sociais e os culturais (NUNES et al. 1994; NUNES, 2001).

Em relação à leishmaniose visceral, sua presença no Estado é relatada desde o início do século $X X$, visto que, o primeiro caso humano autóctone do continente americano, diagnosticado em 1913, em Assunção, no Paraguai, era procedente de Porto Esperança, municipio de Corumbá, MS (MIGONE 1913; DEANE 1956).

Foram registrados, ainda, casos esporádicos da doença em zona rural de outros municipios, no transcorrer do século (CHAGAS e CHAGAS 1938; OLIVEIRA, 1938; ARRUDA et al. 1949).

A partir de 1980, notificações de casos humanos, diagnosticados clinicamente, no Municipio de Corumbá e a observação de cães com aspectos sugestivos de leishmaniose visceral nas ruas da cidade, levaram a estudos para esclarecer componentes epidemiológicos da parasitose nesta área.

Em inquérito sorológico realizado na população canina de Corumbá, em 1983, encontrou-se $8,7 \%$ de reagentes dentre 481 animais examinados. Os parasitas isolados de cães foram identificados bioquimicamente como $L$. (L.) chagasi (NUNES et al. 1988; YAMAMOTO et al. 1988).

Outros inquéritos sorológicos demonstraram, ainda, alta taxa de infecção na população canina (24\%) dos municípios de Corumbá e de Ladário (SANTOS et al. 1998), considerados hiperendêmicos para a parasitose (GOMES et al. 1996). 
Nos últimos anos, observou-se a expansão da leishmaniose visceral para outros municípios do Estado: Água Clara, Anastácio, Antônio João, Aquidauana, Bela Vista, Bodoquena, Bonito, Brasilandia, Costa Rica, Coxim, Dois Irmãos do Buriti, Guia Lopes da Laguna, Jardim, Juty, Miranda, Nioaque, Paranaíba, Ribas do Rio Pardo, Rio Verde, Sidrolândia, Terenos, Três Lagoas e Campo Grande (NUNES 2001; SECRETARIA DE ESTADO DA SAÚDE DE MATO GROSSO DO SUL 2002a).

A fauna flebotomínea pesquisada em área urbana e na periferia de Corumbá, no periodo de 1984 a 1986, foi composta por Brumptomyia brumpti (Larrouse, 1920), Evandromyia (Barrettomyia) corumbaensis (Galati, Nunes, Oshiro \& Rego Jr., 1989), Lutzomyia (Lutzomyia) cruzi (Mangabeira, 1938), Lutzomyia (Lutzomyia) forattinii Galati, Rego Jr., Nunes \& Teruya, 1985, Martinsmyia oliveirai (Martins, Silva \& Falcão, 1970), Micropygomyia (Sauromyia) peresi (Mangabeira, 1942), Evandromyia (Barrettomyia) sallesi (Galvão \& Coutinho, 1940) e Sciopemyia sordellii (Shannon \& Del Pont, 1927) (GALATI et al. 1985; GALATI et al. 1989; GALATI et al. 1997).

A ausência de Lutzomyia (Lutzomyia) longipalpis (Lutz \& Neiva, 1912) nas capturas e a predominância de $L u$. cruzi, no peri e no intradomicilio, indicaram a possibilidade desta espécie atuar como vetora de LVA em Corumbá (GALATI et al. 1997). Posteriormente, foram encontrados espécimes com promastigotas restritas à porção anterior do tubo digestivo, sendo o parasita identificado como $L$. ( $L$.) chagasi, por meio de anticorpos monoclonais (SANTOS et al. 1998). Esses encontros, associados aos dados epidemiológicos (GALATI et al. 1997), apontaram Lu. cruzi como principal 
vetor de LVA nos municipios de Corumbá e de Ladário (SANTOS et al. 1998).

Existe a possibilidade de que Lu. forattinii, também, participe do ciclo de transmissão da doença, na área rural e na periferia do municipio de Corumbá, visto a sua expressiva densidade em ecótopo natural, localizado nas imediações da cidade e a sua ocorrência em explosões simultâneas com as de Lu. cruzi, com invasão de domicílio. Soma-se a isto, o fato de ser antropofilica e pertencer ao mesmo grupo monofilético de Lu. longipalpis e de Lu. cruzi (GALATI et al. 1997; NUNES 2001).

Recentemente, foi assinalada a presença de Lu. longipalpis em um foco de leishmaniose visceral em Corumbá, apresentando assim, uma nova variável na epidemiologia da doença naquele municipio (SANTOS et al. 2003).

Em municípios do Estado, como Miranda tem sido encontrada somente Lu. longipalpis, enquanto que em outros como Anastácio, Aquidauana e Campo Grande são relatadas a presença tanto de $L U$. longipalpis como de Lu. cruzi (OLIVEIRA 2000; SECRETARIA DE ESTADO DA SAÚDE DO MATO GROSSO DO SUL 2002b). Deste modo, torna-se importante a realização de mais pesquisas visando determinar o significado epidemiológico desses encontros.

Em 1999, foi realizado inquérito sorológico na população canina do Assentamento Guaicurus, Município de Bonito, observando-se $23,7 \%$ de reagentes dentre os 97 cães examinados. Os parasitas isolados foram 
identificados por anticorpos monoclonais como L. (L.) chagasi. Não foram notificados casos humanos de LVA no Assentamento (NUNES 2001).

Neste estudo foram encontradas 13 espécies de flebotomíneos, entre elas Lu. longipalpis, que foi a espécie mais freqüente e presente em quase todos os ambientes estudados sendo mais expressiva em pocilga, em abrigo de ovinos, galinheiro e no domicilio (NUNES 2001; GALATI et al. 2003b), podendo ser suspeita pela transmissão de leishmaniose visceral entre os cães do Assentamento Guaicurus.

Foram dissecadas 230 fêmeas de flebotomíneos, capturadas com armadilha luminosa, Shannon e aspiração em iscas animais, para identificação de infecção natural pelos métodos clássicos e não foram encontrados espécimes com flagelados (NUNES 2001; GALATI et al. 2003b).

Dentre a fauna flebotominea do Guaicurus, a alta densidade populacional de Lutzomyia (Lutzomyia) almerioi Galati \& Nunes, 1999, espécie descrita a partir de estudos na Serra da Bodoquena, mereceu destaque por fazer parte do mesmo grupo monofilético de Lu. longipalpis, Lu. cruzi e Lu. forattinii (GALATI et al. 1997). Soma-se o fato de que Lu. almerioi apresentou freqüência alta em cavernas da Província Espeleológica da Bodoquena (GALATI et al. 2003a), onde existem mamiferos, que podem atuar como reservatórios silvestres de leishmanioses na região (COSTA e SECOND 1992). 


\subsection{Diagnóstico das leishmanioses}

No diagnóstico das leishmanioses devem ser considerados os aspectos clínicos, epidemiológicos e laboratoriais.

Em relação ao diagnóstico laboratorial, atualmente no Brasil, as técnicas parasitológicas e imunológicas são as mais utilizadas nos programas de controle das leishmanioses (MINISTÉRIO DA SAÚDE 1994; ORGANIZAÇÃO PAN-AMERICANA DA SAÚDE 1997).

Os métodos parasitológicos usados para confirmação de caso fundamentam-se na pesquisa do parasita, em material biológico adequado à suspeita clínica (biópsia de borda de lesão cutânea e/ou aspirado de medula óssea, baço ou linfonodo), por meio de esfregaço em lâmina corado pelo método de Giemsa, inoculação em hamster e cultura in vitro (MINISTÉRIO DA SAÚDE 1994; ORGANIZAÇÃO PAN-AMERICANA DA SAÚDE 1997; HERWALDT 1999). Quando formas promastigotas do parasita são isoladas no meio de cultura, pode-se identificar a espécie de Leishmania por meio da reação de imunofluorescência com anticorpos monoclonais (SHAW et al. 1989).

As técnicas parasitológicas podem apresentar sensibilidade menor que $80 \%$, que ainda pode diminuir devido a dificuldades com contaminação da cultura e a manutenção de hamsters por periodos de 6 meses ou mais. A deteç̧ão do protozoário ao exame microscópico depende da presença de muitos parasitas no material pesquisado e necessita de pessoal técnico treinado e com experiência neste diagnóstico (LOPEZ et al. 1993; ASHFORD et al. 1995). 
As técnicas imunológicas envolvem provas sorológicas para pesquisa de anticorpos anti-Leishmania e testes cutâneos, a fim de detectar resposta imune celular (MINISTÉRIO DA SAÚDE 1994; HERWALDT 1999). Testes sorológicos e intradérmicos não são muito conclusivos, pois podem ocorrer reações cruzadas ou falsos-negativos (MANSON-BAHR 1987).

Os métodos sorológicos são mais úteis para detectar anticorpos na leishmaniose visceral, pois os niveis de anticorpos circulantes nesta zoonose são, significativamente superiores, aos niveis encontrados na leishmaniose tegumentar (DUXBURY e SADUN 1964; BRAY e LAINSON 1965; WALTON et al. 1972; MENDONÇA et al. 1988).

A reação de imunofluorescência indireta (RIFI) è um método sorológico, muito utilizado em estudos sobre leishmanioses envolvendo população humana ou canina (MARZOCHI et al. 1980; IVERSSON et al. 1983; LEOPOLDO e SILVA et al. 1984; COUTINHO et al. 1985; NUNES et al. 1988; PIRMEZ et al. 1988; GOMES et al. 1990; SAN MARTIN-SAVANI 1998) e pode auxiliar no diagnóstico laboratorial das leishmanioses, sobretudo em casos nos quais não é possível encontrar o protozoário (BITTENCOURT et al. 1968; CHIARI et al. 1973; MENDONÇA et al. 1988).

A reação de imunofluorescência indireta é grupo-especifica, portanto, reaçōes cruzadas entre leishmaniose visceral, leishmaniose tegumentar e doença de Chagas podem ocorrer (BRAY e LAINSON 1965; ARAUJO e MAYRINK 1968; FURTADO 1980) e em menor número, com portadores de malária, esquistossomose e lepra (DUXBURY e SADUN 1964). No entanto, 
os títulos de anticorpos são maiores com antígenos homólogos do que com os heterólogos (BRAY e LAINSON 1965; CAMARGO e REBONATO 1969).

As reações cruzadas podem ser diminuídas, aumentando-se as diluições dos soros testados (ARAUJO e MAYRINK 1968; FURTADO 1980). Deste modo, somente títulos iguais ou superiores a 40 podem ser considerados indicativos da infecção (COUTINHO et al. 1985), visto que aquelas podem ocorrer com maior freqüência em títulos menores que esse (LEOPOLDO e SILVA et al. 1984).

A RIFI tem sido a técnica mais empregada em áreas endêmicas de LVA, em inquéritos sobre populações caninas, principalmente para identificar cães infectados que não apresentam sintomas, visando o controle desta zoonose (BADARÓ et al. 1983; MANCIANTI et al. 1986; BADARÓ 1987; BRAGA et al. 1998).

Para a realização da RIFI em inquéritos caninos, utilizam-se, em geral, amostras de sangue colhidas em papel de filtro pela facilidade da coleta e armazenagem no campo e envio ao laboratório (SOUZA e CAMARGO 1966; GUIMARÃES et al. 1986; EVANS et al. 1990; ZICKER et al 1990; MACHADO-COELHO et al. 1995; BRAGA et al. 1998).

O ensaio imunoenzimático (EIE), em geral, apresenta maior sensibilidade do que a RIFI, possibilita o processamento de um grande número de amostras em curto intervalo de tempo e pode propiciar a possibilidade de uso em condições de campo (EVANS et al. 1990; ASHFORD et al. 1993; PARANHOS-SILVA et al. 1996; BARBOSA-DEDEUS et al. 2002). 
O emprego do EIE em amostras de soro de cães tem demonstrado alta sensibilidade em detectar os animais infectados, sendo que sua sensibilidade e especificidade são influenciadas pelo antígeno utilizado na reação (QUINNELL et al. 2001; SINGH e SIVAKUMAR 2003).

O uso de técnicas moleculares para o diagnóstico permite alta sensibilidade e especificidade, além da detecção - possivel a partir de um único parasita na amostra - e caracterização mais rápida do parasita (LOPEZ et al. 1993; ASHFORD et al. 1995; SINGH e SIVAKUMAR 2003).

A sensibilidade e especificidade da reação em cadeia da polimerase (PCR) dependem de vários fatores como protocolo de extração do DNA, os pares de oligonucleotídeos, a amostra que será utilizada, pois pode conter inibidores da enzima Taq-polimerase (REITHINGER et al. 2002).

A PCR tem demonstrado ser uma técnica sensível para detectar infecção canina na leishmaniose tegumentar (REITHINGER et al. 2000) e na leishmaniose visceral (QUINNELL et al. 2001; SILVA et al. 2001).

Entre as várias seqüências alvo empregadas na PCR para Leishmania, utiliza-se uma região do DNA ribossômico (rDNA) que codifica a subunidade menor do ribossomo (SSU). Esta região está presente em grande número de cópias nos organismos e inclui regiōes conservadas e variáveis, que permitem identificar tanto o gênero Leishmania quanto os subgêneros deste parasita (ULIANA et al. 1994).

Regiōes conservadas do gene G6PD, presente em cópia única no genoma de Leishmania e que codifica a enzima glicose-6-fosfato desidrogenase, têm sido utilizadas como seqüências alvo em PCR's para 
detectar DNA de Leishmania do subgênero Viannia e discriminar, pelo emprego de diferentes oligonucleotideos, Leishmania (Viannia) braziliensis das demais espécies pertencentes ao mesmo subgênero (CASTILHO et al. 2003).

\subsection{Infecção natural por Leishmania nos flebotomineos}

Nos flebotomineos o encontro de infecção natural por protozoários do gênero Leishmania é imperativo para identificar possiveis espécies vetoras em determinada área endêmica, bem como suas taxas de infeç̧ão.

Os métodos mais usuais para se estimar a infecção natural dos vetores têm sido a dissecção das fêmeas para observação de seu conteúdo intestinal e tentativa de isolamento em meio de cultura.

A observação ao microscópio não é exata, visto que podem ocorrer outros protozoários flagelados nestes insetos, indistinguiveis morfologicamente. A cultura freqüentemente contamina, não permitindo o isolamento do parasita e sua posterior identificação (MICHALSKY et al. 2002).

As técnicas moleculares com maior sensibilidade e especificidade têm se demonstrado úteis para estudos epidemiológicos, que visam determinar a infecção natural por Leishmania em populações de flebotomineos e identificar possiveis vetores em áreas endêmicas (PEREZ et al. 1994; RODRIGUEZ et al. 1999; SILVA e GRUNEWALD 1999; ARANSAY et al. 2000; MICHALSKY et al. 2002). 


\subsection{Justificativa}

Em decorrência dos aspectos abaixo arrolados:

- a gravidade das manifestações clínicas da LVA (BADARÓ et al. 1986; MONTEIRO et al. 1994);

- a LVA ter adquirido, na atualidade, nova dimensão como grave infecção oportunista, quando associada à síndrome da imunodeficiência adquirida (FERREIRA 1996; SANTA ROSA e OLIVEIRA 1997; BORGES et al. 1999; FERREIRA et al. 2001, SILVA et al. 2002);

- a presença de LVA no Mato Grosso do Sul, desde a década de 80 do século passado (NUNES et al. 1988) em Corumbá e Ladário, e sua expansão nos últimos anos para muitos outros municípios, inclusive para Campo Grande, a capital do Estado (SECRETARIA DE ESTADO DA SAÚDE DE MATO GROSSO DO SUL 2002a);

- a necessidade de diagnóstico precoce e tratamento especifico para a prevenção da morte por LVA, particularmente entre os mais pobres, contingente que inclui a maioria das vítimas da parasitose (GOMES et al 2001);

- a demonstração de que além dos cães outros reservatórios, tais como: pessoas, raposas e marsupiais, podem infectar o vetor de LVA (DEANE 1956; SHERLOCK et al. 1984; TRAVI et al. 1994; ARIAS et al. 1996; ZULUETA et al. 1999; COSTA et al. 2000); 
- a necessidade de inquéritos sorológicos amostrais de infecção canina e a intensificação da identificação de vetores em áreas de ocorrência de LVA (GOMES et al. 2001);

- a prioridade para o controle de vetores, na estratégia atual do Ministério da Saúde para o combate da LVA no Brasil (GOMES et al. 2001);

- a necessidade de pesquisas sobre a epidemiologia da LVA, que não está, ainda, devidamente esclarecida, para que as recomendaçōes para o controle sejam adequadas às peculiaridades regionais (GOMES et al. 2001);

- a ampla distribuição da LTA no Mato Grosso do Sul, 72 dos 77 municípios (NUNES 2001; GALATI et al. 2003b) e a ocorrência de formas clínicas graves em pacientes oriundos de diversas regiōes (MENEZES et al. 1986; NUNES et al. 1995);

- a necessidade em áreas de ocorrência de LTA, de estudos sobre sua estrutura epidemiológica, seus aspectos clínicos, etiológicos e ecológicos, para determinação dos fatores envolvidos no comportamento da prevalência da infecção humana (LAINSON e SHAW 1970, 1987; FORATTINI et al. 1972, 1973; MAGALHĀES ROCHA et al. 1988; PETERSON et al. 1988; GOMES 1992; VASCONCELOS et al. 1994);

- a ocorrência de Bichromomyia flaviscutellata (Mangabeira, 1942), o vetor da leishmaniose cutâneo-difusa, na Serra da Bodoquena (NUNES 2001);

- a implementação do ecoturismo para a região sudoeste de MS, principalmente, para as áreas de cavernas e de rios que cortam o Planalto da Bodoquena (NUNES 2001; GALATI et al. 2003a); 
- a alta taxa de migração em MS, com ênfase para a intensificação dos assentamentos de trabalhadores rurais sem terra na região sudoeste do Estado;

- a ocorrência da leishmaniose visceral canina no Assentamento Guaicurus, do INCRA, município de Bonito, MS (NUNES 2001);

- a ocorrência de casos de LTA em moradores do Assentamento Guaicurus e de áreas adjacentes, são urgentes os estudos sobre a relação parasita (s) - vetor (es) - homem reservatório(s), para identificar os fatores que contribuem para a transmissão das leishmanioses em áreas do sudoeste do Estado de Mato Grosso Sul, de modo a fornecer subsídios aos responsáveis pelas açōes de saúde local para uma política de intervenção, visando o controle das leishmanioses, baseados no conhecimento dos componentes bio-ecológicos das diversas populações envolvidas nessas parasitoses e também alertar os órgãos locais responsáveis pelo turismo e assentamentos de trabalhadores rurais sem terra, sobre os possiveis riscos de transmissão de leishmanioses no sudoeste sul-matogrossense. 


\section{OBJETIVOS}

\subsection{Objetivo Geral}

Estimar a taxa de infecção por protozoários do gênero Leishmania em populações de animais domésticos e de vetores e ampliar o conhecimento sobre o comportamento da fauna flebotomínea, em ecossistemas do Assentamento Guaicurus, município de Bonito - Estado do Mato Grosso do Sul, no período de outubro de 2002 a outubro de 2003 e analisar esses encontros à luz dos fatores ambientais.

\subsection{Objetivos Específicos}

- Identificar a fauna flebotomínea associada a ecossistemas, tais como: gruta, mata e ambiente antrópico.

- Observar a diversidade, índice de abundância e sazonalidade para as espécies de flebotomíneos da área.

- Verificar a distribuição espacial dos flebotomíneos no Assentamento Guaicurus.

- Investigar infecção natural por leishmânias, em fêmeas de flebotomíneos capturadas em ambientes antrópicos e silvestres, por meio de técnicas parasitológicas e moleculares.

- Identificar possíveis espécies vetoras de LTA ou LVA no Assentamento Guaicurus. 
- Comparar as taxas de infecção natural por leishmânias nos flebotomineos encontrados no domicílio, peridomicilio, mata e cavernas.

- Verificar a prevalência de anticorpos anti-Leishmania em animais domésticos (cães e eqüinos).

- Comparar a técnica de imunofluorescência indireta e ensaio imunoenzimático para diagnóstico sorológico da leishmaniose visceral em cães por meio de soro e sangue em papel filtro.

- Verificar que espécies de Leishmania estão ocorrendo em cães e eqüinos, por meio de técnicas parasitológicas e moleculares.

- Identificar o padrão de transmissão das leishmanioses no Assentamento Guaicurus. 


\section{MATERIAL E MÉTODOS}

\subsection{Descrição da área de estudo}

\subsubsection{Aspectos gerais do Planalto da Bodoquena}

A unidade geomorfológica denominada Planalto da Bodoquena encontra-se na parte centro-sul do Estado do Mato Grosso do Sul, como um extenso divisor de águas entre a Bacia do Rio Paraguai, a oeste e as subbacias do Apa, ao sul e do Miranda, a leste (Figura 1). 


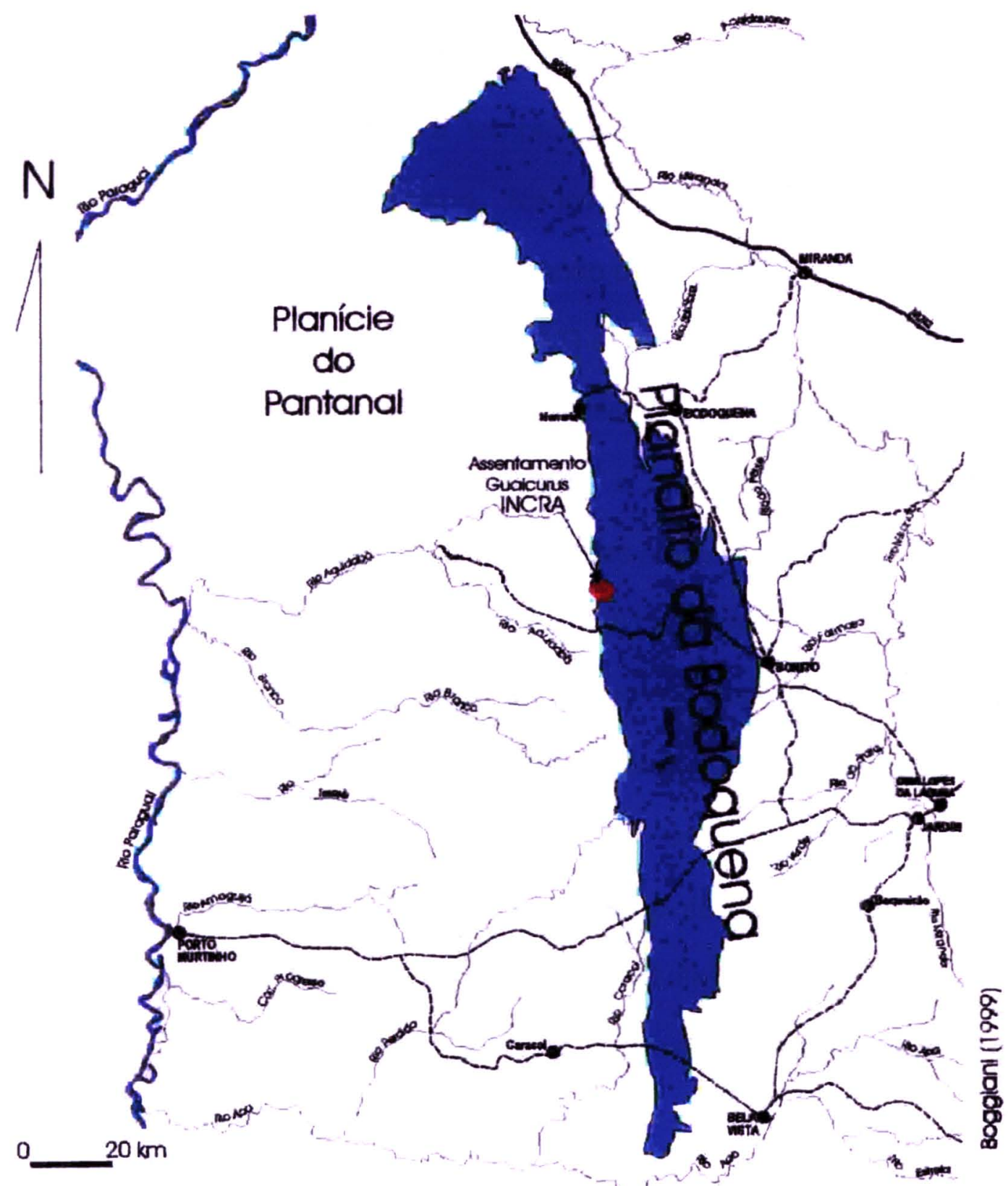

Figura 1 - Localização do Assentamento Guaicurus no Planalto da Bodoquena, Mato Grosso do Sul .

Compreende um conjunto de relevos serranos, dispostos na direção norte-sul, de caráter residual, por se encontrar circundado pela depressão do Rio Paraguai, onde o bloco mais representativo é formado pela Serra da Bodoquena (ALVARENGA et al. 1982). 
A Serra da Bodoquena, considerada um planalto calcário, estende-se por, aproximadamente, $200 \mathrm{~km}$ de comprimento e $65 \mathrm{~km}$ de largura. Seu clima é basicamente tropical, a temperatura média anual é $22^{\circ} \mathrm{C}$ e a precipitação média é $1450 \mathrm{~mm} / a n o$. No inverno, por influência de massas polares, as chuvas não são intensas variando de 30 a $60 \mathrm{~mm} / \mathrm{mês}$, ficando o ambiente mais seco (NUNES 2001; GALATI et al. 2003b).

A Serra da Bodoquena é um ecossistema único, onde há a confluência entre o Pantanal, os cerrados, o chaco e a Mata Atlântica, abrigando grande biodiversidade, com espécies exclusivas da região, muitas das quais ameaçadas de extinção (NUNES 2001; GALATI et al. 2003b).

A exploração de recursos naturais de acentuadas belezas cênicas e de inúmeros locais que permitem múltiplas atividades de lazer fizeram do sudoeste sul-mato-grossense um importante polo-turistico nacional e internacional. Assim, para tentar frear o processo de degradação que vem sofrendo, foi criado em 2000 o Parque Nacional da Serra da Bodoquena, com 76,4 mil hectares que tem auxiliado o desenvolvimento sustentado da região, dando suporte ao turismo (NUNES 2001).

\subsubsection{Caracteristicas locais do Assentamento Guaicurus}

O Assentamento Guaicurus está situado na parte central da Serra da Bodoquena, a $20^{\circ} 27^{\prime}$ LS e $56^{\circ} 52^{\prime} \mathrm{LW}$, pertencente ao municipio de Bonito, MS, dista $68 \mathrm{~km}$ da sede do mesmo. Implantado pelo INCRA, na década de 80, em uma área de 2772 hectares compreende a sede e 131 lotes 
dispostos em cinco linhas: Agrovila, Campina, Poção, Quatorze e da Sede que é um trecho de uma estrada estadual (Figura 2).

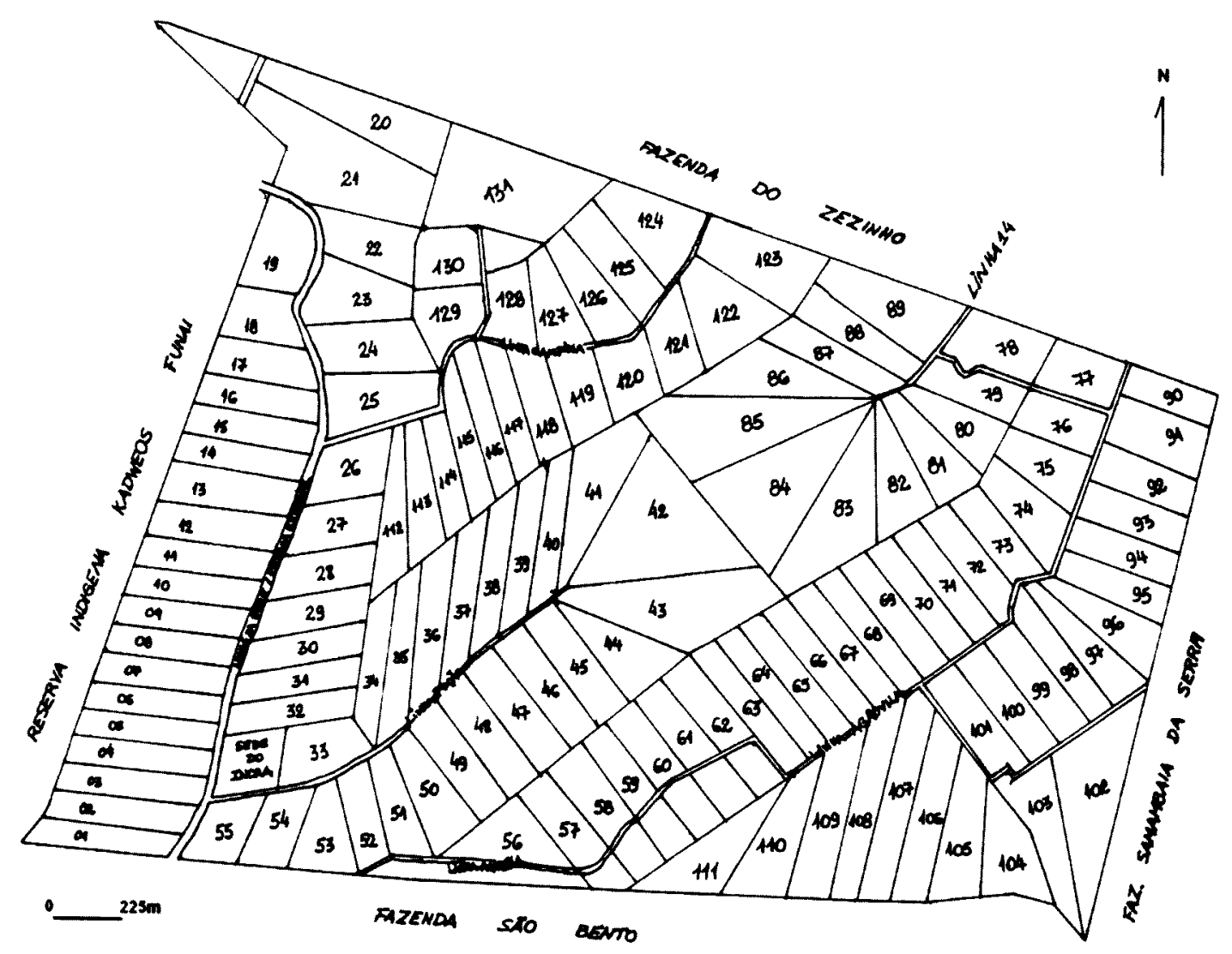

Figura 2 - Mapa do Assentamento Guaicurus, Bonito - MS.

A cobertura vegetal primitiva é formada, principalmente, em áreas de solo raso por floresta estacional semidecidual submontana (VELOSO et al. 1991) e encontra-se, relativamente, preservada nos niveis topográficos mais elevados, onde são encontradas, ainda madeiras de lei.

Os vales foram totalmente desmatados para a construção das moradias, cultivo de lavouras de subsistência e plantio de capim para criação de bovinos em pequena escala (NUNES 2001; GALATI et al. 2003b). 
A estrada que liga a cidade de Bonito ao Assentamento Guaicurus, mesmo, sem pavimentação asfáltica e de conservação precária, permite o tráfego em todas estações do ano, o mesmo acontecendo com as vias que cortam o loteamento.

Da fauna de mamiferos silvestres no Assentamento relatada pelos moradores constam espécies como: lobinho, cutia, cateto, queixada, tatu, veado, macaco, quati, roedores, lebre e anta (NUNES 2001).

\subsection{Inquérito de animais domésticos}

\subsubsection{População em estudo}

O projeto, após submissão ao comitê de ética em pesquisa da Faculdade de Saúde Pública da Universidade de São Paulo (FSP/USP) (anexo 1), teve inicio com visitas domiciliares aos moradores do Assentamento Guaicurus, no final de fevereiro e primeira quinzena de março de 2003, com a finalidade de pesquisar cães (Canis familiaris) e cavalos (Equus caballus) existentes nas propriedades. Nas residências onde havia esses animais, esclareceu-se o objetivo do estudo e solicitou-se o consentimento dos proprietários para coleta de sangue dos mesmos.

Os animais foram examinados observando-se o seu estado geral e manifestações clínicas sugestivas de leishmaniose visceral ou tegumentar.

Dos 131 lotes existentes no Assentamento, estavam habitados 76 $(58,0 \%)$ e foram colhidas amostras de sangue de cães e/ou cavalos em 58 deles $(76,3 \%)$. Em relação aos 18 lotes restantes, em 9, não haviam esses 
animais e nos demais, o proprietário não autorizou a coleta ou por outros motivos, não foi possivel executá-la.

\subsubsection{Colheita de sangue - primeira amostra}

As amostras de sangue foram colhidas por punção da veia safena ou jugular com agulha $30 \times 8 \mathrm{~mm}$, nos cães e da jugular, com agulha $40 \times 12$ $\mathrm{mm}$ nos eqüinos. $O$ sangue permaneceu em repouso para retração do coágulo, por tempo variável, sendo então centrifugado a 2500 r.p.m., por cinco minutos, para obtenção do soro.

Alíquotas do sangue colhido dos cães foram colocadas em papel filtro Whatman $n^{\circ} 1$ que foi seco à temperatura ambiente.

As amostras de sangue em papel filtro e soro foram encaminhadas, devidamente identificadas e acondicionadas em caixas de isopor com gelo, para o Laboratório de Zoonoses e Doenças Transmitidas por Vetores da Vigilância em Saúde da Prefeitura do Município de São Paulo (LabZoo-VIS), onde foram estocadas $\mathrm{a}-20^{\circ} \mathrm{C}$, até o processamento.

As amostras de soro dos eqüinos foram testadas pela reação de imunofluorescência indireta (RIFI).

As amostras de sangue em papel filtro e soro dos cães foram processadas por meio da reação de imunofluorescência indireta e do ensaio imunoenzimático (EIE). 


\subsubsection{Colheita de aspirado medular e segunda amostra de sangue}

Em junho de 2003, foram colhidos aspirados de medula óssea e novas amostras de sangue de animais que apresentaram resultados reagente ou inconclusivo, em pelo menos uma das técnicas sorológicas.

Aspirados de medula óssea foram colhidos da porção proximal da tíbia, com agulha $40 \times 12 \mathrm{~mm}$. A seguir, para a pesquisa do parasita pelos métodos convencionais, foram feitos esfregaços em lâminas, semeadura em meio de cultura acelular e inoculação em hamster Mesocricetus auratus. Os esfregaços e tubos de cultura foram encaminhados para o LabZoo-VIS e os hamsters para o Laboratório de Parasitolcgia da Universidade para o Desenvolvimento do Estado e da Região do Pantanal (UNIDERP).

O sangue foi colocado em papel filtro, em tubo seco para obtenção do soro e em tubo com anticoagulante EDTA para obtenção do creme leucocitário.

As amostras de sangue em papel filtro e soro foram utilizadas para confirmação da reatividade.

O creme leucocitário foi separado do sangue por centrifugação a 3000 r.p.m. por dez minutos, em centrífuga Celm $\circledast$ - Combate. Aliquota do aspirado medular foi colocada em microtubo contendo tampão NET (150 $\mathrm{mM} \mathrm{NaCl}, 50 \mathrm{mM}$ EDTA, $100 \mathrm{mM}$ Tris-HCl pH 7,5), assim como o creme leucocitário. Ambos materiais foram mantidos em geladeira, transportados em isopor com gelo e armazenados no LabZoo-VIS em freezer $-20^{\circ} \mathrm{C}$, como descrito por REITHINGER et al. 2000. 
Essas amostras foram obtidas para detecção de DNA do parasita por meio da reação em cadeia da polimerase (PCR) e identificação da espécie com o emprego da técnica de seqüenciamento, junto ao Instituto de Ciências Biomédicas da Universidade de São Paulo (ICB /USP).

\subsubsection{Pesquisa de anticorpos anti-Leishmania}

\subsubsection{Reação de imunofluorescência indireta (RIFI)}

As amostras foram testadas frente aos antigenos obtidos a partir de promastigotas das cepas de referência L. (L.) amazonensis (IFLA/BR/67/PH8), L. (V.) braziliensis (MHOM/BR/75/M2904) e L. (L.) chagasi (MCER/BR/81/M6445), mantidas conforme descrito por SAN MARTIN-SAVANI (1998) e os antígenos preparados segundo GUIMARÃES et al. (1974).

Os soros dos eqüinos e dos cães, assim como os seus respectivos controles positivo e negativo, foram diluidos a 1:20 em solução salina tamponada pH 7,2 (SST) e depositados em áreas delimitadas nas lâminas previamente impregnadas com cada um dos antigenos, assim cada amostra foi colocada em 3 lâminas.

As lâminas foram incubadas em câmara úmida a $37^{\circ} \mathrm{C}$ por 30 minutos. A seguir, foram lavadas em dois banhos de SST de 10 minutos cada. Após a secagem, em temperatura ambiente, foi acrescentado antigamaglobulina total de cão ou anti-gamaglobulina total de eqüino (produzidos pelo LabZoo-VIS), marcados com isotiocianato de fluoresceina, 
diluidos a 1:200 e 1:50, respectivamente, em azul de Evans $4 \mathrm{mg} \%$. As lâminas foram novamente incubadas e lavadas como descrito acima.

As lâminas secas foram montadas com glicerina tamponada $\mathrm{pH} 8,0 \mathrm{e}$ laminula, sendo a leitura efetuada em microscópio de imunofluorescência (Axioskop da Zeiss $®$ ) com aumento de 40X.

Foram consideradas reagentes, as amostras que apresentaram as promastigotas fluorescentes, inclusive no flagelo, e não reagentes, as amostras que apresentaram $\circ$ parasita sem fluorescência com cor avermelhada.

Os soros reagentes foram novamente testados, para determinar o título de anticorpos presentes na amostra, em diluiçōes seriadas na razão 2 a partir da diluição 1:20, ou seja, 1:40, 1:80, 1:160, 1:320; 1:640 e assim por diante até a última diluição em que as formas promastigotas apresentaram fluorescência.

Foram consideradas reagentes as amostras que apresentaram titulo igual ou maior a 40 . Nos soros em que existiram diferenças de titulo frente as três cepas de antígeno testadas, o título foi determinado pela reação frente ao antígeno de $L$. (L.) chagasi, visto este apresentar menos reações cruzadas com outros tripanossomatídeos (BADARÓ et al. 1983).

As amostras de sangue dos cães em papel filtro Whatman $n^{\circ} 1$ foram eluidas, colocando-se dois círculos de $6 \mathrm{~mm}$ de diâmetro em $160 \mu \mathrm{l}$ de solução salina tamponada, deixando na geladeira "overnight". Posteriormente, foram testadas como descrito anteriormente. As amostras eluídas equivalem a uma diluição 1:40. 


\subsubsection{Ensaio imunoenzimático (EIE)}

Os soros e os eluatos sanguineos dos cães foram testados por meio do kit de EIE para leishmaniose canina produzido pelo Instituto BioManguinhos da Fundação Oswaldo Cruz. Os ensaios foram realizados conforme protocolo que acompanha o kit.

As amostras de soros dos animais e os soros controles positivo e negativo do teste foram diluídos, em diluente de amostra acrescido de lectina de leite e adicionados na microplaca previamente adsorvida com antígenos solúveis e purificados de Leishmania (complexo L. donovani), obtidos a partir de meio de cultura.

A seguir, a placa foi incubada a $37^{\circ} \mathrm{C}$ por 30 minutos e posteriormente lavada, em equipamento automático (Columbus Washer - TECAN\&), por 6

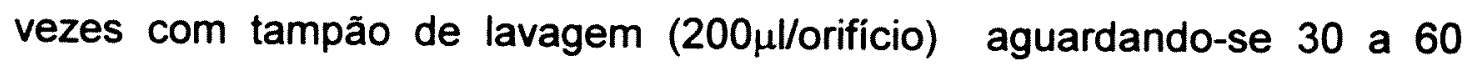
segundos entre cada lavagem. Em seguida, foi colocada uma antigamaglobulina de cão marcada com a enzima peroxidase e a microplaca foi novamente incubada e lavada.

Então, foi adicionado o substrato peróxido de hidrogênio $\left(\mathrm{H}_{2} \mathrm{O}_{2}\right)$ acrescido do cromógeno tetra-metilbenzidine (TMB) e a microplaca foi incubada à temperatura ambiente por 30 minutos, em local abrigado da luz.

Posteriormente, a reação foi bloqueada com ácido sulfúrico $2 \mathrm{M}$ e a leitura efetuada em comprimento de onda de $450 \mathrm{~nm}$ (SPECTRA® III). 
O valor de corte da reação, para determinar as amostras reagentes e não reagentes, foi calculado pela média das absorbâncias dos controles negativos multiplicada por 2 .

As amostras de sangue dos cães colhidas em papel filtro Whatman $n^{\circ}$ 1 foram eluídas em tubos, colocando-se dois circulos de $6 \mathrm{~mm}$ e $400 \mu \mathrm{l}$ do diluente de amostra, deixando-os sob leve agitação rotacional por uma hora e a seguir foram processadas, conforme descrito anteriormente.

O cálculo do valor de corte da reação, neste caso, foi a média das absorbâncias dos controles negativos multiplicada por 3 .

A zona cinza da reação foi determinada entre o valor de corte e o valor obtido pela multiplicação deste por 1,2. As amostras de soro e sangue em papel filtro, que se apresentaram nesta faixa, foram retestadas. Aquelas que permaneceram na zona cinza foram consideradas inconclusivas.

As amostras de soro e de sangue em papel filtro dos cães, que não apresentaram resultados concordantes entre as duas técnicas sorológicas, foram testadas pelo menos mais uma vez por meio da RIFI e do EIE para confirmação dos resultados.

\subsubsection{Pesquisa parasitológica de Leishmania}

Os esfregaços de aspirado de medula óssea foram fixados com metanol por 2 minutos e corados pelo Giemsa por 1 hora. As lâminas foram observadas ao microscópio óptico (Axiolab - Zeiss $®$ ), com aumento de 100X em imersão com óleo, para pesquisa de formas amastigotas. 
As amostras de aspirado de medula semeadas em meio de cultura Blood Agar Base (WALTON et al. 1977) foram mantidas a $23^{\circ} \mathrm{C}$ em estufa incubadora B.O.D. modelo 347-CD (Fanem()). As culturas foram observadas, semanalmente, a partir do $5^{\circ}$ até $\circ 30^{\circ}$ dia, para pesquisa de promastigotas.

Os hamsters (Mesocricetus auratus) infectados com uma aliquota do aspirado medular foram examinados, semanalmente, a fim de observar sinais de leishmaniose. Esses animais foram necropsiados após 4 a 5 meses da inoculação e fragmentos de baço e fígado foram semeados em meio de cultura, como descrito anteriormente, para tentar isolar o parasita.

As promastigotas isoladas em culturas foram encaminhadas ao Instituto Evandro Chagas em Belém, Pará, a fím de serem identificadas, conforme descrito por SHAW et al. (1989), por meio da reação de imunofluorescência frente a 23 anticorpos monoclonais.

\subsubsection{Detecção molecular de Leishmania}

\subsubsection{Extração de DNA}

O DNA foi extraído segundo o protocolo descrito por ULIANA et al. (1991).

As amostras de aspirado de medula e creme leucocitário dos cães foram centrifugadas por 5 minutos a $12000 \mathrm{rpm}$ (Centrifuga CR 3i JOUANQ, rotor AC 2.14). O sobrenadante foi desprezado e o sedimento, acrescido de $500 \mu \mathrm{l}$ de $1 \mathrm{X}$ solução salina tamponada $\left(7 \mathrm{mM} \mathrm{Na} \mathrm{HPO}_{4}, 26\right.$ 
$\mathrm{mM} \mathrm{NaH}{ }_{2} \mathrm{PO}_{4}, 130 \mathrm{mM} \mathrm{NaCl}$ ), foi homogeneizado, novamente centrifugado e o sobrenadante retirado. Este procedimento de lavagem foi realizado por cinco vezes.

Finalmente, o sedimento foi ressuspendido em $200 \mu \mathrm{l}$ de TE $(10 \mathrm{mM}$ Tris $\mathrm{pH} 7,5,1 \mathrm{mM}$ EDTA $\mathrm{pH} 8,0$ ), homogeneizado e macerado. Foram adicionados $1 \%$ de Sódio-dodecil-sulfato (SDS) e $100 \mu \mathrm{g} / \mathrm{ml}$ de pronase. A amostra foi levemente homogeneizada e incubada a $42^{\circ} \mathrm{C}$ por duas horas.

A seguir, foi acrescentado à amostra um volume da mistura fenol:clorofórmio:álcool isoamilico (25:24:1), a mistura foi homogeneizada cuidadosamente, e centrifugada a $13523 \mathrm{~g}$ por 5 minutos em centrifuga refrigerada. A fase aquosa, retirada tendo-se o cuidado de não perturbar a interface, foi colocada em novo microtubo, ao qual foi adicionado, novamente, igual volume da solução de fenol/clorofórmio/álcool isoamílico, seguindo o mesmo procedimento por mais duas vezes.

Em seguida, foi acrescentado à amostra 1 volume de clorofórmio com álcool isoamilico (24:1), centrifugado e a fase aquosa retirada para novo microtubo. Este procedimento, também, foi realizado por três vezes.

À fase aquosa resultante foram adicionados acetato de sódio $0,3 \mathrm{M} \mathrm{e}$ 2,5 volumes de álcool etílico absoluto gelado, levando-se ao freezer $-20^{\circ} \mathrm{C}$ "overnight".

A amostra foi centrifugada sob refrigeração por 10 minutos a $13523 \mathrm{~g}$ e o precipitado foi lavado com $500 \mu$ de álcool etilico (70\%) gelado.

O precipitado, depois de seco à temperatura ambiente foi ressuspendido em $20 \mu \mathrm{l}$ de TE e mantido em geladeira, até a realização da 
PCR. As amostras de DNA foram testadas puras ou diluídas a 1:5 ou 1:10 em TE.

\subsubsection{Reação em cadeia da polimerase (PCR)}

Foram utilizados os oligonucleotídeos S4 (5'- GAT CCA GCT GCA GGT TCA CC -3') e $\$ 12$ (5'- GGT TGA TTC CGT CAA CGG AC -3') descritos em ULIANA et al. (1994), que são complementares a duas regiōes do rDNA que codifica a subunidade $18 \mathrm{~S}$, idênticas em todas as espécies de Leishmania. Estes oligonucleotideos permitiram a amplificação de um fragmento de $520 \mathrm{bp}$.

A PCR foi feita em um volume final de $50 \mu$, contendo tampão da enzima 1X, $2 \mathrm{mM}$ cloreto de magnésio, 0,2 mM deoxinucleotídeos trifosfatos, 0,2 $\mu \mathrm{M}$ de cada oligonucleotídeo, $2 \mathrm{U}$ de Taq DNA polimerase (Invitrogen Recombinant Brazilian) e $2 \mu$ de DNA da amostra (cerca de 20 ng de DNA).

Em cada teste foram incluídos como controle positivo, 40 ng de DNA extraído de promastigotas de $L$. (L.) amazonensis, $L(V$.) guyanensis ou $L$. (V.) braziliensis. O controle negativo foi feito com a adição de água bidestilada autoclavada ou TE, no lugar do DNA.

A reação era iniciada com um ciclo de desnaturação a $94^{\circ} \mathrm{C}$ por 3 minutos, seguindo-se 35 ciclos no termociclador Techgene (Uniscience ${ }^{\circledR}$ ). Os ciclos foram de $94^{\circ} \mathrm{C}$ por 1 minuto, $50^{\circ} \mathrm{C}$ por 1 minuto e $72^{\circ} \mathrm{C}$ por 1 
minuto. Após o término da reação, era feita uma extensão final de 7 minutos a $72^{\circ} \mathrm{C}$.

Os produtos da PCR eram analisados por eletroforese em gel de agarose a 2,0\% em tampão TAE 1 X (40 mM Tris-acetato, 2mM EDTA pH 8,0 ) corado com brometo de etídeo $0,3 \mu \mathrm{g} / \mathrm{ml}$, submetido a uma diferença de potencial de 3 a $5 \mathrm{~V} / \mathrm{cm}$ até que o azul de bromofenol do tampão de amostras $(0,25 \%$ de azul de bromofenol, $0,25 \%$ de xilenocianol, $15 \%$ de ficoll tipo 400) percorresse mais de dois terços do gel. Utilizou-se DNA do fago Lambda clivado com a enzima de restrição Hind III ou 1Kb DNA ladder (Gibco-BRL), como padrão de tamanho molecular. As bandas foram observadas sob luz ultravioleta e registradas em câmara fotográfica Kodak ds ou Eagleeye II - Stratagene®.

\subsubsection{3 "Nested" - PCR}

Os oligonucleotideos S4 e S12 são complementares a seqüências conservadas da subunidade $18 S$ do DNA ribossômico, amplificando assim, seqüências que podem ser encontradas em outros tripanossomatideos. Como nas amostras analisadas, havia a possibilidade de existirem outros tripanossomatideos, tais como Trypanosoma evansi, foi feita uma segunda PCR, utilizando como molde o produto da primeira, com um par de oligonucleotídeos (S17 e S18) específicos para o gênero Leishmania (dados não publicados). 
Essa segunda reação, executada num termociclador Genius (Uniscience ${ }^{\circledR}$ ) com um ciclo de $94^{\circ} \mathrm{C}$ por 4 minutos, 30 ciclos de $94^{\circ} \mathrm{C}$ por 1 minuto, $55^{\circ} \mathrm{C}$ por 1 minuto e $72^{\circ} \mathrm{C}$ por 30 segundos, seguiu as mesmas condiçōes descritas anteriormente, utilizando como DNA alvo $1 \mu \mathrm{da}$ primeira reação com S4 e S12. O produto da PCR foi analisado, conforme descrito anteriormente. Nessa PCR o fragmento amplificado é de cerca de $490 \mathrm{bp}$.

\subsubsection{Purificação de produto da PCR}

Todo o produto da PCR com S17 e S18 foi purificado pelo método descrito por ZHEN e SWANK (1993), como resumido a seguir. Após a eletroforese em gel de agarose $2 \%$, o gel foi recortado retirando-se um pequeno bloco da região abaixo da banda de DNA, acrescentando-se polietilenoglicol (PEG 6000) a 15\%. Nessa canaleta, o DNA foi eletroeluído, aplicando-se uma corrente de 120 volts em cuba de eletroforese com tampão TAE $1 \mathrm{X}$.

Após a saida do DNA do gel, monitorado por observação do gel em luz ultravioleta, a solução de PEG contendo o DNA foi retirada e colocada em microtubo tipo "eppendorf". Eram feitos duas extrações de traços de agarose do DNA, com um volume de clorofórmio: álcool isoamílico (24:1). O DNA era precipitado com 0,1 volume de acetato de sódio $0,3 \mathrm{M}$ e 1 volume de isopropanol absoluto à temperatura ambiente. Após centrifugação, o 
DNA precipitado foi lavado com $500 \mu \mathrm{l}$ de álcool etílico (70\%) gelado e depois de seco à temperatura ambiente foi ressuspendido em $10 \mu \mathrm{l}$ de TE.

O fragmento de DNA purificado era quantificado por meio de eletroforese em gel de agarose, comparando-se o tamanho da banda da amostra com a do padrão 1Kb DNA (Biolabs), e mantido em geladeira, até a realização da reação de seqüenciamento.

\subsubsection{Seqüenciamento de DNA}

A reação de seqüenciamento foi realizada empregando-se "DNA Sequencing Kit - Big Dye ${ }^{\mathrm{TM}}$ Terminator $\vee 3.0$ Cycle Sequencing - Applied Biosystems" (ABI Prism), onde se utilizou $0,16 \mu \mathrm{M}$ do oligonucleotídeo S18 e 10 a $20 \mathrm{ng}$ do fragmento de interesse, como descrito por SANGER et al. (1977).

As seqüências de nucleotideos foram determinadas automaticamente em aparelho 3700 DNA Analyzer (ABI Prism), analisadas e alinhadas por meio do programa de computador BioEdit (HALL 1999), e comparadas com as seqüências de nucleotídeos de Leishmania (L.) amazonensis, L. (V.) braziliensis, L. (V.) guyanensis, L. (L.) chagasi, L. (L.) donovani, Trypanosoma cruzi e Trypanosoma evansi, disponiveis no GeneBank. 


\subsection{Inquérito sobre flebotomineos}

\subsubsection{Capturas com armadilhas luminosas, tipo CDC, com inseticida}

- Sitios de captura

Os sítios de captura de flebotomíneos compreenderam diferentes ambientes de lotes, onde foram diagnosticados casos de LVA em cães, situados ao longo de todas as Linhas do Assentamento Guaicurus (NUNES et al. 2001).

Na Linha Campina abrangeu área de mata de encosta bastante alterada situada nas encostas de um morro, domicilio e peridomicilio (pocilga, galinheiro e abrigo de carneiros) do lote 124; área de mata de encosta relativamente preservada situada nas encostas de um morro, domicílio (figuras 3 e 4) e peridomicilio dos lotes $n^{\circ s} 19$ e 20 (figura 5); área de cultivo de subsistência do lote 20 . 


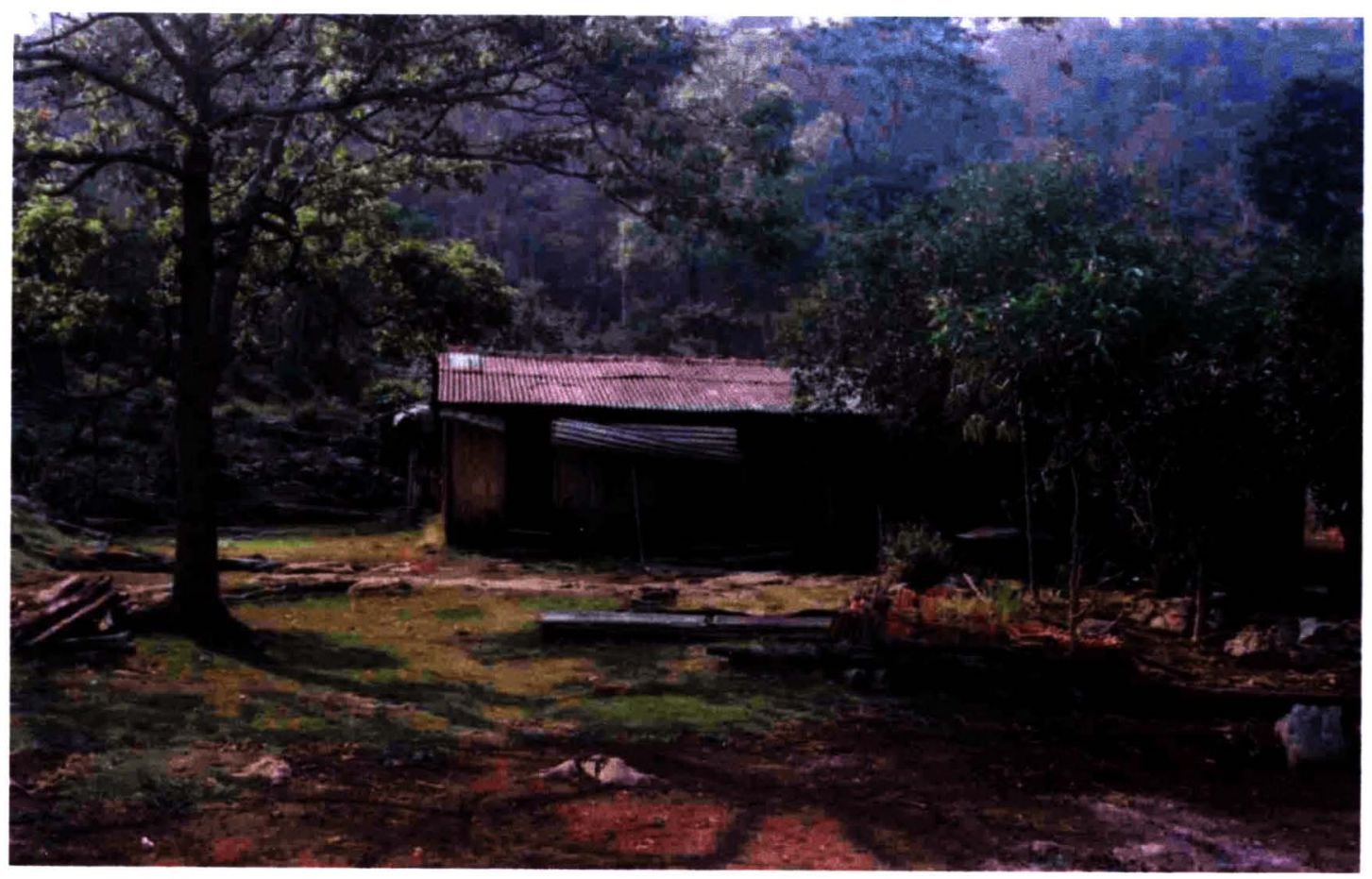

Figura 3 - Vista frontal do domicílio do lote 20 .

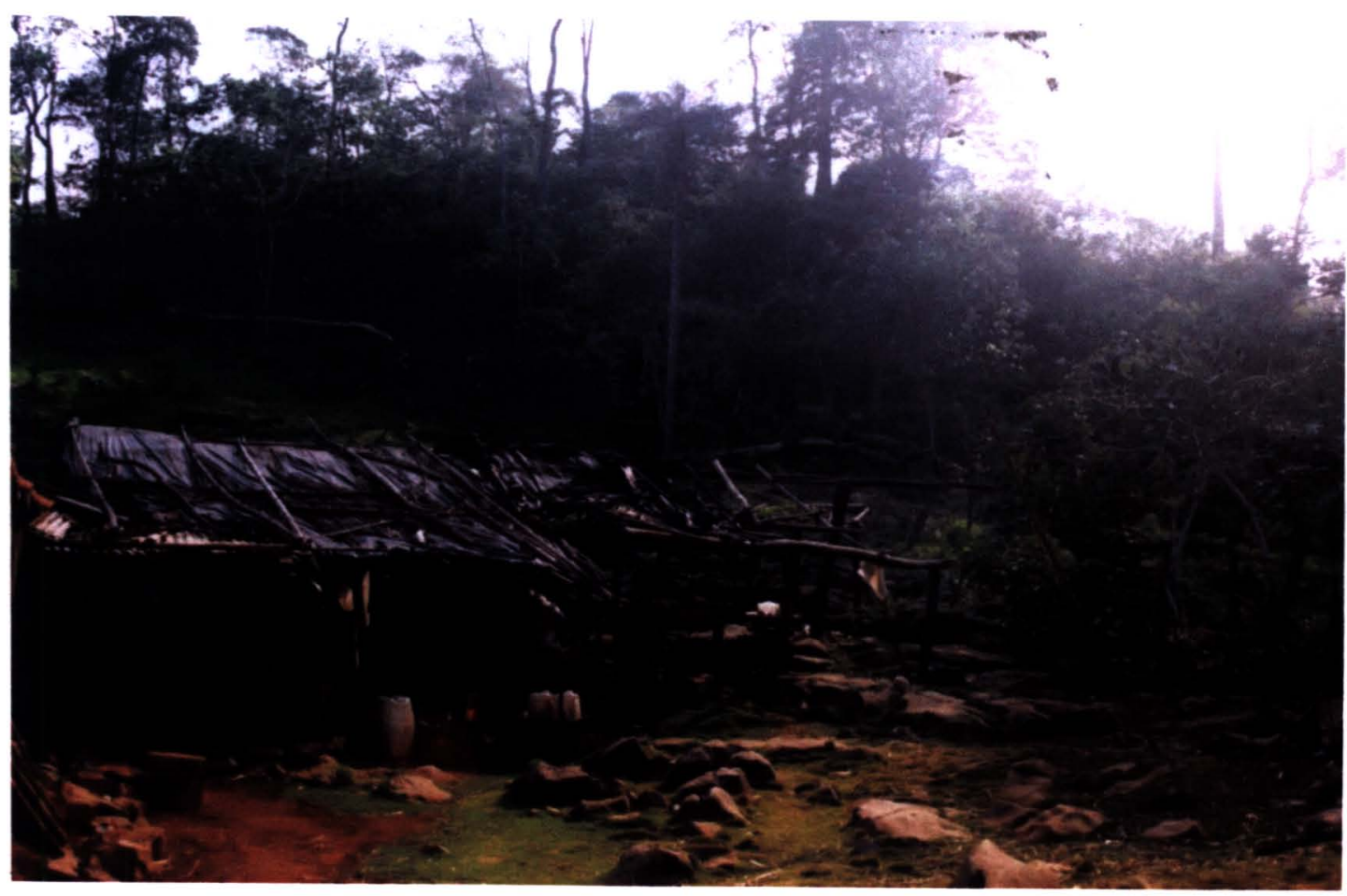

Figura 4 - Vista lateral de parte do domicílio e anexos do lote 20. 


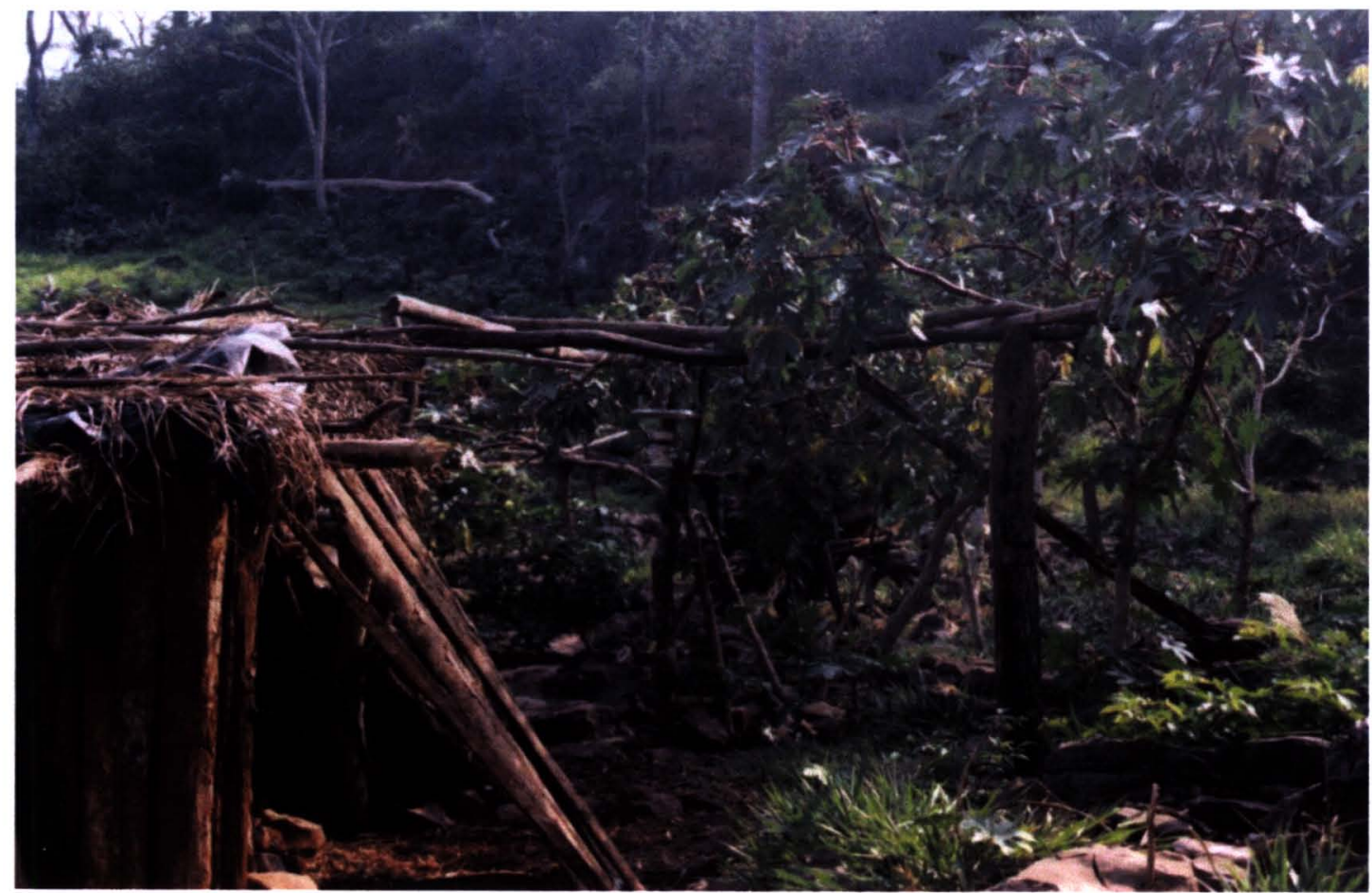

Figura 5 - Aspecto do galinheiro existente no peridomicílio do lote 20.

$\mathrm{Na}$ Linha da Sede incluiu área de mata de encosta bem preservada, domicílio e peridomicílio do lote $\mathrm{n}^{\circ} 02$.

Na Linha do Poção compreendeu o peridomicílio e domicílio do lote 35.

$\mathrm{Na}$ Linha Agrovila abrangeu área de cultivo de subsistência do lote 110, domicílio e peridomicílio dos lotes $\mathrm{n}^{\circ \mathrm{s}} 59,102,110$ e uma gruta (figura 6), conhecida como Gruta do Olímpio, próxima ao lote 56 , situada em uma encosta circundada por área de floresta submontana, relativamente bem preservada. 


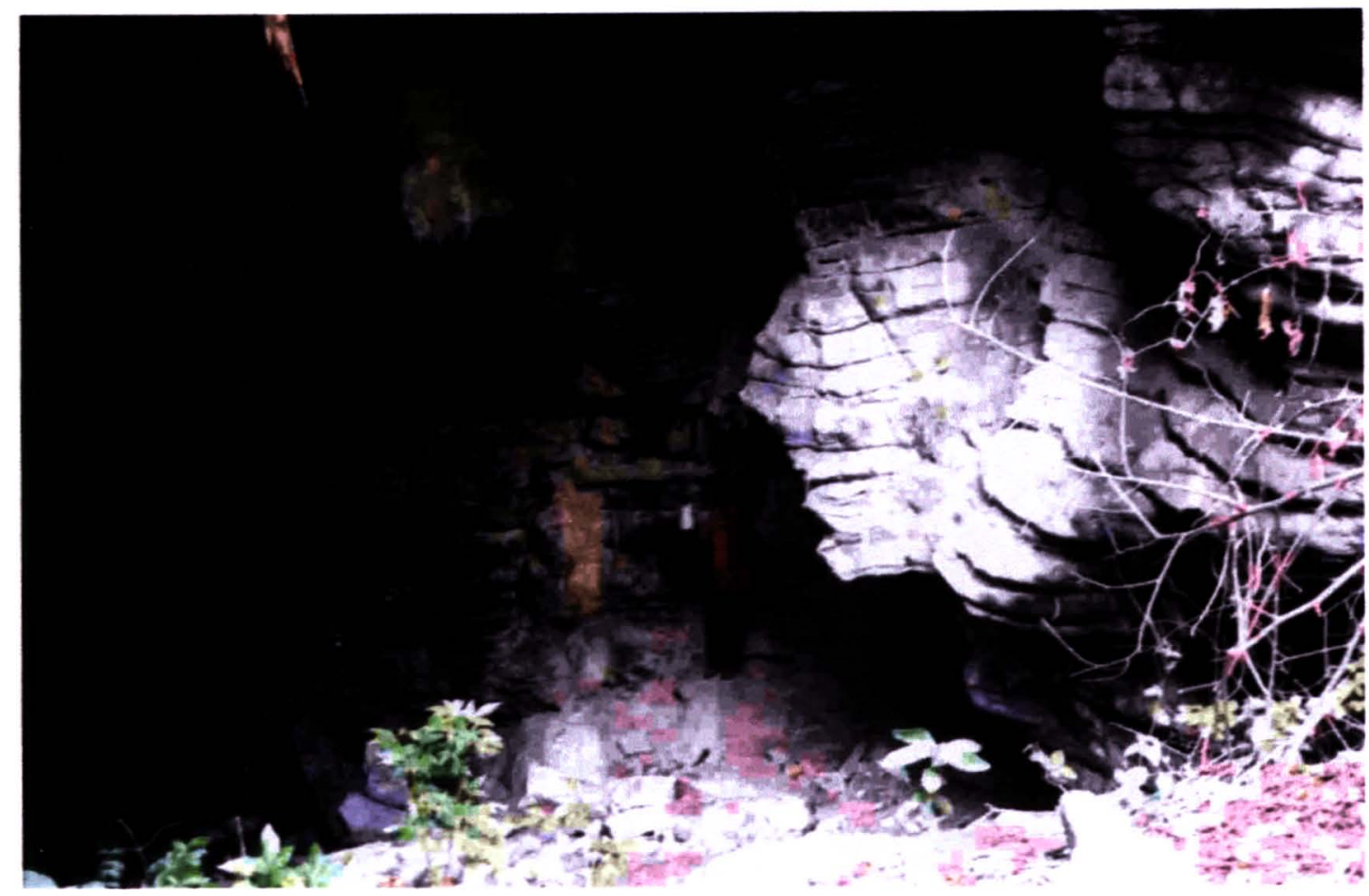

Figura 6 - Aspecto da gruta (Gruta do Olímpio) próxima ao lote 56.

$\mathrm{Na}$ Sede do Assentamento compreendeu o interior e o quintal de uma residência situada nas imediações da escola.

- Técnicas de captura e procedimentos

Os trabalhos iniciaram-se em novembro de 2002 e se estenderam até outubro de 2003.

Foram utilizadas armadilhas luminosas automáticas em miniatura tipo CDC (NATAL et al. 1991) colocando-se no fundo um pedaço de papel filtro com inseticida, dispostas nos pontos de captura por moradores locais quinzenalmente, das $18 \mathrm{~h}: 00$ às $6 \mathrm{~h}: 00$, sem obedecer horários de verão (figura 7). 


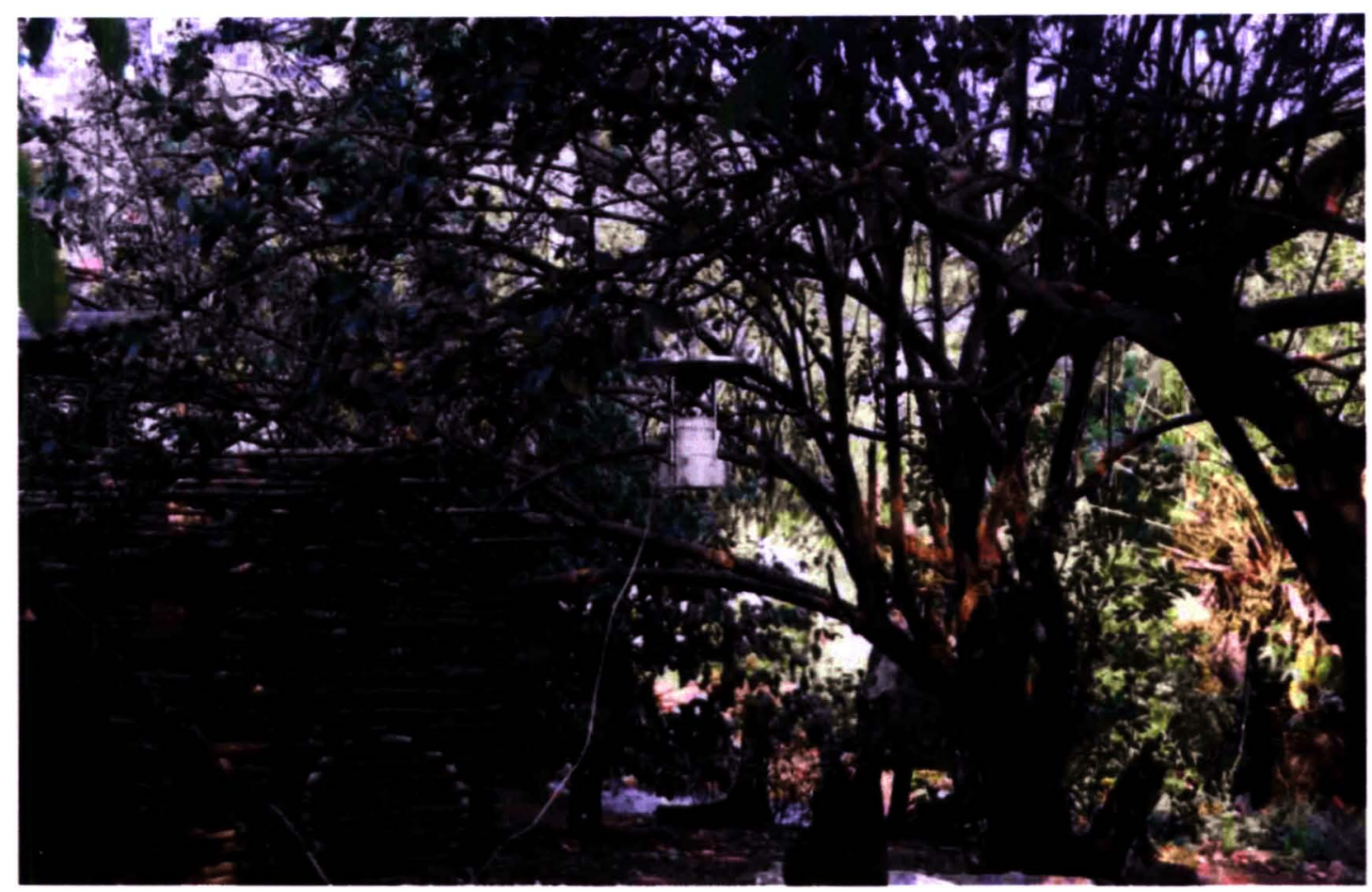

Figura 7 - CDC com inseticida colocada próxima ao galinheiro do lote 02.

Os insetos capturados foram acondicionados em placas de Petri, mantidos em refrigerador até serem enviados para o Laboratório de Phlebotominae do Departamento de Epidemiologia da Faculdade de Saúde Pública da Universidade de São Paulo (FSP/USP) para identificação das espécies. As fêmeas ingurgitadas estão sendo conservadas em congelador para estudo do hábito alimentar.

\subsubsection{Capturas com armadilhas tipo Shannon}

- Sítios de captura

No peridomicílio e no domicílio do lote 20 , peridomicílio dos lotes 02 , 19, 40, 60, 115 e área de cultivo do lote 20. 
- Técnicas de captura e procedimentos

Os trabalhos iniciaram-se em outubro de 2002 e se estenderam até outubro de 2003 , sendo realizadas capturas mensais no intra e peridomicílio do lote 20 e esporádicas nos demais sítios de captura: peridomicílio dos lotes 02 (2 capturas), 19 (3), 40 (1), 60(1), 115 (1) e área de cultivo do lote 20 (1).

As capturas aconteceram das $18 \mathrm{~h}: 00$ às $22 \mathrm{~h}: 00$, com a utilização de armadilhas tipo Shannon, na cor preta (GALATI et al. 2001), iluminadas com luz fria, alimentadas por bateria de 12 volts (figura 8).

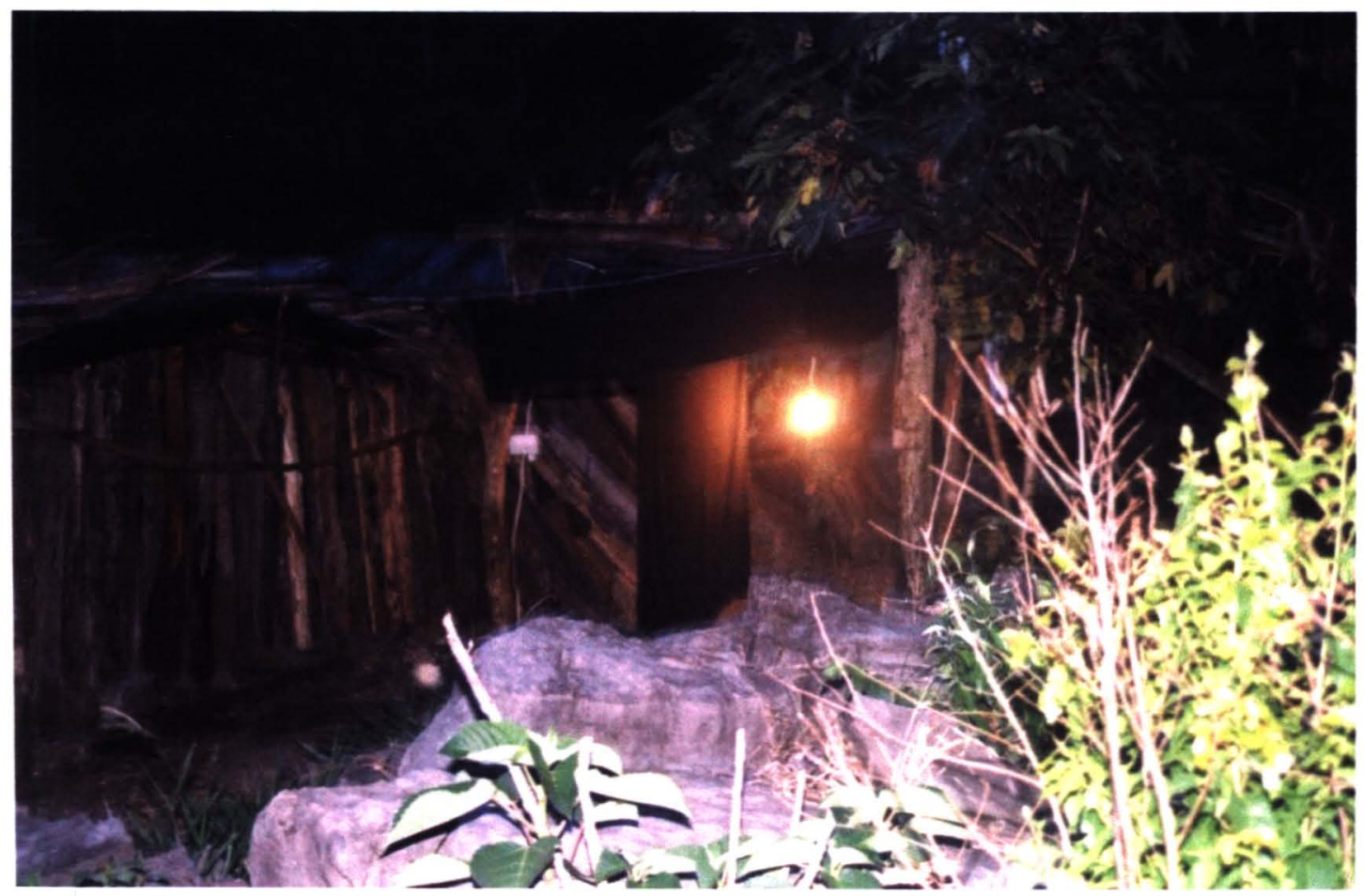

Figura 8 - Armadilha de Shannon colocada próximo ao galinheiro do lote 20.

Os flebotomíneos foram capturados em frascos individuais de polietileno. Os recipientes foram acondicionados em caixa de isopor, 
revestidas internamente por gesso umedecido para garantia da temperatura e da umidade do micro-ambiente, até a chegada do material ao laboratório de campo.

As fêmeas foram dissecadas para verificação de infecção natural por flagelados. Aquelas que não apresentaram condições de dissecção e os machos foram enviados para o Laboratório de Phlebotominae do Departamento de Epidemiologia da FSP/USP para identificação da espécie, a fim de contribuir na investigação da fauna flebotomínea.

\subsubsection{Capturas com armadilhas luminosas automáticas modificadas, tipo CDC, sem inseticida}

Com intuito de capturar maior número de espécimes para investigação de infecção natural por Leishmania e melhor amostragem dos vários ambientes estudados, foram utilizadas, também, armadilhas luminosas modificadas (figura 9). Nesta a câmara coletora é disposta após a ventoinha, com um manguito fazendo sua junção ao corpo do aparelho (GALATI et al. 2003a). 


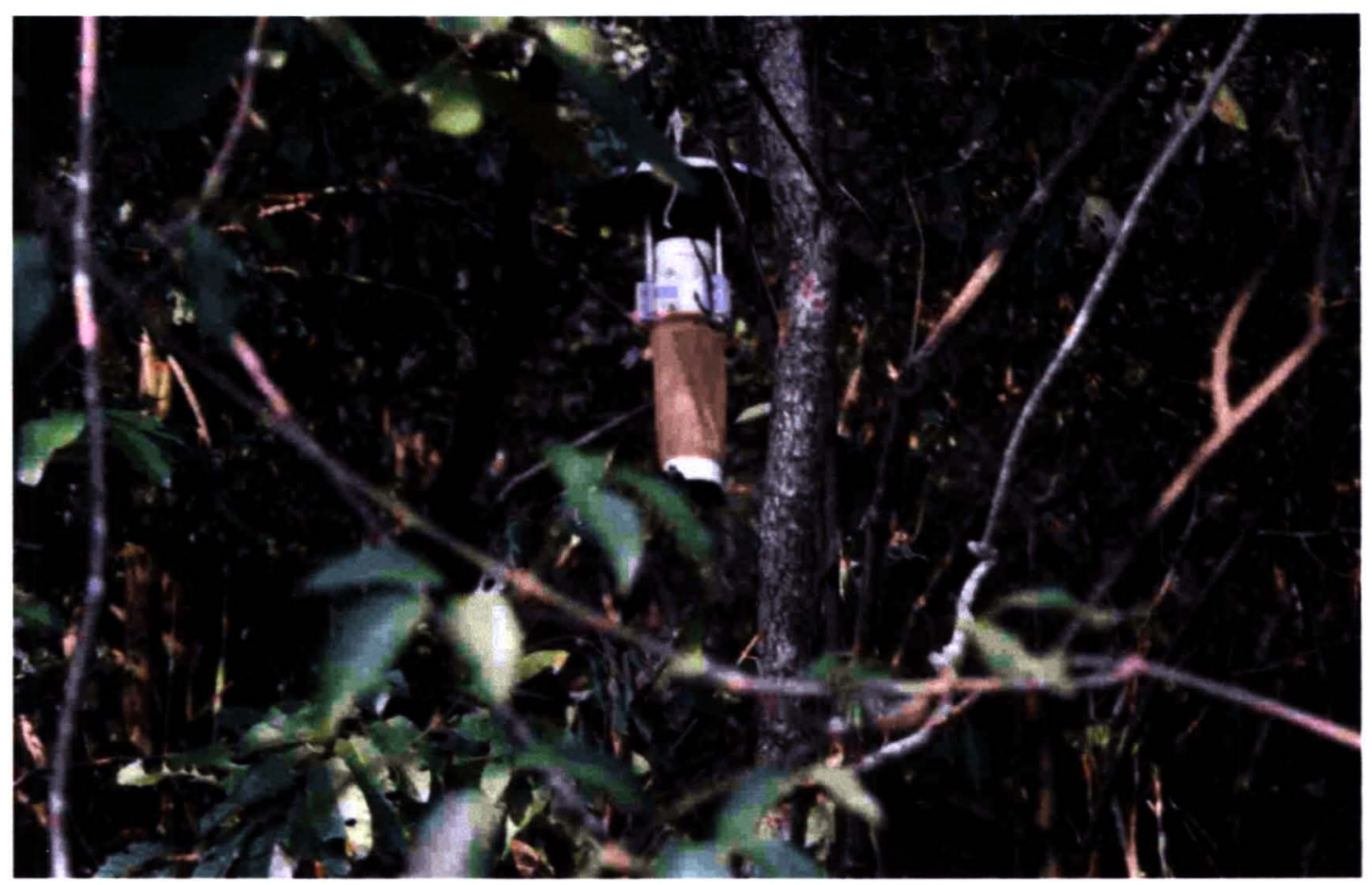

Figura 9 - Armadilha automática luminosa com manguito colocada na mata.

- Sítios de captura

No peridomicílio dos lotes 02 (2 capturas), 19 (15), 20 (25), 40 (1), 59 (1), 60 (2), 110 (3), 115 (7), 121 (1), 124 (1); na área de mata dos lotes 02 (2), 19 (9), 20 (17); na gruta (11) existente na linha Agrovila, próxima ao lote 56 e gruta existente no lote 20 (7); no domicílio do lote 20 (7), 19 (12) e 124 (3); área de cultivo do lote 20(3) e do lote 110 (3).

- Técnicas de captura e procedimentos

As armadilhas foram ligadas por volta de $18 \mathrm{~h}: 00$ e recolhidas às 6h:00. As capturas foram realizadas em outubro de 2002 e mensalmente de abril a outubro de 2003.

As câmaras coletoras foram vedadas e acondicionadas em caixa de isopor para transporte ao laboratório de campo. Neste, as mesmas foram 
abertas em pequenas gaiolas e as fêmeas recapturadas em frascos individuais de polietileno.

As fêmeas foram dissecadas para observação de infecção natural. Os machos e as fêmeas que não apresentaram condições de dissecção foram enviados para identificação da espécie com o objetivo de auxiliar na pesquisa da fauna flebotomínea.

Os lotes do Assentamento Guaicurus, onde foram colocadas uma ou mais das armadilhas descritas anteriormente, encontram-se assinalados na figura 10.

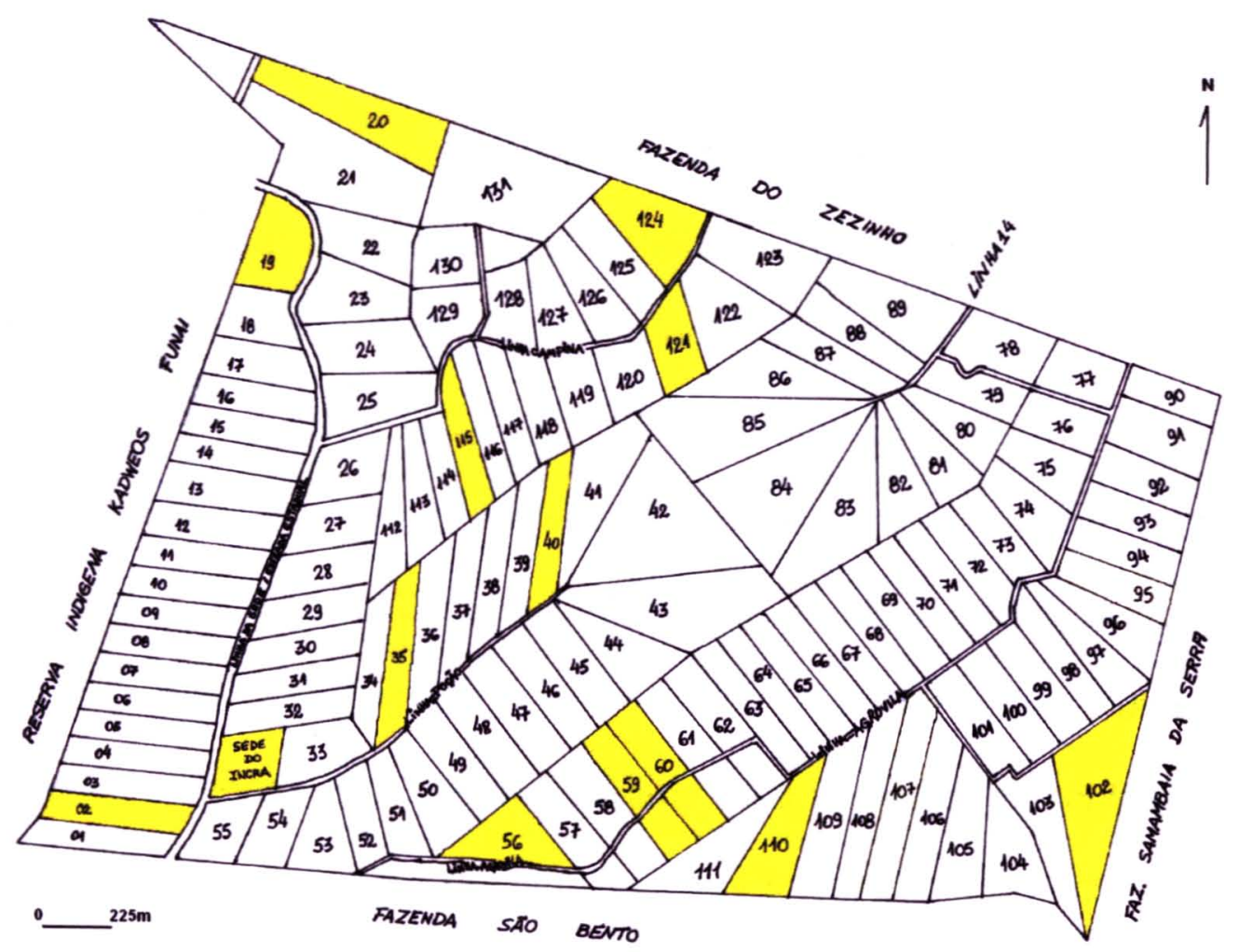

Figura 10 - Mapa do Assentamento Guaicurus, Bonito - MS com a distribuição dos lotes, assinalados em amarelo, onde ocorreram capturas de flebotomíneos. 


\subsubsection{Investigação de infecção natural por Leishmania}

Visando identificar e verificar a infecção natural, a fêmea foi imobilizada com éter etílico e colocada em lâmina seca e estéril para retirada das patas e asas. Então, foi transferida para uma gota de solução fisiológica estéril, onde se completou a dissecção, com exposição do tubo digestivo, para pesquisa de promastigotas e espermatecas, para identificação do flebotomineo.

Aliquota da solução com a fêmea dissecada, que apresentou-se infectada por flagelados ao microscópio, foi semeada em meio de cultura $B A B$ a fim de isolar formas promastigotas do parasita.

As fêmeas dissecadas pertencentes à mesma espécie, capturadas na mesma área e mesmo período foram colocadas no mesmo frasco contendo álcool etilico 70\% (CABRERA et al. 2002) e submetidas à PCR.

O procedimento para extração de DNA do parasita no vetor foi estabelecido junto ao ICB/USP, utilizando-se fêmeas de Lu. longipalpis infectadas, experimentalmente, com Leishmania (L.) amazonensis. 0 protocolo empregado foi o mesmo utilizado para as amostras caninas (item 3.2.6.1), sendo que os lotes de flebotomineos foram lavados somente duas vezes em $1 X$ solução salina tamponada.

Além das PCR's efetuadas utilizando-se o gene SSU como alvo, conforme descrito anteriormente (itens 3.2.6.2 e 3.2.6.3), foi realizada outra reação empregando-se o gene G6PD como seqüência alvo para detectar DNA de Leishmania do subgênero Viannia. 
Essa PCR foi executada, em equipamento Techgene (Uniscience ${ }^{\circledR}$ ), segundo protocolo descrito por CASTILHO et al. (2003), com os oligonucleotideos ISVA (5'- GTC GGT TAT CCT ATT CGG GTC -3' ) e ISVC (5'- ATC ACA ATG ATG GTC AAC GCA C -3' ).

\subsubsection{Análise dos resultados entomológicos}

A nomenclatura dos flebotomíneos seguiu a classificação proposta por GALATI (2003).

O Índice de Abundância de Espécies Padronizado (IAEP) foi calculado conforme ROBERTS e HSI (1979).

A abundância numérica e a distribuição espacial das espécies de flebotomineos, encontradas nos vários tipos de ecótopos de um determinado ponto e período, foram estimadas por meio do índice de Abundância das Espécies (IAE), conforme ROBERTS e HSI (1979), seguindo a fórmula:

$$
I A E=\frac{a+R j}{K}
$$

Onde:

$a=$ número de pontos de captura em que a espécie esteve ausente $\times c$; $c=$ para cada sítio de captura, deve-se distribuir as espécies em postos, que variam de 1 a n (atribuindo-se o valor 1 para a espécie mais freqüente). O c compreenderá o maior valor de $\mathbf{n}$ obtido, considerando todos os sítios, acrescido de 1; 
$R j=$ somatória das posições de cada espécie;

$K=$ número de pontos de captura.

A conversão dos valores obtidos em uma escala entre zero e 1 foi obtida pela fórmula:

$I A E P=\frac{c-I A E}{c-1}$

Neste indice, o valor 1 corresponde à espécie mais abundante e portanto, quanto mais o valor se aproximar de zero, menor a abundância da espécie.

A Média geométrica de Williams (Xw) (HADOW 1954, 1960), foi utilizada para avaliar as atividades das espécies de flebotomíneos mais abundantes, pois esta medida de tendência central reflete a frequência e a regularidade das espécies nas coletas.

A fórmula para cálculo foi:

Média de Williams $=\log (X w+1)=\frac{\sum \log (n+1)}{N}$

Média de Williams $=X w=[\operatorname{antilog}(\log (n+1)]-1$

$N$

Onde $n$ é cada valor de uma série de $N$ observações.

O Índice de Diversidade (D) foi calculado pela fórmula de MARGALEF (1949), conforme SERVICE (1993):

$D=\frac{(s-1)}{\log _{e} N}$ 
Onde:

$s=$ número de espécies de flebotomineos capturadas em um determinado período e ponto;

$N=$ número de espécimes capturados neste mesmo período e tempo.

O cálculo dos índices de abundância e da diversidade das espécies, da média geométrica de Williams e análise da variação sazonal foram efetuados com os dados das capturas com armadilhas automáticas luminosas $(C D C)$ com inseticida efetuadas, quinzenalmente, durante 0 período de novembro de 2002 a outubro de 2003. 


\section{RESULTADOS}

\subsection{Inquérito em animais domésticos}

\subsubsection{Inquérito de eqüinos}

Foram processadas amostras de soro de 53 eqüinos de ambos os sexos, a maioria adultos, sendo que, em geral, apresentavam estado nutricional bom e aparência sadia. Todas as amostras testadas foram não reagentes e ao exame clínico os animais não apresentavam lesões sugestivas de LTA e nem sinais de LVA.

\subsubsection{Inquérito canino}

\subsubsection{Prevalência de anticorpos anti-Leishmania}

Foram examinados 129 cães representando, praticamente, o universo da população canina do Assentamento Guaicurus.

Os animais eram de ambos os sexos, adultos e filhotes, sendo que, a maioria, apresentava estado nutricional bom e aparência sadia, exceto pela alta frequêencia de infestação pela forma larvária de Dermatobia hominis. Em alguns cães foram observadas outras alterações no tegumento, tais como, dermatite semelhante à sarna e sinais de briga.

Os animais reagentes encontravam-se dispersos por todo 0 assentamento, como pode ser observado na figura 11. 


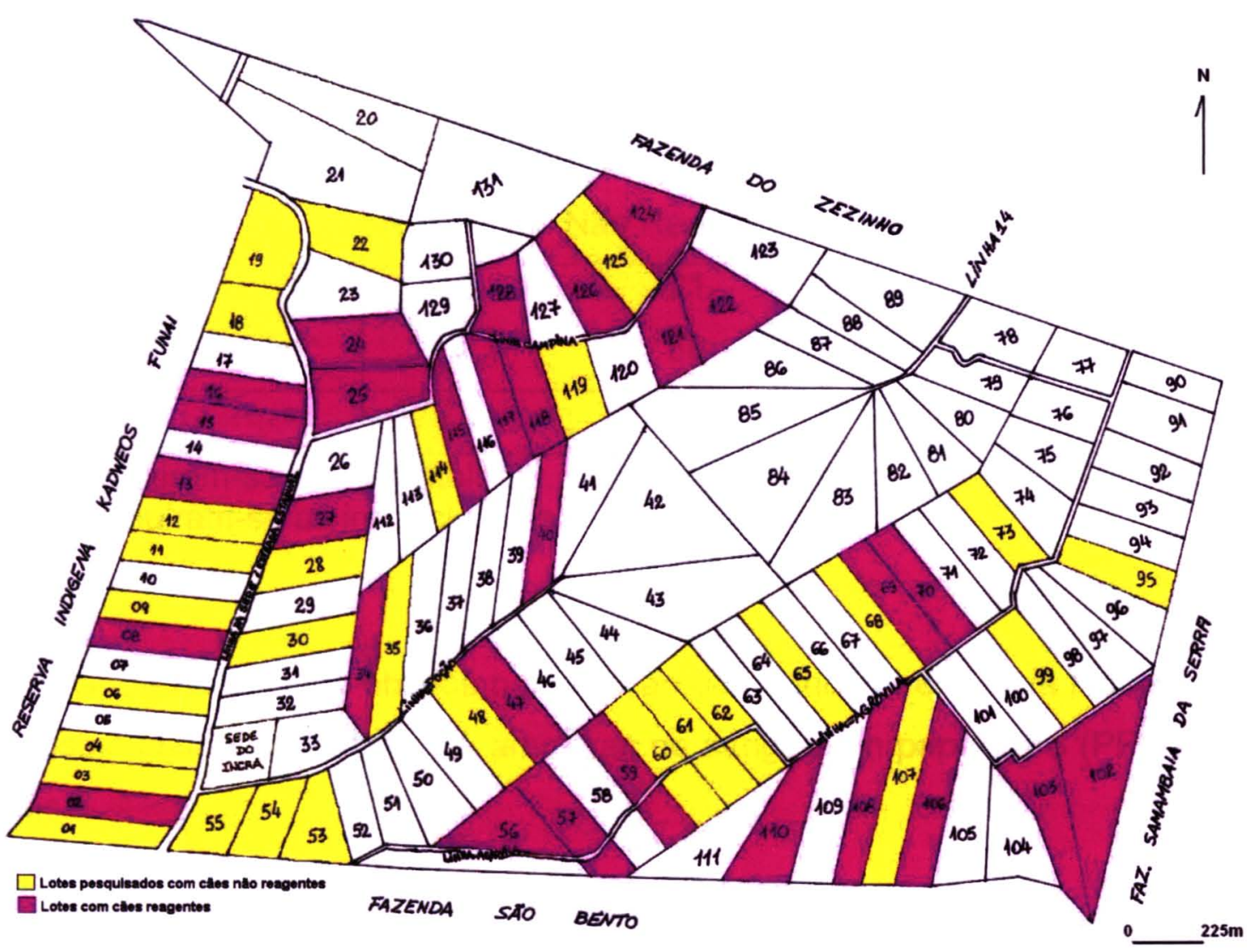

Figura 11 - Distribuição dos lotes onde foi pesquisada a presença de anticorpos anti-Leishmania em cães, por meio da RIFI, no Assentamento Guaicurus, Bonito - MS. Naqueles assinalados em amarelo, os cães foram não reagentes e em rosa, reagentes.

Os resultados obtidos no inquérito canino empregando-se a RIFI e o EIE estão dispostos nas tabelas de 1 e 2. 
Tabela 1 - Resultados obtidos pela reação de imunofluorescência indireta (RIFI) e o ensaio imunoenzimático (EIE) nas amostras de soro dos cães.

\begin{tabular}{l|cc|c}
\hline & \multicolumn{2}{|c|}{ RIFI soRo } & \\
EIE soro & Reagente & Não Reagente* & Total \\
\hline Reagente & 19 & 21 & 40 \\
Não Reagente & 1 & 88 & 89 \\
\hline Total & 20 & 109 & 129 \\
\hline * incluíram-se as com título 20. \\
** incluíram-se as inconclusivas.
\end{tabular}

Tabela 2 - Resultados obtidos pela reação de imunofluorescência indireta e o ensaio imunoenzimático nas amostras de sangue em papel filtro (PF) dos cães.

\begin{tabular}{|c|c|c|c|}
\hline \multirow[b]{2}{*}{ EIE $_{\mathrm{PF}}$} & \multicolumn{2}{|c|}{$\mathrm{RIFI}_{\mathrm{PF}}$} & \multirow[b]{2}{*}{ Total } \\
\hline & Reagente & Não Reagente & \\
\hline Reagente & 9 & 15 & 24 \\
\hline Não Reagente* & 2 & 103 & 105 \\
\hline Total & 11 & 118 & 129 \\
\hline
\end{tabular}

* incluíram-se as inconclusivas.

A reatividade observada com o emprego da reação de imunofluorescência indireta (RIFI) no soro foi de $15,5 \%(20 / 129)$, com títulos variando de 40 a 640 , e no sangue em papel filtro $8,5 \%(11 / 129)$.

A utilização do ensaio imunoenzimático (EIE) revelou para o soro $31,0 \%(40 / 129)$ e para o eluato sangüíneo $18,6 \%(24 / 129)$ de cães reagentes. 
Entre os 129 cães pesquisados $9(6,98 \%)$ foram reagentes, por meio das duas técnicas, tanto na amostra de soro como na amostra de eluato sanguineo.

Os resultados da reação de imunofluorescência indireta e ensaio imunoenzimático das amostras de soro e sangue em papel filtro, de cada cão examinado no Assentamento Guaicurus, encontram-se no anexo 2.

\subsubsection{Investigação dos cães reagentes e inconclusivos}

Entre os 44 cães com resultados reagentes ou tílulo 20 na RIFI ou EIE inconclusivo, no inquérito, foi possivel examinar e colher novas amostras de sangue de 28 animais e destes, colher aspirado medular de 24 cães.

As manifestações clínicas observadas nesses 28 cães foram variáveis. Alguns animais mostraram emagrecimento acentuado, crescimento exagerado de unhas (figuras 12 e 13), ulcerações, queda de pêlo (figura 14), secreções oculares, enquanto que, outros se apresentaram assintomáticos (figura 15). 


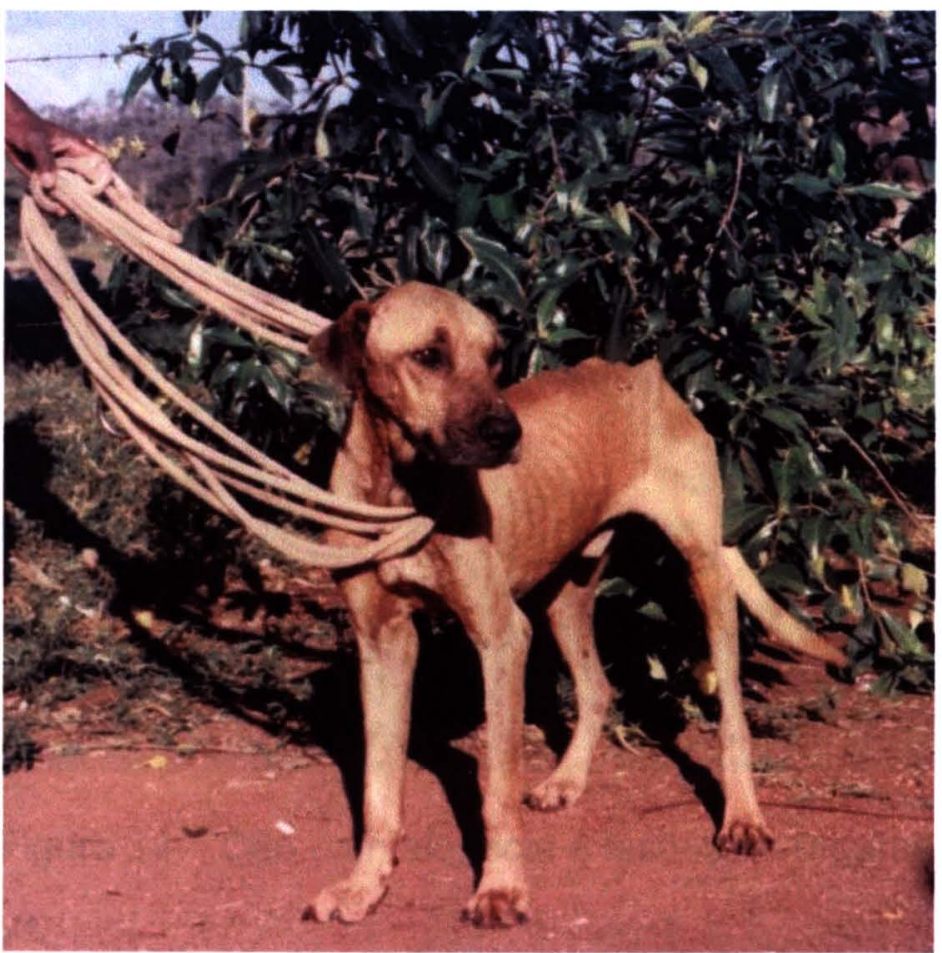

Figura 12 - Cão com emagrecimento e crescimento de unhas.

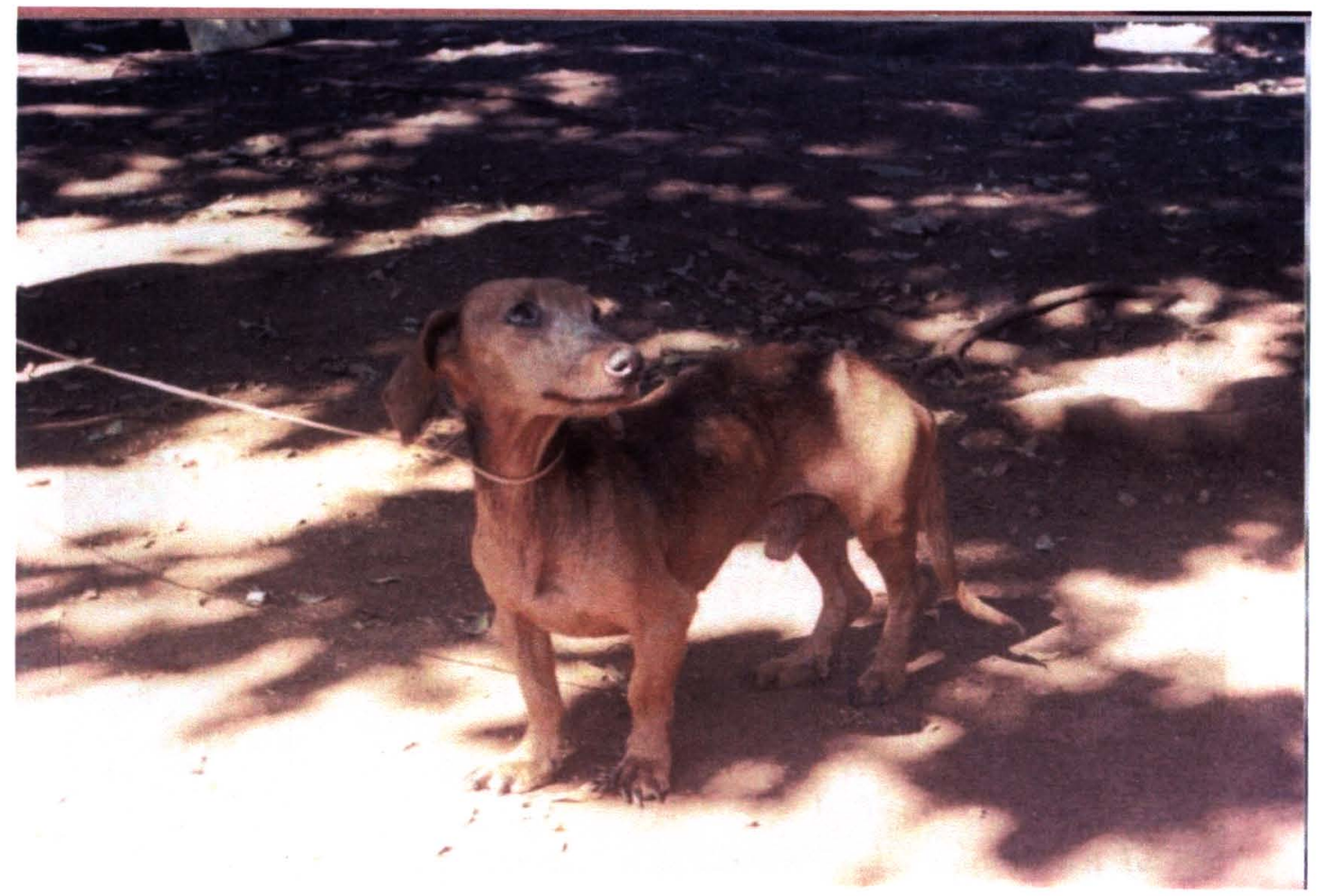

Figura 13 - Cão com emagrecimento acentuado e onicogrifose. 


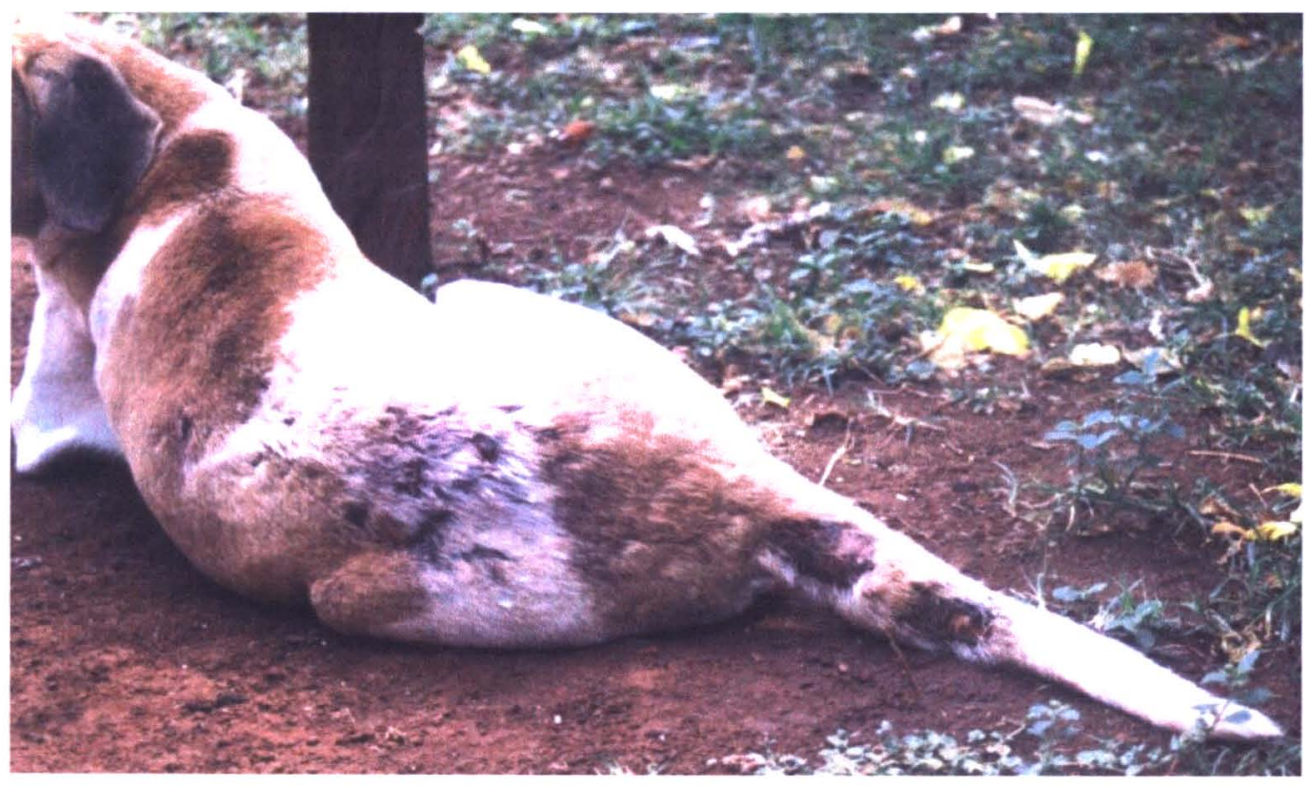

Figura 14 - Cão com alopecia e lesões no tegumento.

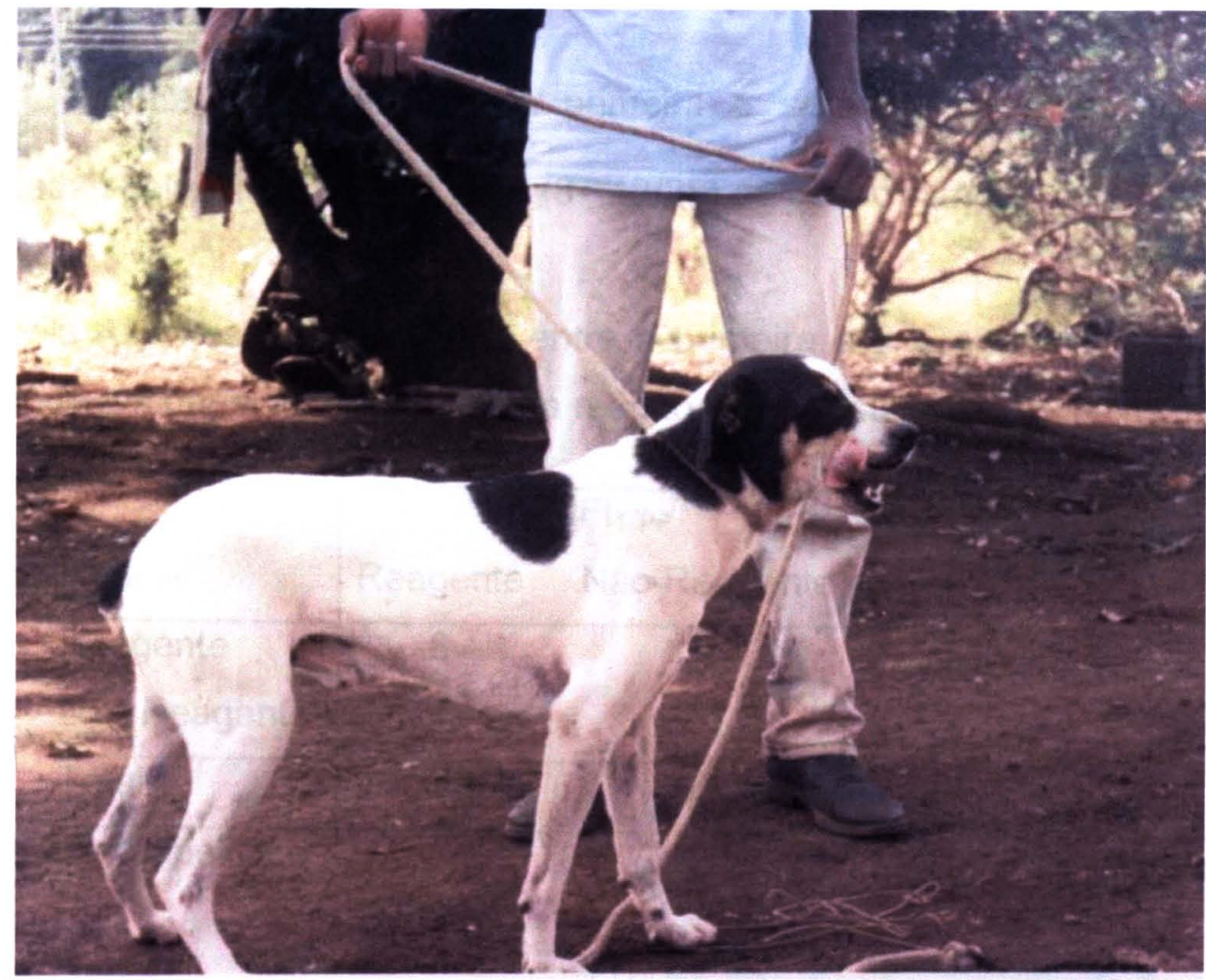

Figura 15 - Cão assintomático. 


\subsection{Segunda amostra de soro e eluato sanguineo}

As comparações entre os resultados obtidos na primeira e na segunda amostras de soro e sangue em papel filtro por meio de ambas as técnicas dos 28 cães analisados, podem ser observadas nas tabelas 3 a 6 .

Tabela 3 - Resultados obtidos pela reação de imunofluorescência indireta entre a primeira e segunda amostras de soro dos 28 cães pesquisados.

\begin{tabular}{|c|c|c|c|}
\hline \multirow[b]{2}{*}{$\mathrm{RIFI}_{2}$ SORO } & \multicolumn{2}{|c|}{$\mathrm{RIFI}_{1}$ SORO } & \multirow[b]{2}{*}{ Total } \\
\hline & Reagente & Não Reagente* & \\
\hline Reagente & 8 & 1 & 9 \\
\hline Não Reagente* & 7 & 12 & 19 \\
\hline Total & 15 & 13 & 28 \\
\hline
\end{tabular}

* incluíram-se as com título 20.

Entre os resultados da primeira e segunda amostras de soro, testadas pela RIFI, houve $71,4 \%(8+12 / 28)$ de concordância.

Tabela 4 - Resultados obtidos entre a primeira e a segunda amostras de sangue em papel filtro por meio da reação de imunofluorescência indireta.

\begin{tabular}{l|cc|c}
\hline & \multicolumn{2}{|c|}{$\mathrm{RIFI}_{1 \mathrm{PF}}$} & \\
$\mathrm{RIFI}_{2 \text { PF }}$ & Reagente & Não Reagente & Total \\
\hline Reagente & 6 & - & 6 \\
Não Reagente & 1 & 21 & 22 \\
\hline Total & 7 & 21 & 28 \\
\hline
\end{tabular}

$\overline{P F}=$ papel filtro 
Nas amostras de sangue em papel filtro, submetidas à RIFI, houve concordância de $96,4 \%(6+21 / 28)$ entre os resultados obtidos na primeira e segunda amostras.

Tabela 5 - Resultados obtidos pelo ensaio imunoenzimático entre a primeira e segunda amostras de soro dos 28 cães pesquisados.

\begin{tabular}{l|cc|c}
\hline & \multicolumn{2}{|c|}{ ElE $_{1 \text { SORO }}$} & \\
EIE $_{2 \text { soRo }}$ & Reagente & Não Reagente & Total \\
\hline Reagente & 20 & 3 & 23 \\
Não Reagente & 3 & 2 & 5 \\
\hline Total & 23 & 5 & 28 \\
\hline
\end{tabular}

* incluíram-se as inconclusivas.

Entre a primeira e segunda amostras de soro testadas pelo EIE, a concordância dos resultados foi de $78,6 \%(20+2 / 28)$.

Tabela 6 - Resultados obtidos entre a primeira e a segunda amostras de sangue em papel filtro por meio do ensaio imunoenzimático.

\begin{tabular}{l|cc|c}
\hline \multirow{2}{*}{$\mathrm{EIE}_{2 \mathrm{PF}}$} & \multicolumn{2}{|c|}{$\mathrm{EIE}_{1 \mathrm{PF}}$} & \\
\hline Reagente & Reagente & Não Reagente & Total \\
Não Reagente $^{*}$ & 14 & 8 & 22 \\
\hline Total & - & 6 & 6 \\
\hline
\end{tabular}

$\mathrm{PF}=$ papel filtro

* incluiram-se as inconclusivas.

A concordância entre os resultados da primeira e segunda amostras de sangue em papel filtro, testadas pelo EIE, foi de $71,4 \%(14+6 / 28)$. 
Os resultados, de cada cão pesquisado, da segunda amostra de soro e eluato sanguíneo, a sintomatologia, e o motivo pelo qual não foram colhidas amostras dos demais cães reagentes ou inconclusivos, encontramse no anexo 3.

\subsection{Ocorrência de co-infecção}

Nos esfregaços de aspirado de medula óssea corados pelo método de Giemsa, dos 24 cães foram encontradas formas amastigotas de Leishmania sp em somente um cão de nome Xebinha ( $\left.n^{\circ} 120\right)$, que também apresentava várias formas tripomastigotas, as quais, pela morfologia, foram identificadas como sendo de Trypanosoma evansi (figura 16). 

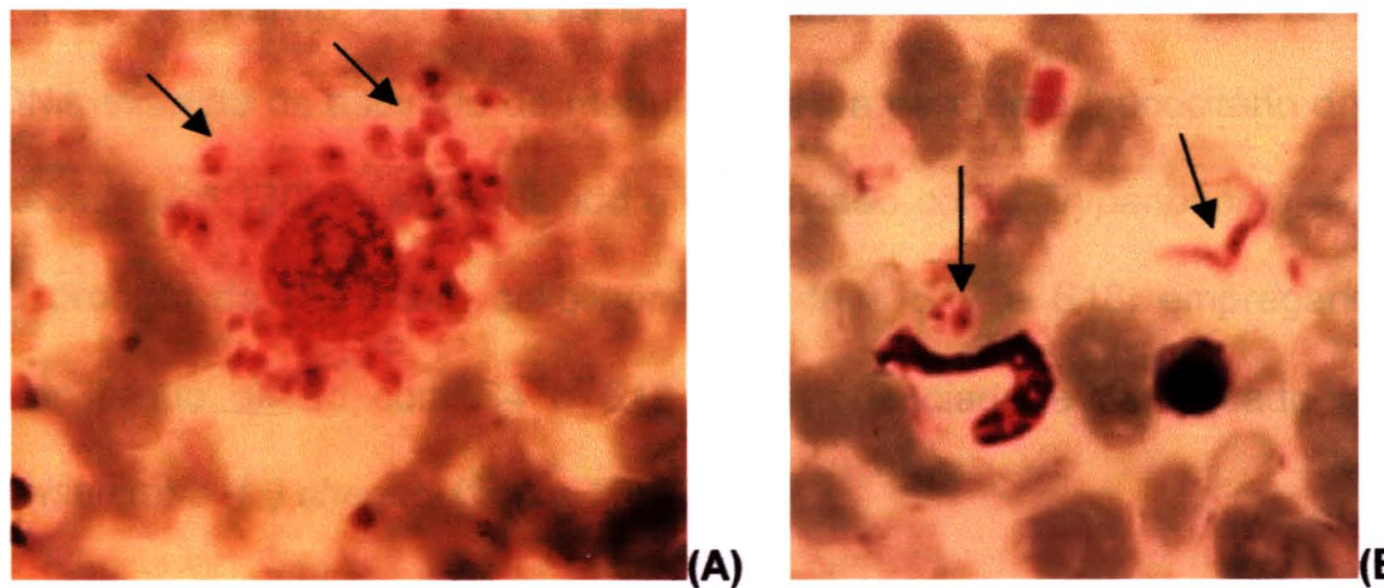

(B)

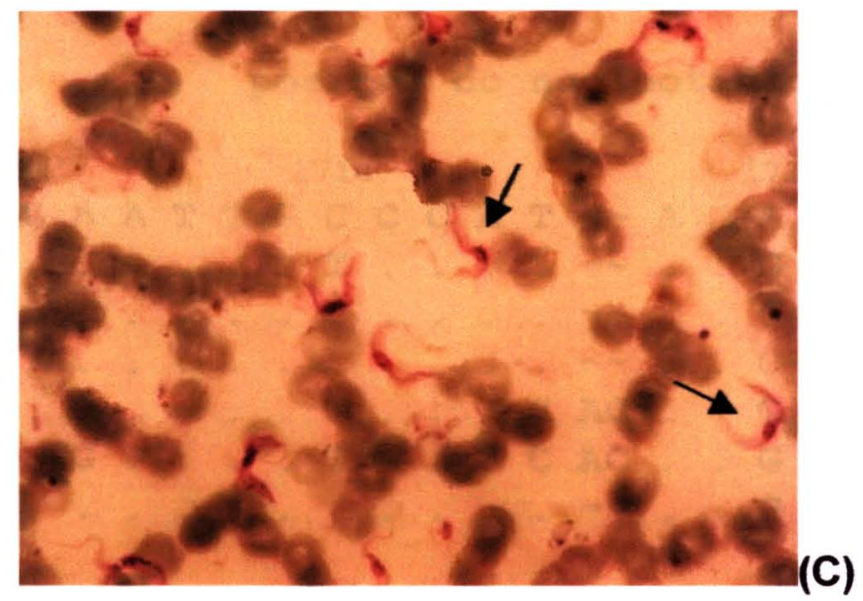

Figura 16 - Várias amastigotas de Leishmania encontradas no esfregaço de aspirado de medula óssea do cão Xebinha (A). Uma forma amastigota e uma tripomastigota no esfregaço de medula óssea (B). Diversas formas tripomastigotas de Trypanosoma evansi observadas em toda a extensão da lâmina desta amostra (C) (Fotos V. L. B. Nunes e I. M. N. Iha).

A primeira e segunda amostras de soro deste animal foram também testadas por meio da reação de imunofluorescência indireta frente ao antigeno de Trypanosoma cruzi e apresentaram títulos, 20 e 160, respectivamente, enquanto que frente ao antígeno de Leishmania (L.) chagasi, mostraram-se não reagente e reagente com titulo 40 , respectivamente. 
O produto da PCR com os oligonucleotideos $\mathrm{S} 4$ e S12, a partir de DNA extraído de aspirado de medula óssea e de creme leucocitário do căo Xebinha $\left(n^{\circ} 120\right)$ foi seqüenciado e identificado como Trypanosoma evansi. O produto da PCR com os oligonucleotídeos $\mathrm{S} 17$ e S18, empregando o amplificado obtido com S4 e S12, foi seqüenciado e identificado como Leishmania (L.) chagasi (figura 17).

Organismo

rDNA seqüência

posição do nucleotídeo

1708

1714

1721

1727

I.amazonensis G A A T T G C C C A T $\sim$ A G A A $T$ A G C A

I. (Viannia)

L. chagasi

T. cruzi

T. evansi

C AC

Cão Xebinha 1 . G . . . T . . C AC . . G . C . . .

Cão Xebinha 2

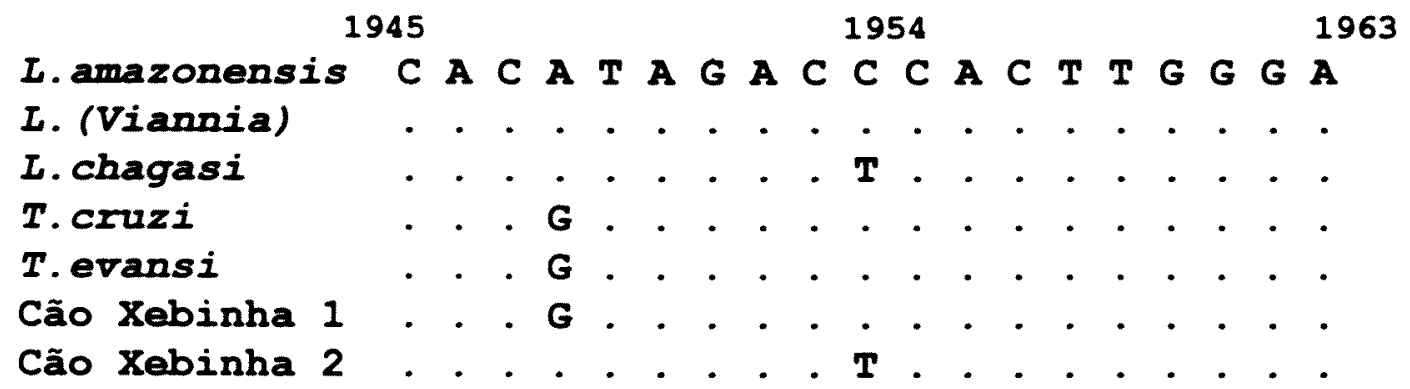

Figura 17 - Sequiências de nucleotídeos determinadas para o produto da PCR de DNA da amostra do cão Xebinha, alinhadas com as seqüências de cepas de referência do SSU rDNA, como descrito por ULIANA et al. (1994), permitindo a identificação dos parasitas deste animal. Produto da PCR com S4 e S12 (1) e "nested"-PCR com S17 e S18 (2) demonstrou infecção por Trypanosoma evansi e Leishmania (L.) chagasi, respectivamente. Os pontos representam bases idênticas a sequência de $L$. (L.) amazonensis e o til representa a posição de inserções na seqüência de $T$. evansi para alinhar as seqüências das espécies de Leishmania com as do Trypanosoma. 


\subsection{Análise parasitológica}

Entre os esfregaços de aspirado de medula óssea corados pelo Giemsa dos 24 cães pesquisados, somente foram encontradas formas amastigotas do parasita em um dos cães, como foi descrito no item anterior.

Em nenhuma das 24 amostras de aspirado de medula, semeadas em meio de cultura Blood Agar Base, foi possivel demonstrar a presença de formas promastigotas do protozoário.

Das 24 amostras de aspirado de medula inoculadas, foi possivel isolar promastigotas de Leishmania a partir de baço e fígado dos hamsters de dez cães, porém como os hamsters perderam a marcação, não foi possível saber quais eram. Essas culturas foram encaminhadas ao Instituto Evandro Chagas, porém somente uma pôde ser identificada por imunofluorescência com anticorpos monoclonais (SHAW et al. 1989), sendo que a espécie encontrada foi $L$. (L.) chagasi.

\subsection{Análise molecular}

Os resultados obtidos na reação em cadeia da polimerase (PCR) a partir das amostras de DNA extraidas de creme leucocitário e aspirado de medula óssea dos cães, encontram-se na tabela 7 e figuras 18 e 19. 
Tabela 7: Resultados das PCR com os pares de oligonucleotídeos S4/S12 e S17/S18, utilizando amostras de DNA extraídas de creme leucocitário e aspirado de medula óssea de cães do Assentamento Guaicurus, município de Bonito, MS.

\begin{tabular}{lcccccccc}
\hline & \multicolumn{3}{c}{ Aspirado de medula óssea } & \multicolumn{3}{c}{ Creme leucocitário } \\
& \multicolumn{2}{c}{ S4 e S12 } & \multicolumn{2}{c}{ S17 e S18* } & \multicolumn{2}{c}{ S4 e S12 } & \multicolumn{2}{c}{ S17 e S18* } \\
Resultados & $\mathrm{N}$ & $\%$ & $\mathrm{~N}$ & $\%$ & $\mathrm{~N}$ & $\%$ & $\mathrm{~N}$ & $\%$ \\
\hline Positivos & 6 & 25,0 & 20 & 83,3 & 24 & 85,7 & 27 & 96,4 \\
Negativos & 18 & 75,0 & 4 & 16,7 & 4 & 14,3 & $1^{* *}$ & 3,6 \\
\hline Total & 24 & 100,0 & 24 & 100,0 & 28 & 100,0 & 28 & 100,0 \\
\hline
\end{tabular}

*Essa reação foi executada empregando-se o produto da PCR com S4/S12, como descrito anteriormente.

** Deste animal não foi colhido aspirado de medula óssea (anexo 4).

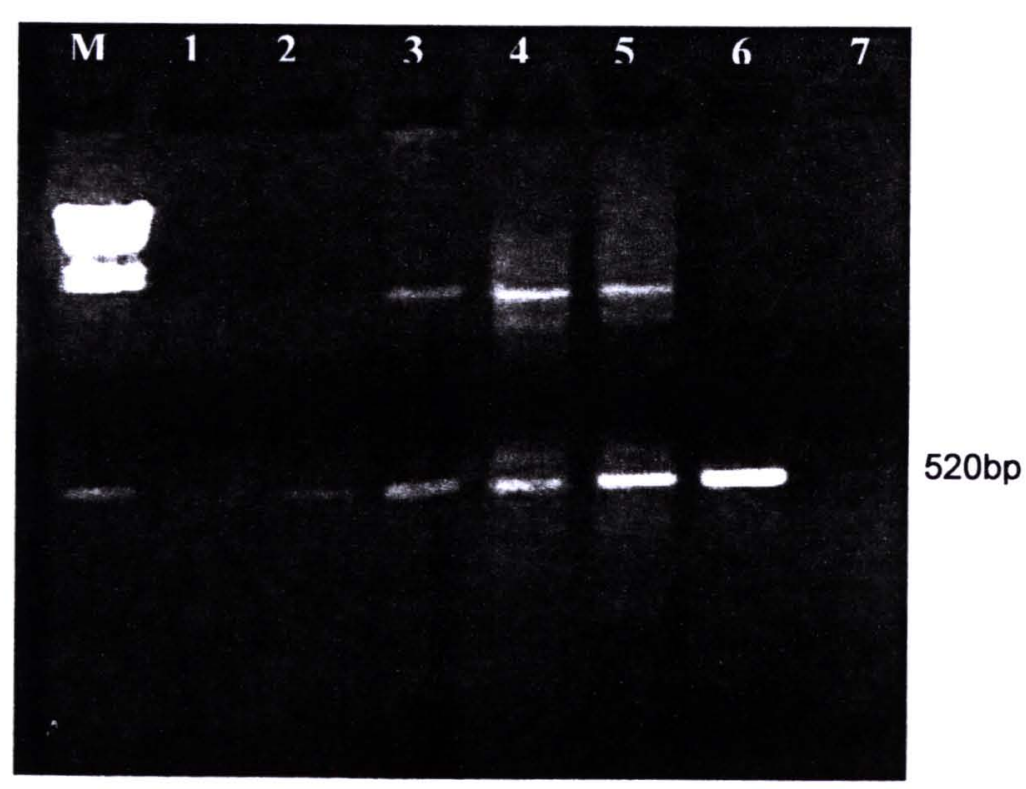

Figura 18 - Eletroforese em gel de agarose $2 \%$ do produto da PCR obtido com os oligonucleotídeos S4 e S12. M = marcador molecular lambda/Hind III; canaletas de 1 a 5 = DNA de amostras de creme leucocitário ou aspirado de medula óssea dos cães; 6 = DNA de promastigotas de Leishmania (L.) amazonensis (controle positivo); 7 = controle negativo sem DNA. 


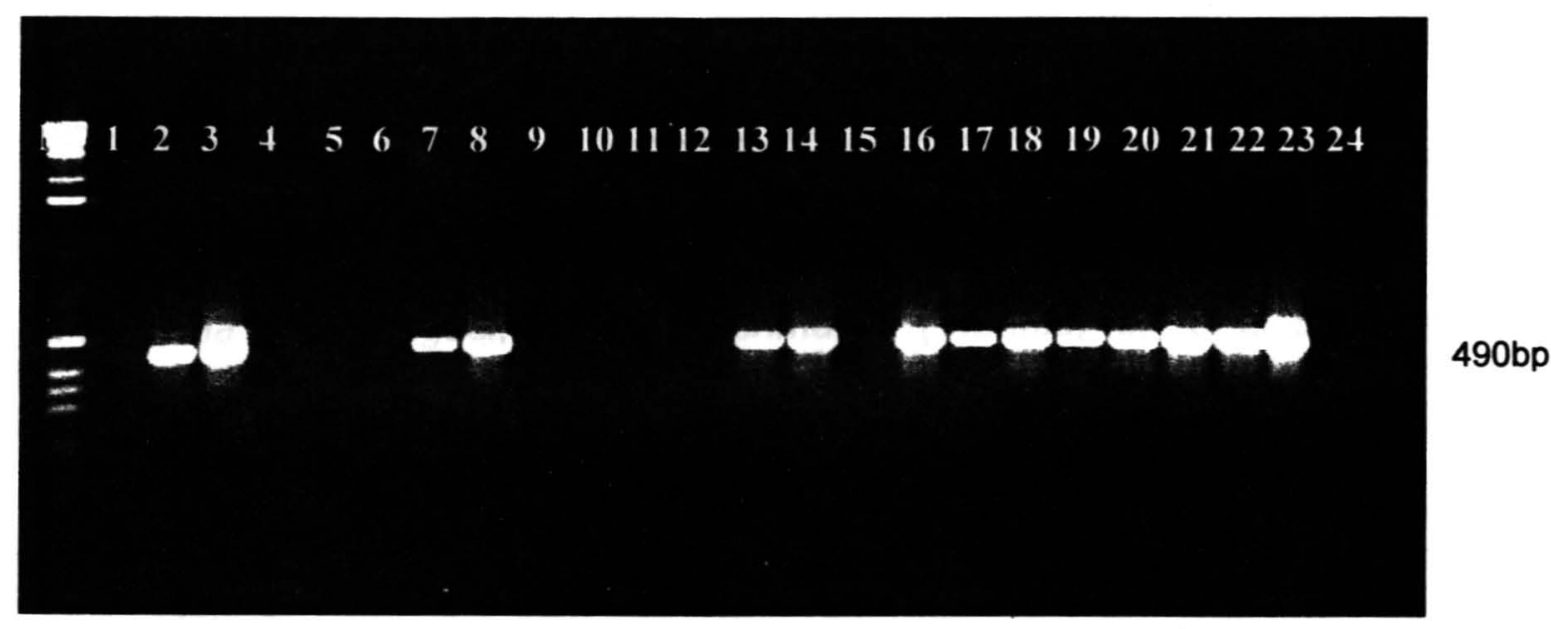

Figura 19 - Eletroforese em gel de agarose $2 \%$ do produto da PCR obtido com os oligonucleotídeos $\mathbf{S 1 7}$ e $\mathbf{S 1 8}$. $\mathrm{M}=$ marcador molecular $1 \mathrm{~kb}$ DNA; canaletas de 1 a 22 = DNA de amostras de creme leucocitário ou aspirado de medula óssea dos cães; 23 = DNA de promastigotas de Leishmania (L.) amazonensis (controle positivo); 24 = controle negativo sem DNA.

Na figura 18, ilustrativa dos resultados apresentados na tabela 7 , percebe-se que as bandas de cerca de $520 \mathrm{bp}$, resultantes da PCR com os oligonucleotídeos $\mathrm{S} 4 / \mathrm{S} 12$, apresentaram-se ou muito fracas, por vezes, até de difícil visualização (canaleta 1); fracas (canaletas 2 e 3); ou fortes, porém com bandas inespecificas (canaletas 4 e 5). $O$ produto da PCR com os oligonucleotídeos S17/S18 (figura 19), mostraram bandas de cerca de $490 \mathrm{bp}$ fortes e sem a presença de bandas inespecíficas (canaletas 2; 3; 7; $8 ; 13 ; 14 ; 16$ a 22$)$.

A positividade para DNA de Leishmania nas amostras caninas de creme leucocitário foi de $96,4 \%$, enquanto que nas de aspirado de medula óssea foi de $83,3 \%$. Os quatro cães que se apresentaram negativos na PCR com DNA extraído de aspirado de medula óssea, foram positivos com o creme leucocitário. 
Entre os 28 cães pesquisados, foram detectados por meio da PCR com S17/S18, 27 animais infectados por Leishmania. O seqüenciamento com S18 do produto dessa PCR, demonstrou 19 cães infectados por Leishmania (L.) chagasi, 6 por Leishmania (Viannia) sp e 2 cães por Leishmania (L.) amazonensis (figura 20).

Organismo

rDNA sequiência

posição do nucleotídeo

$1708 \quad 1714 \quad 1721$

1727

L.amazonensis G A A T T G C C C A T A G A A T A G C A

I. (Viannia)

L. chagasi

Cão Camoio

Cão Trovão

Cão Pitoco

\section{5}

1954

1963

L.amazonensis C A C A T A G A C C C A C T T G G G A

L. (Viannia)

L. Chagasi

Cão Camoio

Cão Trovão

Cão Pitoco

Figura 20 - Seqüências de nucleotídeos determinadas para o produto da "nested"-PCR de DNA das amostras alinhadas com as seqüências de cepas de referência do SSU rDNA, conforme descrito por ULIANA et al. (1994), permitindo a identificação da espécie de Leishmania. Cão Pitoco está infectado por $L$. (L.) chagasi, cão Trovão por $L$. (L.) amazonensis e cão Camoio por $L$. (Viannia) sp. Os pontos representam bases idênticas a sequência de $L$. (L.) amazonensis.

Os resultados das reações em cadeia da polimerase para cada animal, encontram-se no anexo 4. 


\subsection{Sintomatologia e reatividade dos cães infectados}

A análise do quadro clinico, ou seja, a presença ou ausência de sintomas característicos de leishmaniose, e da reatividade sorológica dos 27 cães infectados por Leishmania, detectados pela PCR, pode ser observada nas tabelas 8 a 10.

Tabela 8 - Distribuição dos 27 cães com PCR (S17/S18) positiva para Leishmania e destes, os reagentes pela RIFI ou EIE na segunda amostra de soro, segundo os sinais clínicos.

\begin{tabular}{l|cccccc}
\hline \multirow{2}{*}{ Sintomas } & \multicolumn{2}{|c}{ PCR } & \multicolumn{2}{c}{ EIE } & \multicolumn{2}{c}{ RIFI } \\
& No $^{\circ}$ & $\%$ & No $^{\circ}$ & $\%$ & No $^{\circ}$ & $\%$ \\
\hline Sintomático & 17 & 63,0 & 15 & 68,2 & 8 & 88,9 \\
Assintomático & 10 & 37,0 & 7 & 31,8 & 1 & 11,1 \\
\hline Total & 27 & 100,0 & 22 & 100,0 & 9 & 100,0 \\
\hline
\end{tabular}

Entre os 27 cães infectados por Leishmania, detectados pela PCR com os oligonucleotideos S17 e S18, observou-se que $37 \%$ (10) eram assintomáticos e $63 \%$ sintomáticos (tabela 8), destes, $41 \%$ eram oligossintomáticos (11 animais com um ou dois sintomas) e $22 \%$ polissintomáticos (6 cães com três ou mais sintomas). Os sintomas observados foram perda de peso, onicogrifose, conjuntivite, alopecia, dermatites e úlceras de pele.

Entre os cães infectados que foram reagentes pela RIFI, $88,9 \%$ apresentavam sintomas e $11,1 \%$ eram assintomáticos, enquanto que 
daqueles que foram reagentes pelo EIE, $68,2 \%$ eram sintomáticos e $31,8 \%$ não apresentavam sintomas (tabela 8).

Tabela 9 - Distribuição dos cães reagentes na segunda amostra de soro pela RIFI ou EIE, segundo os sinais clínicos sugestivos de leishmanioses, dentre os 27 cães infectados por Leishmania detectados pela PCR (S17/S18).

\begin{tabular}{l|ccccc}
\hline Sintomas & PCR & \multicolumn{2}{c}{ EIE } & \multicolumn{2}{c}{ RIFI } \\
& No $^{\circ}$ & No $^{\circ}$ & $\%$ & No $^{\circ}$ & $\%$ \\
\hline Sintomático & 17 & 15 & $88,2(15 / 17)$ & 8 & $47,1(8 / 17)$ \\
Assintomático & 10 & 7 & $70,0(7 / 10)$ & 1 & $10,0(1 / 10)$ \\
\hline Total & 27 & 22 & $81,5(22 / 27)$ & 9 & $33,3(9 / 27)$ \\
\hline
\end{tabular}

Entre os cães infectados por protozoários do gênero Leishmania (27 animais) foi possivel detectar anticorpos na segunda amostra de soro de $81,5 \%$ destes animais pelo EIE e de $33,3 \%$ pela RIFI. O EIE detectou $88,2 \%$ dos animais sintomáticos e $70,0 \%$ dos assintomáticos, enquanto a RIFI detectou $47,1 \%$ e $10,0 \%$, respectivamente (tabela 9 ).

Tabela 10 - Distribuição dos cães reagentes na primeira amostra de soro pela RIFI ou EIE, segundo os sinais clínicos sugestivos de leishmanioses, dentre os 27 cães infectados por Leishmania detectados pela PCR (S17/S18).

\begin{tabular}{l|ccccc}
\hline \multirow{2}{*}{ Sintomas } & PCR & \multicolumn{2}{|c}{ EIE } & \multicolumn{2}{c}{ RIFI } \\
\hline Sintomático & 17 & 17 & $100,0(17 / 17)$ & 10 & $58,8(10 / 17)$ \\
Assintomático & 10 & 7 & $70,0(7 / 10)$ & 5 & $50,0(5 / 10)$ \\
\hline Total & 27 & 24 & $88,9(24 / 27)$ & 15 & $55,6(15 / 27)$ \\
\hline
\end{tabular}


$\mathrm{Na}$ primeira amostra de soro desses animais infectados, o EIE detectou $88,9 \%$ enquanto a RIFI $55,6 \%$. O EIE detectou todos os animais sintomáticos e $70,0 \%$ dos assintomáticos, a RIFI demonstrou presença de anticorpos em $58,8 \%$ dos sintomáticos e em $50,0 \%$ dos cães sem sintomas da doença (tabela 10).

O único cão que foi negativo nas PCR's, com DNA extraído a partir de creme leucocitário, não apresentava sintomas da doença. A segunda amostra de soro e de eluato sanguíneo desse animal foram não reagentes pela RIFI e pelo EIE, somente a primeira amostra de soro pelo EIE foi inconclusiva.

\subsection{Inquérito sobre a fauna flebotominea}

\subsubsection{Fauna encontrada}

A fauna flebotomínea capturada no Assentamento Guaicurus compreendeu 4 subtribos, 9 gêneros e 15 espécies:

BRUMPTOMYIINA: Brumptomyia avellari (Costa Lima, 1932), Brumptomyia brumpti (Larrousse, 1920), Brumptomyia cunhai (Mangabeira, 1942).

LUTZOMYIINA: Evandromyia (Barrettomyia) corumbaensis (Galati, Nunes, Oshiro \& Rego, 1989), Lutzomyia (Lutzomyia) almerioi Galati \& Nunes, 1999, Lutzomyia (Lutzomyia) longipalpis (Lutz \& Neiva, 1912), Lutzomyia dispar Martins \& Silva, 1963, Pintomyia (Pintomyia) kuscheli (Le 
Pont, Martinez, Torrez-Espejo \& Dujardin, 1998), Sciopemyia sordellii (Shannon \& Del Ponte, 1927);

PSYCHODOPYGINA: Martinsmyia oliveirai (Martins, Silva \& Falcão, 1970), Nyssomyia whitmani (Antunes \& Coutinho, 1939), Psathyromyia (Psathyromyia) punctigeniculata (Floch \& Abonnenc, 1944), Psathyromyia (Psathyromyia) shannoni (Dyar, 1929) e

SERGENTOMYIINA: Micropygomyia (Sauromyia) peresi (Mangabeira, 1942), Micropygomyia quinquefer (Dyar, 1929).

\subsubsection{Comportamento da fauna}

\subsubsection{Densidade}

O total de flebotomíneos capturados em armadilhas automáticas luminosas com e sem inseticida e de Shannon no Assentamento Guaicurus, no periodo de outubro de 2002 a outubro de 2003, segundo sexo, espécie e lote de captura e por ambiente, pode ser visto nas tabelas 11 e 12 . 
Tabela 11 - Flebotomíneos capturados em armadilhas de Shannon e CDC com e sem inseticida no Assentamento Guaicurus, outubro de 2002 a outubro de 2003 , segundo sexo, espécie e lote de captura.

\begin{tabular}{|c|c|c|c|c|c|c|c|c|c|c|c|c|c|c|c|c|c|c|c|c|c|c|c|c|c|c|c|c|}
\hline \multirow{3}{*}{ Espécie } & \multicolumn{28}{|c|}{ LOTE } \\
\hline & \multicolumn{4}{|c|}{2} & \multicolumn{4}{|c|}{19} & \multicolumn{4}{|c|}{20} & \multicolumn{4}{|c|}{35} & \multicolumn{4}{|c|}{59} & \multicolumn{4}{|c|}{102} & \multicolumn{4}{|c|}{110} \\
\hline & $F$ & $M$ & $T$ & $\%$ & F & $M$ & I & $\%$ & $\mathbf{F}$ & $M$ & $T$ & $\%$ & $F$ & $M$ & $T$ & $\%$ & $F$ & $M$ & $T$ & $\%$ & $F$ & $M$ & $T$ & $\%$ & $F$ & $M$ & $T$ & $\%$ \\
\hline Brumptomyia avellari & 2 & 3 & 5 & 0,03 & 2 & 3 & 5 & 0,03 & 0 & 0 & 0 & 0,00 & 0 & 0 & 0 & 0,00 & 0 & 0 & 0 & 0,00 & 0 & 0 & 0 & 0,00 & 0 & 0 & 0 & 0,00 \\
\hline Brumptomyia brumpti & 3 & 4 & 7 & 0,04 & 1 & 3 & 4 & 0,02 & 3 & 2 & 5 & 0,03 & 0 & 0 & 0 & 0,00 & 0 & 0 & 0 & 0,00 & 0 & 0 & 0 & 0,00 & 0 & 0 & 0 & 0,00 \\
\hline Brumptomyia cunhai & 29 & 46 & 75 & 0,38 & 20 & 9 & 29 & 0,15 & 14 & 24 & 38 & 0,19 & 3 & 3 & 6 & 0,03 & 0 & 0 & 0 & 0,00 & 0 & 4 & 4 & 0,02 & 13 & 8 & 21 & 0,11 \\
\hline Brumptomyia sp * & 1 & 0 & 1 & 0,01 & 4 & 0 & 4 & 0,02 & 4 & 0 & 4 & 0,02 & 0 & 0 & 0 & 0,00 & 0 & 0 & 0 & 0,00 & 0 & 0 & 0 & 0,00 & 0 & 0 & 0 & 0,00 \\
\hline Evandromyia corumbaensis & 20 & 0 & 20 & 0,10 & 19 & 0 & 19 & 0,10 & 36 & 3 & 39 & 0,20 & 0 & 0 & 0 & 0,00 & 7 & 1 & 8 & 0,04 & 5 & 1 & 6 & 0,03 & 0 & 0 & 0 & 0,00 \\
\hline Lutzomyia almerioi & 5 & 4 & 9 & 0,05 & 700 & 181 & 881 & 4,51 & 919 & 834 & 1753 & 8,97 & 0 & 1 & 1 & 0,01 & 6 & 6 & 12 & 0,06 & 0 & 2 & 2 & 0,01 & 4 & 4 & 8 & 0,04 \\
\hline Lutzomyia dispar & 0 & 0 & 0 & 0,00 & 0 & 0 & 0 & 0,00 & 1 & 0 & 1 & 0,01 & 0 & 0 & 0 & 0,00 & 0 & 0 & 0 & 0,00 & 0 & 0 & 0 & 0,00 & 0 & 0 & 0 & 0,00 \\
\hline Lutzomyia longipalpis & 47 & 106 & 153 & 0,78 & 3691 & 6118 & 9809 & 50,20 & 711 & 2592 & 3303 & 16,91 & 1 & 8 & 9 & 0,05 & 8 & 23 & 31 & 0,16 & 5 & 8 & 13 & 0,07 & 30 & 80 & 110 & 0,56 \\
\hline Martinsmyia oliveirai & 0 & 0 & 0 & 0,00 & 5 & 0 & 5 & 0,03 & 13 & 2 & 15 & 0,08 & 0 & 0 & 0 & 0,00 & 0 & 0 & 0 & 0,00 & 0 & 0 & 0 & 0,00 & 0 & 0 & 0 & 0,00 \\
\hline Micropygomyia peresi & 0 & 0 & 0 & 0,00 & 2 & 0 & 2 & 0,01 & 19 & 6 & 25 & 0,13 & 0 & 0 & 0 & $0 . n 0$ & 0 & 0 & 0 & 0,00 & 1 & 0 & 1 & 0,01 & 0 & 0 & 0 & 0,00 \\
\hline Micropygomyia quinquefer & 0 & 0 & 0 & 0,00 & 3 & 1 & 4 & 0,02 & 18 & 8 & 26 & 0,13 & 0 & 0 & 0 & 0,00 & 0 & 0 & 0 & 0,00 & 0 & 2 & 2 & 0,01 & 0 & 0 & 0 & 0,00 \\
\hline Nyssomyia whitmani & 6 & 4 & 10 & 0,05 & 104 & 282 & 386 & 1,98 & 41 & 87 & 128 & 0,66 & 0 & 0 & 0 & 0,00 & 1 & 1 & 2 & 0,01 & 1 & 1 & 2 & 0,01 & 1 & 0 & 1 & 0,01 \\
\hline Pintomyia (P.) kuscheli & 0 & 0 & 0 & 0,00 & 1 & 0 & 1 & 0,01 & 13 & 0 & 13 & 0,07 & 0 & 0 & 0 & 0,00 & 1 & 0 & 1 & 0,01 & 0 & 0 & 0 & 0,00 & 2 & 0 & 2 & 0,01 \\
\hline Psathyromyla punctigeniculata & 0 & 0 & 0 & 0,00 & 1 & 0 & 1 & 0,01 & 8 & 4 & 12 & 0,06 & 0 & 0 & 0 & 0,00 & 1 & 0 & 1 & 0,01 & 0 & 0 & 0 & 0,00 & 0 & 1 & 1 & 0,01 \\
\hline Psathyromyia shannoni & 0 & 6 & 6 & 0,03 & 16 & 228 & 244 & 1,25 & 1 & 81 & 82 & 0,42 & 0 & 0 & 0 & 0,00 & 0 & 0 & 0 & 0,00 & 0 & 0 & 0 & 0,00 & 0 & 0 & 0 & 0,00 \\
\hline Sciopemyia sordellii & 2 & 1 & 3 & 0,02 & 8 & 8 & 16 & 0,08 & 13 & 7 & 20 & 0,10 & 0 & 0 & 0 & 0,00 & 0 & 0 & 0 & 0,00 & 0 & 0 & 0 & 0,00 & 0 & 2 & $\underline{2}$ & 0,01 \\
\hline TOTAL & 115 & 174 & 289 & 1,48 & 4577 & 6833 & 11410 & 58,40 & 1814 & 3650 & 5464 & 27,97 & 4 & 12 & 16 & 0,08 & 24 & 31 & 55 & 0,28 & 12 & 18 & 30 & 0,15 & 50 & 95 & 145 & \\
\hline
\end{tabular}

$F=$ fêmea

$M=$ macho

* provavelmente represente fêmea de uma das espécies de Brumptomyia encontradas no Assentamento Guaicurus

continua 
continuação

\begin{tabular}{|c|c|c|c|c|c|c|c|c|c|c|c|c|c|c|c|c|c|c|c|c|c|c|c|c|c|c|c|c|c|c|}
\hline \multirow[t]{2}{*}{ Espécie } & \multicolumn{26}{|c|}{ LOTE } & \multicolumn{4}{|c|}{ TOTAL } \\
\hline & $F$ & $M$ & $T$ & $\%$ & $F$ & M & $T$ & $\%$ & $F$ & $M$ & $T$ & $\%$ & $F$ & $M$ & $T$ & $\%$ & $F$ & $M T$ & $\%$ & $F$ & $M$ & T 0 & $\%$ & $F M$ & $M T$ & $\%$ & $F$ & $M$ & $T$ & $\%$ \\
\hline B. avellari & 0 & 0 & 0 & 0,00 & 0 & 0 & 0 & 0,00 & 0 & 0 & 0 & 0,00 & 0 & 0 & 0 & 0,00 & 0 & 00 & 0,00 & 0 & 0 & $0 \quad 0$, & 0,00 & 00 & 00 & 0,00 & 4 & 6 & 10 & 0,05 \\
\hline B. brumpti & 0 & 0 & 0 & 0,00 & 0 & 0 & 0 & 0,00 & 1 & 0 & 1 & 0,01 & 0 & 0 & 0 & 0,00 & 0 & 00 & 0,00 & 0 & 0 & $\begin{array}{ll}0 & 0,\end{array}$ & 0,00 & 00 & 00 & 0,00 & 8 & 9 & 17 & 0,09 \\
\hline B.cunhai & 2 & 2 & 4 & 0,02 & 0 & 1 & 1 & 0,01 & 4 & 1 & 5 & 0,03 & 7 & 16 & 23 & 0,12 & 0 & 00 & 0,00 & 0 & 1 & 10 , & 0,01 & 00 & 00 & 0,00 & 92 & 115 & 207 & 1,06 \\
\hline Brumptomyia sp * & 0 & 0 & 0 & 0,00 & 0 & 0 & 0 & 0,00 & 0 & 0 & 0 & 0,00 & 0 & 0 & 0 & 0,00 & 0 & 00 & 0,00 & 0 & 0 & 00 & 0,00 & 00 & 00 & 0,00 & 9 & 0 & 9 & 0,05 \\
\hline E. corumbaensis & 0 & 0 & 0 & 0,00 & 0 & 0 & 0 & 0,00 & 10 & 1 & 11 & 0,06 & 5 & 3 & 8 & 0,04 & 0 & 00 & 0,00 & 0 & 0 & $\begin{array}{ll}0 & 0,\end{array}$ & 0,00 & 10 & $0 \quad 1$ & 0,01 & 103 & 9 & 112 & 0,57 \\
\hline L. almerioi & 25 & 3 & 28 & 0,14 & 9 & 10 & 19 & 0,10 & 10 & 13 & 23 & 0,12 & 8893 & 303 & 1192 & 6,10 & 12 & $0 \quad 12$ & 20,06 & 0 & 0 & $\begin{array}{ll}0 & 0,\end{array}$ & 0,00 & 20 & 02 & 0,01 & 2581 & 1361 & 3942 & 20,18 \\
\hline L. dispar & 0 & 0 & 0 & 0,00 & 0 & 0 & 0 & 0,00 & 0 & 0 & 0 & 0,00 & 0 & 0 & 0 & 0,00 & 0 & 00 & 0,00 & 0 & 0 & 00, & 0,00 & 00 & $\begin{array}{ll}0 & 0\end{array}$ & 0,00 & 1 & 0 & 1 & 0,01 \\
\hline L. longipalpis & 32 & 25 & 57 & 0,29 & 38 & 40 & 78 & 0,40 & 168 & 373 & 541 & 2,77 & 5 & 20 & 25 & 0,13 & 2 & 46 & 0,03 & 0 & 0 & 00 & 0,00 & 14 & 45 & 0,03 & 4739 & 9401 & 14140 & 72,37 \\
\hline M. oliveirai & 0 & 0 & 0 & 0,00 & 0 & 0 & 0 & 0,00 & 0 & 0 & 0 & 0,00 & 26 & 19 & 45 & 0,23 & 0 & $\begin{array}{ll}0 & 0\end{array}$ & 0,00 & 0 & 0 & 00 &, 00 & $\begin{array}{ll}0 & 0\end{array}$ & 0 & 0,00 & 44 & 21 & 65 & 0,33 \\
\hline M. peresi & 0 & 0 & 0 & 0,00 & 0 & 0 & 0 & 0,00 & 0 & 0 & 0 & 0,00 & 0 & 0 & 0 & 0,00 & 0 & 00 & 0,00 & 0 & 0 & 00 & 000 & $\begin{array}{ll}0 & 0\end{array}$ & $\begin{array}{ll}0 & 0\end{array}$ & 0,00 & 22 & 6 & 28 & 0,14 \\
\hline M. quinquefer & 0 & 0 & 0 & 0,00 & 0 & 0 & 0 & 0,00 & 0 & 0 & 0 & 0,00 & 0 & 1 & 1 & 0,01 & 0 & 00 & 0,00 & 0 & 0 & $0 \quad 0$ & 0,00 & 00 & 00 & 0,00 & 21 & 12 & 33 & 0,17 \\
\hline N. whitmani & 0 & 0 & 0 & 0,00 & 0 & 0 & 0 & 0,00 & 4 & 17 & 21 & 0,11 & 0 & 0 & 0 & 0,00 & 0 & $\begin{array}{ll}0 & 0\end{array}$ & 0,00 & 2 & 0 & 20 & 0,01 & 00 & 0 & 0,00 & 160 & 392 & 552 & 2,83 \\
\hline P.(P.) kuscheli & 0 & 0 & 0 & 0,00 & 0 & 0 & 0 & 0,00 & 1 & 0 & 1 & 0,01 & 0 & 0 & 0 & 0,00 & 0 & 00 & 0,00 & 0 & 0 & 00 & 0,00 & 00 & 0 & 0,00 & 18 & 0 & 18 & 0,09 \\
\hline P. punctigeniculata & 0 & 0 & 0 & 0,00 & 0 & 0 & 0 & 0,00 & 0 & 0 & 0 & 0,00 & 2 & 0 & 2 & 0,01 & 0 & 00 & 0,00 & 0 & 0 & $\begin{array}{ll}0 & 0\end{array}$ & 0,00 & 10 & 1 & 0,01 & 13 & 5 & 18 & 0,09 \\
\hline P. shannoni & 0 & 0 & 0 & 0,00 & 0 & 0 & 0 & 0,00 & 0 & 4 & 4 & 0,02 & 0 & 0 & 0 & 0,00 & 0 & 00 & 0,00 & 0 & 0 & 00 & 0,00 & 00 & 0 & 0,00 & 17 & 319 & 336 & 1,72 \\
\hline S. sordellii & 0 & 0 & 0 & 0,00 & 0 & 0 & 0 & 0,00 & 4 & 2 & 6 & 0,03 & 1 & 1 & 2 & 0,01 & 0 & $0 \quad 0$ & 0,00 & 1 & 0 & 10 & 0,01 & $0 \quad 0$ & 0 & 0,00 & 29 & 21 & 50 & 0,26 \\
\hline TOTAL & 59 & 30 & 89 & 0,46 & 47 & 51 & 98 & 0,50 & 202 & 411 & 613 & 3,14 & 935 & 363 & 1298 & 6,64 & 14 & $4 \quad 18$ & ${ }^{8} 0,09$ & 3 & 1 & ${ }^{4} 0$ & 0,02 & $\begin{array}{l}54 \\
\end{array}$ & 49 & 0,05 & 7861 & 11677 & 19538 & 100,00 \\
\hline
\end{tabular}


Tabela 12 - Flebotomíneos capturados em armadilhas de Shannon e CDC com e sem inseticida, segundo sexo, espécie e ambiente de captura, Assentamento Guaicurus, outubro/2002 a outubro/2003.

\begin{tabular}{|c|c|c|c|c|c|c|c|c|c|c|c|c|c|c|c|c|}
\hline \multirow[t]{3}{*}{ ESPÉCIE } & \multicolumn{12}{|c|}{ AMBIENTE } & & & & \\
\hline & \multicolumn{4}{|c|}{ Domicílio } & \multicolumn{4}{|c|}{ Peridomicílio } & \multicolumn{4}{|c|}{ Mata } & \multicolumn{4}{|c|}{ TOTAL } \\
\hline & $F$ & $M$ & $T$ & $\%$ & $F$ & $M$ & $T$ & $\%$ & $F$ & $M$ & $T$ & $\%$ & $F$ & $M$ & $\mathrm{~T}$ & $\%$ \\
\hline Brumptomyia avellari & 0 & 0 & 0 & 0,00 & 1 & 3 & 4 & 0,02 & 3 & 3 & 6 & 0,03 & 4 & 6 & 10 & 0,05 \\
\hline Brumptomyia brumpti & 0 & 1 & 1 & 0,01 & 2 & 6 & 8 & 0,04 & 6 & 2 & 8 & 0,04 & 8 & 9 & 17 & 0,09 \\
\hline Brumptomyia cunhai & 1 & 3 & 4 & 0,02 & 43 & 49 & 92 & 0,47 & 48 & 63 & 111 & 0,57 & 92 & 115 & 207 & 1,06 \\
\hline Brumptomyia sp & 0 & 0 & 0 & 0,00 & 5 & 0 & 5 & 0,03 & 4 & 0 & 4 & 0,02 & 9 & 0 & 9 & 0,05 \\
\hline Evandromyia corumbaensis & 10 & 4 & 14 & 0,07 & 34 & 0 & 34 & 0,17 & 59 & 5 & 64 & 0,33 & 103 & 9 & 112 & 0,57 \\
\hline Lutzomyia almerioi & 117 & 95 & 212 & 1,09 & 1304 & 831 & 2135 & 10,93 & 1160 & 435 & 1595 & 8,16 & 2581 & 1361 & 3942 & 20,18 \\
\hline Lutzomyia dispar & 0 & 0 & 0 & 0,00 & 0 & 0 & 0 & 0,00 & 1 & 0 & 1 & 0,01 & 1 & 0 & 1 & 0,01 \\
\hline Lutzomyia longipalpis & 107 & 232 & 339 & 1,74 & 4113 & 7849 & 11962 & 61,22 & 519 & 1320 & 1839 & 9,41 & 4739 & 9401 & 14140 & 72,37 \\
\hline Martinsmyia oliveirai & 0 & 0 & 0 & 0,00 & 5 & 2 & 7 & 0,04 & 39 & 19 & 58 & 0,30 & 44 & 21 & 65 & 0,33 \\
\hline Micropygomyia peresi & 1 & 0 & 1 & 0,01 & 1 & 0 & 1 & 0,01 & 20 & 6 & 26 & 0,13 & 22 & 6 & 28 & 0,14 \\
\hline Micropygomyia quinquefer & 0 & 1 & 1 & 0,01 & 5 & 2 & 7 & 0,04 & 16 & 9 & 25 & 0,13 & 21 & 12 & 33 & 0,17 \\
\hline Nyssomyia whitmani & 6 & 4 & 10 & 0,05 & 130 & 325 & 455 & 2,33 & 24 & 63 & 87 & 0,45 & 160 & 392 & 552 & 2,83 \\
\hline Pintomyia (P.) kuscheli & 2 & 0 & 2 & 0,01 & 6 & 0 & 6 & 0,03 & 10 & 0 & 10 & 0,05 & 18 & 0 & 18 & 0,09 \\
\hline Psathyromyia punctigeniculata & 0 & 1 & 1 & 0,01 & 9 & 4 & 13 & 0,07 & 4 & 0 & 4 & 0,02 & 13 & 5 & 18 & 0,09 \\
\hline Psathyromyia shannoni & 0 & 1 & 1 & 0,01 & 13 & 259 & 272 & 1,39 & 4 & 59 & 63 & 0,32 & 17 & 319 & 336 & 1,72 \\
\hline Sciopemyia sordellii & 1 & 2 & 3 & 0,02 & 18 & 6 & 24 & 0,12 & 10 & 13 & 23 & 0,12 & 29 & 21 & 50 & 0,26 \\
\hline TOTAL & 245 & 344 & 589 & 3,01 & 5689 & 9336 & 15025 & 76,90 & 1927 & 1997 & 3924 & 20,08 & 7861 & 11677 & 19538 & 100,00 \\
\hline
\end{tabular}

$F=$ fêmea

$M=$ macho

* provavelmente represente fêmea de uma das espécies de Brumptomyia encontradas no Assentamento Guaicurus 
Em relação ao número total de flebotomíneos capturados, a espécie predominante foi Lutzomyia longipalpis $(72,4 \%)$, seguida por Lutzomyia almerioi (20,2\%), Nyssomia whitmani (2,8\%), Psathyromyia shannoni (1,7\%), Brumptomyia cunhai (1,1\%), Evandromyia corumbaensis $(0,6 \%)$.

Lutzomyia longipalpis foi a espécie que predominou em 11 dos 14 lotes de captura, Lutzomyia almerioi predominou em 2 lotes e somente em um dos lotes, onde o número de flebotomíneos capturados foi muito pequeno (4 exemplares), Nyssomia whitmani predominou.

Em relação ao ambiente, considerando-se o total de flebotomineos capturados, o maior número de flebotomíneos foi encontrado no peridomicilio $(76,9 \%)$ e Lutzomyia longipalpis foi a espécie que predominou em todos os ambientes estudados.

De todos os pontos onde foram realizadas as coletas, no lote 19 capturou-se $58,4 \%$ e no lote $20,28,0 \%$ do total de espécimes. Portanto, esses dois lotes responderam por cerca de $86 \%$ do total capturado e localizam-se em uma mesma linha.

Os outros três locais que se destacaram pelo número de flebotomíneos capturados foram a gruta próxima ao lote 56 , o lote 124 e o lote 2 , representando, $6,64 \%, 3,14 \%$ e $1,48 \%$, respectivamente. As demais localidades contribuiram com apenas $2,4 \%$ do total de espécimes capturados. 


\subsubsection{Diversidade}

O total de flebotomíneos capturados, quinzenalmente, em armadilha CDC com inseticida, no período de novembro de 2002 a outubro de 2003 , os índices de diversidade e a média de flebotomíneos por captura encontram-se na tabela 13. 
Tabela 13 - Flebotomíneos capturados em armadilha automática luminosa com inseticida, segundo os sítios de captura e as espécies, Indice de Diversidade e Média de captura, novembro/02 a outubro/03.

\begin{tabular}{|c|c|c|c|c|c|c|c|c|c|c|c|c|c|c|c|c|c|}
\hline $\begin{array}{l}\text { Local de captura } \\
\text { Espécies }\end{array}$ & $\begin{array}{l}\text { L. } 35 \\
\text { Casa } \\
\end{array}$ & $\begin{array}{l}\text { L. } 35 \\
\text { Peri }\end{array}$ & $\begin{array}{l}\text { L. } 02 \\
\text { Peri }\end{array}$ & $\begin{array}{l}\text { L. } 02 \\
\text { Casa }\end{array}$ & $\begin{array}{l}\text { L. } 02 \\
\text { Mata }\end{array}$ & $\begin{array}{l}\text { L. } 20 \\
\text { Peri }\end{array}$ & $\begin{array}{l}\text { L. } 20 \\
\text { Casa }\end{array}$ & $\begin{array}{l}\text { L. } 20 \\
\text { Cultivo }\end{array}$ & $\begin{array}{l}\text { L. } 20 \\
\text { Mata }\end{array}$ & $\begin{array}{l}\text { L. } 59 \\
\text { Casa }\end{array}$ & $\begin{array}{l}\text { L. } 59 \\
\text { Peri }\end{array}$ & $\begin{array}{l}\text { L. } 102 \\
\text { Casa }\end{array}$ & $\begin{array}{l}\text { L.102 } \\
\text { Peri }\end{array}$ & $\begin{array}{l}\text { L. } 56 \\
\text { Gruta }\end{array}$ & $\begin{array}{l}\text { L.19 } \\
\text { Peri }\end{array}$ & $\begin{array}{l}\text { L.19 } \\
\text { Mata }\end{array}$ & $\begin{array}{l}\text { L. } 19 \\
\text { Casa } \\
\end{array}$ \\
\hline L. longipalpis & 5 & 4 & 54 & 4 & 47 & 141 & 132 & 156 & 1109 & 22 & 2 & 10 & 2 & 0 & 7836 & 174 & 40 \\
\hline L. almerioi & 0 & 1 & 2 & 0 & 3 & 32 & 10 & 3 & 286 & 7 & 3 & 0 & 0 & 322 & 658 & 22 & 2 \\
\hline N. whitmani & 0 & 0 & 3 & 0 & 4 & 17 & 0 & 7 & 56 & 0 & 2 & 2 & 0 & 0 & 346 & 10 & 3 \\
\hline P. shannoni & 0 & 0 & 2 & 0 & 1 & 5 & 1 & 0 & 39 & 0 & 0 & 0 & 0 & 0 & 189 & 19 & 0 \\
\hline$P$. punctigeniculata & 0 & 0 & 0 & 0 & 0 & 0 & 0 & 0 & 1 & 0 & 1 & 0 & 0 & 0 & 0 & 0 & 0 \\
\hline E. corumbaensis & 0 & 0 & 2 & 0 & 6 & 2 & 1 & 1 & 12 & 3 & 4 & 5 & 1 & 6 & 2 & 9 & 1 \\
\hline S. sordellii & 0 & 0 & 1 & 0 & 1 & 3 & 0 & 1 & 5 & 0 & 1 & 0 & 0 & 1 & 7 & 7 & 1 \\
\hline M. oliveirai & 0 & 0 & 0 & 0 & 0 & 2 & 0 & 0 & 7 & 0 & 0 & 0 & 0 & 20 & 0 & 3 & 0 \\
\hline P. kuscheli & 0 & 0 & 0 & 0 & 0 & 0 & 0 & 0 & 9 & 1 & 0 & 0 & 0 & 0 & 0 & 1 & 0 \\
\hline M. peresi & 0 & 0 & 0 & 0 & 0 & 0 & 1 & 0 & 9 & 0 & 0 & 0 & 0 & 0 & 1 & 1 & 0 \\
\hline M. quinquefer & 0 & 0 & 0 & 0 & 0 & 0 & 0 & 2 & 7 & 0 & 0 & 0 & 0 & 0 & 1 & 1 & 0 \\
\hline B. cunhai & 1 & 5 & 0 & 1 & 3 & 5 & 0 & 1 & 25 & 0 & 0 & 0 & 4 & 5 & 0 & 10 & 0 \\
\hline B. brumpti & 0 & 0 & 1 & 0 & 0 & 0 & 0 & 0 & 4 & 0 & 0 & 0 & 0 & 0 & 1 & 1 & 1 \\
\hline B. avellari & 0 & 0 & 0 & 0 & 1 & 0 & 0 & 0 & 0 & 0 & 0 & 0 & 0 & 0 & 1 & 2 & 0 \\
\hline Brumptomyia sp* & 0 & 0 & 0 & 0 & 0 & 0 & 0 & 0 & 2 & 0 & 0 & 0 & 0 & 0 & 0 & 0 & 0 \\
\hline L. dispar & 0 & 0 & 0 & 0 & 0 & 0 & 0 & 0 & 1 & 0 & 0 & 0 & 0 & 0 & 0 & 0 & 0 \\
\hline Total & 6 & 10 & 65 & 5 & 66 & 207 & 145 & 171 & 1572 & 33 & 13 & 17 & 7 & 354 & 9042 & 260 & 48 \\
\hline Média de captura** & 0,27 & 0,45 & 2,95 & 0,23 & 3,00 & $\mathbf{9 , 4 1}$ & 6,59 & 7,77 & 71,45 & 1,50 & 0,59 & 0,77 & 0,32 & 16,09 & 411,00 & 11,82 & 2,18 \\
\hline 1. Diversidade (D) & 0,56 & 0,87 & 1,44 & 0,62 & 1,67 & 1,31 & 0,80 & 1,17 & 1,77 & 0,86 & 1,95 & 0,71 & 1,03 & 0,68 & 0,99 & 2,16 & 1,29 \\
\hline
\end{tabular}

\section{$L=$ Lote}

" provavelmente represente fêmea de uma das espécies de Brumptomyia encontradas no Assentamento Guaicurus

** a média de captura foi feita considerando-se ter ocorrido duas capturas mensais em cada ponto no periodo de estudo, com exceçăo de novembro e dezembro de 2002, quando ocorreu apenas uma captura no més (foram 22 capturas no total do período). 


\begin{tabular}{|c|c|c|c|c|c|c|c|c|c|}
\hline $\begin{array}{l}\text { Local de captura } \\
\text { spécies }\end{array}$ & $\begin{array}{l}\text { Sede } \\
\text { Casa }\end{array}$ & $\begin{array}{l}\text { Sede } \\
\text { Peri }\end{array}$ & $\begin{array}{l}\text { L. } 110 \\
\text { Peri }\end{array}$ & $\begin{array}{l}\text { L. } 110 \\
\text { Cultive }\end{array}$ & Casa & Casa & Mata & $\begin{array}{l}\text { L. } 124 \\
\text { Peri }\end{array}$ & To \\
\hline longipalpis & 0 & 0 & 41 & 6 & 58 & 9 & 447 & 81 & 10380 \\
\hline almerioi & 0 & 0 & 1 & 1 & 0 & 0 & 20 & 3 & 1376 \\
\hline whitmani & 1 & 0 & 0 & 0 & 1 & 0 & 15 & 6 & 473 \\
\hline shannoni & 0 & 0 & 0 & 0 & 0 & 0 & 3 & 1 & 260 \\
\hline punctigeniculata & 0 & 0 & 0 & 0 & 1 & 0 & 0 & 0 & 3 \\
\hline corun & 0 & 0 & 0 & 0 & 0 & 1 & 10 & 0 & 66 \\
\hline sordellii & 0 & 1 & 0 & 0 & 3 & 0 & 4 & 2 & 38 \\
\hline oliveirai & 0 & 0 & 0 & 0 & 0 & 0 & 0 & 0 & 32 \\
\hline kuscheli & 0 & 0 & 1 & 0 & 1 & 0 & 0 & 1 & 4 \\
\hline peresi & 0 & 0 & 0 & 0 & 0 & 0 & 0 & 0 & 12 \\
\hline quinquefer & 0 & 0 & 0 & 0 & 0 & 0 & 0 & 0 & 11 \\
\hline cunhai & 0 & 0 & 8 & 6 & 1 & 0 & 5 & 0 & 80 \\
\hline brumpti & 0 & 0 & 0 & 0 & 0 & 0 & 1 & 0 & 9 \\
\hline avellari & 0 & 0 & 0 & 0 & 0 & 0 & 0 & 0 & 4 \\
\hline Brumptom & 0 & 0 & 0 & 0 & 0 & 0 & 0 & 0 & 2 \\
\hline dispar & 0 & 0 & 0 & 0 & 0 & 0 & 0 & 0 & 1 \\
\hline al & 1 & 1 & 51 & 13 & 65 & 10 & 505 & 94 & 12761 \\
\hline Média & 0,05 & 0,05 & 2,32 & 0,59 & 2,95 & 0,45 & 22,95 & 4,27 & 580,05 \\
\hline Diversidade (D) & 0,00 & 0,00 & 0,76 & 0,78 & 1,20 & 0,43 & 1,12 & 1,10 & 1,59 \\
\hline
\end{tabular}


Os indices de diversidade das espécies de flebotomíneos variou de 1,12 a 2,16 nas matas, de 0,76 a 1,95 nos peridomicilios e de 0,43 a 1,29 nos domicílios, sendo que nestes, em sua maioria, foi menor que 1,00.

Cabe ressaltar que o indice de diversidade sofre influência não só do número de espécies encontradas em determinado local, mas também do número de espécimes. Assim, pôde-se observar índices mais elevados, como no peridomicílio do lote $59(1,95)$, onde foram observadas 6 espécies entre os 13 espécimes capturados, do que os encontrados em alguns locais, como na mata do lote $20(1,77)$, onde foram encontradas 14 espécies entre os 1572 flebotomineos capturados.

O indice de diversidade das espécies nas matas, em geral, foi mais alto, em virtude do número mais elevado de espécies e as freqüências não serem tão elevadas, enquanto que, nos domicilios foi baixo. No peri e intradomicílio da sede do Assentamento o índice foi zero.

\subsubsection{Sazonalidade}

A distribuição mensal dos 12761 espécimes de flebotomíneos capturados em armadilha automática luminosa com inseticida no Assentamento Guaicurus e das chuvas registradas no mesmo periodo, novembro de 2002 a outubro de 2003, no Municipio de Bonito está demonstrada na figura 21. 


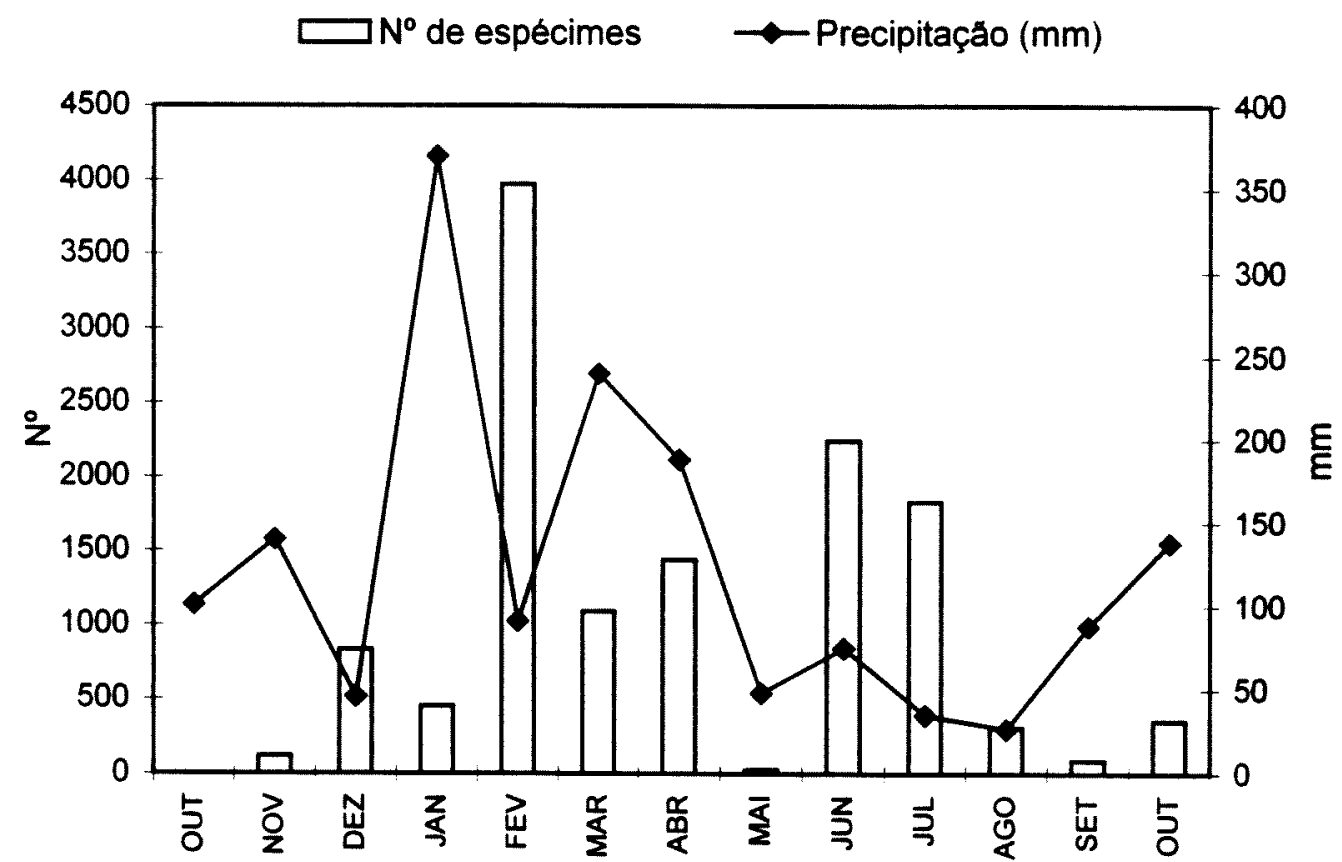

Figura 21 - Total de flebotomíneos capturados, mensalmente, em armadilha CDC com veneno e precipitação mensal no Município de Bonito - MS, novembro/02 a outubro/03.

A distribuição mensal das chuvas ocorridas no periodo de abril de 2002 a outubro de 2003 e da média mensal do período de 1981 a 2003, encontram-se no anexo 5.

As médias geométricas de Williams obtidas para Lutzomyia longipalpis, Lutzomyia almerioi e Nyssomia whitmani, espécies mais freqüentes no Assentamento, segundo os ambientes de captura com armadilhas automáticas luminosas com inseticida, encontram-se na tabela 14. 
Tabela 14 - Média de Williams para as três espécies de flebotomineos mais freqüentes do Assentamento Guaicurus, segundo os ambientes de captura com CDC com inseticida, novembro de 2002 a outubro de 2003.

\begin{tabular}{l|ccccc}
\hline \multicolumn{1}{c|}{$\begin{array}{l}\text { Ambiente } \\
\text { Espécie }\end{array}$} & Mata & Cultivo & Peridomicilio & Intradomicilio & Total \\
\hline$N^{0}$ de pontos & 4 & 2 & 9 & 9 & 24 \\
\hline Lu. longipalpis & 253,23 & 32,15 & 26,66 & 13,26 & 30,70 \\
Lu. almerioi & 26,29 & 1,83 & 4,44 & 0,86 & 3,51 \\
Ny. whitmani & 13,97 & 1,83 & 3,32 & 0,54 & 2,48 \\
\hline
\end{tabular}

As médias geométricas de Williams encontradas, mensalmente, para machos e fêmeas dessas espécies no total dos sítios de captura com armadilhas automáticas luminosas com inseticida, estão apresentadas na tabela 15.

Essas médias de Williams e a distribuição mensal das chuvas no Município de Bonito, de novembro de 2002 a outubro de 2003, encontramse na figura 22 . 
Tabela 15 - Média de Williams mensal de Lu. longipalpis, Ny. whitmani e Lu. almerioi, capturadas com CDC com inseticida, Assentamento Guaicurus, novembro de 2002 a outubro de 2003.

\begin{tabular}{|c|c|c|c|c|c|c|}
\hline Espécie & Lu. IoI & ipalpis & $\overline{N y . u}$ & itmani & Lu.a & nerioi \\
\hline Meses & Machos & Fêmeas & Machos & Fêmeas & Machos & Fêmeas \\
\hline Novembro & 0,78 & 0,53 & 0,03 & 0,00 & 0,11 & 0,25 \\
\hline Dezembro & 1,76 & 1,07 & 0,00 & 0,03 & 0,60 & 0,87 \\
\hline Janeiro & 0,54 & 0,44 & 0,04 & 0,00 & 0,15 & 0,20 \\
\hline Fevereiro & 1,08 & 1,22 & 0,21 & 0,12 & 0,43 & 0,95 \\
\hline Março & 0,73 & 0,50 & 0,13 & 0,14 & 0,14 & 0,17 \\
\hline Abril & 0,71 & 0,59 & 0,13 & 0,15 & 0,10 & 0,21 \\
\hline Maio & 0,15 & 0,08 & 0,00 & 0,00 & 0,04 & 0,01 \\
\hline Junho & 0,61 & 0,47 & 0,23 & 0,12 & 0,16 & 0,27 \\
\hline Julho & 1,29 & 0,78 & 0,38 & 0,14 & 0,16 & 0,31 \\
\hline Agosto & 0,49 & 0,20 & 0,07 & 0,08 & 0,17 & 0,19 \\
\hline Setembro & 0,29 & 0,18 & 0,00 & 0,01 & 0,07 & 0,14 \\
\hline Outubro & 0,17 & 0,12 & 0,00 & 0,00 & 0,12 & 0,22 \\
\hline
\end{tabular}


$\longrightarrow$ Machos $\rightarrow$-Fêmeas $\rightarrow$ - Precipitação mensal (mm)

\section{Lu. longipalpis}
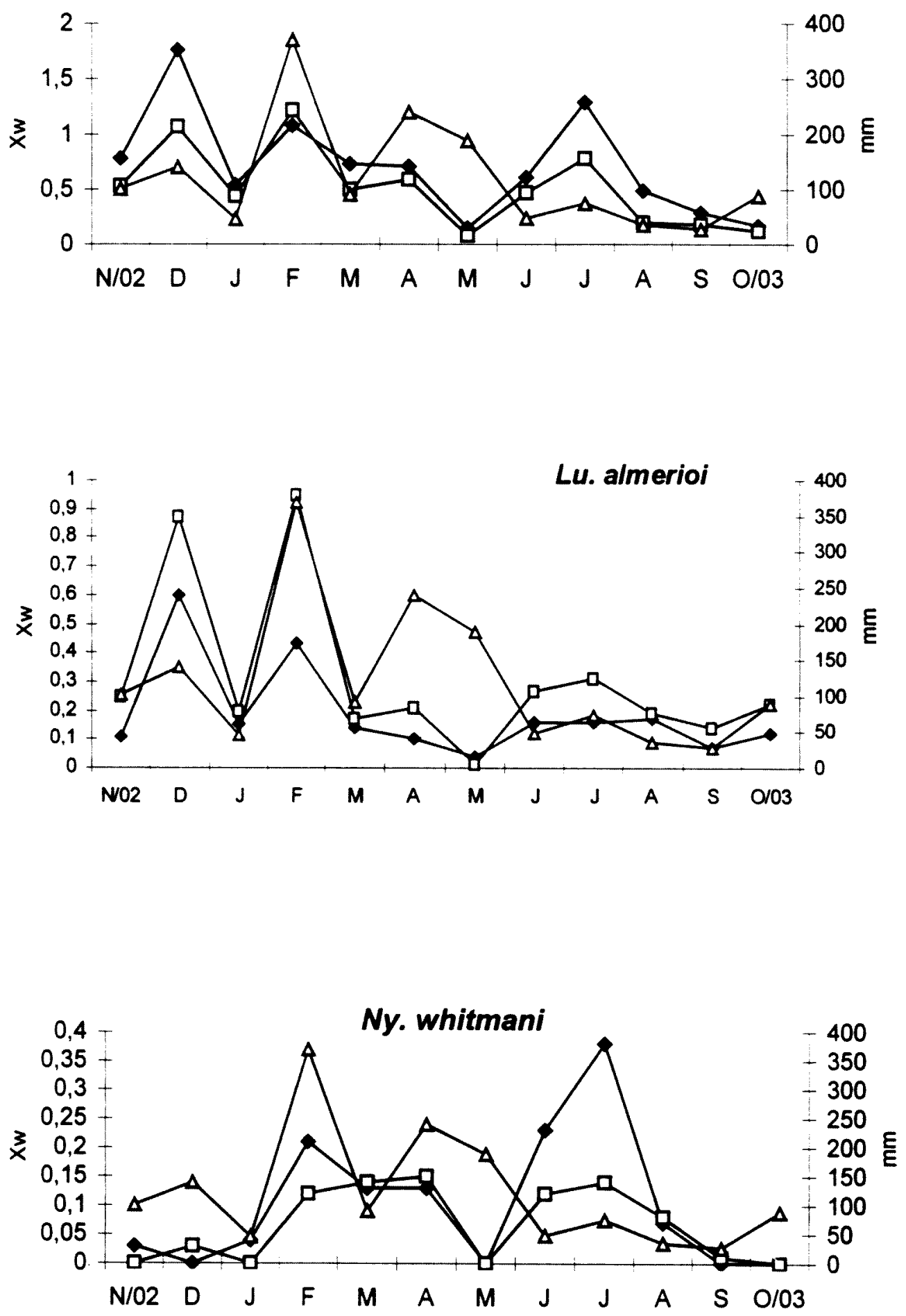

Figura 22 - Média de Williams mensal de Lu. longipalpis, Ny. whitmani e Lu. almerioi, Assentamento Guaicurus e precipitação mensal no Município de Bonito, novembro/2002 a outubro/2003. 
As médias geométricas de Williams mensais observadas para machos e fêmeas de Lutzomyia longipalpis, Lutzomyia almerioi e Nyssomia whitmani em alguns ecótopos do Assentamento encontram-se nas tabelas 16 a 18 e figuras 23 a 25.

As médias de Williams obtidas, mensalmente, por sexo para cada local de captura estão dispostas nos anexos 6 ao 11 . 
Tabela 16 - Média de Williams para machos e fêmeas de Lu. longipalpis para alguns ecótopos, novembro de 2002 a outubro de 2003.

\begin{tabular}{|c|c|c|c|c|c|c|c|c|c|c|c|c|}
\hline \multirow{4}{*}{$\begin{array}{l}\text { L } 19 \text { - peri } \\
\text { Machos } \\
\text { Fêmeas }\end{array}$} & \multicolumn{12}{|c|}{ Meses } \\
\hline & & & & & & & & & & & & \\
\hline & 0,0 & 286,7 & 15,9 & 566,5 & 297,5 & 228,1 & 1,2 & 571,8 & 16,5 & 27,1 & 0,0 & 0,0 \\
\hline & 00 & 1710 & 4.8 & 807,2 & 69,2 & 99,2 & 2,5 & 223,9 & 10,2 & 6,8 & 0,0 & 3,6 \\
\hline Machos & 0,0 & 0,0 & 0,0 & 0,0 & 0,0 & 0,0 & 0,0 & 0,0 & 0,0 & 0,0 & 0,0 & 0,0 \\
\hline Fêmeas & 0,0 & 0,0 & 0,0 & 0,0 & 0,0 & 0,0 & 0,0 & 0,0 & 0,0 & 0,0 & 0,0 & 0,0 \\
\hline L 20 - casa & & & & & & & & & & & & \\
\hline Machos & 0,0 & 1,0 & 0,0 & 0,0 & 0,7 & 0,4 & 0,0 & 1,7 & 7,6 & 2,5 & 0,4 & 0,7 \\
\hline Fêmeas & 0,0 & 0,0 & 0,0 & 2,5 & 0,0 & 1,0 & 0,0 & 2,5 & 4,2 & 0,4 & 0,0 & 0,0 \\
\hline Machos & 4,0 & 4,0 & 0,4 & 23,5 & 2,3 & 11,3 & 0,4 & 6,3 & 20 & 1,2 & 0,0 & 1,0 \\
\hline Fêmeas & 1,0 & 1,0 & 0,4 & 20,2 & 1,0 & 0,0 & 0,4 & 5,0 & 10,8 & 0,7 & 1,0 & 0,4 \\
\hline
\end{tabular}

$$
\mathrm{L}=\mathrm{Lote}
$$



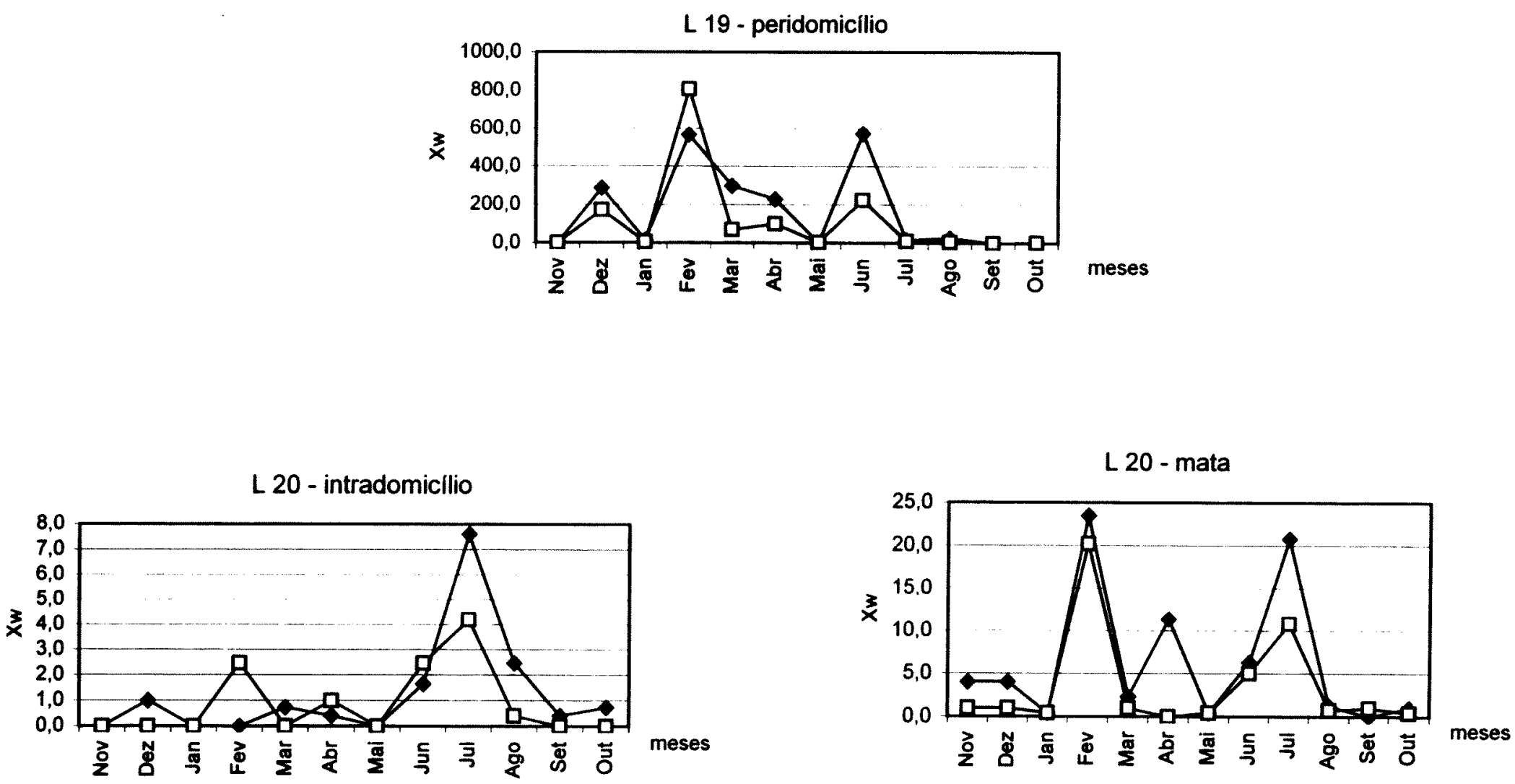

Figura 23 - Média de Williams para machos e fêmeas de Lu. longipalpis para alguns ecótopos, novembro/02 a outubro/03. 
Tabela 17 - Média de Williams para machos e fêmeas de Lu. almerioi para alguns ecótopos, novembro de 2002 a outubro de 2003.

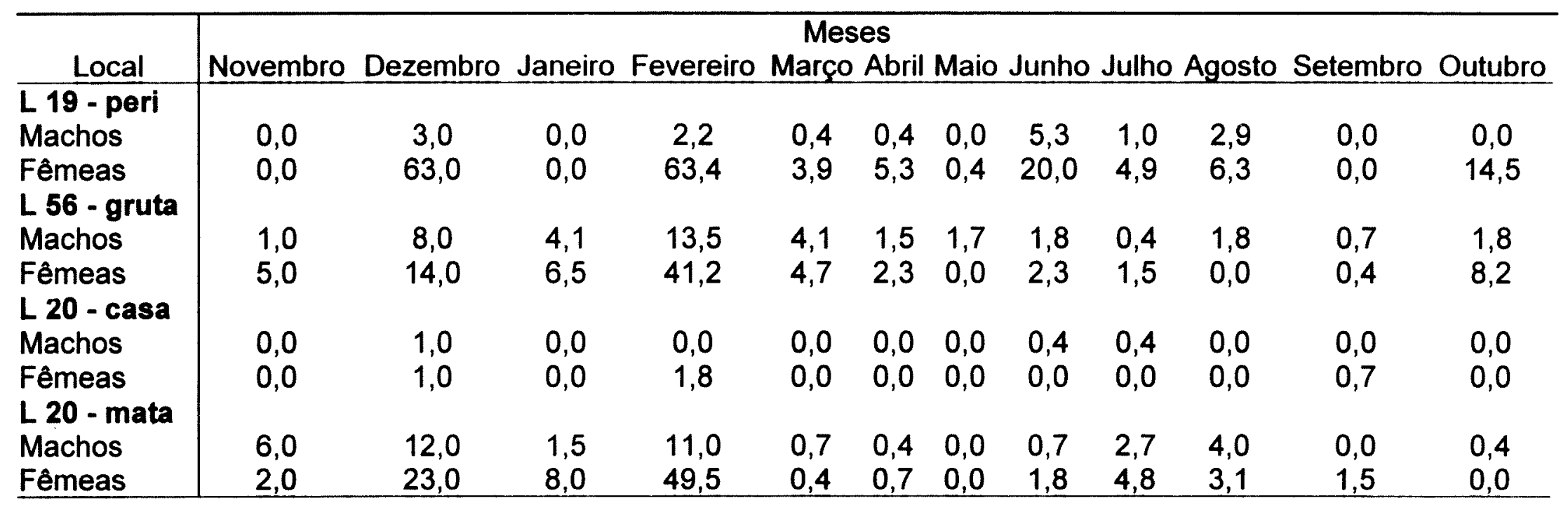

$L=$ Lote 
Lote 19 - peridomiclio

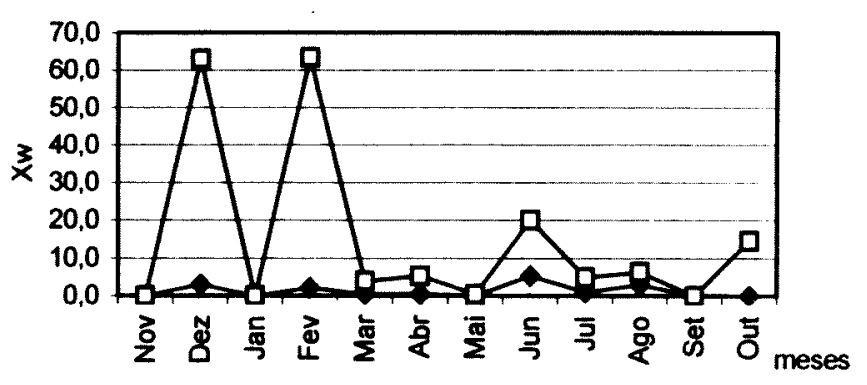

Lote 20 - intradomicílio

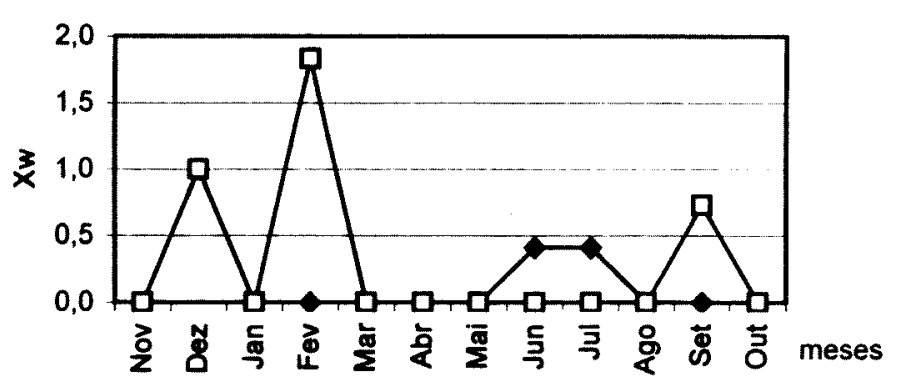

Lote 56 - gruta do Olimpio

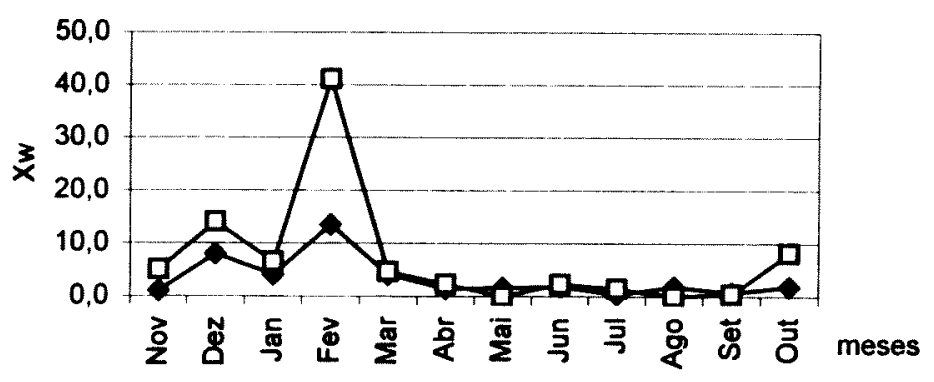

Lote 20 - mata

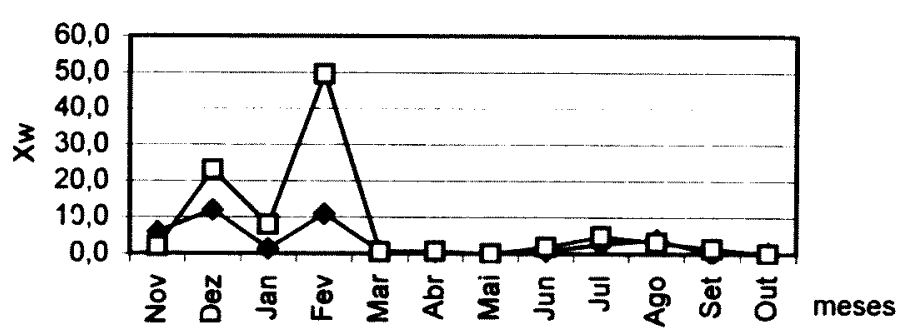

Figura 24 - Média de Williams para machos e fêmeas de Lu. almerioi para alguns ecótopos, novembro/02 a outubro/03. 
Tabela 18 - Média de Williams para machos e fêmeas de $\mathbf{N y}$. whitmani para alguns ecótopos, novembro de 2002 a outubro de 2003.

\begin{tabular}{|c|c|c|c|c|c|c|c|c|c|c|c|c|}
\hline Local & Novembro & Dezembro & Janeiro & Fevereiro & $\begin{array}{r}\text { Mes } \\
\text { Março }\end{array}$ & Abril & Maio & Junho & Julho & Agosto & Setembro & Outubro \\
\hline $\begin{array}{l}\text { L } 19 \text { - peri } \\
\text { Machos }\end{array}$ & 0,0 & 0,0 & 0,7 & 17,3 & 6,1 & 14,5 & 0,0 & 55,5 & 5,2 & 0,7 & 0,0 & 0,0 \\
\hline $\begin{array}{l}\text { Fêmeas } \\
\text { L } 56 \text { - gruta }\end{array}$ & 0,0 & 0,0 & 0,0 & 7,4 & 6,4 & 6,4 & 0,0 & 14,2 & 0,0 & 1,0 & 0,0 & 0,0 \\
\hline Machos & 0,0 & 0,0 & 0,0 & 0,0 & 0,0 & 0,0 & 0,0 & 0,0 & 0,0 & 0,0 & 0,0 & 0,0 \\
\hline $\begin{array}{l}\text { Fêmeas } \\
\text { L } 20 \text { - casa }\end{array}$ & 0,0 & 0,0 & 0,0 & 0,0 & 0,0 & 0,0 & 0,0 & 0,0 & 0,0 & 0,0 & 0,0 & 0,0 \\
\hline Machos & 0,0 & 0,0 & 0,0 & 0,0 & 0,0 & 0,0 & 0,0 & 0,0 & 0,0 & 0,0 & 0,0 & 0,0 \\
\hline $\begin{array}{l}\text { Fêmeas } \\
\text { L } 20 \text { - mata }\end{array}$ & 0,0 & 0,0 & 0,0 & 0,0 & 0,0 & 0,0 & 0,0 & 0,0 & 0,0 & 0,0 & 0,0 & 0,0 \\
\hline $\begin{array}{l}\text { Machos } \\
\text { Fêmeas }\end{array}$ & $\begin{array}{l}0,0 \\
0,0\end{array}$ & $\begin{array}{l}0,0 \\
0,0 \\
\end{array}$ & $\begin{array}{l}0,0 \\
0,0\end{array}$ & $\begin{array}{l}0,0 \\
0,0 \\
\end{array}$ & $\begin{array}{l}0,0 \\
0,0 \\
\end{array}$ & $\begin{array}{l}0,0 \\
1,5 \\
\end{array}$ & $\begin{array}{l}0,0 \\
0,0 \\
\end{array}$ & $\begin{array}{l}0,0 \\
0,0 \\
\end{array}$ & $\begin{array}{l}5,4 \\
2,3 \\
\end{array}$ & $\begin{array}{l}0,4 \\
0,0 \\
\end{array}$ & $\begin{array}{l}0,0 \\
0,0 \\
\end{array}$ & $\begin{array}{l}0,0 \\
0,0 \\
\end{array}$ \\
\hline
\end{tabular}

$L=$ Lote 


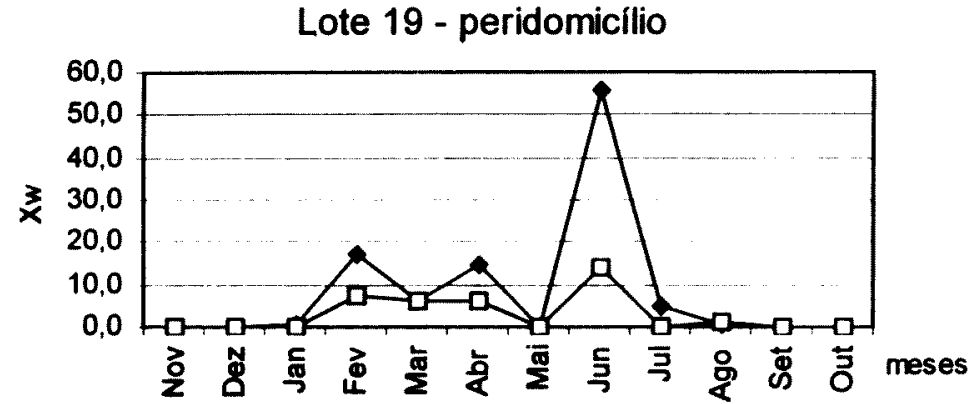

Lote 20 - mata

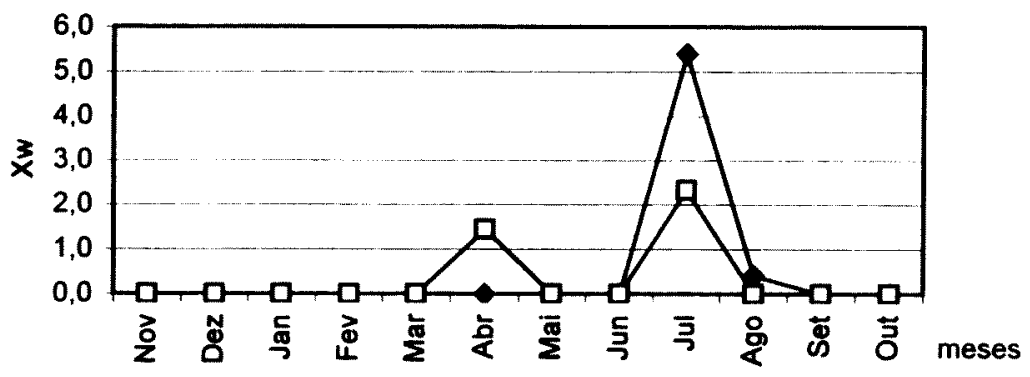

Figura 25 - Média de Williams para machos e fêmeas de Ny. whitmani para alguns ecótopos, novembro/02 a outubro/03. 


\subsubsection{Abundância}

O indice de abundância padronizado está disposto na tabela 19.

Tabela 19 - Índice de Abundância da Espécie Padronizado (IAEP) dos flebotomíneos capturados em CDC com veneno, Assentamento Guaicurus, novembro/2002 a outubro/2003.

\begin{tabular}{lcc}
\hline Espécies & IAEP & Posição \\
\hline Lutzomyia longipalpis & 0,866 & $1^{\mathrm{a}}$ \\
Lutzomyia almerioi & 0,606 & $2^{\mathrm{a}}$ \\
Evandromyia corumbaensis & 0,506 & $3^{\mathrm{a}}$ \\
Nyssomyia whitmani & $0,4 \Omega 0$ & $4^{\mathrm{a}}$ \\
Brumptomyia cunhai & 0,468 & $5^{\mathrm{a}}$ \\
Sciopemyia sordellii & 0,386 & $6^{\mathrm{a}}$ \\
Psathyromyia shannoni & 0,266 & $7^{\mathrm{a}}$ \\
Pintomyia (P.) kuscheli & 0,156 & $8^{\mathrm{a}}$ \\
Brumptomyia brumpti & 0,114 & $9^{\mathrm{a}}$ \\
Martinsmyia oliveirai & 0,097 & $10^{\mathrm{a}}$ \\
Micropygomyia peresi & 0,084 & $11^{\mathrm{a}}$ \\
Micropygomyia quinquefer & 0,079 & $12^{\mathrm{a}}$ \\
Brumptomyia avellari & 0,061 & $13^{\mathrm{a}}$ \\
Psathyromyia punctigeniculata & 0,061 & $13^{\mathrm{a}}$ \\
Brumptomyia sp & 0,007 & $14^{\mathrm{a}}$ \\
Lutzomyia dispar & 0,003 & $15^{\mathrm{a}}$ \\
\hline
\end{tabular}

A espécie de flebotomíneo mais abundante no Assentamento Guaicurus foi Lutzomyia longipalpis, seguida por Lutzomyia almerioi, Evandromyia corumbaensis e Nyssomia whitmani. 


\subsubsection{Infecção natural por Leishmania}

\subsubsection{Métodos convencionais}

Os números de fêmeas dissecadas e encontradas infectadas, ao microscópio ótico, conforme as espécies e os lotes de captura, podem ser vistos na tabela 20 . 
Tabela 20 - Número de fêmeas de flebotomineos dissecadas e infectadas por flagelados, conforme observação microscópica, segundo espécie e o lote de captura, Assentamento Guaicurus, outubro/02 a outubro/03.

\begin{tabular}{|c|c|c|c|c|c|c|c|c|c|c|c|c|c|c|c|c|c|c|c|c|c|}
\hline \multirow[b]{3}{*}{ Espécie } & \multicolumn{18}{|c|}{ Lote } & \multirow{2}{*}{\multicolumn{3}{|c|}{ Total }} \\
\hline & \multicolumn{2}{|c|}{2} & \multicolumn{2}{|c|}{19} & \multicolumn{2}{|c|}{20} & \multicolumn{2}{|c|}{40} & \multicolumn{2}{|c|}{56} & \multicolumn{2}{|c|}{60} & \multicolumn{2}{|c|}{110} & \multicolumn{2}{|c|}{115} & \multicolumn{2}{|c|}{124} & & & \\
\hline & Dis & Inf & Dis & $\operatorname{lnf}$ & Dis & Inf & Dis & $\operatorname{lnf}$ & Dis & $\operatorname{lnf}$ & Dis & Inf & Dis & $\operatorname{lnf}$ & Dis & Inf & Dis & $\operatorname{lnf}$ & Dis & Inf & $\%$ \\
\hline Brumptomyia avellari & 0 & 0 & 1 & 0 & 0 & 0 & 0 & 0 & 0 & 0 & 0 & 0 & 0 & 0 & 0 & 0 & 0 & 0 & 1 & 0 & 0 \\
\hline Brumptomyia cunhai & 3 & 0 & 12 & 0 & 1 & 0 & 0 & 0 & 0 & 0 & 0 & 0 & 3 & 0 & 0 & 0 & 0 & 0 & 19 & 0 & 0 \\
\hline Brumptomyia sp* & 1 & 0 & 4 & 0 & 2 & 0 & 0 & 0 & 0 & 0 & 0 & 0 & 0 & 0 & 0 & 0 & 0 & 0 & 7 & 0 & 0 \\
\hline Evandromyia corumbaensis & 2 & 0 & 5 & 0 & 18 & 0 & 0 & 0 & 0 & 0 & 1 & 0 & 0 & 0 & 0 & 0 & 0 & 0 & 26 & 0 & 0 \\
\hline Lutzomyia almerioi & 2 & 0 & 50 & 0 & 590 & 3 & 2 & 0 & 183 & 0 & 2 & 0 & 0 & 0 & 7 & 0 & 0 & 0 & 836 & 3 & 0,36 \\
\hline Lutzomyia longipalpis & 2 & 0 & 281 & 0 & 145 & 0 & 2 & 0 & 3 & 0 & 1 & 0 & 0 & 0 & 2 & 0 & 2 & 0 & 438 & 0 & 0 \\
\hline Martinsmyia oliveirai & 0 & 0 & 2 & 0 & 5 & 0 & 0 & 0 & 1 & 0 & 0 & 0 & 0 & 0 & 0 & 0 & 0 & 0 & 8 & 0 & 0 \\
\hline Micropygomyia peresi & 0 & 0 & 0 & 0 & 13 & 0 & 0 & 0 & 0 & 0 & 0 & 0 & 0 & 0 & 0 & 0 & 0 & 0 & 13 & 0 & 0 \\
\hline Micropygomyia quinquefer & 0 & 0 & 2 & 0 & 11 & 0 & 0 & 0 & 0 & 0 & 0 & 0 & 0 & 0 & 0 & 0 & 0 & 0 & 13 & 0 & 0 \\
\hline Nyssomyia whitmani & 0 & 0 & 6 & 0 & 8 & 0 & 0 & 0 & 0 & 0 & 0 & 0 & 0 & 0 & 0 & 0 & 0 & 0 & 14 & 0 & 0 \\
\hline Pintomyia (P.) kuscheli & 0 & 0 & 0 & 0 & 4 & 0 & 0 & 0 & 0 & 0 & 0 & 0 & 0 & 0 & 0 & 0 & 0 & 0 & 4 & 0 & 0 \\
\hline Psathyromyia punctigeniculata & 0 & 0 & 1 & 0 & 5 & 0 & 0 & 0 & 2 & 0 & 1 & 0 & 0 & 0 & 0 & 0 & 0 & 0 & 9 & 0 & 0 \\
\hline Sciopemyia sordellii & 0 & 0 & 1 & 0 & 5 & 0 & 0 & 0 & 0 & 0 & 0 & 0 & 0 & 0 & 0 & 0 & 0 & 0 & 6 & 0 & 0 \\
\hline Sciopemyia sp & 0 & 0 & 0 & 0 & 1 & 0 & 0 & 0 & 0 & 0 & 0 & 0 & 0 & 0 & 0 & 0 & 0 & 0 & 1 & 0 & 0 \\
\hline Total & 10 & 0 & 365 & 0 & 808 & 3 & 4 & 0 & 189 & 0 & 5 & 0 & 3 & 0 & 9 & 0 & 2 & 0 & 1395 & 3 & 0,22 \\
\hline
\end{tabular}


Entre as fêmeas dissecadas, foram observadas ao microscópio 3 fêmeas de Lutzomyia almerioi infectadas por flagelados, capturadas no lote 20. A taxa de infecção encontrada em Lutzomyia almerioi foi de $0,36 \%$. No lote 20 , a taxa de infecção foi de $0,51 \%(3 / 590)$, sendo de $0,42 \%(2 / 475)$ no peridomicílio e 1,27\% (1/79) no intradomicilio.

A tentativa de cultivo em meios especificos dos protozoários encontrados nas 3 fêmeas de Lutzomyia almerioi, não obteve sucesso.

\subsubsection{Métodos moleculares}

Foram extraídos DNA de 1220 fêmeas dissecadas, sendo 808 de Lutzomyia almerioi, 399 de Lutzomyia longipalpis e 13 de Nyssomyia whitmani, distribuidas em 109 frascos contendo de uma a 50 fêmeas.

A distribuição das fêmeas dissecadas analisadas por PCR com os oligonucleotídeos $\mathrm{S17}$ e $\mathrm{S18}$, e o resultado obtido, conforme o local de captura, encontram-se na tabela 21. As respectivas taxas de infecção por Leishmania encontradas estão demonstradas na tabela 22. 
Tabela 21 - Número de fêmeas dissecadas e encontradas infectadas pela PCR com oligonucleotídeos S17 e S18, segundo local de captura no Assentamento Guaicurus, 2002-2003.

\begin{tabular}{|c|c|c|c|c|c|c|c|c|c|c|c|c|c|c|c|c|c|c|c|c|c|c|c|c|c|c|c|c|}
\hline \multirow[b]{2}{*}{ Espécies } & \multicolumn{2}{|c|}{$\begin{array}{l}\text { L. } 2 \\
\text { peri }\end{array}$} & \multicolumn{2}{|c|}{$\begin{array}{l}\text { L.19 } \\
\text { peri }\end{array}$} & \multicolumn{2}{|c|}{$\begin{array}{l}\text { L.19 } \\
\text { casa }\end{array}$} & \multicolumn{2}{|c|}{$\begin{array}{l}\text { L.19 } \\
\text { mata }\end{array}$} & \multicolumn{2}{|c|}{$\begin{array}{l}\text { L.20 } \\
\text { peri }\end{array}$} & \multicolumn{2}{|c|}{$\begin{array}{l}\text { L.20 } \\
\text { casa }\end{array}$} & \multicolumn{2}{|c|}{$\begin{array}{c}\text { L. } 20 \\
\text { cultivo }\end{array}$} & \multicolumn{2}{|c|}{$\begin{array}{l}\text { L.20 } \\
\text { gruta }\end{array}$} & \multicolumn{2}{|c|}{$\begin{array}{l}\text { L.20 } \\
\text { mata }\end{array}$} & \multicolumn{2}{|c|}{$\begin{array}{l}\text { L.40 } \\
\text { peri }\end{array}$} & \multicolumn{2}{|c|}{$\begin{array}{l}\text { L.56 } \\
\text { gruta }\end{array}$} & \multicolumn{2}{|c|}{$\begin{array}{l}\text { L.60 } \\
\text { peri }\end{array}$} & \multicolumn{2}{|c|}{$\begin{array}{c}\text { L.115 } \\
\text { peri }\end{array}$} & \multicolumn{2}{|c|}{ Total } \\
\hline & Dis & Inf & Dis & Inf & Dis & Inf & Dis & Inf & Dis & Inf & Dis & Inf & Dis & Inf & Dis & Inf & Dis & Inf & Dis & Inf & Dis & Inf & Dis & Inf & Dis & Inf & Dis & Inf \\
\hline Lu. almerioi & 0 & 0 & 41 & 0 & 0 & 0 & 3 & 1 & 464 & $2^{*}$ & 73 & $1^{*}$ & 0 & 0 & 22 & 0 & 3 & 0 & 2 & 0 & 194 & 0 & 2 & 0 & 4 & 0 & 808 & 4 \\
\hline Lu. longipalpis & 2 & 1 & 242 & 3 & 12 & 0 & 1 & 0 & 115 & 5 & 8 & 1 & 13 & 0 & 0 & 0 & 1 & 0 & 0 & 0 & 3 & 1 & 1 & 0 & 1 & 0 & 399 & 11 \\
\hline Ny. whitmani & 0 & 0 & 3 & 0 & 0 & 0 & 1 & 0 & 9 & 0 & 0 & 0 & 0 & 0 & 0 & 0 & 0 & 0 & 0 & 0 & 0 & 0 & 0 & 0 & 0 & 0 & 13 & 0 \\
\hline Total & 2 & 1 & 286 & 3 & 12 & 0 & 5 & 1 & 588 & 7 & 81 & 2 & 13 & 0 & 22 & 0 & 4 & 0 & 2 & 0 & 197 & 1 & 3 & 0 & 5 & 0 & 1220 & 15 \\
\hline
\end{tabular}

$$
\begin{aligned}
& \text { L. = lote } \\
& \text { Dis = dissecadas } \\
& \text { Inf = infectadas }
\end{aligned}
$$

* Na observação ao microscópio ótico, quando da dissecção das fêmeas no campo, uma fêmea capturada no peridomicilio e uma no domicílio do lote 20 , já haviam sido observadas infectadas por flagelados. 
Tabela 22 - Taxas de infecção natural por Leishmania em fêmeas de flebotomíneos pesquisadas por meio da PCR com os oligonucleotídeos S17 e S18, segundo local de captura no Assentamento Guaicurus, 2002-2003.

\begin{tabular}{l|cccccc|c}
\hline \multirow{4}{*}{ Local } & L. 2 & L. 19 & L. 19 & L. 20 & L. 20 & L. 56 & Total \\
Espécie & peri & peri & mata & peri & casa & gruta & \\
\hline Lu. almerioi & $\%$ & $\%$ & $\%$ & $\%$ & $\%$ & $\%$ & $\%$ \\
\hline \multirow{4}{*}{ Lu. longipalpis } & - & 0,00 & 33,30 & 0,43 & 1,37 & 0,00 & 0,50 \\
& & $(0 / 41)$ & $(1 / 3)$ & $(2 / 464)$ & $(1 / 73)$ & $(0 / 194)$ & $(4 / 808)$ \\
& 50,00 & 1,24 & 0,00 & 4,35 & 12,50 & 33,30 & 2,76 \\
& $(1 / 2)$ & $(3 / 242)$ & $(0 / 1)$ & $(5 / 115)$ & $(1 / 8)$ & $(1 / 3)$ & $(11 / 399)$ \\
& - & 0,00 & 0,00 & 0,00 & - & - & 0,00 \\
& & $(0 / 3)$ & $(0 / 1)$ & $(0 / 9)$ & & & $(0 / 13)$ \\
\hline Total & 50,00 & 1,05 & 20,00 & 1,19 & 2,47 & 0,51 & 1,23 \\
& $(1 / 2)$ & $(3 / 286)$ & $(1 / 5)$ & $(7 / 588)$ & $(2 / 81)$ & $(1 / 197)$ & $(15 / 1220)$ \\
\hline
\end{tabular}

peri $=$ peridomicilio $L=$ lote

As PCR realizadas empregando-se os oligonucleotideos para G6PD foram todas negativas. Nas reações com os oligonucleotídeos S4 e S12 foram encontradas 20 amostras positivas para tripanossomatídeos e com a "nested"-PCR (oligonucleotídeos S17/S18) confirmou-se a presença de 15 amostras positivas para Leishmania.

Considerando-se haver somente uma fêmea infectada em cada pool (PEREZ et al. 1994; MIRANDA et al. 2002), a taxa de infecção por Leishmania obtida por detecção molecular foi de $0,50 \%$ (4/808) em Lutzomyia almerioi e 2,76\% (11/399) em Lutzomyia longipalpis 
As taxas de infecção natural dos flebotomineos conforme a espécie de Leishmania encontram-se na tabela 23.

Tabela 23 - Taxas de infecção natural em fêmeas de flebotomíneos pesquisadas por meio da PCR com oligonucleotideos S17/S18, conforme a espécie de Leishmania e local de captura no Assentamento Guaicurus, 2002-2003.

\begin{tabular}{|c|c|c|c|c|c|c|c|c|c|c|c|c|c|}
\hline \multirow[b]{2}{*}{ Espécie } & \multicolumn{2}{|c|}{$\begin{array}{c}\text { Lote } 19 \\
\text { peri }\end{array}$} & \multicolumn{2}{|c|}{$\begin{array}{c}\text { Lote } 19 \\
\text { mata }\end{array}$} & \multicolumn{2}{|c|}{$\begin{array}{c}\text { Lote } 20 \\
\text { peri }\end{array}$} & \multicolumn{2}{|c|}{$\begin{array}{c}\text { Lote } 20 \\
\text { casa }\end{array}$} & \multicolumn{2}{|c|}{$\begin{array}{c}\text { Lote } 2 \\
\text { peri }\end{array}$} & \multicolumn{3}{|c|}{ Total } \\
\hline & Dis. & Id. & Dis. & Id. & Dis. & Id. & Dis. & Id. & Dis. & Id. & Dis. & Id. & $\%$ \\
\hline Lu. almerioi & 41 & 0 & 3 & 1 & 464 & 2 & 73 & 1 & 0 & 0 & 808 & 4 & 0,50 \\
\hline Lu. longipalpis & 242 & 3 & 1 & 0 & 115 & 2 & 8 & 1 & 2 & 1 & 399 & 7 & 1,75 \\
\hline Ny. whitmani & 3 & 0 & 1 & 0 & 9 & 0 & 0 & 0 & 0 & 0 & 13 & 0 & 0,00 \\
\hline Total & 286 & 3 & 5 & 1 & 588 & 4 & 81 & 2 & 2 & 1 & 1220 & 11 & 0,90 \\
\hline
\end{tabular}

\section{Infecção}

L.(L.)chagasi

Lu. almerioi

$\begin{array}{lll}1 & 1 & 1\end{array}$

Lu. longipalpis

$\begin{array}{lll}808 & 3 & 0,37\end{array}$

L.(L.) amazonensis

Lu. longipalpis

L.(Viannia) sp

Lu. almerioi

Lu. longipalpis

1

$\begin{array}{lll}399 & 1 & 0,25\end{array}$

Dis: Uissecaaas

Id: Identificadas

Foram encontradas três fêmeas de Lutzomyia almerioi infectadas por Leishmania (L.) chagasi e uma infectada por Leishmania (Viannia) sp.

Entre as fêmeas de Lutzomyia longipalpis, foram detectadas quatro infectadas por Leishmania (L.) amazonensis, duas por L. (Viannia) sp e uma por L. (L.) chagasi. Em quatro amostras de Lu. longipalpis, três capturadas 
no peridomicilio do lote 20 e uma na gruta próxima do lote 56 , não foi possível determinar, pelo seqüenciamento, a espécie de Leishmania.

O encontro de Leishmania (Viannia) nas amostras de cães e flebotomineos será avaliado pelo uso de sonda com G6PD, para discriminar se o parasita é Leishmania (Viannia) braziliensis ou outra espécie deste subgênero. 


\section{DISCUSSÃO}

Os resultados obtidos na presente investigação complementam informações sobre a epidemiologia das leishmanioses na área de estudo, inicialmente pesquisada por NUNES (2001), sobretudo em relação aos reservatórios domésticos e aponta para os seus possiveis vetores.

\subsection{Inquérito dos animais domésticos}

Os eqüinos (Equus caballus) têm sido encontrados infectados por Leishmania em áreas de transmissão de leishmaniose tegumentar americana (FALQUETO et al. 1987; AGUILAR et al. 1989; YOSHIDA et al. 1990; FOLLADOR et al. 1999; TOLEZANO 2000). O papel desses animais como possiveis reservatórios domésticos de Leishmania (L.) chagasi, também tem sido pesquisado (CERQUEIRA et al. 1999), em virtude da atração que exercem sobre os flebotomíneos, principalmente, Lutzomyia longipalpis que tem se adaptado ao ambiente doméstico e peridoméstico (XIMENES et al. 1999; PALATNIK-DE-SOUSA et al. 2001; GALATI et al. 2003b).

No presente estudo, como já havia sido observado por NUNES (2001), não foram encontradas evidências clinicas ou sorológicas de infecção natural por Leishmania entre os eqüinos do Assentamento Guaicurus.

Todavia, cabe ressaltar as limitações diagnósticas da reação de imunofluorescência indireta, principalmente na LTA. Assim, a exemplo dos 
resultados obtidos por TOLEZANO (2000) em creme leucocitário de eqüinos, uma nova investigação empregando técnicas moleculares poderia revelar uma outra realidade entre esses animais do Assentamento.

O cão doméstico (Canis familiaris) tem sido considerado um importante reservatório de Leishmania (L.) chagasi em ambiente periurbano e urbano (BARBOSA-DE-DEUS et al. 2002), todavia, o papel deste animal no ciclo de transmissão da leishmaniose tegumentar americana, até o momento, não está esclarecido (REITHINGER e DAVIES 1999).

A soroprevalência canina encontrada, $15,5 \%$ pela reação de imunofluorescência indireta e $31,0 \%$ pelo ensaio imunoenzimático é próxima às observadas nos estados da Bahia, São Paulo e Mato Grosso do Sul sendo de $23,5 \%$, 26,3\% e $24,0 \%$, respectivamente (PARANHOS-SILVA et al. 1996; SANTOS et al. 1998; GALIMBERTTI et al. 1999). Cabe ressaltar que NUNES et al. (2001), na mesma região do presente estudo, relataram soroprevalência de $23,7 \%$.

O quadro clinico foi variável entre os cães reagentes. A maioria apresentava-se aparentemente sadia, porém alguns animais mostraram emagrecimento acentuado, crescimento exagerado de unhas, ulceraçōes, secreçōes oculares, alopecia geral ou localizada, manifestaçōes já verificadas em outros estudos (DEANE 1956; NUNES et al. 1988; GOMES et al. 1996; SANTA ROSA e OLIVEIRA 1997; NUNES et al. 2001).

O ensaio imunoenzimático detectou mais cães soro-reagentes do que a reação de imunofluorescência indireta, fato descrito anteriormente por vários autores (EVANS et al. 1990; PARANHOS-SILVA et al. 1996; 
KANETO 2001; BARBOSA-DE-DEUS et al. 2002). Os resultados obtidos pela PCR no presente projeto reforçaram a maior sensibilidade do EIE em comparação com a RIFI, visto que o EIE reconheceu maior número de cães com infecção comprovada do que a RIFI. Cabe ressaltar que o EIE, também, reconheceu maior número de cães assintomáticos que estavam infectados por Leishmania, do que a RIFI.

O encontro da prevalência de cães reagentes mais elevada nas amostras de soro, tanto pela RIFI $(15,5 \%)$ como no EIE $(31,0 \%)$, quando comparada à dos eluatos sanguíneos (RIFI - 8,5\% e EIE - 18,6\%) está de acordo com as observações de EVANS et al. (1990); ZICKER et al. (1990) e BRAGA et al. (1998).

O nivel de anticorpos detectáveis pelas técnicas sorológicas pode cair e até negativar em cães comprovadamente infectados por Leishmania, cerca de 5 meses ou mais depois da infecção (PARANHOS-SILVA et al. 2003). Este fato, explicaria a ocorrência de 4 cães que haviam sido reagentes na primeira amostra de soro, pelo EIE ou RIFI ou ambas as técnicas e não reagentes na segunda amostra de soro, com PCR positiva, a exemplo do que foi encontrado por REITHINGER et al (2002b).

No presente estudo, os métodos convencionais de demonstração do parasita não foram bem sucedidos, porém as técnicas moleculares permitiram a detecção do DNA de Leishmania e a identificação da espécie envolvida. Dentre os 20 animais com PCR positiva no aspirado de medula óssea, na cultura, em meio acelular, só foi possivel isolar o parasita a partir de baço e fígado de hamsters inoculados com aspirado medular de 10 cães. 
Dessas dez cepas isoladas, somente uma pode ser identificada, em virtude da contaminação ou da dificuldade de manter as promastigotas em quantidade suficiente para a identificação, que ocorreram nas demais cepas. A espécie de Leishmania identificada por anticorpos monoclonais, foi a mesma detectada, pelas técnicas moleculares, na maioria dos cães infectados.

A PCR tem-se mostrado sensível na deteç̧ão de DNA de Leishmania em amostras que foram negativas para o protozoário em cultura (TOLEZANO 2000). Uma das possíveis razões para isto seria a distribuição não homogênea dos parasitas no tecido, freqüentemente presente nos animais com baixa carga parasitária (PARANHOS-SILVA et al. 2003). Em amostras provenientes de áreas endêmicas de leishmaniose tegumentar na Venezuela, demonstrou-se que a PCR foi mais sensivel do que a cultura e o exame dos esfregaços corados, detectando $80 \%$ dos casos comparados aos $42 \%$ e $72 \%$ obtidos, respectivamente (RODRIGUEZ et al. 2002). ASHFORD et al. (1995) sugerem que a PCR poderia servir como um melhor "gold standard" para definir infecção por Leishmania em cães do que a cultura ou inoculação em hamster.

A deteç̧ão do DNA de Leishmania foi maior em amostras de creme leucocitário do que em aspirado de medula óssea, resultado este que diverge do encontrado por outros autores. Em cães de áreas endêmicas de LTA no Peru foram detectadas por PCR taxas de positividade de 8,5 e $9 \%$ em creme leucocitário e 16,7 e $17,4 \%$ em aspirado de medula óssea (REITHINGER et al. 2000, 2003). FISA et al. (2001), em estudo realizado 
em cães de área de leishmaniose visceral na Espanha, demonstrou que o uso de creme leucocitário, obtido do sangue periférico, na realização da PCR foi tão sensivel e específico quanto os aspirados de medula óssea e linfonodo, enfatizando que este tem a vantagem de ser um material menos invasivo para a sua coleta.

A identificação da espécie de Leishmania (Viannia) por meio do seqüenciamento, das amostras de aspirado de medula e creme leucocitário de cães amplificadas por PCR, não foi possível, em virtude da existência de um alto grau de similaridade na seqüência de nucleotídeos do DNA ribossômico entre os organismos do subgênero Viannia. No entanto, considerando-se que os parasitas isolados de casos humanos, na região de estudo, foram identificados como Leishmania (Viannia) braziliensis (NUNES 2001) e que a distribuição geográfica dos demais parasitas desse subgênero associados a casos humanos de LTA está, até o momento, restrita à região norte do território nacional e sem relatos de infecção canina (DEDET 1993; SILVEIRA et al. 2002), existe forte indicação de que os cães pesquisados estavam infectados por essa espécie de Leishmania.

No Peru, foram identificados dois cães naturalmente infectados por Leishmania (Viannia) spp, sendo que o parasita foi detectado a partir de material colhido de conjuntiva, pulmão, linfonodo, ovários e sangue (REITHINGER et al 2002a). Em áreas peruanas, onde L. (V.) braziliensis e L. (V.) peruviana são endêmicas, infecção natural por Leishmania (Viannia) em cães tem sido detectada em amostras de sangue total, creme leucocitário e aspirado de medula óssea (REITHINGER et al 2000). 
A infecção natural por Leishmania (V.) braziliensis em cães, causando lesões no tegumento, tem sido descrita no Brasil (BARRETTO et al. 1984; FALQUETO et al. 1986; YOSHIDA et al. 1990; LONARDONI et al. 1993; VASCONCELOS et al. 1994; MADEIRA et al. 2003) e sua visceralização, já foi detectada em linfonodo de um cão no Rio de Janeiro (MARZOCHI et al. 1983). Assim, se confirmada a presença da L. (V.) brazilensis em cães no Guaicurus, amplia-se o relato da infecção por este parasita em cães brasileiros.

O presente encontro de Leishmania (L.) amazonensis em aspirado de medula óssea e creme leucocitário dos cães foi surpreendente, visto que esta espécie só foi relatada, recentemente, no Estado do Mato Grosso do Sul em seis casos humanos de LTA no municipio de Bela Vista (DORVAL et al. 2002). No entanto, a presença desse protozoário em aspirado de linfonodo já foi observada em dois cães no Estado de São Paulo (TOLEZANO 2000) e em casos humanos de leishmaniose visceral, na Bahia, nos quais o parasita foi isolado de aspirado de medula óssea (BARRAL et al. 1991).

A presente detecção de DNA de leishmânias dermatotrópicas no sangue periférico (creme leucocitário) de cães indica a possibilidade deste animal participar da cadeia de transmissão da LTA, atuando como fonte de infecção para a fêmea do flebotomíneo, quando do repasto sanguíneo, como tem sido proposto por REITHINGER et al. (2000). A alta prevalência de Leishmania (Viannia) em amostras de sangue e de medula óssea de cães assintomáticos e sintomáticos de área endêmica de $L$. (V.) braziliensis 
e L. (V.) peruviana, no Peru, tem fornecido adicional evidência do provável papel deste animal como reservatório de LTA (REITHINGER et al. 2000; REITHINGER e DAVIES 2002).

Nunes (2001) diagnosticou 7 casos humanos de LTA por L. (V.) braziliensis em moradores do Assentamento e concluiu que o provável local de infecção era em áreas de mata externas ao Assentamento. Todavia, no presente projeto, a detecção de Leishmania (Viannia) sp, provavelmente $L$. (V.) braziliensis e Leishmania (L.) amazonensis em cães domésticos e flebotomíneos, aponta para a possibilidade de transmissão destes dois agentes à população humana, do Assentamento Guaicurus. Salienta-se a importância do diagnóstico específico do parasita, uma vez que L. (L.) amazonensis está associada aos casos cutâneos difusos da doença (LAINSON e SHAW 1987).

O encontro de um cão co-infectado por Leishmania (L.) chagasi e Trypanosoma evansi demonstra a presença deste outro tripanossomatídeo no Assentamento Guaicurus, como já assinalada em outras áreas sul-matogrossenses (STEVENS et al. 1989; NUNES 1996). Tendo-se em vista que reações cruzadas podem ocorrer entre esses dois parasitas na sorologia, é possivel que entre os cães reagentes, dos quais não foi possivel colher material para tentativa de isolamento e/ou detecção de DNA do parasita, alguns poderiam estar infectados apenas pelo Trypanosoma evansi. Neste caso, a taxa de soroprevalência da leishmaniose encontrada estaria superestimada. 
Entre os 19 cães encontrados com infecção natural por $L$. (L.) chagasi, 8 apresentavam-se assintomáticos, 6 oligossintomáticos e 5 polissintomáticos. Estudos sobre a infectividade dos cães para os flebotomíneos têm demonstrado que animais polissintomáticos são mais infectivos para o vetor, enquanto que cães assintomáticos representam uma fonte modesta de L. (L.) chagasi (SHERLOCK 1996; TRAVI et al. 2001). COURTENAY et al (2002) observaram que somente $43 \%$ dos cães infectados por Leishmania (L.) chagasi podem infectar os flebotomineos e que não há relação entre a proporção de flebotomíneos infectados e o quadro clínico do cão.

Embora um cão tenha se mostrado menos atrativo à Lutzomyia longipalpis do que um cavalo, em estudo com iscas animais realizado no Assentamento Guaicurus (GALATI et al. 2003b), a presença de um maior número de cães em relação ao de eqüinos, sobretudo no peridomicilio, onde a freqüência deste flebotomíneo tem sido registrada com maior intensidade (GALATI et al. 2003b), aliada ao hábito alimentar oportunista deste inseto (MORRISON et al. 1993), poderia levá-lo a se alimentar mais intensamente no cão, o que explicaria as elevadas taxas de prevalência da infecção canina encontradas no local.

Dentre os fatores que levaram ao estabelecimento da transmissão de leishmaniose visceral entre a população canina do Assentamento Guaicurus, discutidos por NUNES (2001), destacam-se as modificações ambientais provocadas pela ação predatória humana, principalmente pelos desmatamentos; dispersão, em virtude dessas alterações ambientais, do 
reservatório natural do parasita, possivelmente, o lobo Cerdocyon thous animal abundante na região e que já foi encontrado naturalmente infectado por L. (L.) chagasi na Amazônia (LAINSON et al. 1969; SILVEIRA et al. 1982) e no Mato Grosso do Sul (MELLO et al. 1988); introdução de cães doentes, provenientes de outras cidades do Estado onde ocorre a parasitose, devido às migraçōes de trabalhadores rurais; construção das casas e seus anexos próximos às encostas e pés-de-serra, facilitando o contato dos vetores com os animais domésticos; falta de limpeza nos peridomícilios e em seus anexos propiciando ecótopos favoráveis à proliferação do vetor.

Ainda não foram relatados casos humanos de leishmaniose visceral no Assentamento Guaicurus ${ }^{1}$ (NUNES 2001), quadro este semelhante ao observado por PARANHOS-SILVA et al. (1996), que relataram a ausência de casos humanos de LVA em alguns locais com alta soroprevalência de leishmaniose canina. Por outro lado, CUNHA et al. (1995) encontraram soroprevalência canina de $6,3 \%$ e observaram uma possivel associação entre a infecção humana e a presença de cães dentro ou próximo da residência. Cabe salientar ainda, que em algumas áreas endêmicas a infecção canina precedeu os casos humanos da doença (SHERLOCK 1996; GALIMBERTI et al. 1999).

Apesar da ausência de casos de LVA no Assentamento Guaicurus, a elevada taxa de prevalência da infecção canina e altas densidades de populações de flebotomíneos potencialmente vetores em ambiente peri e intradomiciliar, como se verá mais adiante, parecem apontar para a 
possibilidade de infecção por L. (L.) chagasi na população humana local. Embora, estudo de soroprevalência venha sendo desenvolvido nesta população ${ }^{1}$, há que se atentar para o emprego de técnicas moleculares ou isolamento dos parasitas para a identificação dos mesmos, uma vez que foram três as espécies de Leishmania encontradas na área.

\subsection{Inquérito sobre a fauna flebotominea}

A identificação das espécies de flebotomineos que ocorrem em uma área endêmica de leishmaniose, das taxas de infecção por Leishmania e das espécies do parasita, auxiliam a compreender a epidemiologia da doença e a propor medidas para a sua prevenção e controle (ARANSAY et al. 2000; MICHALSKY et al. 2002).

A fauna flebotomínea encontrada no presente estudo foi muito parecida à descrita anteriormente para a região (NUNES 2001; GALATI et al. 2003a, 2003b), acrescida apenas de Lutzomyia dispar, da qual se capturou apenas um exemplar (tabela 11).

Entre os flebotomíneos capturados no periodo de outubro de 2002 a outubro de 2003, em armadilhas automáticas luminosas com e sem inseticida e armadilha de Shannon, no Assentamento Guaicurus, foi nítido o predomínio de Lutzomyia longipalpis (72,4\%). A segunda espécie mais freqüente foi Lutzomyia almerioi $(20,2 \%)$. Ambas responderam por cerca de $93,0 \%$ dos espécimes capturados. Nyssomia whitmani $(2,8 \%)$ foi a terceira

\footnotetext{
${ }^{1}$ NUNES VLB. Comunicação pessoal. Campo Grande, UNIDERP, 2004.

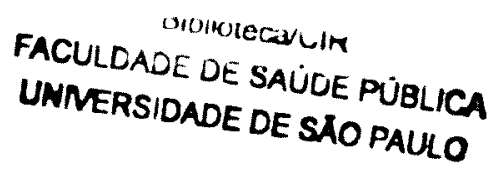


espécie que apresentou maior freqüência, porém bem distante das anteriores (tabela 11).

Quanto a sazonalidade, observou-se que as freqüencias mais elevadas foram nos meses de fevereiro e junho de 2003. Observando-se as médias geométricas de Williams no total de ecótopos estudados com armadilhas automáticas luminosas (tabela 15 e figura 22) percebe-se que Lu. longipalpis predominou no verão, quando ocorreram dois picos (dezembro/02 e fevereiro/03) e no inverno (julho de 2003). Lu. almerioi apresentou o mesmo comportamento, porém com pico bem mais discreto no inverno, ao contrário de Lu. longipalpis e $\mathrm{Ny}$. whitmani, em todos os meses a média de fêmeas de $L u$ almerioi foi maior que a de machos. $N y$. whitmani foi freqüente no verão, porém predominou no inverno de 2003 , chegando a "desaparecer" nos meses de maio e outubro do mesmo ano. 0 comportamento dessas três espécies assemelha-se ao já observado no Assentamento Guaicurus e outras áreas da Serra da Bodoquena (NUNES 2001; GALATI et al. 2003a, 2003b).

A maior diversidade das espécies (tabela 13) foi encontrada na mata do lote $19(2,2)$ e do lote $20(1,8)$, o que era esperado visto que as espécies de flebotomineos são primitivamente de ambientes florestais. No peridomicilio dos lotes 19 e 20 foram encontradas, 10 e 8 espécies, respectivamente, sendo que no mesmo ambiente em outros lotes 3 a 7 espécies foram observadas. A menor diversidade das espécies foi encontrada no intradomícilio, a exemplo do que foi encontrado por MIRANDA et al. (2002). 
Nas capturas realizadas quinzenalmente em CDC com inseticida (tabela 13), observou-se que além das três espécies mais freqüentes descritas anteriormente, foram encontradas nos intradomicilios amostrados, em baixissimas densidades, ou seja, na maioria das vezes um espécime, $B$. cunhai, B. brumpti, E. corumbaensis, P. shannoni, P. punctigeniculata, $M$. peresi, P. kuscheli, S. sordellii, o mesmo ocorreu no peridomicílio, onde além destes, dois espécimes de $M$. oliveirai e um de $B$. avellari foram observados. O encontro de espécies mais associadas ao ambiente florestal, em número bastante reduzido, em ambientes que sofreram a ação antrópica, deve-se provavelmente ao fato desses ambientes estarem muito próximos das matas, o que freqüentemente ocorre no Assentamento Guaicurus.

As taxas de infecção natural por Leishmania em fêmeas de flebotomíneos encontradas em áreas endêmicas de LTA, geralmente, são baixas, como as observadas no Brasil, nos Estados do Ceará, 0,8\% e 0,32\% (AZEVEDO e RANGEL 1991; QUEIROZ et al. 1994), Bahia, 0,4\% e 0,52\% (RYAN et al. 1990; MIRANDA et al. 2002), Mato Grosso do Sul, 0,15\% (GALATI et al. 1996), São Paulo, no início da década de $40,0,24 \%$ (PESSOA e COUTINHO 1941) e mais recente, 0,22\% (CASANOVA et al. 1995), Minas Gerais, 0,13\% (RANGEL et al. 1985), Paraná, 0,15\% (LUZ et al. 2000) e Rio Grande do Sul, 0,33\% (SILVA e GRUNEWALD 1999).

O mesmo fato tem ocorrido em outros países americanos, onde taxas de $0,06 \%$ e $0,14 \%$ (PEREZ et al. 1991, 1994) foram obtidas no Peru, $0,16 \%$ no Paraguai (HASHIGUCHI et al. 1992) e na Venezuela $0,19 \%$ no 
Estado de Carabobo (RODRIGUEZ et al. 1999) e 1,09\% no Estado de Miranda (FELICIANGELI et al. 1994).

As taxas de infecção por Leishmania, conforme a espécie de flebotomineo encontrada naturalmente infectada, em algumas dessas áreas endêmicas de LTA variaram como as descritas na Venezuela, 1,19\% em Lu. ovallesi, 0,47 e $0,29 \%$ em Lu. gomezi, 0,43\% em Lu. panamensis (FELICIANGELI et al. 1994; RODRIGUEZ et al. 1999); no Peru, 0,16\% em Lu. peruensis e 0,13\% em Lu. verrucarum (PEREZ et al. 1994); no Paraguai, $0,38 \%$ em Ny. whitmani (HASHIGUCHI et al. 1992) e no Brasil, 0,47\% em Ny. whitmani e 0,06\% em Lu. migonei no Estado do Ceará (QUEIROZ et al. 1994), $0,6 \%$ em Lu. pessoai e $0,8 \%$ em Lu. misionensis no Rio Grande do Sul (SILVA e GRUNEWALD 1999) e 0,24\% em Ny. neivai em São Paulo (CASANOVA et al. 1995).

Em áreas endêmicas de leishmaniose visceral americana, taxas de infecção natural por Leishmania obtidas em flebotomíneos foram de 0,59\% na Colômbia (CORREDOR 1989), 0,15\% em Pintomyia (Pifanomyia) evansi e $0,28 \%$ em Lu. longipalpis na Venezuela (FELICIANGELI et al. 1999), 0,2\% no Estado da Bahia (SHERLOCK 1996), 0,39\% no Estado do Mato Grosso do Sul (SANTOS et al. 1998) e 7,14\% no Estado do Pará, Brasil (LAINSON et al. 1985).

No presente estudo, a taxa de Infecção natural por flagelados encontrada em fêmeas de flebotomíneos pela dissecção, 0,22\% (tabela 20), assemelha-se àquelas anteriormente descritas para áreas endêmicas de leishmanioses no Brasil, no entanto com o emprego de técnicas moleculares 
a taxa de infecção por Leishmania elevou-se para 1,23\% (tabela 22), em virtude da alta sensibilidade da PCR que possibilitou a detecção do parasita, ou pelo menos do seu DNA, no flebotomíneo. Acresce que esta taxa pode ainda estar subestimada, uma vez que em oito "pools" positivos, haviam de 2 a 7 fêmeas, tendo sido considerado como sendo somente uma fêmea positiva.

Ao comparar as taxas de infecção encontradas pela PCR (tabelas 21 e 22), por local de captura das fêmeas, observa-se que taxas muito próximas ocorreram no lote $19(1,32 \%$ - 4/303) e lote $20(1,27 \%$ - 9/708) e na gruta situada próximo ao lote 56 foi menos que a metade $(0,51 \%)$ das anteriores. As altíssimas taxas encontradas no lote 2, na mata do lote 19 , bem como em Lutzomyia longipalpis no intradomicílo do lote 20 e da gruta, sofreram influência do número muito reduzido de fêmeas investigadas.

Lutzomyia longipalpis é a principal espécie vetora de Leishmania (L.) chagasi na América (LAINSON et al. 1985; DEDET 1993; SHERLOCK 1994), com algumas exceções, tais como: em focos de leishmaniose visceral, na Colômbia, onde se atribui, também, a Pintomyia (Pifanomyia) evansi (Nuñez-Tóvar, 1924) a transmissão da doença (TRAVI et al. 1996) e na Venezuela, onde se detectou a infecção natural desta espécie por L. (L.) chagasi (FELICIANGELI et al. 1999). Já, em duas cidades do Mato Grosso do Sul, suspeita-se que Lutzomyia cruzi atue na transmissão, por evidência epidemiológica (GALATI et al. 1997) e pelo encontro de infecção natural neste flebotomineo pela L. (L.) chagasi (SANTOS et al. 1998). 
No presente trabalho observou-se, por métodos moleculares, que a taxa de infecção por Leishmania em Lu. longipalpis foi alta $(2,76 \%)$, sendo sete vezes maior aquela obtida por SANTOS et al. (1998) para Lu. cruzi, em área de transmissão de LVA no Estado de Mato Grosso do Sul.

Além de L. (L.) chagasi $(0,3 \%)$, Lu. longipalpis também foi encontrada infectada naturalmente por $L$. (L.) amazonensis $(1,0 \%)$ e $L$. (Viannia) sp $(0,5 \%)$, espécies associadas a LTA. Esse encontro é corroborado com estudos de infecção experimental em fêmeas de Lutzomyia longipalpis, nos quais se demonstrou que estas se infectam com Leishmania (L.) amazonensis $(37 \%)$, L. (L.) chagasi $(13 \%)$ e L. (V.) braziliensis (9\%) (DA SILVA et al. 1990). A capacidade de Lu. longipalpis transmitir L. (L.) amazonensis para hamsters foi demonstrada por SHERLOCK (1996), sugerindo que também possa transmitir este parasita para outros hospedeiros vertebrados, inclusive para a população canina.

O predomínio de Lutzomyia longipalpis no peridomicilio e a elevada taxa de infecção natural por Leishmania encontrada, $4,35 \%$ no peridomicilio do lote 20 e 1,24\% no peridomicílio do lote 19, ou seja, cerca de onze vezes e três vezes mais elevadas, respectivamente, que a taxa obtida por SANTOS et al. (1998), parece ser um forte indicativo de que esta espécie possa estar transmitindo os parasitas entre a população canina do Assentamento Guaicurus.

A impossibilidade no presente estudo de caracterizar quatro "pools" de Lutzomyia longipalpis, provenientes do peridomicilio do lote 20 e da gruta, aponta para a necessidade de repetição do seqüenciamento, após 
nova purificação do produto de PCR, bem como a utilização de sonda G6PD para discriminar L. (V.) braziliensis dentre os outros organismos do subgênero Viannia encontrados em amostras caninas e em fêmeas de flebotomineos.

Nyssomyia whitmani é uma espécie antropofilica, que atua como vetora de LTA no Brasil e no Paraguai (AGUIAR et al. 1989; AZEVEDO e RANGEL 1991; GOMES 1992; HASHIGUCHI et al. 1992; GALATI et al. 1996; LUZ et al. 2000; MIRANDA et al. 2002). No presente estudo não foi observada infecção natural nesta espécie, provavelmente, pelo pequeno número de fêmeas pesquisadas (13 espécimes), apesar de que VEXENAT et al. (1986) também não encontraram a infecção entre 1832 fêmeas pesquisadas, em área endêmica de LTA, onde Ny. whitmani parece atuar como vetora. De acordo com a taxa de infecção natural obtida por GALATI et al. (1996), em Ny. whitmani $(0,16 \%)$ em outra área do Estado de Mato Grosso do Sul, seria necessário pesquisar cerca de 625 fêmeas para encontrar uma infectada.

Lutzomyia almerioi pertence ao mesmo grupo monofilético de $L u$. longipalpis, Lu. cruzi e Lu. forattinii, esta última, também com suspeitas de transmitir a LVA no Estado do Mato Grosso do Sul (GALATI et al. 1997). Essa espécie tem apresentado elevada densidade populacional, em cavernas da Província Espeleológica da Bodoquena (GALATI et al. 2003a), onde existem mamiferos silvestres (COSTA e SEGOND 1992) que podem atuar como reservatórios de Leishmania naquela região. É uma espécie altamente antropofilica, com atividade noturna e diurna e foi observada com 
infecção natural por flagelados na fazenda Pitangueiras, municipio de Bonito, MS (GALATI et al. 1999; NUNES 2001).

Nos últimos anos, têm-se observado a intensificação do ecoturismo para a região sudoeste do Estado de Mato Grosso do Sul, principalmente, para as áreas de cavernas e de rios que cortam o Planalto da Bodoquena, assim, torna-se importante um planejamento cuidadoso dessas atividades para a região (GALATI et al. 1999, 2003a).

No presente trabalho, foram encontrados no lote 20 , três espécimes de Lu. almerioi, observados ao microscópio, infectados naturalmente por flagelados, um deles capturado dentro de casa $(1,27 \%$ e $1,37 \%$ por PCR) em dormitório e outros dois no peridomicilio $(0,42 \%$ e $0,43 \%$ por PCR), um capturado em horário noturno e o outro pela manhã. A caracterização molecular do DNA do parasita de duas dessas fêmeas e de uma capturada na mata do lote 19, demonstrou tratar-se de Leishmania (L.) chagasi $(0,37 \%)$. Uma das fêmeas de Lu. almerioi infectada por flagelados, capturada no peridomicilio do lote 20 , foi negativa na PCR, isto pode ter sido por haver pouquíssimos parasitas, os quais não foram detectados ou então, a infecção ser por outro flagelado e não Leishmania, a exemplo do que foi encontrado por RODRIGUEZ et al. (1999), que entre 65 fêmeas observadas com flagelados, somente 5 tinham infecção por Leishmania.

Além de L. (L.) chagasi, detectou-se, por técnicas moleculares, uma fêmea de Lu. almerioi com infecção natural por Leishmania (Viannia) sp $(0,12 \%)$, provavelmente Leishmania $(V$.$) braziliensis agente associado, até o$ 
momento, a maioria dos casos de LTA que ocorrem no Estado de Mato Grosso do Sul.

O presente estudo constitui-se no primeiro relato de infecção natural confirmada de Lu. almerioi por L. (L.) chagasi e L. (Viannia) sp, esses achados colaboram com a possibilidade desta espécie, também, atuar como vetora de leishmanioses naquela região. A ocorrência, no ano de 2002, de um caso de LTA em um morador do lote $20^{1}$, reforça a suspeita da participação de Lu. almerioi na transmissão dessa doença em Guaicurus, pois neste lote fêmeas deste flebotomíneo (tabelas 20 e 21) foram capturadas com freqüência elevada no peri (475 espécimes) e intradomicilio (79 espécimes).

A deteç̧ão de DNA de Leishmania não conclui que uma espécie de flebotomineo seja vetora, desde que não é possível distinguir pela PCR entre a presença de amastigotas de Leishmania provenientes de um repasto sanguíneo em animal infectado, da forma promastigota, que se desenvolve no intestino do vetor e é infectante para o hospedeiro (ARANSAY et al. 2000). Acresce que para um flebotomíneo atuar como vetor dependerá de sua capacidade de manter o desenvolvimento do parasita e de transmiti-lo (KILLICK-KENDRICK 1990). Portanto, esses aspectos ainda necessitam ser demonstrados para indicar $L$. almerioi como vetora das leishmânias nela encontradas.

MIRANDA et al. (2002) demonstrou que há heterogeneidade na distribuição espacial de flebotomíneos infectados em uma área endêmica de

\footnotetext{
' NUNES VLB. Comunicação pessoal. Campo Grande, UNIDERP, 2004.
} 
LTA na Bahia. No presente trabalho, o fato da maior densidade de flebotomineos ter sido encontrada ( $86 \%$ dos espécimes capturados) nos lotes 19 e 20 e a maioria das fêmeas infectadas pela Leishmania serem provenientes destes dois sitios de captura, são aspectos sugestivos de que esta área, a noroeste do Assentamento, oferece maior risco de transmissão de leishmanioses. Todavia, há que se ter presente, que o número de fêmeas investigadas para a infecção natural por Leishmania foi bem mais reduzido nos demais pontos, em virtude das capturas pouco rendosas. 


\section{CONCLUSÕES}

No presente estudo, não foram encontradas evidências clínicas e nem sorológicas de infecção natural por Leishmania entre os eqüinos (Equus caballus) do Assentamento Guaicurus.

A prevalência de anticorpos anti-Leishmania encontrada nas amostras de soro dos cães do Assentamento Guaicurus foi de $15,5 \%$ pela reação de imunofluorescência indireta e $31,0 \%$ pelo ensaio imunoenzimático.

O ensaio imunoenzimático detectou mais cães reagentes do que a reação de imunofluorescência indireta, sendo que a prevalência de anticorpos foi mais elevada nas amostras de soro, quase o dobro, do que nos eluatos sanguineos, em ambas as técnicas.

As técnicas moleculares permitiram a deteç̧ão do DNA de Leishmania em amostras de creme leucocitário e aspirado de medula óssea de cães do Assentamento Guaicurus, sendo encontrado animais infectados por Leishmania (L.) chagasi, Leishmania (Viannia) sp e Leishmania (L.) amazonensis. 
A fauna flebotomínea encontrada nos vários ambientes do Assentamento Guaicurus, tais como gruta, mata, peri e intradomicilio foi semelhante, provavelmente pela proximidade desses ambientes.

Observou-se nítido predominio de Lu. longipalpis $(72,4 \%)$, seguida por Lutzomyia almerioi $(20,2 \%)$ e Nyssomia whitmani $(2,8 \%)$ em todos os ambientes.

A maior diversidade de espécies de flebotomíneos foi encontrada nas matas.

O maior número de espécimes foi capturado nos meses de fevereiro de 2003 e junho de 2003. Lu. longipalpis, Lu. almerioi e Ny. whitmani predominaram no verão. Lu. longipalpis e Ny. whitmani também apresentaram pico no inverno.

A taxa de Infecção natural por flagelados encontrada em fêmeas de flebotomíneos pela dissecção, $0,22 \%$, foi cerca de seis vezes menor a obtida pelo emprego de técnicas moleculares $(1,23 \%)$.

A maior taxa de infecção ocorreu no lote $19(1,32 \%)$, seguido pelo lote $20(1,27 \%)$ e pela gruta $(0,51 \%)$ próxima ao lote 56 . 
Lutzomyia longipalpis foi encontrada infectada naturalmente, por métodos moleculares, por L. (L.) chagasi, L. (L.) amazonensis e L. (Viannia), estas duas últimas associadas a LTA.

O predominio de Lutzomyia longipalpis no peridomicilio e a elevada taxa de infecção encontrada $(2,76 \%)$ indicam que esta espécie possa estar transmitindo os parasitas entre a população canina do Assentamento Guaicurus.

Identificou-se, pela primeira vez, a infecção natural de Lu. almerioi por L. (L.) chagasi e L. (Viannia) sp, o que sugere a possibilidade desta espécie, também, atuar como vetora de leishmanioses na região.

Observou-se ampla distribuição espacial dos flebotomíneos pelo Assentamento Guaicurus, porém em alguns locais com densidades bem reduzidas. A maior densidade foi encontrada nos lotes 19 e 20 , bem como a maioria das fêmeas infectadas pela Leishmania.

A deteç̧ão de Leishmania (L.) chagasi, Leishmania (Viannia) sp e Leishmania (L.) amazonensis em cães domésticos e flebotomíneos aponta para a possibilidade de ocorrência também da infecção humana por esses agentes no Assentamento Guaicurus. A proximidade dos diversos ambientes amostrados dificultou a identificação dos prováveis locais de transmissão das leishmanioses. 


\section{REFERÊNCIAS BIBLIOGRÁFICAS}

Aguilar CM, Fernandez E, Fernandez R, Deane LM. Study of an outbreak of cutaneous leishmaniasis in Venezuela: the role of domestic animals. Mem Inst Oswaldo Cruz 1984; 79: 181-95.

Aguilar CM, Rangel EF, Garcia L, Fernandez E, Momen H, Grimaldi Filho G, Vargas Z. Zoonotic cutaneous leishmaniasis due to Leishmania (Viannia) braziliensis associated with domestic animals in Venezuela and Brazil. Mem Inst Oswaldo Cruz 1989; 84: 19-28.

Alvarenga SM, Brasil AE, Del'Arco DM. Geomorfologia. In: Ministério das Minas e Energia Secretaria-Geral. Projeto RADAMBRASIL: levantamento de recursos naturais. Rio de Janeiro: MME; 1982. p. 125-84.

Aransay AM, Scoulica E, Tselentis $Y$. Detection and Identification of Leishmania DNA within Naturally Infected Sand Flies by Seminested PCR on Minicircle Kinetoplastic DNA. Appl Environ Microbiol 2000; 66(5): 1933-38.

Araujo FG, Mayrink W. Fluorescent antibody test in visceral leishmaniasis. IIStudies on the specificity of the test. Rev Inst Med Trop São Paulo 1968; 10: $41-5$. 
Araujo Filho NA, Coura JR, Reis VLL. Leishmaniose tegumentar americana na llha Grande, Rio de Janeiro. III.Reservatórios silvestres e comensais. Rev Soc Bras Med Trop 1981a; 14: 153-61.

Araujo Filho NA, Coura JR, Reis VLL. Leishmaniose tegumentar americana na llha Grande, Rio de Janeiro. IV. Reservatórios domésticos. Rev Soc Bras Med Trop 1981b; 14: 163-9.

Arias JR, Beltrán F, Desjeux P, Walton B. Epidemiología y control de la leishmaniasis en las Américas, por país o territorio. Washington (DC); 1996. (OPAS - Cuaderno Técnico, 44).

Arruda W, Costa FC, Nahas S, Rosenfeld G. Leishmaniose visceral. Bras Méd 1949; 63:64-5.

Ashford DA, Badaró R, Eulalio C, Freire M, Miranda C, Zalis MG, David JR. Studies on the control of visceral leishmaniasis: validation of the Falcon assay screening test-enzyme-linked immunosorbent assay (FAST-ELISA) for field diagnosis of canine visceral leishmaniasis. Am J Trop Med Hyg 1993; 48(1): 1-8. 
Ashford DA, Bozza M, Freire M, Miranda JC, Sherlock I, Eulalio C, Lopes U, Fernandes O, Degrave W, Barker Jr RH, Badaro R, David JR. Comparison of the polymerase chain reaction and serology for the detection of canine visceral leishmaniasis. Am J Trop Med Hyg 1995; 53(3): 251-5.

Ashford RW. The leishmaniases as emerging and reemerging zoonoses. Int J Parasitol 2000; 30: 1269-81.

Azevedo ACR, Rangel EF. A study of sandfly species (DIptera, Psychodidae: Phebotominae) in a focus of cutaneous leishmaniasis in the Municipality of Baturité, Ceará, Brazil. Mem Inst Oswaldo Cruz 1991; 86: 405-10.

Badaró R, Reed SG, Carvalho, EM. Immunofluorescent antibody test in American leishmaniasis: sensitivity and specificity of different morphological forms of two Leishmania species. Am J Trop Med Hyg 1983; 32(3): 480-4.

Badaró R, Jones TC, Lorenço R, Cerf BJ, Sampaio D, Carvalho EM, et al. A prospective study of visceral leishmaniasis in na endemic area of Brazil. J Infect Dis 1986; 154: 639-49.

Badaró R. Current situation for leishmaniasis in Brazil. Proceedings of the International Workshop on control Strategies for Leishmaniasis. Boca Raton, FL: CRC Press, IDRC-CRDI: B 1-5; 1987. 
Barbosa W, Silva RM, Borges PC. Informe preliminar sobre a leishmaniose tegumentar em Goiás. Rev Goiana Med 1965; 11: 1-9.

Barbosa-de-Deus R, Mares-Guia ML, Nunes AZ, Costa KM, Junqueira RG, Mayrink W, Genaro O, Tavares CA. Leishmania major-like antigen for specific and sensitive serodiagnosis of human and canine visceral leishmaniasis. Clin Diagn Lab Immunol 2002; 9(6): 1361-6.

Barbosa-Santos EG, Marzochi MC, Urtado W, Queiros F, Chicarino J, Pacheco RS. Leishmaniasis disseminated by Leishmania braziliensis in a mare (Equus cabalus) immunotherapy and chemotherapy assays. Mem Inst Oswaldo Cruz 1994; 89(2): 217-20.

Barral A, Pedral-Sampaio D, Grimaldi Jr.G, Momen H, McMahon-Pratt D, Ribeiro de Jesus A, Almeida R, Badaró R, Barral-Netto M, Carvalho EM, et al. Leishmaniasis in Bahia, Brazil: evidence that Leishmania amazonensis produces a wide spectrum of clinical disease. Am J Trop Med Hyg 1991; 44(5): 536-46.

Barretto AC, Cuba CC, Vexenat JÁ, Rosa AC, Marsden PD, Magalhāes AV. Características epidemiológicas da leishmaniose tegumentar americana em uma região endêmica do Estado da Bahia. II Leishmaniose canina. Rev Soc Bras Med Trop 1984; 17: 59-65. 
Bittencourt AL, Sodré A, Andrade ZA. Pesquisa de anticorpos circulantes pelo método de imunofluorescência na leishmaniose tegumentar. Rev Inst Med Trop São Paulo 1968; 10: 247-52.

Borges AS, Machado AA, Ferreira MS, Figueiredo JFC, Silva GF, Cimerman S, Bacha HÁ, Teixeira MCL. Concomitâcia de leishmanioses e infecção pelo vírus da imunodeficiência humana (HIV): estudo de quatro casos. Rev Soc Bras Med Trop 1999; 32: 713-9.

Braga MDM, Coelho ICB, Pompeu MML, Evans TG, MacAullife IT, Teixeira MJ, Lima JWO. Controle do calazar canino: comparação dos resultados de um programa de eliminação rápida de cães sororeagentes por imunoenzimático com outro de eliminação tardia de cães sororeagentes por teste de imunofluorescência indireta de eluato de papel filtro. Rev Soc Bras Med Trop 1998; 31(5): 419-24.

Brandão-Filho SP, Brito ME, Carvalho FG, Ishikawa EA, Cupolillo E, FloeterWinter L, Shaw JJ. Wild and synanthropic hosts of Leishmania (Viannia) braziliensis in the endemic cutaneous leishmaniasis locality of Amaraji, Pernambuco State, Brazil. Trans R Soc Trop Med Hyg 2003; 97(3): 291-6.

Bray RS, Lainson R. The immunology and serology of leishmaniasis. I. The fluorescent antibody staining technique. Trans R Soc Trop Med Hyg 1965; 59: 535- 44. 
Cabrera OL, Munsterman LE, Cardenas R, Gutierrez R, Ferro C. Definición de las condiciones de temperatura y almacenamiento adecuadas en la detección de ADN de Leishmania por PCR en flebotominos. Biomédica 2002; 22: 296-302.

Camargo ME, Rebonato C. Cross - reactivity in fluorescence tests for Trypanosoma and Leishmania antibodies. Am J Trop Med Hyg 1969; 18: 500-5.

Casanova C, Mayo RC, Rangel O, Mascarini LM, Pignatti MG, Galati EAB, Gomes AC. Natural Lutzomyia intermedia (Lutz \& Neiva, 1912) infection in the Valley of Mogi Gauçu River, State of São Paulo, Brazil. Bol Dir Malariol San Amb 1995; 35 Suppl 1: 77-84.

Castilho TM, Shaw JJ, Floeter-Winter LM. New PCR assay using glucose-6phosphate dehydrogenase for identification of Leishmania species. J Clin Microbiol 2003; 41(2): 540-46.

Cerqueira EJL, Sherlock IA, Nakatami M, Badaró R. Dados preliminares sobre o papel dos eqüídeos na ecologia da leishmaniose visceral. Rev Soc Bras Med Trop 1999; 32 Suppl 1: 228.

Chagas E, Chagas AW. Notas sobre epidemiologia da leishmaniose visceral americana em Mato Grosso. Hospital 1938; 13: 471-80. 
Chiari CA, Mayrink W, Magalhães PA. Reação de imunofluorescência indireta no controle de tratamento da leishmaniose tegumentar americana. Rev Inst Med Trop São Paulo 1973; 15: 298-303.

Corredor A, Gallego JF, Tesh RB, Morales A, De Carrasquilla CF, Young DG, Kreutzer RD, Boshell J, Palau MT, Caceres E, Pelaez D. Epidemiology of visceral leishmaniasis in Colômbia. Am J Trop Med Hyg 1989; 40(5): 480-6.

Costa CHN, Gomes RBB, Silva MRB, Garcez LM, Ramos PKS, Santos RS, Shaw JJ, David JR, Maguire JH. Competence of the human host as a reservoir for Leishmania chagasi. J Infect Dis 2000; 182: 997-1000.

Costa NMC, Second CR. Plano de manejo ecológico como forma de gestão de unidades de conservação - Bodoquena: um estudo de caso. Rev Bras Geogr 1992; 54: 5-26.

Courtenay O, Quinnell RJ, Garcez LM, Shaw JJ, Dye C. Infectiousness in a cohort of Brazilian dogs: why culling fails to control visceral leishmaniasis in areas of high transmission. J Infect Dis 2002; 186: 1314-20.

Coutinho SG, Marzochi MCA, Souza WJS, Amendoeira MRR. Leishmaniose tegumentar americana. J Bras Med 1981; 41: 104-18. 
Coutinho SG, Nunes MP, Marzochi MCA, Tramontano N. A survey for American cutaneous and visceral leishmaniasis among 1342 dogs from areas in Rio de Janeiro (Brazil) where the human diseases occur. Mem Inst Oswaldo Cruz 1985; 80: 17-22.

Cunha S, Freire M, Eulalio C, Cristovão J, Netto E, Johnson. WD Jr, Reed SG, Badaro R. Visceral leishmaniasis in a new ecological niche near a major metropolitan area of Brazil. Trans R Soc Trop Med Hyg 1995; 89(2): 155-8.

Da Silva AL, Williams P, Melo MN, Mayrink W. Susceptibility of laboratoryreared female Lutzomyia longipalpis (Lutz \& Neiva, 1912) to infection by different species and strains of Leishmania (Ross, 1903). Mem Inst Oswaldo Cruz 1990; 85(4): 453-8.

Deane LM. Leishmaniose visceral no Brasil. Estudos sobre reservatórios e transmissores realizados no Estado do Ceará. São Paulo; 1956. [Tese de Livre-Docência - Universidade de São Paulo].

Dedet JP. Leishmania et leishmanioses du continent américan. Anna Inst Pasteur actualités 1993; 4(1): 3-25.

Dias ES, Falcão AL, Silva JE. Notes on the sand fly (Diptera: Psychodidae) in the State of Rio Grande do Sul. Mem Inst Oswaldo Cruz 1997; 92(3): 329-32. 
Dias M, Mayrink W, Deane LM, Costa CA, Magalhães PA, Melo MN, Batista SM, Araujo FG, Coelho MV, Williams P. Epidemiologia da leishmaniose tegumentar americana. I - Estudo de reservatórios em área endêmica no Estado de Minas Gerais. Rev Inst Med Trop São Paulo 1977; 19: 403-10.

Dorval MEC, Oshiro ET, Cupollilo E, Castro ACC. Primeiro relato da ocorrência de Leishmania amazonensis no Estado de Mato Grosso do Sul, Brasil. Rev Soc Bras Med Trop 2002; 35 Suppl 3: 220.

Duxbury RE, Sadun EH. Fluorescent antibody test for the serodiagnosis of visceral leishmaniasis. Am J Trop Med Hyg 1964; 13: 525-9.

Evans TG, Vasconcelos IAB, Lima JW, Teixeira JM, McAullife IT, Lopes UG, Pearson RD, Vasconcelos AW. Canine visceral leishmaniasis in northeast Brazil: assessment of serodiagnostic methods. Am J Trop Med Hyg 1990; 42(2):118-23.

Falqueto A, Coura JR, Barros GC, Grimaldi Jr. G, Sessa PA, Carias VRD, Jesus AC, Alencar JTA. Participação do cão no ciclo de transmissão da leishmaniose tegumentar no Município de Viana, Estado do Espirito Santo, Brasil. Mem Inst Oswaldo Cruz 1986; 81: 155-63. 
Falqueto A, Varejao JB, Sessa PA. Cutaneous leishmaniasis in a horse (Equus caballus) from endemic área in the state of Espirito Santo, Brazil. Mem Inst Oswaldo Cruz 1987; 82(3): 443.

Feliciangeli MD, Rodriguez N, Bravo A, Arias F, Guzman B. Vectors of cutaneous leishmaniasis in north-central Venezuela. Med Vet Entomol 1994; 8(4): 317-24.

Feliciangeli MD, Rodriguez N, De Guglielmo Z, Rodriguez A. The reemergence of American visceral leishmaniasis in an old focus in Venezuela. II. Vectors and parasites. Parasite 1999; 6(2): 113-20.

Ferreira E, Lucena S, Fonseca G, Barbosa TC, Aquino RB, Lambert JS, Nogueira AS. Visceral leishmaniasis in a Brazilian child infected perinatally with human immunodeficiency virus. Pediatr Infect Dis J 2001; 20(2): 224-6.

Ferreira MS. A sindrome da imunodeficiência adquirida e as doenças endêmicas no Brasil. Rev Soc Bras Med Trop 1996; 29: 531-5.

Ferro C, Morrison AC, Torres M, Pardo R, Wilson ML, Tesh RB. Age structure, blood-feeding behavior, and Leishmania chagasi infection in Lutzomya longipalpis (Diptera: Psychodidae) at an endemic focua of visceral leishmanisis in Colombia. J Med Entomol 1995; 32(5): 618-29. 
Fisa R, Riera C, Gallego M, Manubens J, Portus M. Nested PCR for diagnosis of canine leishmaniasis in peripheral blood, lymph node and bone marrow aspirates. Vet Parasitol 2001; 99(2): 105-11.

Follador I, Araujo C, Cardoso MA, Tavares-Neto J, Barral A, Miranda JC, Bittencourt A, Carvalho EM. Outbreak of American cutaneous leishmaniasis in Canoa, Santo Amaro, Bahia, Brazil. Rev Soc Bras Med Trop 1999; 32(5): 497-503.

Forattini OP, Pattoli DBG, Rabello EX, Ferreira OA. Infecções naturais de mamiferos silvestres em área endêmica de leishmaniose tegumentar do Estado de São Paulo, Brasil. Rev Saúde Pública 1972; 6: 255-61.

Forattini OP. Entomologia médica. Phlebotominae. Leishmanioses. Bartonelose. $4^{\circ}$ v. São Paulo; Edgard Blücher Ltda; 1973.

Forattini OP, Pattoli DBG, Rabello EX, Ferreira OA. Nota sobre infecção natural de Oryzomys capito laticeps em foco enzoótico de leishmaniose tegumentar do Estado de São Paulo, Brasil. Rev Saúde Pública 1973; 7 : $181-4$.

Furtado T. Critérios para o diagnóstico da leishmaniose tegumentar americana. An Bras Dermatol 1980; 55: 81-6. 
Galati EAB, Rego Jr. F de A, Nunes VLB, Teruya E. Fauna flebotomínica do Município de Corumbá, Mato Grosso do Sul, Brasil e descrição de Lutzomyia forattinii, sp. n. (Diptera, Psychodidae, Phlebotominae). Rev Bras Entomol 1985; 29: 261-6.

Galati EAB, Nunes VLB, Oshiro ET, Rego Jr. F de A. Nova espécie de Phlebotominae, Lutzomyia corumbaensis, sp. n. (Diptera, Psychodidae) do complexo Lutzomyia cortelezzii. Rev Bras Entomol 1989; 33: 465-75.

Galati EAB, Nunes VLB, Dorval MEC, Oshiro ET, Cristaldo G, Espíndola MA, Rocha HC, Garcia WB. Estudo dos flebotomineos (Diptera, Psychodidae), em área de leishmaniose tegumentar, no Estado de Mato Grosso do Sul, Brasil. Rev Saúde Pública 1996; 30: 115-28.

Galati EAB, Nunes VLB, Rego Jr. F de A, Oshiro ET, Chang MR. Estudo dos flebotomíneos (Diptera, Psychodidae), em foco de leishmaniose visceral, no Estado de Mato Grosso do Sul, Brasil. Rev Saúde Pública 1997; 31: 37890.

Galati EAB, Nunes VLB. Descrição de Lutzomyia (Lutzomyia) almerioi (Diptera, Psychodidae, Phlebotominae) do Estado de Mato Grosso do Sul, Brasil. Rev Bras Entomol 1999; 43: 277-85. 
Galati EAB, Nunes VLB, Dorval MEC, Boggiani PC, Shaw JJ, Cristaldo G, Da Rocha HC, Andrade RMG, Casanova C, Naufel G. Ecological aspects of the phlebotomine fauna from Serra da Bodoquena, Mato Grosso do Sul State, Brazil. In: Third International Symposium on Phlebotomine Sandflies; 1999 aug 23 - 27; Montpellier France. Abstracts, p.36.

Galati EAB, Nunes VLB, Dorval MEC, Cristaldo G, Rocha HC, GonçalvesAndrade RM, Naufel G. Attractiveness of Black Shannon Trap for Phlebotomines. Mem Inst Oswaldo Cruz 2001; 96: 641-7.

Galati EAB. Morfologia e Taxonomia. Classificação de Phlebotominae. In: Rangel EF, Lainson R. Flebotomíneos do Brasil. Rio de Janeiro: Fiocruz; 2003.

Galati EAB, Nunes VLB, Boggiani PC, Dorval MEC, Cristaldo G, Da Rocha HC, Oshiro ET, Gonçalves-de-Andrade RM, Naufel G. Phlebotomines (Diptera, Psychodidae) in caves of the Serra da Bodoquena, Mato Grosso do Sul State, Brazil. Rev Bras Entomol 2003a; 47(2): 283-96.

Galati EAB, Nunes VLB, Cristaldo G, Da Rocha HC. Aspectos do comportamento da fauna flebotomínea (Díptera: Psychodidae) em foco de leishmaniose visceral e tegumentar na Serra da Bodoquena e área adjacente, Estado de Mato Grosso do Sul, Brasil. Rev Patol Trop 2003b; $32(2): 235-61$ 
Galimbertti MZ, Katz G, Camargo-Neves VLF, Rodas LAC, Casanova C, Costa Al, Araujo MFL, Taniguchi HH, Barbosa JAR, Barbosa JER, Tolezano JE, Pinto PLS. Leishmaniose visceral americana no Estado de São Paulo. Rev Soc Bras Med Trop 1999; 32 Suppl 1: 217.

Gomes AC, Coutinho SG, Paim GV, Oliveira SMO, Galati EAB, Nunes MP, et al. Aspectos ecológicos da leishmaniose tegumentar americana. 8. Avaliação da atividade enzoótica de Leishmania (Viannia) braziliensis, em ambiente florestal e peridomiciliar, região do Vale do Ribeira, Estado de São Paulo, Brasil. Rev Inst Med Trop São Paulo 1990; 32: 105-15.

Gomes AC. Perfil epidemiológico da leishmaniose tegumentar no Brasil. An Bras Dermatol 1992; 67: 55-60.

Gomes AC. Sand fly vectorial ecology in the State of São Paulo. Mem Inst Oswaldo Cruz 1994; 89: 457-60.

Gomes AC, Silva AR, Costa CHN, Scherlock I, Costa JML, Shaw J, et al. Controle, diagnóstico e tratamento da leishmaniose visceral (Calazar): normas técnicas. Brasilia (DF): Fundação Nacional da Saúde, 1996.

Gomes AC, Costa CHN, Costa JML, Vieira JBF, Lima JWO, Dietze R. Mudanças no controle da leishmaniose visceral no Brasil. Rev Soc Bras Med Trop 2001; 34: 223-28. 
Grimaldi Jr.G, David JR, McMahon-Pratt D. Identification and distribution of New World Leishmania species characterized by serodeme analysis using monoclonal antibodies. Am J Trop Med Hyg 1987; 36: 270-87.

Grimaldi Jr.G, Tesh RB. Leishmaniasis of the New World: current concepts and implications for future research. Clin Microbiol Rev 1993; 6(3): 230-50.

Grisard EC, Steindel M, Shaw JJ, Ishikawa EA, Carvalho-Pinto CJ, EgerMangrich I, Toma HK, Lima JH, Romanha AJ, Campbell DA. Characterization of Leishmania sp strains isolated from autochthonous cases of human cutaneous leishmaniasis in Santa Catarina State, southern Brazil. Acta Trop 2000; 74(1): 89-93.

Guimarães MCS, Giovannini VL, Camargo ME. Antigenic standardization for mucocutaneous leishmaniasis immunofluorescence test. Rev Inst Med Trop São Paulo 1974; 16: 145-8.

Guimarães MCS, Castilho EA, Celeste BJ, Nakahara OS, Netto VA. Almacenamiento a largo plazo de lgG e IgM em papel filtro para su uso em encuestas seroepidemiologicas de enfermedades parasitarias. Bol Of Sanit Panam 1986; 100 (2): 129-43. 
Haddow AJ. Studies on the biting-habits of African mosquitos. An appraisal of methods employed with special reference to the twenty-four catch. Bull Entomol Res 1954; 45: 199-242.

Haddow AJ. Studies on the biting habits and medical importance of East African mosquitoes in the genus Aedes. I- Subgenera Aedimorphus, Banksinella and Nunnius. Bull Entomol Res 1960; 50: 759-79.

Hall TA. BioEdit: a user-friendly biological sequence alignment editor and analysis program for Windows 95/98/NT. Nucleic Acids Symp.Ser. 1999; 41: 95-8.

Handman E. Leishmaniasis: current status of vaccine development. Clin Microbiol Rev 2001; 14: 229-43.

Hashiguchi Y, Chiller T, Inchausti A, De Arias A, Kawabata M, Alexander JB. Phlebotomine sandfly species in Paraguay and their infection with Leishmania. Ann Trop Med Parasitol 1992; 86(2): 175-80.

Herwaldt BL. Leishmaniasis. Lancet 1999; 354: 1191-99.

Herrer A, Christensen HA. Natural cutaneous leishmaniasis among dogs in Panama. Am J Trop Med Hyg 1976; 25: 59-63. 
Iversson LB, Camargo ME, Villanova A, Reichmann MLAB, Andrade EA, Tolezano JE. Inquérito sorológico para pesquisa de leishmaniose visceral em população canina urbana do Município de São Paulo, Brasil (19791982). Rev Inst Med Trop São Paulo 1983; 25: 310-7.

Jacobson RL. Leishmania tropica (Kinetoplastida: Trypanosomatidae) - a perplexing parasite. Folia Parasitol 2003; 50: 241-50.

Kaneto $\mathrm{CN}$. Aspectos da transmissão da leishmaniose visceral no município de Mirandópolis, região noroeste do Estado de São Paulo. São Paulo; 2001. [Tese de Doutorado - Faculdade de Saúde Pública da Universidade de São Paulo].

Killick-Kendrick R. Phlebotomine vectors of the leishmaniasis: a review. Med Vet Entomol 1990; 4(1): 1-24.

Lainson R, Shaw JJ, Lins ZC. Leishmaniasis in Brazil: IV. The fox Cerdocyon thous as a reservoir of Leishmania donovani in Pará State Brazil. Trans $\mathbf{R}$ Soc Trop Med Hyg 1969; 63: 741-5.

Lainson R, Shaw JJ. Leishmaniasis in Brazil: V. Studies on the epidemiology of cutaneous leishmaniasis in Mato Grosso State, and observations on two distinct strains of Leishmania isolated from man and forest animals. Trans R Soc Trop Med Hyg 1970; 64: 654-57. 
Lainson R, Shaw JJ, Ryan L, Ribeiro RSM, Silveira FT. Leishmaniasis in Brazil: XXI. Visceral leishmaniasis in the Amazon Region and further observations on the role of Lutzomyia longipalpis (Lutz \& Neiva, 1912) as the vector. Trans R Soc Trop Med Hyg 1985; 79(2): 223-6.

Lainson R, Shaw JJ. Evolution, classification and geographical distribution. In: Peter W, Killick-Kendrick R, editors. The leishmaniasis in biology and medicine. London: Academic Press; 1987.

Lainson R, Shaw JJ, Silveira FT, Braga RR, Ishikawa EAY. Cutaneous leishmaniasis of man due to Leishmania (Viannia) naiffi Lainson and Shaw, 1989. Ann Parasitol Hum Comp 1990; 65(5-6): 282-4.

Lainson R, Shaw JJ, Silveira FT, Souza AAA, Braga RR, Ishikawa EAY. The dermal leishmaniases of Brazil, with special reference to the ecoepidemiology of the disease in Amazonia. Mem Inst Oswaldo Cruz 1994; 89: $435-43$.

Leopoldo e Silva R, Corrêa FMA, Gomes AC, Yoshida ELA. Investigação epidemiológica sobre leishmaniose tegumentar americana no Municipio de Conchas, Estado de São Paulo, Brasil. Rev Ciênc Bioméd 1984; 5: 49-55. 
Lonardoni MVC, Teodoro U, Arraes SMAA, Silveira TGV, Bertolini DA, Ishikawa EAY, Shaw JJ. Nota sobre leishmaniose canina no noroeste do Estado do Paraná, sul do Brasil. Rev Saúde Pública 1993; 27: 378-9.

Lopez M, Inga R, Cangalaya M, Echevarria J, Llanos-Cuentas A, Orrego C, Arevalo J. Diagnosis of Leishmania using the polymerase chain reaction: a simplified procedure for field work. Am J Trop Med Hyg 1993; 49(3): 348-56.

Luz E, Membrive N, Castro EA, Dereure J, Pratlong F, Dedet JA, Pandey A, Thomaz-Soccol V. Lutzomyia whitmani (Díptera: Psychodidae) as vector of Leishmania (V.) braziliensis in Parana state, southern Brazil. Ann Trop Med Parasitol 2000; 94(6): 623-31.

Machado-Coelho GLL, Vitor RWA, Chiari CA, Antunes CMF. Validity of serology for American trypanosomiasis with eluates from filter paper. Mem Inst Oswaldo Cruz 1995; 90(1): 59-64.

Madeira MMF, Uchoa CM, Leal CA, Macedo Silva RM, Duarte R, Magalhães CM, Barrientos Serra CM. Leishmania (Viannia) braziliensis in naturally infected dogs. Rev Soc Bras Med Trop 2003; 36(5): 551-5. 
Magalhães Rocha NM, Melo MN, Babá EH, Dias M, Michalick MSM, Costa CA, Williams P, Mayrink W. Leishmania braziliensis braziliensis isolated from Akodon arviculoides captured in Caratinga, Minas Gerais, Brazil. Trans $\mathbf{R}$ Soc Trop Med Hyg 1988; 82: 68.

Mancianti F, Gradoni L, Gramieri S, Marconcini A. Canine leishmaniasis in the Isle of Elba. Trop Med Parasitol 1986; 37: 110-12.

Manson-Bahr PEC. Diagnosis, p 703-729. In: Peters W, Killick-Kendrick R, editors. The leishmaniasis in biology and medicine. Vol 2, London: Academic Press; 1987.

Marzochi MCA, Grimaldi Jr. G, Momen H, McMahon-Pratt D. Visceral Leishmania braziliensis braziliensis infection in a dog in Rio de Janeiro (Brazil). In: Reunião Anual sobre Pesquisa Básica em Doença de Chagas, 10a , Caxambu, 1983. Resumos. Belo Horizonte, CNPq, 1983. p.15.

Marzochi MCA, Souza WJS, Coutinho SG, Toledo LM, Grimaldi Jr G, Momen $H$. Evaluation of diagnostic criteria in human and canine mucocutaneous leishmaniasis in a Rio de Janeiro District where Leishmania braziliensis braziliensis occurs. In: Reunião Anual sobre Pesquisa Básica em Doença de Chagas, 9a Caxambu, 1982. Resumos. Belo Horizonte, CNPq, 1982. p.63. 
Marzochi MCA. Leishmanioses no Brasil: as leishmanioses tegumentares. J Bras Med 1992; 63(5/6): 82-104.

Marzochi MCA, Marzochi KBF. Tegumentary and visceral leishmaniases in Brazil - emerging anthropozoonosis and possibilities for their control. Cad Saúde Pública 1994; 10 Suppl 2: 359-75.

Marzochi MCA, Marzochi KBF, Carvalho RW. Visceral leishmaniasis in Rio de Janeiro. Parasitol Today 1994; 10: 37-40.

Marzochi MCA, Coutinho SG, Sabroza PC, Souza WJS. Reação de imunofluorescência indireta e intradermorreação para leishmaniose tegumentar americana em moradores na área de Jacarepaguá (Rio de Janeiro). Estudo comparativo dos resultados observados em 1974 e 1978. Rev Inst Med Trop São Paulo 1980; 22: 149 - 55.

Mello DA, Rego Jr.FA, Oshiro E, Nunes VLB. Cerdocyon thous (Carnivora, Canidae) naturally infected with Leishmania donovani chagasi (Cunha \& Chagas, 1937) in Corumbá (Mato Grosso do Sul State, Brazil). Mem Inst Oswaldo Cruz 1988; 83: 259.

Mendonça SCF, Souza WJS, Nunes MP, Marzochi MCA, Coutinho SG. Indirect immunofluorescence test in New World leishmaniasis: serological and clinical relationship. Mem Inst Oswaldo Cruz 1988; 83: 347-55. 
Menezes Filho JF, Barros RMG, Silva AL, Mambelli M, Silva PG. Leishmaniose cutâneo-mucosa ou tegumentar americana. Revisão da literatura e caso clínico. Odontol Mod 1986; 13: 32-42.

Michalsky EM, Fortes-Dias CL, Pimenta PFP, Secundino NFC, Dias ES. Assessment of PCR in the detection of Leishmania spp in experimentally infected individual phlebotomine sandflies (Diptera: Psychodidae: Phlebotominae). Rev Inst Med Trop São Paulo 2002; 44(5): 255-9.

Migone LE.Um caso de kalazar a Assuncion (Paraguai). Bull Soc Pathol Exot 1913; 6:118-20.

Ministério da Saúde. Fundação Nacional de Saúde. Coordenação Nacional de Dermatologia Sanitária (CENEPI). Guia de controle da leishmaniose

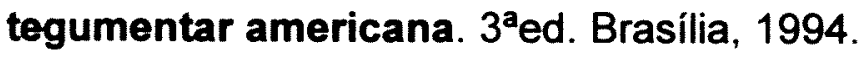

Ministério da Saúde. Fundação Nacional de Saúde. Coordenação Nacional de Dermatologia Sanitária (CENEPI). Situação da Prevenção e Controle das Doenças Transmissíveis no Brasil. Brasília, 2002a.

Ministério da Saúde. Fundação Nacional de Saúde. Leishmaniose tegumentar americana e leishmaniose visceral (calazar). Distribuição de casos confirmados, por Unidade Federada. Brasil, 1980-2001. ["on line", 04/ 09/2002b, disponivel em http://www.funasa.gov.br/epi]. 
Miranda JC, Reis E, Schriefer A, Gonçalves M, Reis MG, Carvalho L, Fernandes O, Barral-Neto M, Barral A. Frequency of infection of Lutzomyia Phlebotomines with Leishmania braziliensis in a Brazilian endemic area as assessed by pinpoint capture and polimerase chain reaction. Mem Inst Oswaldo Cruz 2002; 97(2): 185-8.

Monteiro PS, Lacerda MM, Arias JR. Controle da leishmaniose visceral no Brasil. Rev Soc Bras Med Trop 1994; 27 Supl 3: 67-72.

Morrison AC, Ferro C, Tesh RB. Host preferences of sand fly Lutzomyia longipalpis at an endemic focus of American visceral leishmaniais in Colombia. Am J Trop Med Hyg 1993; 49(1): 68-75.

Nascimento MDSB. Leishmaniose tegumentar no Estado de Goiás: análise dos dados epidemiológicos, clínicos e imunopatológicos da infeç̧ăo humana, registrados de 1965 a 1984. Rev Patol Trop 1986; 15: 99-214.

Natal D, Marucci D, Reis IM, Galati EAB. Modificações da armadilha CDC com testes para coletas de flebotomíneos (Diptera). Rev Bras Entomol 1991; 35: 697-700.

Nunes VLB, Yamamoto YI, Rego Jr. F de A, Dorval MEC, Galati EAB, Oshiro $E T$, Rodrigues M. Aspectos epidemiológicos da leishmaniose visceral em cães de Corumbá, Mato Grosso do Sul. Pesq Vet Bras 1988; 8: 17- 21. 
Nunes VLB, Oshiro ET, Dorval MEC, Espindola MA, Cristaldo G, G, Rocha $\mathrm{HC}$ et al. Estudo epidemiológico sobre leishmaniose tegumentar (LT) no Municipio de Corguinho, Mato Grosso do Sul: estudos de reservatórios, 1992-1994. Rev Bras Parasitol Vet 1994; 3: 29-45.

Nunes VLB, Dorval MEC, Oshiro ET, Arão LB, Hans Filho G, Espíndola MA, Cristaldo G, Rocha HC, Serafini LN, Santos D. Estudo epidemiológico sobre leishmaniose tegumentar (LT) no Municipio de Corguinho, Mato Grosso do Sul. Estudos na população humana. Rev Soc Bras Med Trop 1995; 28 : 185-93.

Nunes VLB. Protozoarios tripanosomatideos encontrados em animais domésticos e silvestres em área do Planalto e do Pantanal Sul-matogrossense. Mem Inst Oswaldo Cruz 1996; 91 Suppl 27.

Nunes VLB. Condicionantes para a transmissão de leishmanioses em assentamento agrícola do INCRA e adjacências, Planalto da Bodoquena, Estado do Mato Grosso do Sul, Brasil, 1998-1999. São Paulo; 2001. [Tese de Doutorado - Faculdade de Saúde Pública da Universidade de São Paulo]. 
Nunes VLB, Galati EAB, Nunes DB, Zinezzi RO, Savani ESMM, Ishikawa E, Camargo MCGO, D'Auria SRN, Cristaldo G, Rocha HC. Ocorrência de leishmaniose visceral canina em assentamento agrícola no Estado do Mato Grosso do Sul. Rev Soc Bras Med Trop 2001; 34: 299-300.

Oliveira AC. Um caso de leishmaniose visceral americana. Hospital 1938; 13: $465-70$.

Oliveira AG. Estudo da fauna flebotomínea (Diptera: Psychodidae), na zona urbana de Campo Grande, Mato Grosso do Sul, Brasil, 1999-2000. Rio de Janeiro; 2000. [Dissertação de Mestrado - Fundação Instituto Oswaldo Cruz].

Organização Pan-Americana da Saúde. Organização Mundial da Saúde. Manual de controle da leishmaniose visceral. Brasília, 1997.

Palatnik-de-Sousa CB, Santos WR, França-Silva JC, Costa RT, Reis AB, Palatnik M, Mayrink W, Genaro O. Impact of canine control on the epidemiology of canine and human visceral leishmaniasis in Brazil. Am J Trop Med Hyg 2001; 65(5): 510-17. 
Paranhos-Silva M, Freitas LAR, Santos WC, Grimaldi Jr G, Pontes-deCarvalho LC, Oliveira-dos-Santos AJ. A cross-sectional serodiagnostic survey of canine leishmaniasis due to Leishmania chagasi. Am J Trop Med Hyg 1996; 55(1): 39-44.

Paranhos-Silva M, Oliveira GGS, Reis EA, Menezes RMC, Fernandes O, Sherlock I, Gomes RBB, Pontes-de-Carvalho LC, dos-Santos WLC. A followup of Beagle dogs intradermally infected with Leishmania chagasi in presence or absence of sand fly saliva. Vet Parasitol 2003; 114(2): 97-111.

Perez JE, Villaseca P, Cáceres A, Lopez M, Zolessi A, Campos M, Guerra H, Llanos-Cuentas. Leishmania (Viannia) peruviana isolated from the sandfly Lutzomyia peruensis (Diptera: Psychodidae) and sentinel hamster in the Huayllacallán valley (Ancash, Peru). Trans R Soc Trop Med Hyg 1991; 85: 60.

Perez JE, Ogusuku E, Inga R, Lopez M, Monje J, Paz L, Nieto E, Arevalo J, Guerra H. Natural Leishmania infection of Lutzomyia spp in Peru. Trans R Soc Trop Med Hyg 1994; 88: $161-4$.

Pessôa SB, Coutinho JO. Infecçãc natural e experimental dos flebótomos pela Leishmania braziliensis no Estado de São Paulo. Hospital 1941; 20: 25-35. 
Pessôa SB, Barreto MP. Leishmaniose tegumentar americana. Rio de Janeiro: Imprensa Nacional; 1948.

Pessôa SB, Martins A. Parasitologia médica. $11^{a}$ ed. Rio de Janeiro: Guanabara Koogan; 1982.

Peterson NE, Vexenat A, Rosa AC, Lago PRL. Isolation of Leishmania (Viannia) braziliensis from the rodent Nectomys squamipes captured in Bahia, Brazil. Mem Inst Oswaldo Cruz 1988; 83 Suppl 1: 39.

Pirmez C, Coutinho SG, Marzochi MCA, Nunes MP, Grimaldi Jr G. Canine American leishmaniasis: a clinical and immunological study in dogs naturally infected with Leishmania braziliensis braziliensis in an endemic area of Rio de Janeiro, Brazil. Am J Trop Med Hyg 1988; 38: 52-8.

Queiroz RG, Vasconcelos IA, Vasconcelos AW, Pessoa FA, Sousa RN, David JR. Cutaneous leishmaniasis in Ceara state in northeastern Brazil: incrimination of Lutzomyia whitmani (Diptera: Psychodidae) as a vector of Leishmania braziliensis in Baturite municipality. Am J Trop Med Hyg 1994; 50(6): 693-8. 
Quinnell RJ, Courtenay O, Davidson S, Garcez L, Lambson B, Ramos P, Shaw JJ, Shaw MA, Dye C. Detection of Leishmania infantum by PCR, serology and cellular immune response in a cohort study of Brazilian dogs. Parasitology 2001; 122: 253-61.

Rangel EF, Souza NA, Wermelinger ED, Barbosa AF. Natural infection of Lutzomyia intermedia Lutz \& Neiva, 1912, in as endemic area of cutaneous leishmaniasis of Rio de Janeiro. Mem Inst Oswaldo Cruz 1984; 79(3): 3956.

Rangel EF, Ryan L, Lainson R, Shaw JJ. Observations on the sandfly (Diptera: Psychodidae) fauna of Alem Paraiba, State of Minas Gerais, Brazil, and the isolation of a parasite of the Leishmania braziliensis complex from Psychodopygus hirsuta hirsuta. Mem Inst Oswaldo Cruz 1985; 80(3): 3734.

Reithinger R, Davies CR. Is the domestic dog (Canis familiaris) a reservoir host of American cutaneous leishmaniasis? A critical review of the current evidence. Am J Trop Med Hyg 1999; 61(4): 530-41.

Reithinger R, Lambson BE, Barker DC, Davies CR. Use of PCR to detect Leishmania (Viannia) spp in dog blood and bone marrow. J Clin Microbiol 2000; 38(2): 748-51. 
Reithinger R, Davies CR. American cutaneous leishmaniasis in domestic dogs: an example of the use of the polymerase chain reaction for mass screening in epidemiological studies. Trans R Soc Trop Med Hyg 2002; 96 Suppl 1: 123-6.

Reithinger R, Lambson BE, Barker DC, Counihan H, Espinoza CJ, Gonzalez JS, Davies CR. Leishmania (Viannia) spp. dissemination and tissue tropism in naturally infected dogs (Canis familiaris). Trans $\mathbf{R}$ Soc Trop Med Hyg 2002a; 96(1): 76-8.

Reithinger R, Quinnell RJ, Alexander B, Davies CR. Rapid detection of Leishmania infantum in dogs: comparative study using an immunochromatographic dipstick test, enzyme-linked immunosorbent assay, and PCR. J Clin Microbiol 2002b; 40(7): 2352-6.

Reithinger R, Espinoza CJ, Courtenay O, Davies CR. Evaluation of PCR as a diagnostic mass-screening tool to detect Leishmania (Viannia) spp in domestic dogs (Canis familiaris). J Clin Microbiol 2003; 41(4): 1486-93.

Roberts DR, Hsi BP. An index of species abundance for use with mosquito survillance data. Environ Entomol 1979; 8: 1007-13. 
Rodriguez N, Aguilar CM, Barrios MA, Barker DC. Detection of Leishmania braziliensis in naturally infected individual sandflies by the polymerase chain reaction. Trans $\mathbf{R}$ Soc Trop Med Hyg 1999; 93: 47-49.

Rodriguez N, De Lima H, Aguilar CM, Rodriguez A, Barker DC, Convit J. Molecular epidemiology of cutaneous leishmaniasis in Venezuela. Trans $\mathbf{R}$ Soc Trop Med Hyg 2002; 96 Suppl 1: 105-9.

Rosa AC, Cuba CC, Vexenat A, Barreto AC, Marsden PD. Predominance of Leishmania braziliensis braziliensis in the regions of Três Braços and Corte de Pedra, Bahia, Brazil. Trans R Soc Trop Med Hyg 1988; 82: 409-10.

Rose K, Curtis J, Baldwin T, Mathis A, Kumar B, Sakthianandeswaren A, Spurck T, Low Choy J, Handman E. Cutaneous leishmaniasis in red kangaroos: isolation and characterization of the causative organisms. Int $\mathbf{J}$ Parasitol 2004; 34(6): 655-64.

Ryan L, Vexenat A, Marsden PD, Lainson R, Shaw JJ. The importance of rapid diagnosis of new cases of cutaneous leishmaniasis in pin-pointing the sandfly vector. Trans R Soc Trop Med Hyg 1990; 84(6): 786. 
San Martin-Savani EM. Inquérito sorológico sobre leishmaniose tegumentar americana em cães errantes do Município de São Paulo, 1995-1996. São Paulo; 1998. [Dissertação de Mestrado - Faculdade de Saúde Pública da Universidade de São Paulo].

Sanger F, Air GM, Barrell BG, Brown NL, Coulson AR, Fiddes CA, Hutchison CA, Slocombe PM, Smith M. Nucleotide sequence of bacteriophage phi X174 DNA. Nature $1977 ; 265: 687-95$.

Santa Rosa ICA, Oliveira ICS. Leishmaniose visceral: breve revisão sobre uma zoonose reemergente. Clin Vet $1997 ; 2: 24-8$.

Santos SO dos, Arias JR, Ribeiro AA, Hoffmann M de P, Freitas RA de, Malacco MAF. Incrimination of Lutzomyia cruzi as a vector of American Visceral Leishmaniasis. Med Vet Entomol 1998; 12: 315-17.

Santos SO dos, Arias JR, Hoffmann M de P, Furlan MBG, Ferreira WF, Pereira C, Ferreira L. The presence of Lutzomyia longipalpis in a focus of American visceral leishmaniasis where the only proven vector is Lutzomyia cruzi. Corumba, Mato Grosso do Sul State. Rev Soc Bras Med Trop 2003; $36(5): 633-4$. 
Secretaria de Estado da Saúde do Mato Grosso do Sul. Casos de leishmaniose visceral com óbito - 1995 a 2002. Campo Grande, 2002a.

Secretaria de Estado da Saúde do Mato Grosso do Sul. Coordenação Estadual de Controle de Vetores. Mapeamento de vetores de leishmaniose visceral. ["on line", 04/09/2002b, disponivel em http://www.geocities.com/entomologia2000].

Service MW. Mosquito ecology: field sampling methods. London. Chapman \& Hall; 1993. 988p.

Shaw JJ, Ishikawa EAY, Lainson R. A rapid and sensitive method for the identification of Leishmania with monoclonal antibodies using fluoresceinlabelled avidin. Trans R Soc Trop Med Hyg 1989; 83: 783-4.

Shaw JJ, Ishikawa EAY, Lainson R, Braga RR, Silveira FT. Cutaneous leishmaniasis of man due to Leishmania (Viannia) shawi Lainson, de Souza, Povoa, Ishikawa \& Silveira, in Para State, Brazil. Ann Parasitol Hum Comp 1991; 66(6): 243-6.

Sherlock IA, Miranda JC, Sadigursky M, Grimaldi Jr. G. Natural infection of the opossum Didelphis albiventris (Marsupialia, Didelphidae) with Leishmania donovani, in Brazil. Mem Inst Oswaldo Cruz 1984; 79: 511. 
Sherlock IA. Interação ecológica da Lutzomyia longipalpis com a Leishmania chagasi na epidemiologia da leishmaniose visceral americana. Rev Soc Bras Med Trop 1994; 27 Suppl 4: 579-82.

Sherlock IA. Ecological interactions of visceral leishmaniasis in the State of Bahia, Brazil. Mem Inst Oswaldo Cruz 1996; 97: 671-83.

Silva AR da, Viana GMC, Varonil C, Pires B, Nascimento M do DSD, Costa JML. Leishmaniose visceral (Calazar) na ilha de São Luís, Maranhão, Brasil: evolução e perspectivas. Rev Soc Bras Med Trop 1997; 30: 359-68.

Silva ES, Gontijo CMF, Pirmez C, Fernandes O, Brazil RP. Short report: detection of Leishmania DNA by polymerase chain reaction on blood samples from dogs with visceral leishmanaisis. Am J Trop Med Hyg 2001; 65(6): 896-8.

Silva ES, Pacheco RS, Gontijo CMF, Carvalho IR, Brazil RP. Visceral leishmaniasis caused by Leishmania (Viannia) braziliensis in a patient infected with human immunodeficiency virus. Rev Inst Med Trop São Paulo 2002; 44: 145-9.

Silva OS, Grunewald J. Contribution to the Sand Fly Fauna (Diptera: Phlebotominae) of Rio Grande do Sul, Brazil and Leishmania (Viannia) Infections. Mem Inst Oswaldo Cruz 1999; 94(5): 579-82. 
Silveira FT, Lainson R, Shaw JJ, Povoa MM. Leishmaniasis in Brazil: XVII. Further evidence incriminating the fox Cerdocyon thous as a reservoir of Amazonian visceral leishmaniasis. Trans R Soc Trop Med Hyg 1982; 76 : 830-2.

Silveira FT, Shaw JJ, Braga RR, Ishikawa E. Dermal leishmaniasis in the Amazon region of Brazil: Leishmania (Viannia) lainsoni sp. n., a new parasite from the state of Pará. Mem Inst Oswaldo Cruz 1987; 82(2): 289-92.

Silveira FT, Ishikawa EAY, De Souza AA, Lainson R. An outbreak of cutaneous leishmaniasis among soldiers in Belém, Para State, Brazil, caused by Leishmania (Viannia) lindenbergi n. sp. A new leishmanial parasite of man in the Amazon region. Parasite 2002; 9(1): 43-50.

Silveira TG, Teodoro U, Arraes SM, Lonardoni MV, Dias ML, Shaw JJ, Ishikawa EA, Lainson R. An autochthonous case of cutaneous leishmaniasis caused by Leishmania (Leishmania) amazonensis Lainson \& Shaw, 1972 from the north of Paraná State, Brazil. Mem Inst Oswaldo Cruz 1990; 85: 475-6.

Singh S, Sivakumar R. Recent advances in the diagnosis of leishmaniasis. J Postgrad Med 2003; 49: 55-60. 
Southern, EM. Detection of specific sequences among DNA fragments separated by gel electrophoresis. J Mol Biol 1975; 98: 503-17.

Souza SL, Camargo ME. The use of filter paper blood smears in a practical fluorescent test for American trypanosomiasis serodiagnosis. Rev Inst Med Trop São Paulo 1966; 8(6): 255-58.

Stevens JR, Nunes VL, Lanham SM, Oshiro ET. Isoenzyme characterization of Trypanosoma evansi isolated from capybaras and dogs in Brazil. Acta Trop 1989; 46(4): 213-22.

Thomaz-Soccol V, Lanotte G, Rioux JA, Pratlong F, Martini-Dumas A,Serres E. Phylogenetic taxonomy of New World Leishmania. Ann Parasitol Hum Comp 1993; 68: 104-6.

Tolezano JE. Ecoepidemiological aspects of American cutaneous leishmaniasis in the State of São Paulo, Brazil. Mem Inst Oswaldo Cruz 1994; 89: 427-34.

Tolezano JE, Luvizotto MCR, Uliana SRB, Araújo MFL, Taniguchi HH, Barbosa JAR, et al. Leishmaniose visceral americana (LVA) em Araçatuba, região oeste do Estado de São Paulo. Investigações laboratoriais e diagnóstico etiológico de uma doença emergente em terras paulistas. Rev Soc Bras Med Trop 1999; 32 Suppl 1: 218. 
Tolezano JE. Ecoepidemiologia da Leishmaniose Tegumentar Americana (LTA). Perpetuação da LTA no Estado de São Paulo, região endêmica de colonização antiga. São Paulo; 2000. [Tese de Doutorado Instituto de Ciências Biomédicas da Universidade de São Paulo].

Travi BL, Jamarillo C, Montoya J, Segura I, Zea A, Gonçalves A, Velez ID. Didelphis marsupialis, an important reservoir of Trypanosoma (Schizotrypanum) cruzi and Leishmania (Leishmania) chagasi in Colombia. Am J Trop Med Hyg 1994; 50: 557-65.

Travi BL, Montoya J, Gallego J, Jamarillo C, Llano R, Velez ID. Bionomics of Lutzomyia evansi (Diptera: Psychodidae) vector of visceral leishmaniasis in northern Columbia. J Med Entomol 1996; 33(3): 278-85.

Travi BL, Tabares CJ, Cadena H, Ferro C, Osório Y. Canine visceral leishmaniasis in Colombia: relationship between clinical and parasitologic status and infectivity for sand flies. Am J Trop Med Hyg 2001; 64: 119-24.

Uliana SRB, Affonso MHT, Camargo EP, Floeter-Winter LM. Leishmania: genus identification based on a specific sequence of the 18S ribosomal RNA sequence. Exp Parasitol 1991; 72: $157-63$. 
Uliana SRB, Nelson K, Beverley SM, Camargo EP, Floeter-Winter LM. Discrimination amongst Leishmania by polymerase chain reaction and hybridization with small subunit ribosomal DNA derived oligonucleotides. J Euk Microbiol 1994; 41(4): 324-30.

Uliana SRB, Ishikawa E, Stempliuk VA, Souza A, Shaw JJ, Floeter-Winter LM. Geographical distribution of neotropical Leishmania of the subgenus Leishmania analysed by ribosomal oligonucleotide probes. Trans $\mathbf{R}$ Soc Trop Med Hyg 2000; 94: 261-64.

Vasconcelos IAB, Vasconcelos AW, Fé Filho NM, Queiroz RG, Santana EW, Bozza $M$, et al. The identify of Leishmania isolated from sandflies and vertebrate hosts in a major focus of cutaneous leishmaniasis, Baturité, Northeastern Brazil. Am J Trop Med Hyg 1994; 50:158-64.

Veloso HP, Rangel-Filho ALR, Lima JCA. Classificação da vegetação brasleira, adaptada a um sistema universal. Rio de Janeiro, IBGE, Departamento de Recursos Naturais e Estudos Ambientais, 1991. 124p.

Vexenat JA, Barreto AC, Cuba CC, Marsden PD. Epidemiological characteristics of American cutaneous leishmaniasis in an endemic region of the state of Bahia. III. Phlebotomine fauna. Mem Inst Oswaldo Cruz 1986; 81(3): 293-301. 
Walton BC, Brooks WH, Arjona I. Serodiagnosis of American leishmaniasis by indirect fluorescent antibody test. Am J Trop Med Hyg 1972; 21: 29699.

Walton BC, Shaw JJ, Lainson R. Observations on the in vitro cultivation of Leishmania braziliensis. J Parasitol 1977; 63(6): 1118-9.

Ximenes MF, Souza MF, Castellon EG. Density of sand flies (Diptera:Psychodidae) in domestic and wild animal shelters in an area of visceral leishmanisis in the state of Rio Grande do Norte, Brazil. Mem Inst Oswaldo Cruz 1999; 94(4): 427-32.

Yamamoto YI, Nunes VLB, Rego Jr. F de A, Oshiro ET, Dorval MEC. Estudo da eficiência das reações de imunofluorescência e de hemaglutinação passiva no diagnóstico de leishmaniose visceral em cães. Rev Fac Med Vet Zoot Univ São Paulo 1988; 25: 143-52.

Yoshida ELA, Correa FMA, Marques AS, Stolf HO, Dillon NL, Momen H, Grimaldi Jr G. Human, canine and equine (Equus caballus) leishmaniasis due to Leishmania braziliensis (= Leishmania braziliensis braziliensis) in the south-west region of São Paulo State, Brazil. Mem Inst Oswaldo Cruz 1990; 85: 133-4. 
Young DG, Duncan MA. Guide to the identification and geographic distribution of Lutzomyia sandflies in Mexico, the west Indies, Central and South America "Diptera: Psychodidae". Mem Am Entomol Inst 1994; 54: 1 881.

Zhen L, Swank RT. A simple and high yield method for recovering DNA from agarose gels. BioTechniques 1993; 14: 894-6.

Zicker F, Smith PG, Luquetti AO, Oliveira OS. Mass screening for Trypanosoma cruzi infections using the immunofluorescence, ELISA and haemagglutination tests on serum samples and on blood eluates from filterpaper. Bull World Health Organ 1990; 68(4): 465-71.

Zulueta AM, Villarroel E, Rodriguez N, Feliciangeli MD, Mazzarri M, Reyes O, Rodriguez V, Centeno M, Barrios RM, Ulrich M. Epidemiologic aspects of American visceral leishmaniasis in an endemic focus in Eastern Venezuela. Am J Trop Med Hyg 1999; 61(6): 945-50. 


\section{Universidade de São Paulo \\ Faculdade de Saúde Pública \\ COMITE DE ÉTICA EM PESQUISA - COEP}

Av. Dr. Arnaldo, 715 - CEP 01246-904 - São Paulo - Brasil

Telefones: (55-11) 3066- 7734 - fone/fax (55-11) 3064-7314 - e-mail: mdgracas@usp.br

Of.COEP/196/02

10 de junho de 2002

Pelo presente, informo que o Comitê de Ética em Pesquisa da Faculdade

de Saúde Pública da Universidade de São Paulo-COEP, analisou, o Protocolo de Pesquisa n. $^{\circ} 822$, intitulado: "ASPECTOS DA TRANSMISSÃO DE LEISHMANIOSES NO ASSENTAMENTO GUAICURUS E ADJACÊNCIAS, PLANALTO DA BODOQUENA, ESTADO DE MATO GROSSO DO SUL, 2002-03. INFECÇÃO NATURAL EM ANIMAIS DOMÉSTICOS E VETORES”, apresentado pela pesquisadora Elisa San Martin Mouriz Savani, e por não se tratar de pesquisa envolvendo seres humanos, não há necessidade de parecer deste Comitè.

Atenciosamente,

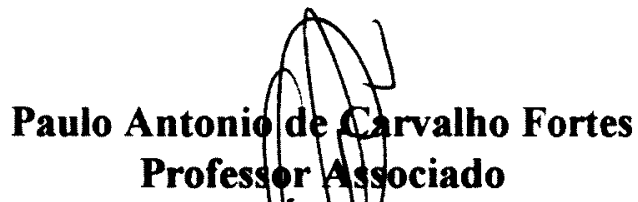

Coordenador do Comitê de tich em Pesquisa da FSP-COEP 
Anexo 2: Resultados da reação de imunofluorescência indireta (RIFI) e ensaio imunoenzimático (EIE) em amostras de soro e sangue em papel filtro dos cães do Assentamento Guaicurus, fevereiro e março de 2003.

\begin{tabular}{|c|c|c|c|c|c|}
\hline \multirow[t]{2}{*}{ LOTE } & \multirow{2}{*}{$\mathrm{N}^{\circ}$ E NOME DO CÃO } & \multicolumn{2}{|c|}{ SORO } & \multicolumn{2}{|c|}{ PAPEL FILTRO } \\
\hline & & RIFI & EIE & RIFI & EIE \\
\hline 124 & I RUCK & Não Reagente & Não Reagente & Não Reagente & Não Reagente \\
\hline 124 & 2 RATINHO & Não Reagente & Não Reagente & Não Reagente & Não Reagente \\
\hline 124 & 3 TROVÃO & 160 & Reagente & Não Reagente & Reagente \\
\hline 124 & 4 PITOCO & Não Reagente & Inconclusivo & Não Reagente & Não Reagente \\
\hline 122 & 5 XAROPINHO & Não Reagente & Reagente & Não Reagente & Reagente \\
\hline 122 & $6 \mathrm{BS}$ & Não Reagente & Não Reagente & Não Reagente & Não Reagente \\
\hline 122 & 7 NEGUINHO & Não Reagente & Não Reagente & Não Reagente & Não Reagente \\
\hline 121 & 8 LELE & Não Reagente & Não Reagente & Não Reagente & Não Reagente \\
\hline 121 & 9 CHICOTE & Não Reagente & Não Reagente & Não Reagente & Não Reagente \\
\hline 121 & 10 BURITI & Não Reagente & Reagente & Não Reagente & Inconclusivo \\
\hline 121 & 11 FAISCA & $\mathrm{N} \approx$ o Reagente & Não Reagente & Não Reagente & Não Reagente \\
\hline 125 & 12 PITOCO & Não Reagente & Não Reagente & Não Reagente & Não Reagente \\
\hline 125 & 13 LONTRA & Não Reagente & Não Reagente & Não Reagente & Não Reagente \\
\hline 125 & 14 XERETA & Năo Reagente & Não Reagente & Não Reagente & Não Reagente \\
\hline 126 & 15 JUPI & Não Reagente & Não Reagente & Não Reagente & Não Reagente \\
\hline 126 & 16 CAMOIO & Não Reagente & Reagente & Não Reagente & Reagente \\
\hline 118 & 17 NEGUINHO & Não Reagente & Reagente & Não Reagente & Reagente \\
\hline 128 & 18 FRED & Não Reagente & Não Reagente & Não Reagente & Não Reagente \\
\hline 117 & 19 DUQUE & 160 & Não Reagente & Reagente & Não Reagente \\
\hline 115 & 20 TEQUE & 320 & Reagente & Reagente & Reagente \\
\hline 115 & 21 PANDORGA & Năo Reagente & Não Reagente & Năo Reagente & Não Reagente \\
\hline 114 & 22 LUPI & Não Reagente & Não Reagente & Não Reagente & Não Reagente \\
\hline 25 & 23 FURCÃO & Não Reagente & Não Reagente & Não Reagente & Não Reagente \\
\hline 25 & 24 MADRUGA & Não Reagente & Reagente & Não Reagente & Não Reagente \\
\hline 16 & 25 MALHADO & 40 & Reagente & Nån Reagente & Reagente \\
\hline 16 & 26 NEGÃO & $\mathrm{N} \mathrm{J}_{0}$ Reagente & Năo Reagente & Nðo Reagente & Nåo Reagente \\
\hline 24 & 27 JAVANTE & Não Reagente & Reagente & Não Reagente & Inconclusivo \\
\hline 24 & 28 JAVICA & Não Reagente & Não Reagente & Não Reagente & Nåo Reagente \\
\hline 18 & 29 LAICA & Não Reagente & Não Reagente & Não Reagente & Não Reagente \\
\hline
\end{tabular}




\begin{tabular}{|c|c|c|c|c|c|}
\hline \multirow[t]{2}{*}{ LOTE } & \multirow{2}{*}{$\mathrm{N}^{\circ} \mathrm{E}$ NOME DO CÃO } & \multicolumn{2}{|c|}{ SORO } & \multicolumn{2}{|c|}{ PAPEL FILTRO } \\
\hline & & RIFI & EIE & RIFI & EIE \\
\hline 18 & 30 LULA & Não Reagente & Inconclusivo & Não Reagente & Não Reagente \\
\hline 19 & 31 NIQUE & Não Reagente & Nåo Reagente & Não Reagente & Não Reagente \\
\hline 19 & 32 LEÃO & Não Reagente & Não Reagente & Não Reagente & Não Reagente \\
\hline 22 & 33 CHALANA & Não Reagente & Não Reagente & Năo Reagente & Não Reagente \\
\hline 22 & 34 PANTERA & Não Reagente & Não Reagente & Não Reagente & Não Reagente \\
\hline 27 & 35 BARÃO & 80 & Reagente & Reagente & Não Reagente \\
\hline 27 & 36 TARZAN & 320 & Reagente & Reagente & Reagente \\
\hline 13 & 37 DELEGADO & 160 & Reagente & Reagente & Reagente \\
\hline 13 & 38 NIQUE & Não Reagente & Não Reagente & Não Reagente & Nåo Reagente \\
\hline 25 & 39 LOLICA & Não Reagente & Reagente & Não Reagente & Nææo Reagente \\
\hline 119 & 40 BILA & Não Reagente & Não Reagente & Não Reagente & Nåo Reagente \\
\hline 119 & 41 BILICO & Não Reagente & Não Reagente & Não Reagente & Não Reagente \\
\hline 12 & 42 CAMPEÃO & Não Reagente & Não Reagente & Năo Reagente & Næo Reagente \\
\hline 28 & 43 TANDI & Não Reagente & Não Reagente & Nåo Reagente & Não Reagente \\
\hline 28 & 44 BETOVEM & Não Reagente & Não Reagente & Năo Reagente & Nåo Reagente \\
\hline 11 & 45 LULU & Não Reagente & Não Reagente & Não Reagente & Nǎo Reagente \\
\hline 11 & 46 MALU & Não Reagente & Não Reagente & Nð。 Reagente & Næo Reagente \\
\hline 11 & 47 PILOTO 2 & Não Reagente & Não Reagente & Não Reagente & Näo Reagente \\
\hline 11 & 48 PILOTO 1 & Não Reagente & Não Reagente & Não Reagente & Não Reagente \\
\hline 11 & 49 LAQUICHA & Não Reagente & Não Reagente & Não Reagente & Não Reagente \\
\hline 118 & 50 CAMPEIRA & Não Reagente & Não Reagente & Nåo Reagente & Nåo Reagente \\
\hline 9 & 51 TITIO & Não Reagente & Não Reagente & Não Reagente & Nāo Reagente \\
\hline 30 & 52 RALF & Não Reagente & Não Reagente & Não Reagente & Năo Reagente \\
\hline 8 & 53 DUQUESA & Não Reagente & Reagente & Não Reagente & Nåo Reagente \\
\hline 8 & 54 REGUINHO & Năo Reagente & Não Reagente & Não Reagente & Nåo Reagente \\
\hline 8 & $55 \mathrm{JACK}$ & Não Reagente & Não Reagente & Não Reagente & Năo Reagente \\
\hline 8 & 56 BETOVEM & Não Reagente & Não Reagente & Nåo Reagente & Nå Reagente \\
\hline 3 & 57 JACK & Não Reagente & Não Reagente & Não Reagente & $\mathrm{Naz}$ Reagente \\
\hline 2 & 58 PEIXOTO 1 & Não Reagente & Não Reagente & Não Reagente & Não Reagente \\
\hline 2 & 59 PEIXOTO 2 & Não Reagente & Não Reagente & Næo Reagente & Nå Reagente \\
\hline 55 & 60 BENTINHO & Não Reagente & Não Reagente & Não Reagente & Nao Reagente \\
\hline 3 & 61 LASSIE & Nåo Reagente & Nåo Reagente & Nåo Reagente & Nåo Reagente \\
\hline
\end{tabular}




\begin{tabular}{|c|c|c|c|c|c|}
\hline \multirow{2}{*}{ LOTE } & \multirow{2}{*}{$N^{\circ}$ E NOME DO CÃO } & \multicolumn{2}{|c|}{ SORO } & \multicolumn{2}{|c|}{ PAPEL FILTRO } \\
\hline & & RIFI & EIE & RIFI & EIE \\
\hline 3 & 62 PETRUCIO & Não Reagente & Não Reagente & Não Reagente & Não Reagente \\
\hline 4 & 63 MONIQUE & Não Reagente & Não Reagente & Não Reagente & Não Reagente \\
\hline 3 & 64 RABUDO & Não Reagente & Não Reagente & Não Reagente & Não Reagente \\
\hline 128 & 65 CHEICK & Não Reagente & Reagente & Não Reagente & Não Reagente \\
\hline 2 & 66 DUQUE & 40 & Reagente & Não Reagente & Reagente \\
\hline 1 & 67 LEÃO & Não Reagente & Não Reagente & Não Reagente & Não Reagente \\
\hline 1 & 68 ESTRANGEIRO & Não Reagente & Năo Reagente & Não Reagente & Năo Reagente \\
\hline 1 & 69 AMERICANA & Não Reagente & Não Reagente & Não Reagente & Não Reagente \\
\hline 4 & 70 XEIQUE & Não Reagente & Não Reagente & Não Reagente & Não Reagente \\
\hline 4 & 71 NEGÃO & Não Reagente & Não Reagente & Não Reagente & Não Reagente \\
\hline 34 & 72 CHULE & 80 & Reagente & Não Reagente & Reagente \\
\hline 6 & 73 TED & Não Reagente & Não Reagente & Não Reagente & Não Reagente \\
\hline 53 & 74 MALAHADO & Não Reagente & Não Reagente & Não Reagente & Não Reagente \\
\hline 53 & 75 PINGO & Não Reagente & Não Reagente & Nåo Reagente & Nåo Reagente \\
\hline 35 & 76 CHIPE & Não Reagente & Não Reagente & Não Reagente & Não Reagente \\
\hline 35 & 77 FAROFA & Não Reagente & Não Reagente & Não Reagente & Não Reagente \\
\hline 35 & 78COMPANHEIRO & Não Reagente & Não Reagente & Não Reagente & Não Reagente \\
\hline 15 & 79 MIKE & Não Reagente & Reagente & Não Reagente & Não Reagente \\
\hline 48 & 80 LEÃO & Não Reagente & Nå Reagente & Não Reagente & Não Reagente \\
\hline 48 & 81 SEM NOME & Não Reagente & Não Reagente & Não Reagente & Não Reagente \\
\hline 47 & 82 FEROZ & 40 & Reagente & Não Reagente & Não Reagente \\
\hline 54 & 83 BAJUCO & Não Reagente & Não Reagente & Não Reagente & Não Reagente \\
\hline 54 & 84 CHUI & Não Reagente & Não Reagente & Não Reagente & Não Reagente \\
\hline 62 & 85 REY & Não Reagente & Não Reagente & Não Reagente & Não Reagente \\
\hline 56 & 86 ZOOMP & Não Reagente & Năo Reagente & Não Reagente & Não Reagente \\
\hline 56 & 87 CINDERELA & Não Reagente & Næ̃o Reagente & Não Reagente & Não Reagente \\
\hline 56 & 88 VITÓRIA & 640 & Reagente & Reagente & Reagente \\
\hline 57 & 89 PIRULINHO & Não Reagente & Reagente & Não Reagente & Reagente \\
\hline 57 & 90 GURI & 40 & Reagente & Não Reagente & Não Reagente \\
\hline 59 & 91 MENINA & 40 & Reagente & Não Reagente & Não Reagente \\
\hline 59 & 92 NEM & Não Reagente & Năo Reagente & Não Reagente & Não Reagente \\
\hline 59 & 93 MALHADO & 20 & Nåo Reagente & Não Reagente & Não Reagente \\
\hline
\end{tabular}




\begin{tabular}{|c|c|c|c|c|c|}
\hline \multirow{2}{*}{ LOTE } & \multirow{2}{*}{$\mathrm{N}^{\circ}$ E NOME DO CÃO } & \multicolumn{2}{|c|}{ SORO } & \multicolumn{2}{|c|}{ PAPEL FILTRO } \\
\hline & & RIFI & EIE & RIFI & EIE \\
\hline 60 & 94 PEQUENA & Não Reagente & Não Reagente & Nå Reagente & Não Reagente \\
\hline 60 & 95 BILLI & Não Reagente & Não Reagente & Năo Reagente & Não Reagente \\
\hline 61 & 96 PRISCILA & Não Reagente & Não Reagente & Não Reagente & Não Reagente \\
\hline 68 & 97 PILOTO & Não Reagente & Não Reagente & Não Reagente & Não Reagente \\
\hline 110 & $98 \mathrm{ZAGO}$ & Não Reagente & Reagente & Não Reagente & Não Reagente \\
\hline 110 & 99 SEM NOME & Não Reagente & Reagente & Não Reagente & Não Reagente \\
\hline 106 & 100 REX & Năo Reagente & Não Reagente & Não Reagente & Não Reagente \\
\hline 106 & 101 CARONA & Não Reagente & Reagente & Não Reagente & Reagente \\
\hline 106 & 102 CAMPINA & Não Reagente & Não Reagente & Não Reagente & Não Reagente \\
\hline 106 & 103 LAIKA & 80 & Reagente & Não Reagente & Não Reagente \\
\hline 106 & 104 SERTÃO & Não Reagente & Não Reagente & Não Reagente & Não Reagente \\
\hline 70 & 105 PILOTO & 80 & Reagente & Reagente & Reagente \\
\hline 70 & 106 PINGUIM & 160 & Reagente & Reagente & Reagente \\
\hline 108 & $107 \mathrm{PT}$ & 320 & Reagente & Reagente & Reagente \\
\hline 108 & 108 LEÃO & 20 & Reagente & Não Reagente & Reagente \\
\hline 108 & 109 STALONE & Não Reagente & Não Reagente & Não Reagente & Não Reagente \\
\hline 99 & 110 PISQUILA & Não Reagente & Não Reagente & Não Reagente & Não Reagente \\
\hline 95 & $111 \mathrm{REC}$ & Não Reagente & Năo Reagente & Não Reagente & Não Reagente \\
\hline 103 & 112 TUPÃ & 40 & Reagente & Não Reagente & Não Reagente \\
\hline 103 & 113 VASCO & 20 & Inconclusivo & Não Reagente & Não Reagente \\
\hline 103 & 114 CACETE & 160 & Reagente & Reagente & Reagente \\
\hline 102 & 115 FADINHA & Não Reagente & Não Reagente & Não Reagente & Não Reagente \\
\hline 102 & 116 GINGA & Não Reagente & Reagente & Não Reagente & Reagente \\
\hline 102 & 117 TIRIRICA & Não Reagente & Reagente & Não Reagente & Reagente \\
\hline 40 & 118 MILLI & 20 & Reagente & Não Reagente & Reagente \\
\hline 69 & 119 BALEIA & 20 & Reagente & Não Reagente & Reagente \\
\hline 69 & 120 XEBINHA & Não Reagente & Reagente & Não Reagente & Reagente \\
\hline 69 & $121 \mathrm{LEÃO}$ & 80 & Reagente & Reagente & Reagente \\
\hline 69 & 122 XULICA & Nð̃o Reagente & Não Reagente & Não Reagente & Não Reagente \\
\hline 69 & 123 FRONTEIRA & Nå Reagente & Reagente & Não Reagente & Não Reagente \\
\hline 73 & 124 CORCEL & Não Reagente & Não Reagente & Não Reagente & Não Reagente \\
\hline 107 & 125 DUKE & Não Reagente & Não Reagente & Não Reagente & Năo Reagente \\
\hline
\end{tabular}




\begin{tabular}{c|l|c|c|c|c}
\hline \multirow{2}{*}{ LOTE } & \multirow{2}{*}{ No E NOME DO CÃO } & \multicolumn{2}{|c|}{ RIFI } & \multicolumn{2}{c}{ PAPEL FILTRO } \\
& RIFI & \multicolumn{2}{c}{ EIE } \\
\hline 107 & 126 BABY & Não Reagente & Não Reagente & Não Reagente & Não Reagente \\
\hline 65 & 127 NEGUINHA & Não Reagente & Não Reagente & Não Reagente & Não Reagente \\
\hline 65 & 128 BOB & Não Reagente & Não Reagente & Não Reagente & Não Reagente \\
\hline 65 & 129 LASSY & Não Reagente & Não Reagente & Não Reagente & Não Reagente \\
\hline
\end{tabular}


Anexo 3: Resultados da reação de imunofluorescência indireta $(R I F I)$ e ensaio imunoenzimático (EIE) na segunda amostra de soro e sangue em papel filtro, e manifestaçöes clínicas dos cães do Assentamento Guaicurus, junho de 2003.

\begin{tabular}{|c|c|c|c|c|c|c|}
\hline \multirow[t]{2}{*}{ LOTE } & \multirow{2}{*}{$\begin{array}{l}N^{\circ} \text { E NOME DO } \\
\text { CÃO }\end{array}$} & \multicolumn{2}{|c|}{ SORO } & \multicolumn{2}{|c|}{ PAPEL FILTRO } & \multirow[t]{2}{*}{ SINTOMAS } \\
\hline & & RIFI & EIE & RIFI & EIE & \\
\hline 124 & 3 TROVẢO & 40 & $\mathbf{R}$ & NR & $R$ & Lesão de pele e onicogrifose \\
\hline 124 & 4 PITOCO & NR & $\mathbf{R}$ & NR & $\mathrm{R}$ & Assintomático \\
\hline 122 & 5 XAROPINHO & NR & NR & NR & $\mathrm{R}$ & Secreçāo ocular e onicogrifose \\
\hline 121 & 10 BURITI & NR & $\mathbf{R}$ & NR & 1 & Onicogrifose \\
\hline 126 & 16 CAMOIO & NR & $\mathbf{R}$ & NR & $\mathbf{R}$ & $\begin{array}{l}\text { Alopecia, onicogrifose, secreção ocular, } \\
\text { emagrecimento }\end{array}$ \\
\hline 118 & 17 NEGUINHO & \multicolumn{5}{|c|}{ Câo levado pelo Servico de Zoonoses do Municipio de Bonito. } \\
\hline 117 & 19 DUQUE & NR & NR & NR & NR & Assintomático \\
\hline 115 & 20 TEQUE & 80 & $\mathbf{R}$ & $\mathbf{R}$ & $\mathbf{R}$ & $\begin{array}{l}\text { Alopecia , onicogrifose, lesōes no dorso e na } \\
\text { cauda, despigmentaçäo no testiculo }\end{array}$ \\
\hline 25 & 24 MADRUGA & & & & & Cão morreu. \\
\hline 16 & 25 MALHADO & NR & $\mathbf{R}$ & NR & $\mathbf{R}$ & Assintomático \\
\hline 24. & 27 JAVANTE & NR & $\mathbf{R}$ & NR & $\mathbf{R}$ & Alopecia, emagrecimento \\
\hline 18 & 30 LULA & NR & NR & NR & NR & Assintomático \\
\hline 27 & 35 BARĀO & \multicolumn{5}{|c|}{ Cão não estava na residência no momento da visita para coleta de sangue. } \\
\hline 27 & 36 TARZAN & 160 & $\mathbf{R}$ & $\mathrm{R}$ & $\mathbf{R}$ & $\begin{array}{l}\text { Onicogrifose, secreção ocular, alopecia, } \\
\text { despigmentaçāo no focinho }\end{array}$ \\
\hline 13 & 37 DELEGADO & 320 & $\mathbf{R}$ & $\mathrm{R}$ & $\mathbf{R}$ & Onicogrifose e emagrecimento \\
\hline 25 & 39 LOLICA & \multicolumn{5}{|r|}{ Cão desapareceu. } \\
\hline 8 & 53 DUQUESA & NR & $\mathbf{R}$ & NR & NR & Onicogrifose \\
\hline 128 & 65 CHEICK & \multicolumn{5}{|c|}{ A dona recusou a nova coleta de sangue. } \\
\hline 2 & 66 DUQUE & 20 & $\mathbf{R}$ & NR & $\mathrm{R}$ & Onicogrifose \\
\hline 34 & 72 CHULE & \multicolumn{5}{|r|}{ Căo morreu } \\
\hline 15 & 79 MIKE & \multicolumn{5}{|c|}{ Năo foi possivel o acesso até a residência do animal. } \\
\hline 47 & 82 FEROZ & 40 & $\mathbf{R}$ & NR & $\mathrm{R}$ & Assintomático \\
\hline 56 & 88 VITORLA & 640 & $\mathbf{R}$ & $\mathrm{R}$ & $\mathbf{R}$ & $\begin{array}{l}\text { Onicogrifose, secreção ocular, emagrecimento e } \\
\text { lesões de pele }\end{array}$ \\
\hline 57 & 89 PIRULINHO & NR & $\mathbf{R}$ & NR & $R$ & Assintomático \\
\hline 57 & 90 GURI & 20 & $\mathbf{R}$ & NR & $\mathbf{R}$ & Assintomático \\
\hline 59 & 91 MENINA & 20 & $\mathbf{R}$ & NR & $\mathrm{R}$ & Emagrecimento \\
\hline 59 & 93 MALHADO & NR & $\mathrm{R}$ & NR & $R$ & Assintomático \\
\hline 110 & 98 ZAGO & NR & NR & NR & NR & Assintomático \\
\hline 110 & 99 SEM NOME & \multicolumn{5}{|c|}{ Cão fugiu no momento da coleta e não foi possivel encontrá-to. } \\
\hline 106 & 101 CARONA & \multicolumn{5}{|r|}{ Cão morreu. } \\
\hline 106 & 103 LAIKA & NR & NR & NR & NR & Onicogrifose e emagrecimento \\
\hline $\begin{array}{l}70 \\
70 \\
\end{array}$ & $\begin{array}{l}105 \text { PILOTO } \\
106 \text { PINGUIM }\end{array}$ & \multicolumn{5}{|c|}{$\begin{array}{c}\text { Os donos deste lote foram embora do Assentamento Guaicurus } \\
\text { e levaram os animais. }\end{array}$} \\
\hline 108 & $107 \mathrm{ET}$ & 160 & $\mathbf{R}$ & $\mathbf{R}$ & $\mathbf{R}$ & $\begin{array}{l}\text { Onicogrifose, secreção ocular, emagrecimento } \\
\text { acentuado }\end{array}$ \\
\hline 108 & 108 LEÃO & 20 & $\mathbf{R}$ & NR & $\mathbf{R}$ & Onicogrifose \\
\hline 103 & 112 TUPÄ & 20 & 1 & NR & $R$ & Assintomático \\
\hline 103 & 113 VASCO & \multirow{2}{*}{\multicolumn{5}{|c|}{$\begin{array}{l}\text { Cães fugiram no momento da coleta e não conseguimos encontrá-los. } \\
\text { Não foi possivel retornarmos em outro momento. }\end{array}$}} \\
\hline 103 & 114 CACETE & & & & & \\
\hline 102 & 116 GINGA & \multirow{2}{*}{\multicolumn{5}{|c|}{$\begin{array}{c}\text { Os moradores não estavam na residència, na visita para coleta de sangue. } \\
\text { Não foi possivel retornarmos em outro momento. }\end{array}$}} \\
\hline 102 & 117 TIRIRICA & & & & & \\
\hline 40 & $118 \mathrm{MILLI}$ & \multicolumn{5}{|c|}{ Nảo foi possivel ir até este lote fazer a coleta de sangue. } \\
\hline 69 & 119 BALEIA & \multicolumn{5}{|r|}{ Cåo morreu. } \\
\hline 69 & 120 XEBINHA & 40 & $\mathbf{R}$ & NR & $\mathbf{R}$ & Onicogrifose \\
\hline 69 & 121 LEÄO & 40 & $\mathbf{R}$ & $\mathbf{R}$ & $\mathbf{R}$ & $\begin{array}{l}\text { Onicogrifose, lesరes de pele, emagrecimento } \\
\text { acentuado }\end{array}$ \\
\hline 69 & 123FRONTEIRA & NR & $\mathrm{R}$ & NR & $R$ & Assintomático \\
\hline
\end{tabular}

NR = Não Reagente; $R$ = Reagente; $\mid$ = Inconclusivo 
Anexo 4 - Resultados das PCR em aspirado de medula óssea e creme leucocitário e seqüenciamento, em cães do Assentamento Guaicurus, junho de 2003.

\begin{tabular}{|c|c|c|c|c|c|c|}
\hline \multirow[t]{2}{*}{ Lote } & \multirow[t]{2}{*}{ 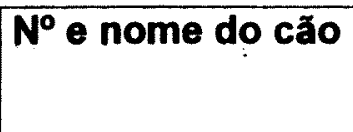 } & \multicolumn{2}{|c|}{ Aspirado de medula óssea } & \multicolumn{2}{|c|}{ Creme Leucocitário } & \multirow{2}{*}{$\begin{array}{c}\text { Sequenciamento com } \\
\mathbf{S 1 8}^{\star \star}\end{array}$} \\
\hline & & S4 / S12 & $\mathrm{S} 17 / \mathrm{S} 18$ * & $\mathbf{S 4 / S 1 2}$ & $\mathrm{s} 17 / \mathrm{S} 18$ * & \\
\hline 124 & 3 TROVÃO & Negativo & Positivo & $\begin{array}{c}\text { Positivo com bandas } \\
\text { inespecificas }\end{array}$ & Positivo & L. (L.) amazonensis \\
\hline 124 & 4 PITOCO & $\begin{array}{l}\text { Não foi } \\
\text { colhido }\end{array}$ & - & Negativo & Positivo & L. (L.) chagasi \\
\hline 122 & 5 XAROPINHO & Negativo & Negativo & $\begin{array}{l}\text { Positivo com bandas } \\
\text { inespecificas }(1: 10)\end{array}$ & Positivo & L. (L.) chagasi \\
\hline 126 & 16 CAMOIO & Negativo & Negativo & Banda muito fraca & Positivo & L. (Viannia) \\
\hline 117 & 19 DUQUE & $\begin{array}{l}\text { Não foi } \\
\text { colhido }\end{array}$ & - & Banda fraca & $\begin{array}{l}\text { Positivo com uma } \\
\text { banda inespecifica }\end{array}$ & L. (Viannia) \\
\hline 115 & 20 TEQUE & Negativo & Positivo & $\begin{array}{l}\text { Positivo com bandas } \\
\text { inespecificas }\end{array}$ & Positivo & L. (L.) amazonensis \\
\hline 16 & 25 MALHADO & Negativo & Positivo & Banda muito fraca & Positivo & L. (Viannia) \\
\hline 24 & 27 JAVANTE & Negativo & Negativo & $\begin{array}{l}\text { Positivo com bandas } \\
\text { inespecíficas }\end{array}$ & Positivo & L. (Viannia) \\
\hline 18 & 30 LULA & $\begin{array}{l}\text { Não foi } \\
\text { colhido }\end{array}$ & -2 & Negativo & Negativo & : \\
\hline 27 & 36 TARZAN & Positivo & Positivo & Banda fraca & Positivo & Leishmania (L.) chagasi \\
\hline 13 & 37 DELEGADO & Negativo & Positivo & $\begin{array}{c}\text { Positivo com bandas } \\
\text { inespecíficas }\end{array}$ & Positivo & Leishmania (L.) chagasi \\
\hline 8 & 53 DUQUESA & Negativo & Positivo & Negativo & Positivo & Leishmania (L.) chagasi \\
\hline
\end{tabular}




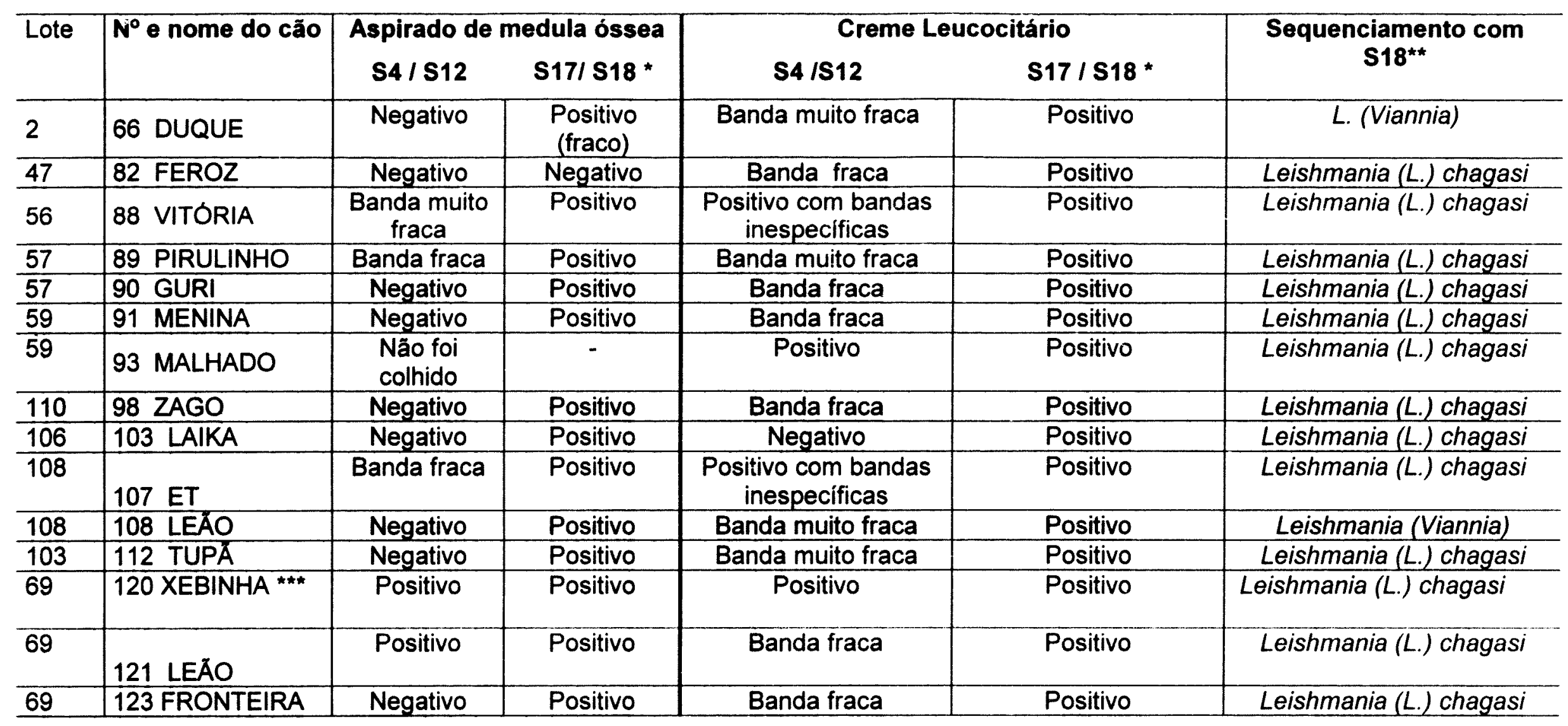

* Empregou-se o produto da PCR com os oligonucleotídeos S4 e S12

** Utilizou-se o produto da PCR com os oligonucleotídeos S17 e S18

*** O seqüenciamento do produto da PCR com S4/S12 deu Trypanosoma evansi. 
Anexo 5 - Distribuição mensal das chuvas no Município de Bonito - MS, de abril de 2002 a outubro de 2003, e da média mensal do período de 1981 a 2003.

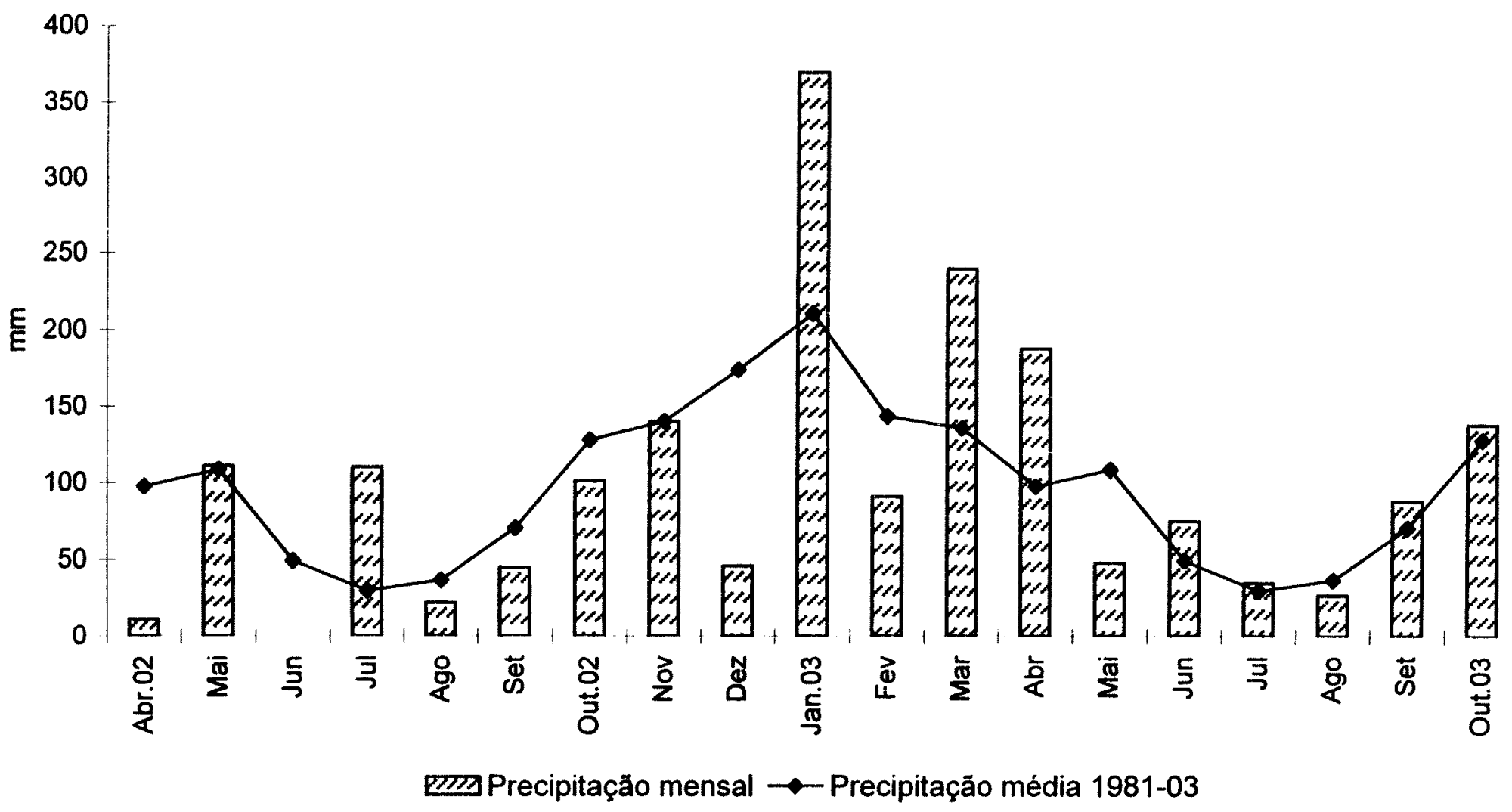


Anexo 6 - Média de Williams para fêmeas de Lu. longipalpis por local de captura no Assentamento Guaicurus, novembro de 2002 a outubro de 2003.

\begin{tabular}{|c|c|c|c|c|c|c|c|c|c|c|c|c|}
\hline Local & Novembro & Dezembro & Janeiro & Fevereiro & $\begin{array}{l}\text { Meses } \\
\text { Marco }\end{array}$ & Abril & Maio & Junho & Julho & Agosto & Setembro & Outubro \\
\hline L 02 - casa & 0,0 & 0,0 & 0,0 & 0,0 & 0,0 & 0,0 & 0,0 & 0,0 & 0,0 & 0,0 & 0,0 & 0,0 \\
\hline L 02 - mata & 0,0 & 0,0 & 0,0 & 0,0 & 0,0 & 3,1 & 0,0 & 0,0 & 0,0 & 0,0 & 0,0 & 0,0 \\
\hline L 02 - peridomicilio & 7,0 & 1,0 & 3,9 & 1,0 & 0,0 & 0,0 & 0,0 & 0,0 & 0,0 & 0,0 & 0,0 & 0,0 \\
\hline L 19 - casa & 1,0 & 0,0 & 0,0 & 0,7 & 0,4 & 2,5 & 0,0 & 0,0 & 1,7 & 0,0 & 0,4 & 0,0 \\
\hline L 19 - mata & 2,0 & 14,0 & 0,7 & 0,7 & 0,7 & 0,0 & 0,0 & 0,0 & 4,7 & 0,7 & 0,7 & 0,7 \\
\hline L 19 - peridomicilio & 0,0 & 171,2 & 4,8 & 807,2 & 69,2 & 99,2 & 2,5 & 223,9 & 10,2 & 6,8 & 0,0 & 3,6 \\
\hline L 20 - casa & 0,0 & 0,0 & 0,0 & 2,5 & 0,0 & 1,0 & 0,0 & 2,5 & 4,2 & 0,4 & 0,0 & 0,0 \\
\hline L 20 - cultivo & 0,0 & 0,0 & 0,4 & 1,7 & 0,0 & 0,0 & 0,0 & 0,0 & 5,3 & 0,0 & 0,4 & 0,0 \\
\hline L 20 - mata & 1,0 & 1,0 & 0,4 & 20,2 & 1,0 & 0,0 & 0,4 & 5,0 & 10,8 & 0,7 & 1,0 & 0,4 \\
\hline L 20 - peridomicilio & 8,0 & 0,0 & 0,0 & 0,0 & 0,0 & 0,0 & 0,0 & 0,0 & 3,8 & 1,0 & 0,0 & 0,0 \\
\hline L 35 - casa & 1,0 & 0,0 & 0,0 & 0,0 & 0,0 & 0,0 & 0,0 & 0,0 & 0,0 & 0,0 & 0,0 & 0,0 \\
\hline L 35 - peridomicilio & 0,0 & 0,0 & 0,0 & 0,0 & 0,0 & 0,0 & 0,0 & 0,0 & 0,0 & 0,0 & 0,0 & 0,0 \\
\hline L 56 - gruta & 0,0 & 0,0 & 0,0 & 0,0 & 0,0 & 0,0 & 0,0 & 0,0 & 0,0 & 0,0 & 0,0 & 0,0 \\
\hline L 59 - casa & 2,0 & 0,0 & 0,0 & 0,0 & 0,4 & 0,0 & 0,0 & 0,0 & 0,0 & 0,0 & 0,4 & 0,0 \\
\hline L 59 - peridomicilio & 0,0 & 0,0 & 0,0 & 0,0 & 0,0 & 0,0 & 0,0 & 0,0 & 0,0 & 0,0 & 0,0 & 0,0 \\
\hline L 102 - casa & 1,0 & 0,0 & 0,0 & 0,7 & 0,4 & 0,0 & 0,0 & 0,0 & 0,0 & 0,0 & 0,0 & 0,0 \\
\hline L 102 - peridomicllio & 0,0 & 0,0 & 0,0 & 0,0 & 0,4 & 0,0 & 0,0 & 0,0 & 0,0 & 0,0 & 0,0 & 0,0 \\
\hline L 110 - peridomicllio & 0,0 & 7,0 & 0,7 & 0,4 & 0,0 & 0,0 & 0,0 & 0,0 & 0,0 & 0,0 & 0,4 & 0,0 \\
\hline L 110 - cultivo & 0,0 & 2,0 & 0,4 & 0,0 & 0,0 & 0,0 & 0,0 & 0,0 & 0,0 & 0,0 & 0,0 & 0,0 \\
\hline L 110 - casa & 1,0 & 5,0 & 1,5 & 0,4 & 0,0 & 0,0 & 0,0 & 0,0 & 0,0 & 0,0 & 0,0 & 0,4 \\
\hline L 124 - casa & 0,0 & 0,0 & 0,4 & 0,4 & 0,0 & 0,4 & 0,0 & 0,0 & 0,0 & 0,0 & 0,0 & 0,0 \\
\hline L 124 - mata & 1,0 & 16,0 & 10,6 & 19,1 & 11,9 & 2,0 & 0,4 & 2,2 & 2,3 & 0,4 & 2,5 & 0,0 \\
\hline L 124 - peridomicilio & 0,0 & 2,0 & 0,0 & 4,1 & 0,4 & 0,0 & 0,0 & 0,0 & 0,7 & 0,0 & 0,4 & 0,0 \\
\hline Sede - Casa & 0,0 & 0,0 & 0,0 & 0,0 & 0,0 & 0,0 & 0,0 & 0,0 & 0,0 & 0,0 & 0,0 & 0,0 \\
\hline Sede - peridomicllio & 0,0 & 0,0 & 0,0 & 0,0 & 0,0 & 0,0 & 0,0 & 0,0 & 0,0 & 0,0 & 0,0 & 0,0 \\
\hline
\end{tabular}

L $=$ Lote 
Anexo 7 - Média de Williams para machos de Lu. Iongipalpis por local de captura no Assentamento Guaicurus, novembro de 2002 a outubro de 2003.

\begin{tabular}{|c|c|c|c|c|c|c|c|c|c|c|c|c|}
\hline \multirow[b]{2}{*}{ Local } & \multirow[b]{2}{*}{ Novembro } & \multirow[b]{2}{*}{ Dezembro } & \multirow[b]{2}{*}{ Janeiro } & \multirow[b]{2}{*}{ Fevereiro } & \multicolumn{2}{|c|}{ Meses } & \multirow[b]{2}{*}{ Maio } & \multirow[b]{2}{*}{ Junho } & \multirow[b]{2}{*}{ Julho } & \multirow[b]{2}{*}{ Agosto } & \multirow[b]{2}{*}{ Setembro } & \multirow[b]{2}{*}{ Outubro } \\
\hline & & & & & Março & Abril & & & & & & \\
\hline L02 - casa & 2,0 & 0,0 & 0,0 & 0,4 & 0,0 & 0,4 & 0,0 & 0,0 & 0,0 & 0,0 & 0,0 & 0,0 \\
\hline L 02 - mata & 2,0 & 0,0 & 0,0 & 0,0 & 0,0 & 4,3 & 0,0 & 0,0 & 0,0 & 0,0 & 0,7 & 0,0 \\
\hline L 02 - peridomicllio & 11,0 & 14,0 & 3,6 & 0,0 & 0,0 & 0,0 & 0,0 & 0,0 & 0,0 & 0,4 & 0,0 & 0,0 \\
\hline L 19 - casa & 1,0 & 0,0 & 0,4 & 1,8 & 0,4 & 0,4 & 0,0 & 0,4 & 2,5 & 1,0 & 0,4 & 0,0 \\
\hline L 19 - mata & 4,0 & 40,0 & 2,5 & 0,0 & 1,0 & 2,0 & 0,0 & 0,0 & 28,3 & 2,2 & 1,0 & 1,2 \\
\hline L 19 - peridomicllio & 0,0 & 286,7 & 15,9 & 566,5 & 297,5 & 228,1 & 1,2 & 571,8 & 16,5 & 27,1 & 0,0 & 0,0 \\
\hline L 20 - casa & 0,0 & 1,0 & 0,0 & 0,0 & 0,7 & 0,4 & 0,0 & 1,7 & 7,6 & 2,5 & 0,4 & 0,7 \\
\hline L 20 - cultivo & 1,0 & 0,0 & 0,0 & 2,5 & 0,0 & 0,0 & 0,0 & 0,0 & 8,5 & 1,0 & 1,5 & 0,0 \\
\hline L 20 - mata & 4,0 & 4,0 & 0,4 & 23,5 & 2,3 & 11,3 & 0,4 & 6,3 & 20,8 & 1,2 & 0,0 & 1,0 \\
\hline L 20 - peridomicilio & 14,0 & 1,0 & 0,0 & 0,4 & 0,0 & 0,0 & 0,0 & 0,0 & 8,5 & 1,8 & 0,0 & 0,0 \\
\hline L 35 - casa & 1,0 & 2,0 & 0,0 & 0,0 & 0,0 & 0,0 & 0,0 & 0,0 & 0,0 & 0,0 & 0,4 & 0,0 \\
\hline L 35 - peridomicilio & 0,0 & 0,0 & 0,0 & 0,0 & 0,0 & 0,0 & 0,0 & 0,0 & 0,0 & 0,0 & 0,0 & 1,2 \\
\hline L 56 - gruta & 0,0 & 0,0 & 0,0 & 0,0 & 0,0 & 0,0 & 0,0 & 0,0 & 0,0 & 0,0 & 0,0 & 0,0 \\
\hline L 59 - casa & 6,0 & 0,0 & 0,0 & 1,0 & 1,2 & 0,4 & 0,7 & 0,0 & 0,0 & 0,0 & 0,0 & 0,7 \\
\hline L 59 - peridomicilio & 0,0 & 0,0 & 0,0 & 0,0 & 0,0 & 0,0 & 0,0 & 0,0 & 0,0 & 0,0 & 0,0 & 0,7 \\
\hline L 102 - casa & 2,0 & 0,0 & 0,4 & 0,0 & 0,7 & 0,0 & 0,0 & 0,0 & 0,4 & 0,0 & 0,0 & 0,0 \\
\hline L 102 - peridomicílio & 0,0 & 0,0 & 0,0 & 0,0 & 0,0 & 0,4 & 0,0 & 0,0 & 0,0 & 0,0 & 0,0 & 0,0 \\
\hline L 110 - peridomicilio & 0,0 & 21,0 & 0,4 & 0,0 & 0,0 & 0,0 & 0,0 & 0,0 & 0,0 & 0,0 & 1,8 & 0,4 \\
\hline L 110 - cultivo & 0,0 & 3,0 & 0,0 & 0,0 & 0,0 & 0,0 & 0,0 & 0,0 & 0,0 & 0,0 & 0,0 & 0,0 \\
\hline L 110 - casa & 0,0 & 36,0 & 2,7 & 0,0 & 0,4 & 0,0 & 0,0 & 0,0 & 0,4 & 0,0 & 0,0 & 0,0 \\
\hline L 124 - casa & 1,0 & 1,0 & 0,4 & 0,0 & 0,0 & 0,0 & 1,5 & 0,0 & 0,0 & 0,0 & 0,0 & 0,0 \\
\hline L 124 - mata & 9,0 & 11,0 & 26,3 & 22,0 & 33,4 & 3,0 & 0,7 & 8,0 & 6,4 & 1,8 & 4,7 & 0,4 \\
\hline L 124 - peridomicílio & 0,0 & 5,0 & 0,4 & 8,9 & 0,0 & 0,0 & 0,4 & 0,0 & 1,2 & 0,0 & 1,0 & 0,0 \\
\hline Sede - casa & 0,0 & 0,0 & 0,0 & 0,0 & 0,0 & 0,0 & 0,0 & 0,0 & 0,0 & 0,0 & 0,0 & 0,0 \\
\hline Sede - peridomicilio & 0,0 & 0,0 & 0,0 & 0,0 & 0,0 & 0,0 & 0,0 & 0,0 & 0,0 & 0,0 & 0,0 & 0,0 \\
\hline
\end{tabular}


Anexo 8 - Média de Williams para fêmeas de Lu. almerioi por local de captura no Assentamento Guaicurus, novembro de 2002 a outubro de 2003.

\begin{tabular}{|c|c|c|c|c|c|c|c|c|c|c|c|c|}
\hline \multirow[b]{2}{*}{ Local } & \multirow[b]{2}{*}{ Novembro } & \multirow[b]{2}{*}{ Dezembro } & \multirow[b]{2}{*}{ Janeiro } & \multirow[b]{2}{*}{ Fevereiro } & \multirow[b]{2}{*}{ Marco } & \multicolumn{3}{|c|}{ Meses } & \multirow[b]{2}{*}{ Julho } & \multirow[b]{2}{*}{ Agosto } & \multirow[b]{2}{*}{ Setembro } & \multirow[b]{2}{*}{ Outubro } \\
\hline & & & & & & Abril & Maio & Junho & & & & \\
\hline$\overline{\mathrm{L} 02-\mathrm{casa}}$ & 0,0 & 0,0 & 0,0 & 0,0 & 0,0 & 0,0 & 0,0 & 0,0 & 0,0 & 0,0 & 0,0 & 0,0 \\
\hline L 02 - mata & 0,0 & 0,0 & 0,0 & 0,0 & 0.0 & 0,4 & 0,0 & 0,0 & 0,0 & 0,0 & 0,0 & 0,0 \\
\hline L 02 - peridomicllio & 0,0 & 0,0 & 0,0 & 0,7 & 0,0 & 0,0 & 0,0 & 0,0 & 0,0 & 0,0 & 0,0 & 0,0 \\
\hline L 19 - casa & 0,0 & 0,0 & 0,0 & 0,0 & 0,0 & 0,7 & 0,0 & 0,0 & 0,0 & 0,0 & 0,0 & 0,0 \\
\hline L 19 - mata & 3,0 & 5,0 & 0,0 & 0,0 & 0,0 & 0,0 & 0,0 & 0,0 & 2,0 & 0,4 & 0,4 & 0,0 \\
\hline L 19 - peridomicilio & 0,0 & 63,0 & 0,0 & 63,4 & 3,9 & 5,3 & 0,4 & 20,0 & 4,9 & 6,3 & 0,0 & 14,5 \\
\hline L 20 - casa & 0,0 & 1,0 & 0,0 & 1,8 & 0,0 & 0,0 & 0,0 & 0,0 & 0,0 & 0,0 & 0,7 & 0,0 \\
\hline L 20 - cultivo & 0,0 & 0,0 & 0,0 & 0,4 & 0,0 & 0,0 & 0,0 & 0,0 & 0,4 & 0,0 & 0,0 & 0,0 \\
\hline L 20 - mata & 2,0 & 23,0 & 8,0 & 49,5 & 0,4 & 0,7 & 0,0 & 1,8 & 4,8 & 3,1 & 1,5 & 0,0 \\
\hline L 20 - peridomicllio & 3,0 & 5,0 & 0,0 & 1,8 & 0,0 & 0,0 & 0,0 & 0,4 & 1,0 & 0,7 & 1,0 & 0,0 \\
\hline L 35 - casa & 0,0 & 0,0 & 0,0 & 0,0 & 0,0 & 0,0 & 0,0 & 0,0 & 0,0 & 0,0 & 0,0 & 0,0 \\
\hline L 35 - peridomicllio & 0,0 & 0,0 & 0,0 & 0,0 & 0,0 & 0,0 & 0,0 & 0,0 & 0,0 & 0,0 & 0,0 & 0,0 \\
\hline L 56 - gruta & 5,0 & 14,0 & 6,5 & 41,2 & 4,7 & 2,3 & 0,0 & 2,3 & 1,5 & 0,0 & 0,4 & 8,2 \\
\hline L 59 - casa & 0,0 & 0,0 & 0,0 & 0,0 & 0,0 & 0,4 & 0,0 & 0,4 & 0,0 & 0,0 & 0,4 & 0,0 \\
\hline L 59 - peridomicilio & 0,0 & 1,0 & 0,0 & 0,4 & 0,0 & 0,0 & 0,0 & 0,0 & 0,0 & 0,0 & 0,0 & 0,0 \\
\hline L 102 - casa & 0,0 & 0,0 & 0,0 & 0,0 & 0,0 & 0,0 & 0,0 & 0,0 & 0,0 & 0,0 & 0,0 & 0,0 \\
\hline L 102 - peridomicilio & 0,0 & 0,0 & 0,0 & 0,0 & 0,0 & 0,0 & 0,0 & 0,0 & 0,0 & 0,0 & 0,0 & 0,0 \\
\hline L 110 - peridomicilio & 0,0 & 0,0 & 0,0 & 0,0 & 0,4 & 0,0 & 0,0 & 0,0 & 0,0 & 0,0 & 0,0 & 0,0 \\
\hline L 110 - cultivo & 0,0 & 0,0 & 0,0 & 0,0 & 0,0 & 0,0 & 0,0 & 0,0 & 0,0 & 0,0 & 0,0 & 0,0 \\
\hline L 110 - casa & 0,0 & 0,0 & 0,0 & 0,0 & 0,0 & 0,0 & 0,0 & 0,0 & 0,0 & 0,0 & 0,0 & 0,0 \\
\hline L 124 - casa & 0,0 & 0,0 & 0,0 & 0,0 & 0,0 & 0,0 & 0,0 & 0,0 & 0,0 & 0,0 & 0,0 & 0,0 \\
\hline L 124 - mata & 0,0 & 1,0 & 0,4 & 2,5 & 0,0 & 0,0 & 0,0 & 0,0 & 0,4 & 0,0 & 0,0 & 0,0 \\
\hline L 124 - peridomicilio & 0,0 & 0,0 & 0,0 & 0,4 & 0,0 & 0,0 & 0,0 & 0,0 & 0,0 & 0,0 & 0,0 & 0,0 \\
\hline Sede - casa & 0,0 & 0,0 & 0,0 & 0,0 & 0,0 & 0,0 & 0,0 & 0,0 & 0,0 & 0,0 & 0,0 & 0,0 \\
\hline Sede - peridomicilio & 0,0 & 0,0 & 0,0 & 0,0 & 0,0 & 0,0 & 0,0 & 0,0 & 0,0 & 0,0 & 0,0 & 0,0 \\
\hline
\end{tabular}


Anexo 9 - Média de Williams para machos de Lu. almerioi por local de captura no Assentamento Guaicurus, novembro de 2002 a outubro de 2003.

\begin{tabular}{|c|c|c|c|c|c|c|c|c|c|c|c|c|}
\hline \multirow[b]{2}{*}{ Local } & \multirow[b]{2}{*}{ Novembro } & \multirow[b]{2}{*}{ Dezembro } & \multirow[b]{2}{*}{ Janeiro } & \multirow[b]{2}{*}{ Fevereiro } & \multicolumn{2}{|c|}{ Meses } & \multirow[b]{2}{*}{ Maio } & \multirow[b]{2}{*}{ Junho } & \multirow[b]{2}{*}{ Julho } & \multirow[b]{2}{*}{ Agosto } & \multirow[b]{2}{*}{ Setembro } & \multirow[b]{2}{*}{ Outubro } \\
\hline & & & & & Março & Abril & & & & & & \\
\hline L 02 - casa & 0,0 & 0,0 & 0,0 & 0,0 & 0,0 & 0,0 & 0,0 & 0,0 & 0,0 & 0,0 & 0,0 & 0,0 \\
\hline L 02 - mata & 0,0 & 0,0 & 0,0 & 0,0 & 0,0 & 0,7 & 0,0 & 0,0 & 0,0 & 0,0 & 0,0 & 0,0 \\
\hline L 02 - peridomicilio & 0,0 & 0,0 & 0,0 & 0,0 & 0,0 & 0,0 & 0,0 & 0,0 & 0,0 & 0,0 & 0,0 & 0,0 \\
\hline L 19 - casa & 0,0 & 0,0 & 0,0 & 0,0 & 0,0 & 0,0 & 0,0 & 0,0 & 0,0 & 0,0 & 0,0 & 0,0 \\
\hline L 19 - mata & 0,0 & 2,0 & 0,4 & 0,4 & 0,0 & 0,0 & 0,0 & 0,0 & 1,0 & 0,0 & 0,4 & 0,4 \\
\hline L 19 - peridomicllio & 0,0 & 3,0 & 0,0 & 2,2 & 0,4 & 0,4 & 0,0 & 5,3 & 1,0 & 2,9 & 0,0 & 0,0 \\
\hline L 20 - casa & 0,0 & 1,0 & 0,0 & 0,0 & 0,0 & 0,0 & 0,0 & 0,4 & 0,4 & 0,0 & 0,0 & 0,0 \\
\hline L 20 - cultivo & 0,0 & 0,0 & 0,0 & 0,0 & 0,0 & 0,0 & 0,0 & 0,0 & 0,0 & 0,0 & 0,4 & 0,0 \\
\hline L 20 - mata & 6,0 & 12,0 & 1,5 & 11,0 & 0,7 & 0,4 & 0,0 & 0,7 & 2,7 & 4,0 & 0,0 & 0,4 \\
\hline L 20 - peridomicllio & 0,0 & 5,0 & 0,0 & 0,7 & 0,0 & 0,0 & 0,0 & 0,0 & 0,4 & 0,0 & 0,0 & 0,0 \\
\hline L 35 - casa & 0,0 & 0,0 & 0,0 & 0,0 & 0,0 & 0,0 & 0,0 & 0,0 & 0,0 & 0,0 & 0,0 & 0,0 \\
\hline L 35 - peridomicillio & 0,0 & 0,0 & 0,0 & 0,0 & 0,0 & 0,0 & 0,0 & 0,0 & 0,0 & 0,0 & 0,0 & 0,4 \\
\hline L 56 - gruta & 1,0 & 8,0 & 4,1 & 13,5 & 4,1 & 1,5 & 1,7 & 1,8 & 0,4 & 1,8 & 0,7 & 1,8 \\
\hline L 59 - casa & 0,0 & 0,0 & 0,0 & 0,4 & 0,0 & 0,0 & 0,0 & 0,0 & 0,0 & 0,0 & 0,7 & 0,4 \\
\hline L 59 - peridomicilio & 0,0 & 0,0 & 0,0 & 0,0 & 0,0 & 0,0 & 0,0 & 0,0 & 0,0 & 0,0 & 0,0 & 0,0 \\
\hline L 102 - casa & 0,0 & 0,0 & 0,0 & 0,0 & 0,0 & 0,0 & 0,0 & 0,0 & 0,0 & 0,0 & 0,0 & 0,0 \\
\hline L 102 - peridomicilio & 0,0 & 0,0 & 0,0 & 0,0 & 0,0 & 0,0 & 0,0 & 0,0 & 0,0 & 0,0 & 0,0 & 0,0 \\
\hline L 110 - peridomicilio & 0,0 & 0,0 & 0,0 & 0,0 & 0,0 & 0,0 & 0,0 & 0,0 & 0,0 & 0,0 & 0,0 & 0,0 \\
\hline L 110 - cultivo & 0,0 & 1,0 & 0,0 & 0,0 & 0,0 & 0,0 & 0,0 & 0,0 & 0,0 & 0,0 & 0,0 & 0,0 \\
\hline L 110 - casa & 0,0 & 0,0 & 0,0 & 0,0 & 0,0 & 0,0 & 0,0 & 0,0 & 0,0 & 0,0 & 0,0 & 0,0 \\
\hline L 124 - casa & 0,0 & 0,0 & 0,0 & 0,0 & 0,0 & 0,0 & 0,0 & 0,0 & 0,0 & 0,0 & 0,0 & 0,0 \\
\hline L 124 - mata & 0,0 & 3,0 & 1,0 & 1,5 & 1,0 & 0,4 & 0,0 & 0,0 & 0,0 & 0,0 & 0,0 & 0,0 \\
\hline L 124 - peridomicílio & 0,0 & 0,0 & 0,0 & 0,7 & 0,0 & 0,0 & 0,0 & 0,0 & 0,0 & 0,0 & 0,0 & 0,0 \\
\hline Sede - casa & 0,0 & 0,0 & 0,0 & 0,0 & 0,0 & 0,0 & 0,0 & 0,0 & 0,0 & 0,0 & 0,0 & 0,0 \\
\hline Sede - peridomicilio & 0,0 & 0,0 & 0,0 & 0,0 & 0,0 & 0,0 & 0,0 & 0,0 & 0,0 & 0,0 & 0,0 & 0,0 \\
\hline
\end{tabular}

$\mathrm{L}=$ Lote 
Anexo 10 - Média de Williams para fêmeas de $\mathbf{N y}$. whitmani por local de captura no Assentamento Guaicurus, novembro de 2002 a outubro de 2003.

\begin{tabular}{|c|c|c|c|c|c|c|c|c|c|c|c|c|}
\hline \multirow[b]{2}{*}{ Local } & \multirow[b]{2}{*}{ Novembro } & \multirow[b]{2}{*}{ Dezembro } & \multirow[b]{2}{*}{ Janeiro } & \multirow[b]{2}{*}{ Fevereiro } & \multicolumn{2}{|c|}{ Meses } & \multirow[b]{2}{*}{ Maio } & \multirow[b]{2}{*}{ Junho } & \multirow[b]{2}{*}{ Julho } & \multirow[b]{2}{*}{ Agosto } & \multirow[b]{2}{*}{ Setembro } & \multirow[b]{2}{*}{ Outubro } \\
\hline & & & & & Março & Abril & & & & & & \\
\hline L 02 - casa & 0,0 & 0,0 & 0,0 & 0,0 & 0,0 & 0,0 & 0,0 & 0,0 & 0,0 & 0,0 & 0,0 & 0,0 \\
\hline L 02 - mata & 0,0 & 0,0 & 0,0 & 0,0 & 0,4 & 0,7 & 0,0 & 0,0 & 0,0 & 0,0 & 0,0 & 0,0 \\
\hline L 02 - peridomicilio & 0,0 & 0,0 & 0,0 & 0,0 & 0,0 & 0,0 & 0,0 & 0,0 & 0,4 & 0,0 & 0,0 & 0,0 \\
\hline L 19 - casa & 0,0 & 0,0 & 0,0 & 0,0 & 0,0 & 0,0 & 0,0 & 0,0 & 0,0 & 0,0 & 0,0 & 0,0 \\
\hline L 19 - mata & 0,0 & 0,0 & 0,0 & 0,0 & 0,0 & 0,0 & 0,0 & 0,0 & 0,7 & 0,0 & 0,0 & 0,0 \\
\hline L 19 - peridomicllio & 0,0 & 0,0 & 0,0 & 7,4 & 6,4 & 6,4 & 0,0 & 14,2 & 0,0 & 1,0 & 0,0 & 0,0 \\
\hline L 20 - casa & 0,0 & 0,0 & 0,0 & 0,0 & 0,0 & 0,0 & 0,0 & 0,0 & 0,0 & 0,0 & 0,0 & 0,0 \\
\hline L 20 - cultivo & 0,0 & 0,0 & 0,0 & 0,0 & 0,0 & 0,0 & 0,0 & 0,0 & 0,4 & 0,4 & 0,0 & 0,0 \\
\hline L 20 - mata & 0,0 & 0,0 & 0,0 & 0,0 & 0,0 & 1,5 & 0,0 & 0,0 & 2,3 & 0,0 & 0,0 & 0,0 \\
\hline L 20 - peridomicllio & 0,0 & 0,0 & 0,0 & 0,0 & 0,0 & 0,0 & 0,0 & 0,0 & 1,2 & 0,7 & 0,0 & 0,0 \\
\hline L 35 - casa & 0,0 & 0,0 & 0,0 & 0,0 & 0,0 & 0,0 & 0,0 & 0,0 & 0,0 & 0,0 & 0,0 & 0,0 \\
\hline L 35 - peridomicilio & 0,0 & 0,0 & 0,0 & 0,0 & 0,0 & 0,0 & 0,0 & 0,0 & 0,0 & 0,0 & 0,0 & 0,0 \\
\hline L 56 - gruta & 0,0 & 0,0 & 0,0 & 0,0 & 0,0 & 0,0 & 0,0 & 0,0 & 0,0 & 0,0 & 0,0 & 0,0 \\
\hline L 59 - casa & 0,0 & 0,0 & 0,0 & 0,0 & 0,0 & 0,0 & 0,0 & 0,0 & 0,0 & 0,0 & 0,0 & 0,0 \\
\hline L 59 - peridomicilio & 0,0 & 0,0 & 0,0 & 0,0 & 0,4 & 0,0 & 0,0 & 0,0 & 0,0 & 0,0 & 0,0 & 0,0 \\
\hline L 102 - casa & 0,0 & 0,0 & 0,0 & 0,0 & 0,0 & 0,0 & 0,0 & 0,0 & 0,0 & 0,0 & 0,4 & 0,0 \\
\hline L 102 - peridomicílio & 0,0 & 0,0 & 0,0 & 0,0 & 0,0 & 0,0 & 0,0 & 0,0 & 0,0 & 0,0 & 0,0 & 0,0 \\
\hline L 110 - peridomicílio & 0,0 & 0,0 & 0,0 & 0,0 & 0,0 & 0,0 & 0,0 & 0,0 & 0,0 & 0,0 & 0,0 & 0,0 \\
\hline L 110 - cultivo & 0,0 & 0,0 & 0,0 & 0,0 & 0,0 & 0,0 & 0,0 & 0,0 & 0,0 & 0,0 & 0,0 & 0,0 \\
\hline L 110 - casa & 0,0 & 1,0 & 0,0 & 0,0 & 0,0 & 0,0 & 0,0 & 0,0 & 0,0 & 0,0 & 0,0 & 0,0 \\
\hline L 124 - casa & 0,0 & 0,0 & 0,0 & 0,0 & 0,0 & 0,0 & 0,0 & 0,0 & 0,0 & 0,0 & 0,0 & 0,0 \\
\hline L 124 - mata & 0,0 & 0,0 & 0,0 & 0,4 & 1,0 & 0,0 & 0,0 & 0,0 & 0,0 & 0,0 & 0,0 & 0,0 \\
\hline L 124 - peridomicilio & 0,0 & 0,0 & 0,0 & 0,4 & 0,0 & 0,0 & 0,0 & 0,0 & 0,0 & 0,0 & 0,0 & 0,0 \\
\hline Sede - casa & 0,0 & 0,0 & 0,0 & 0,0 & 0,0 & 0,0 & 0,0 & 0,0 & 0,0 & 0,4 & 0,0 & 0,0 \\
\hline Sede - peridomicilio & 0,0 & 0,0 & 0,0 & 0,0 & 0,0 & 0,0 & 0,0 & 0,0 & 0,0 & 0,0 & 0,0 & 0,0 \\
\hline
\end{tabular}

$L=$ Lote 
Anexo 11 - Média de Williams para machos de Ny. whitmani por local de captura no Assentamento Guaicurus, novembro de 2002 a outubro de 2003

\begin{tabular}{|c|c|c|c|c|c|c|c|c|c|c|c|c|}
\hline \multirow[b]{2}{*}{ Local } & \multirow[b]{2}{*}{ Novembro } & \multirow[b]{2}{*}{ Dezembro } & \multirow[b]{2}{*}{ Janeiro } & \multirow[b]{2}{*}{ Fevereiro } & \multicolumn{2}{|c|}{ Meses } & \multirow[b]{2}{*}{ Maio } & \multirow[b]{2}{*}{ Junho } & \multirow[b]{2}{*}{ Julho } & \multirow[b]{2}{*}{ Agosto } & \multirow[b]{2}{*}{ Setembro } & \multirow[b]{2}{*}{ Outubro } \\
\hline & & & & & Março & Abril & & & & & & \\
\hline L 02 - casa & 0,0 & 0,0 & 0,0 & 0,0 & 0,0 & 0,0 & 0,0 & 0,0 & 0,0 & 0,0 & 0,0 & 0,0 \\
\hline L 02 - mata & 0,0 & 0,0 & 0,0 & 0,0 & 0,0 & 0,4 & 0,0 & 0,0 & 0,0 & 0,0 & 0,0 & 0,0 \\
\hline L 02 - peridomicilio & 0,0 & 0,0 & 0,0 & 0,4 & 0,0 & 0,0 & 0,0 & 0,0 & 0,0 & 0,4 & 0,0 & 0,0 \\
\hline L 19 - casa & 0,0 & 0,0 & 0,0 & 0,0 & 0,0 & 0,0 & 0,0 & 0,0 & 0,4 & 0,0 & 0,0 & 0,0 \\
\hline L 19 - mata & 0,0 & 0,0 & 0,0 & 0,0 & 0,0 & 0,0 & 0,0 & 0,0 & 1,8 & 0,4 & 0,0 & 0,0 \\
\hline L 19 - peridomicilio & 0,0 & 0,0 & 0,7 & 17,3 & 6,1 & 14,5 & 0,0 & 55,5 & 5,2 & 0,7 & 0,0 & 0,0 \\
\hline L 20 - casa & 0,0 & 0,0 & 0,0 & 0,0 & 0,0 & 0,0 & 0,0 & 0,0 & 0,0 & 0,0 & 0,0 & 0,0 \\
\hline L 20 - cultivo & 0,0 & 0,0 & 0,0 & 0,4 & 0,0 & 0,0 & 0,0 & 0,0 & 1,2 & 0,0 & 0,0 & 0,0 \\
\hline L 20 - mata & 0,0 & 0,0 & 0,0 & 0,0 & 0,0 & 0,0 & 0,0 & 0,0 & 5,4 & 0,4 & 0,0 & 0,0 \\
\hline L 20 - peridomicilio & 1,0 & 0,0 & 0,0 & 0,0 & 0,0 & 0,0 & 0,0 & 0,0 & 2,3 & 0,0 & 0,0 & 0,0 \\
\hline L 35 - casa & 0,0 & 0,0 & 0,0 & 0,0 & 0,0 & 0,0 & 0,0 & 0,0 & 0,0 & 0,0 & 0,0 & 0,0 \\
\hline L 35 - peridomicilio & 0,0 & 0,0 & 0,0 & 0,0 & 0,0 & 0,0 & 0.0 & 0,0 & 0,0 & 0,0 & 0,0 & 0,0 \\
\hline L 56 - gruta & 0,0 & 0,0 & 0,0 & 0,0 & 0,0 & 0,0 & 0,0 & 0,0 & 0,0 & 0,0 & 0,0 & 0,0 \\
\hline L 59 - casa & 0,0 & 0,0 & 0,0 & 0,0 & 0,0 & 0,0 & 0,0 & 0,0 & 0,0 & 0,0 & 0,0 & 0,0 \\
\hline L 59 - peridomicllio & 0,0 & 0,0 & 0,0 & 0,0 & 0,0 & 0,0 & 0,0 & 0,4 & 0,0 & 0,0 & 0,0 & 0,0 \\
\hline L 102 - casa & 0,0 & 0,0 & 0,0 & 0,0 & 0,4 & 0,0 & 0,0 & 0,0 & 0,0 & 0,0 & 0,0 & 0,0 \\
\hline L 102 - peridomicilio & 0,0 & 0,0 & 0,0 & 0,0 & 0,0 & 0,0 & 0,0 & 0,0 & 0,0 & 0,0 & 0,0 & 0,0 \\
\hline L 110 - peridomićllio & 0,0 & 0,0 & 0,0 & 0,0 & 0,0 & 0,0 & 0,0 & 0,0 & 0,0 & 0,0 & 0,0 & 0,0 \\
\hline L 110 - cultivo & 0,0 & 0,0 & 0,0 & 0,0 & 0,0 & 0,0 & 0,0 & 0,0 & 0,0 & 0,0 & 0,0 & 0,0 \\
\hline L 110 - casa & 0,0 & 0,0 & 0,0 & 0,0 & 0,0 & 0,0 & 0,0 & 0,0 & 0,0 & 0,0 & 0,0 & 0,0 \\
\hline L 124 - casa & 0,0 & 0,0 & 0,0 & 0,0 & 0,0 & 0,0 & 0,0 & 0,0 & 0,0 & 0,0 & 0,0 & 0,0 \\
\hline L 124 - mata & 0,0 & 0,0 & 0,4 & 0,4 & 1,2 & 0,0 & 0,0 & 1,5 & 1,0 & 0,0 & 0,0 & 0,0 \\
\hline L 124 - peridomicilio & 0,0 & 0,0 & 0,0 & 1,2 & 0,0 & 0,0 & 0,0 & 0,0 & 0,4 & 0,0 & 0,0 & 0,0 \\
\hline Sede - casa & 0,0 & 0,0 & 0,0 & 0,0 & 0,0 & 0,0 & 0,0 & 0,0 & 0,0 & 0,0 & 0,0 & 0,0 \\
\hline Sede - peridomicilio & 0,0 & 0,0 & 0,0 & 0,0 & 0,0 & 0,0 & 0,0 & 0,0 & 0,0 & 0,0 & 0,0 & 0,0 \\
\hline
\end{tabular}

